\title{
Merjenje zrelosti procesne usmerjenosti
}

Rajko Novak

Aleksander Janeš

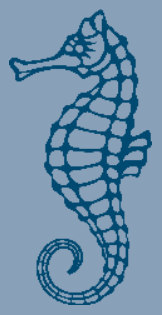


University of Primorska Press

Editorial Board

Katarina Babnik

Štefan Bojnec

Aleksandra Brezovec

Boris Horvat

Dejan Hozjan

Alenka Janko Spreizer

Alen Ježovnik

Lenka Kavčič

Alan Orbanič

Gregor Pobežin

Andraž Teršek

Jonatan Vinkler
Faculty of Management Monograph Series

Editor in Chief

Matjaž Novak

Editorial Board

Ana Arzenšek

Štefan Bojnec

Dubravka Celinšek

Armand Faganel

Viktorija Florjančič

Borut Kodrič

Suzana Laporšek

Mirko Markič

Franko Milost

Matjaž Nahtigal

Mitja Ruzzier

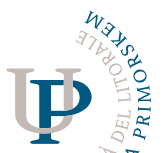

UNIVER Z 


\section{Merjenje zrelosti procesne usmerjenosti}

Rajko Novak

Aleksander Janeš

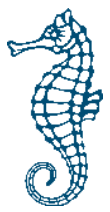


Merjenje zrelosti procesne usmerjenosti

Rajko Novak

Aleksander Janeš

Recenzenta

Boris Bukovec

Tomaž Kern

Jezikovni pregled: Davorin Dukič

Prelom in priprava za izdajo: Jonatan Vinkler

Izdala

Založba Univerze na Primorskem

(za založnika: prof. dr. Dragan Marušič, rektor)

Titov trg 4, SI-600o Koper

Glavni urednik

Jonatan Vinkler

Vodja založbe

Alen Ježovnik

Koper 2017

ISBN 978-96I-7023-55-8 (pdf)

http://www.hippocampus.si/ISBN/978-96I-7023-55-8.pdf

ISBN 978-96I-7023-56-5 (html)

http://www.hippocampus.si/ISBN/978-96I-7023-56-5/index.html

DOI: https://doi.org/I0.26493/978-96I-7023-55-8

(C) 2017 Univerza na Primorskem

Izdaja je sofinancirana po pogodbi ARRS za sofinanciranje izdajanja znanstvenih monografij v letu 2017.

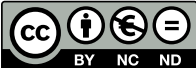

Kataložni zapis o publikaciji (CIP) pripravili v Narodni in univerzitetni knjižnici v Ljubljani

COBISS.SI-ID $=293034496$ ISBN $978-961-7023-55-8$ (pdf)

ISBN 978-96I-7023-56-5 (html) 


\section{Vsebina}

Slike • 9

\section{Preglednice - II}

\section{Krajšave $\cdot 15$}

\section{Uvod - 19}

Opredelitev raziskovalnega problema • 20

Namen in cilji raziskave • 22

Razvoj teze in hipotez $\bullet 23$

Predstavitev raziskovalnih metod • 24

Omejitve in predpostavke • 25

Uporaba pojmov in izrazoslovje • 26

\section{Poslovni procesi in procesni pristop • 27}

Poslovni procesi skozi čas • 28

Procesi v managerskih orodjih • 34

Razumevanje poslovnih procesov in definicije • 35

Procesni pristop • 37

Arhitektura poslovnih procesov $\bullet$ 4I

Vrste procesov

Določitev procesov in opredelitev elementov procesa

Vloga in naloge skrbnika procesa $\bullet 45$

Povzetek pregleda literature • 47 


\title{
Upravljanje in management poslovnih procesov $\bullet 49$
}

Upravljanje poslovnih procesov $\bullet 49$

Management poslovnih procesov $\bullet 53$

Življenjski cikel managementa poslovnih procesov • 57

Cilji in zmogljivost poslovnih procesov • 58

Nadzor in merjenje procesov • 6I

Izboljševanje in inoviranje procesov $\bullet \mathbf{6 2}$

Kaj in zakaj izboljševati $\bullet 63$

Izboljševanje procesov • 66

Inoviranje procesov $\bullet 68$

Uveljavljene metodologije izboljševanja procesov • 70

Vpliv sodobnih tehnologij in orodij • 75

Povzetek pregleda literature $\bullet 77$

\section{Procesno usmerjena organizacija $\bullet 79$}

Funkcijska usmerjenost in organiziranost $\bullet 79$

Procesna usmerjenost in delovanje organizacije $\bullet \quad 82$

Razvoj organizacijskih struktur $\bullet 86$

Razvijanje procesne usmerjenosti • 9I

Vpliv procesne usmerjenosti na uspešnost poslovanja $\bullet 92$

Povzetek pregleda literature $\bullet 93$

\section{Zrelostni modeli procesne usmerjenosti • 95}

Koncept procesne zrelosti • 97

Pregled uveljavljenih modelov zrelosti • IO5

Ocenjevanje ravni zrelosti • I07

Uporabnost zrelostnih modelov in kritike • 108

Povzetek pregleda literature • IO9

\section{Predstavitev elektroenergetske dejavnosti • III}

Elektroenergetski sistem • III

$\operatorname{Trg}$ z električno energijo • II2

Organiziranost elektroenergetske dejavnosti • II4

Proizvodnja električne energije • II4

Prenos električne energije • II5

Distribucija električne energije • II5

\author{
Merjenje zrelosti procesne usmerjenosti v elektroenergetski \\ dejavnosti • II7 \\ Kvantitativni del raziskave • II7 \\ Namen in cilji raziskave $\bullet \quad$ II 7 \\ Metode za doseganje ciljev • \\ Opis vzorca • 120 \\ Zrelost procesne usmerjenosti $\bullet$ I2I \\ Preverjanje zastavljenih hipotez $\bullet \quad$ I42
}


Primerjava zrelosti procesne usmerjenosti in poslovne uspešnosti elektrodistribucijskih organizacij • 145

Izbor relevantnih kazalnikov poslovne uspešnosti • I45

Analiza in predstavitev rezultatov • 146

\section{Sklep -149}

\section{Literatura in viri $\bullet 153$}

Literatura $\bullet 153$

Viri • 162

Priloge -165

Vprašalnik • I66

Strateški vidik • 173

Opredeljenost in dokumentiranje procesov • 174

Merjenje in management procesov -175

Procesna organizacijska struktura • 176

Upravljanje z zaposlenimi • 177

Procesna organizacijska kultura $\bullet \quad{ }_{7} 8$

Tržna usmerjenost $\bullet \quad 180$

Vidik (poslovnih partnerjev) • I8I

Procesna informacijska tehnologija $\bullet \quad 182$

Rangiranje rezultatov $\bullet$ I85

Primerjava poslovne uspešnosti in procesne usmerjenosti • I87

\section{Recenziji • I89}

I $• 189$

II - 190 



\section{Slike}

23 Slika r: Cilji in rezultati raziskave

28 Slika 2: Porterjeva veriga vrednosti

32 Slika 3: Razvoj in uveljavljanje koncepta procesov, BPM in BPMM

35 Slika 4: Procesi v managerskih orodjih

39 Slika 5: Splošne zahteve ISO 900I:2000

40 Slika 6: Shematični prikaz elementov procesa

4I Slika 7: Generična hierarhija procesov

45 Slika 8: Bistvene sestavine procesa

5I Slika 9: Odnos med upravljanjem BPM in BPM

52 Slika ro: Umeščenost upravljanja procesov v upravljanje organizacije

56 Slika Ir: Celosten pogled na BPM

58 Slika I2: Razširjen okvir BPM s poudarkom na strategiji

59 Slika ı3: Model vrzeli

63 Slika I4: BPTrends metodologija obvladovanja sprememb procesov

64 Slika 15: Ocenjevanje uspešnosti in učinkovitosti procesa

65 Slika i6: Analiza kompleksnosti in strateške pomembnosti procesa

67 Slika 17: Osnovni postopki izboljševanja procesov

70 Slika I8: Dinamika inoviranja izdelkov in procesov

8I Slika 19: Funkcijska usmerjenost in organizacijska struktura

83 Slika 20: Procesno razumevanje delovanja organizacije

85 Slika 2r: Razširjen okvir procesne usmerjenosti

86 Slika 22: Področja zmogljivosti BPM in BPO

88 Slika 23: Zvezda model organizacije

90 Slika 24: Uveljavljanje horizontalne organizacijske strukture

92 Slika 25: Točke preloma pri uveljavljanju in razvijanju procesne usmerjenosti

98 Slika 26: Ocenjevanje stanja procesa

99 Slika 27: McCormackov zrelostni model 
Merjenje zrelosti procesne usmerjenosti

Ioo Slika 28: Kako delujejo zrelostne stopnje v BPMM

IO2 Slika 29: Primerjava stopenj zmogljivosti in zrelosti CMMI

I03 Slika 30: Zrelostni model Bergholtz in Danielsson

104 Slika 31: Okvir zmogljivosti procesov in vrste zrelostnih modelov

II3 Slika 32: Model oskrbe z električno energijo

I30 Slika 33: Položaj najvišje rangiranega zaposlenega, odgovornega za procese

I50 Slika 34: Statistično ovrednotene ocene elementov procesne usmerjenosti 


\section{Preglednice}

36 Preglednica r: Primeri definicij pojma proces

54 Preglednica 2: Primeri definicij BPM

60 Preglednica 3: Področja zmogljivosti po elementih BPM

69 Preglednica 4: Značilnosti izboljševanja in inoviranja procesov

77 Preglednica 5: Potrebne transformacije poslovanja za pameten proizvodni proces

8I Preglednica 6: Osredotočenost na izdelke in osredotočenost na odjemalca

82 Preglednica 7: Značilnosti funkcijske in procesne organizacije

83 Preglednica 8: Značilnosti osredotočenosti na organizacijo oziroma na procese

I05 Preglednica 9: Izbor uveljavljenih javno dostopnih zrelostnih modelov

II9 Preglednica ıo: Statistika zanesljivosti anketnega vprašalnika

I20 Preglednica II: Demografski podatki anketiranih managerjev

I2I Preglednica I2: Demografski podatki anketiranih oseb znotraj posameznih skupin GEN, HSE in elektrodistribucijskih podjetij

I22 Preglednica I3: Procesna usmerjenost

I22 Preglednica I4: Strateški vidik

I23 Preglednica 15: KMO in Bartlettov test - strateški vidik

123 Preglednica 16: Celotna pojasnjena varianca - strateški vidik

I24 Preglednica I7: Uteži posameznih spremenljivk, vključenih v novo spremenljivko » Strateški vidik «

I24 Preglednica I8: Povprečna vrednost in standardni odklon nove spremenljivke » Strateški vidik «

I24 Preglednica 19: Glavni in podporni poslovni procesi

I25 Preglednica 20: Opredeljenost in dokumentiranje procesov

I25 Preglednica 21: KMO in Bartlettov test - opredeljenost in dokumentiranje procesov

I26 Preglednica 22: Celotna pojasnjena varianca - opredeljenost in dokumentiranje procesov 
I26 Preglednica 23: Uteži posameznih spremenljivk, vključenih v novo spremenljivko »Opredeljenost in dokumentiranje procesov $\ll$

I26 Preglednica 24: Povprečna vrednost in standardni odklon nove spremenljivke $\gg$ Opredeljenost in dokumentiranje procesov«

Preglednica 25: Merjenje in management procesov

I27 Preglednica 26: KMO in Bartlettov test merjenje in management procesov

I28 Preglednica 27: Celotna pojasnjena varianca - merjenje in management procesov

I28 Preglednica 28: Uteži posameznih spremenljivk, vključenih v novo spremenljivko $\gg$ Merjenje in management procesov $\ll$

129 Preglednica 29: Povprečna vrednost in standardni odklon nove spremenljivke $»$ Merjenje in management procesov $\ll$ Preglednica 30: Procesna organizacijska struktura

130 Preglednica 31: KMO in Bartlettov test procesna organizacijska struktura

I3I Preglednica 32: Celotna pojasnjena varianca - procesna organizacijska struktura procesne organizacijske strukture

Preglednica 34: Povprečna vrednost in standardni odklon nove spremenljivke »Procesna organizacijska struktura «

132 Preglednica 35: Upravljanje z zaposlenimi

132 Preglednica 36: KMO in Bartlettov test upravljanje z zaposlenimi

133 Preglednica 37: Celotna pojasnjena varianca - upravljanje z zaposlenimi

133 Preglednica 38: Uteži posameznih spremenljivk, vključenih v novo spremenljivko »Upravljanje z zaposlenimi

133 Preglednica 39: Povprečna vrednost in standardni odklon nove spremenljivke » Upravljanje z zaposlenimi «

134 Preglednica 40: Procesna organizacijska kultura

135 Preglednica 4I: KMO in Bartlettov test - procesna organizacijska kultura

135 Preglednica 42: Celotna pojasnjena varianca - procesna organizacijska kultura

135 Preglednica 43: Uteži posameznih spremenljivk, vključenih v novo spremenljivko »Procesna organizacijska kultura «

136 Preglednica 44: Povprečna vrednost in standardni odklon nove spremenljivke »Procesna organizacijska kultura«

136 Preglednica 45: Tržna usmerjenost

137 Preglednica 46: KMO in Bartlettov test - tržna usmerjenost

137 Preglednica 47: Celotna pojasnjena varianca - tržna usmerjenost

137 Preglednica 48: Uteži posameznih spremenljivk, vključenih v novo spremenljivko $\gg$ Tržna usmerjenost «

138 Preglednica 49: Povprečna vrednost in standardni odklon nove spremenljivke $\gg$ Tržna usmerjenost $\ll$

138 Preglednica 50: Vidik dobaviteljev

138 Preglednica 51: KMO in Bartlettov test - vidik dobaviteljev

139 Preglednica 52: Celotna pojasnjena varianca - vidik dobaviteljev 
139 Preglednica 53: Uteži posameznih spremenljivk, vključenih v novo spremenljivko $»$ Vidik dobaviteljev«

139 Preglednica 54: Povprečna vrednost in standardni odklon nove spremenljivke $\gg$ Vidik dobaviteljev«

140 Preglednica 55: Procesna informacijska tehnologija

I40 Preglednica 56: KMO in Bartlettov test - procesna informacijska tehnologija

14I Preglednica 57: Celotna pojasnjena varianca - procesna informacijska tehnologija

I4I Preglednica 58: Uteži posameznih spremenljivk, vključenih v novo spremenljivko $\gg$ Procesna informacijska tehnologija $\ll$

I4I Preglednica 59: Povprečna vrednost in standardni odklon nove spremenljivke $\gg$ Procesna informacijska tehnologija

142 Preglednica 60: Korelacijska analiza

143 Preglednica 6r: Ocena regresijskih koeficientov $\mathrm{HI}_{\mathrm{I}}$

144 Preglednica 62: T-test 



\section{Krajšave}

AJPES Agencija Republike Slovenije za javnopravne evidence in storitve

APQC Ameriški center za produktivnost in kakovost (American Productivity and Quality Center)

ASQ Ameriško združenje za kakovost (American Society for Quality)

BPI izboljševanje poslovnih procesov (Business Process Improvement)

BPM management poslovnih procesov (Business Process Management)

BPMM zrelostni model poslovnih procesov (Business Process Maturity Model)

BPMS računalniško podprti sistemi za management poslovnih procesov (Business Process Management Systems)

BPO procesna usmerjenost (Business Process Orientation)

BPR reinženiring oziroma prenova poslovnih procesov (Business Process Reengineering)

BSC sistem uravnoteženih kazalnikov (Balanced Scorecard)

CBU z odjemalci povezane enote (Customer Business Unit)

CEO glavni izvršni direktor (Chief Executive Officer) 
CMM zrelostni model zmogljivosti procesa razvoja programske opreme (Capability Maturity Model)

CMMI integriran zrelostni model zmogljivosti (Capability Maturity Model Integration)

CRM management odnosov z odjemalci (Customer Relationship Management)

EFQM Evropska fundacija za kakovost managementa (European Foundation for Quality Management)

EN evropski standard (European Norm)

ERP poslovno-informacijski sistem (Enterprise Resource Planning)

ameriška multinacionalna tehnološka in svetovalna korporacija (International Business Machines Corporation)

ISO Mednarodna organizacija za standardizacijo (International Organization for Standardization)

IoT Internet stvari (Internet of Things)

IT informacijske tehnologije (Information Technology)

ITK informatika in telekomunikacije

JIT ravno ob pravem času (Just in time)

JUSE Japonsko združenje znanstvenikov in inženirjev (Japanese Union of Scientists and Engineers)

Kanban Signalizacija s sistemom vleke (pull system)

OECD Organizacija za gospodarsko sodelovanje in razvoj (Organisation for Economic Co-operation and Development)

OMG mednarodni konzorcij za razvoj tehnoloških standardov (Object Managemenet Group) PDCA Demingov krog nenehnega izboljševanja (Plan-Do-Check-A-
ct)

PMBOK Vodnik po znanju projektnega vodenja (Project Management Body of Knowledge)

RFID radiofrekvenčna identifikacija (Radio Frequency IDentification)

ROA donos na sredstva (Return On Assets)

ROE donos na kapital (Angleško Return On Equity) 
ROIC donos na investiran kapital (Return On Invested Capital)

SAIDI povprečno trajanje prekinitev napajanja v sistemu (System Average Interruption Duration Index)

SAIFI povprečna frekvenca prekinitev napajanja v sistemu (Average Interruption Frequency Index)

SEI Software Engineering Institute Univerze Carnegie Mellon

SIST Slovenski inštitut za standardizacijo

SMED enominutna izmenjava (Single-minute exchange of dies),

SW programska oprema (Software)

TQM celovito upravljanje kakovosti (Total Quality Management)

TPS Toyotin proizvodni sistem (Toyota Production System)

ZDA Združene države Amerike

Preprosta metodologijo za organiziranje delovnih področij,

s S ki se osredotoča na vizualni red, organizacijo, čistočo in standardizacijo.

$6 \sigma \quad$ šest sigma (Six Sigma) 



\section{Uvod}

Pričujoča monografija predstavlja raziskavo merjenja zrelosti procesne usmerjenosti v elektroenergetski dejavnosti Slovenije. Osredotoča se na ugotavljanje ravni zrelosti procesne usmerjenosti in prepoznavanje priložnosti za nadaljnje uveljavljanje procesnega delovanja organizacij v podporo uspešnemu uresničevanju njihovih strategij. $S$ tem se monografija uvršča med raziskave $\mathrm{v}$ managementu in znotraj tega na področje procesne usmerjenosti in managementa poslovnih procesov. $\mathrm{V}$ zadnjih desetih, petnajstih letih se na tem področju intenzivno razvijajo in uveljavljajo zrelostni modeli procesne usmerjenosti. Monografija bralcem omogoča celovit vpogled $\mathrm{v}$ razvoj konceptov procesov, procesne usmerjenosti in managementa poslovnih procesov. $S$ predstavitvijo rezultatov in ugotovitev meritve zrelosti procesne usmerjenosti v izbrani dejavnosti prinaša uvid $\mathrm{v}$ koristnost merjenja in uporabe zrelostnih model za razvijanje posameznih sposobnosti ter zrelosti procesne usmerjenosti organizacije $\mathrm{v}$ podporo uspešnemu uresničevanju strategij in trajnostno uspešnemu razvoju.

Organizacije svoja poslanstva, vizije in strategije vsakodnevno uresničujejo $\mathrm{z}$ množico najrazličnejših aktivnosti. $S$ ciljem uspešnega in učinkovitega delovanja ter doseganja pričakovanih rezultatov želi management potrebne aktivnosti izvajati kar se da optimalno. Zato poskuša vse aktivnosti, potrebne za načrtovane izhode, smiselno povezovati v zaključene celote, imenovane poslovni procesi (Harrington 2006). Takšno razumevanje delovanja organizacije omogoča managementu osredotočanje zaposlenih na zahteve in pričakovanja odjemalcev, kar povečuje agilnost organizacije ter uspešnost in učinkovitost pri uresničevanju sprejetih strategij (Harmon 20ıo). Seveda je zato potrebno spreminjati miselnost 
zaposlenih in organizacijsko kulturo, ki namesto prevladujoče funkcijske postavlja v ospredje procesno usmerjenost in delovanje. Prav zaradi zgornjih spoznanj in koristi procesne usmerjenosti (Porter 1985) so se začele odlične organizacije v svetu konec osemdesetih let prejšnjega stoletja zelo sistematično ukvarjati s svojimi poslovnimi procesi in njihovim izboljševanjem. Začele so se uveljavljati generične procesne sheme (Davenport 2005). Pomembno spodbudo uvajanju procesnega pristopa v organizacije je tako v svetu kot v Sloveniji leta 2000 prinesla tretja izdaja široko uveljavljenega standarda za sistem vodenja kakovosti ISO 900 I:2000' (SIST 2000), ki je zahtevala uporabo procesnega pristopa pri vzpostavitvi sistema vodenja kakovosti. Ne le certificirane, tudi številne druge organizacije so v zadnjem desetletju in pol veliko energije, časa in denarja vložile v dokumentiranje svojih poslovnih procesov, bistveno manj pa v potrebne spremembe miselnosti, organizacijskih vrednot in kulture, potrebne za hitrejše uveljavljanje procesne usmerjenosti (Prosen in Novak 20ı0).

\section{Opredelitev raziskovalnega problema}

Procesna usmerjenost ali procesna naravnanost odraža razumevanje in delovanje organizacije skozi njene poslovne procese. Razvijanje procesne usmerjenosti organizacije prinaša številne koristi in odpira prostor managementu poslovnih procesov $\mathrm{v}$ podporo uspešnemu uresničevanju strategije organizacije. Za razliko od funkcijske usmerjenosti, ki ima že več kot dvestoletno tradicijo in je v organizacijah še vedno prevladujoča, se procesna usmerjenost uveljavlja šele od druge polovice osemdesetih let preteklega stoletja. Michael Porter je leta 1985 predstavil svoj koncept verige vrednosti, medsebojno povezanih procesov, ki jih podjetja izvajajo s ciljem povečevanja konkurenčnih prednosti (Porter 1985). Leto kasneje je takšno celovito razumevanje verige procesov od dobaviteljev materialov in opreme na vhodni strani do kupcev na izhodni strani predstavil Edvard Deming z diagramom poteka v knjigi Out of the Crisis (Deming 1986). Funkcijska usmerjenost teži k zagotavljanju potrebnega števila specialistov za učinkovito delovanje posameznih funkcij, medtem ko se procesna usmerjenost osredotoča na kupce in izpolnjevanje njihovih zahtev in pričakovanj. O tem, kako podjetja organizirati na temelju procesov, kako procese meriti, managirati in izboljševati, sta v svoji knjigi Impro-

Poln naziv slovenskega prevoda mednarodnega standarda je SIST EN ISO 900 I:20 I 5 , kjer je SIST kratica za Slovenski inštitut za standardizacijo, EN kratica za evropski standard, ISO kratica za Mednarodno organizacijo za standardizacijo, 900 r številka standarda in 2000 letnica izdaje standarda. 
ving Processes celovito pisala Rummler in Brache (1990). Hammer je kot način premagovanja konflikta med funkcijsko usmerjenostjo (»Komu poročam?《) in procesno usmerjenostjo (»Komu dodajam vrednost? «) videl razvijanje procesne usmerjenosti in prenove procesov $\mathrm{z}$ uporabo informacijske tehnologije kot ključnega dejavnika (Hammer in Champy 1993). Management poslovnih procesov lahko razumemo tudi kot strateški način upravljanja organizacij za izboljševanje uspešnosti delovanja (Van Looy, De Backer in Poels 20I I). V zadnjih letih je vse več raziskav o vplivih procesne usmerjenosti in managementa poslovnih procesov na uspešnost poslovanja organizacij (Škrinjar 2010; Roeser in Kern 2015).

Organizacije pri uvajanju in izboljševanju managementa poslovnih procesov ubirajo različne poti in uporabljajo različne pristope. Pri tem je pomembno, da napredek in uspeh pri uvajanju merijo z uporabo modelov zrelosti (De Boer, Müller in Schwengber ten Caten 2015). V teoriji in še posebej v praksi je poznanih na desetine modelov zrelosti managementa poslovnih procesov. Modeli so večinoma javno dostopni, uporabljajo pa se tudi modeli, ki so zaščiteni kot intelektualna lastnina svetovalnih podjetij in raziskovalnih institutov (Röglinger, Pöppelbuß in Becker 2012). Kljub temu koncept zrelosti managementa poslovnih procesov velja za sorazmerno nov koncept. Avtorji modele večinoma delijo v dve skupini: za merjenje zrelosti posameznega procesa in za merjenje zrelosti poslovnih procesov na ravni organizacije (Smith in Fingar 2003; Hammer 2007). Večina modelov vključuje od 4 do 9 faktorjev uspeha oziroma elementov ter 3 do 5 zrelostnih ravni (Röglinger, Pöppelbuß in Becker 201 2; Poeppelbuss, Plattfaut in Niehaves 2015). Avtorji opozarjajo, da je potrebno razlikovati med zrelostjo organizacije, ki odslikava izpolnjevanje vseh elementov uporabljanega modela zrelosti na doseženi ravni, in sposobnostjo, ki se vedno nanaša le na posamezen element modela (Van Looy, De Backer in Poels 2011).

Merjenje zrelosti procesne usmerjenosti in uporaba zrelostnih modelov seveda zahtevata poglobljeno znanje in več napora, a prinašata globlje razumevanje in številne priložnosti za izboljšave na področju managementa poslovnih procesov. Kljub temu se merjenje in zrelostni modeli procesne usmerjenosti $\mathrm{v}$ slovenskem prostoru, pa tudi širše, redko uporabljajo. Posledično v organizacijah ni pričakovanega prispevka managementa poslovnih procesov $\mathrm{k}$ uspešnemu poslovanju in uresničevanju strategij. Prav fenomen težavnega in počasnega uveljavljanja procesne usmerjenosti ter procesnega delovanja organizacij predstavlja naš raziskovalni problem. 


\section{Namen in cilji raziskave}

Iz pregleda stanja dosegljive literature in virov na področju merjenja procesne usmerjenosti in zrelostnih modelov smo opredelili raziskovalni problem, ki nam je omogočil določitev namena in ciljev raziskave.

Namen raziskave je bil izmeriti doseženo raven procesne zrelosti v organizacijah elektroenergetske verige Slovenije. Elektroenergetska veriga predstavlja enega najpomembnejših temeljev delovanja in razvoja ne le gospodarstva, ampak celotne družbe. Organizacije v verigi neprekinjeno, 24 ur na dan, odjemalcem zagotavljajo zanesljivo in varno proizvodnjo, prenos in distribucijo električne energije. $\mathrm{V}$ podporo varnosti in zanesljivosti dobave električne energije organizacije s področja elektroenergetike že vrsto let izboljšujejo svoje procese in sisteme vodenja. Meritve zrelosti procesne usmerjenosti $\mathrm{v}$ dveh organizacijah s tega področja so opozorile, da navkljub vsem tem naporom in sistemom razvitost procesne usmerjenosti ostaja na nezavidljivi ravni, kar je bila spodbuda za raziskavo v celotni elektroenergetski verigi.

$\mathrm{V}$ empirični raziskavi smo izvedli merjenje procesne usmerjenosti v organizacijah na področju proizvodnje, prenosa in distribucije električne energije. Vključili smo tudi družbo Informatika, d. d., ki za nekatere družbe v omenjeni verigi izvaja IT $^{2}$-storitve, zato vodje v tej družbi procese v panogi dobro poznajo. V zaključnem delu raziskave smo za 5 elektrodistribucijskih podjetij na osnovi meritev procesne usmerjenosti določili stopnje zrelosti in jih primerjali z izbranimi kazalniki njihove poslovne uspešnosti.

Rezultati in ugotovitve raziskave bodo vodstvom organizacij predstavili možnosti za uvedbo ustreznih izboljšav za povečanje uspešnosti managementa poslovnih procesov v podporo uresničevanju vizij in strategij.

Namen raziskave smo postopoma uresničevali skozi naslednje cilje, ki jih prikazuje slika I:

Ci s pregledom relevantne literature in virov preučiti obstoječe stanje na področju procesne usmerjenosti in managementa poslovnih procesov ter njunega pomena za uspešno poslovanje organizacij;

$\mathrm{C}_{2}$ s pregledom relevantne literature in virov preučiti uveljavljene modele procesne zrelosti in koristi njihove uporabe;

$\mathrm{C}_{3} \mathrm{z}$ izbranim instrumentom izmeriti zrelost procesne usmerjenosti organizacij v elektroenergetski verigi Slovenije; 
$\mathrm{C}_{4}$ izmerjene ravni zrelosti procesne usmerjenosti elektrodistribucijskih podjetij z uporabo javno dostopnih podatkov Agencije Republike Slovenije za javnopravne evidence in storitve (AJPES 2016) primerjati z njihovo poslovno uspešnostjo.

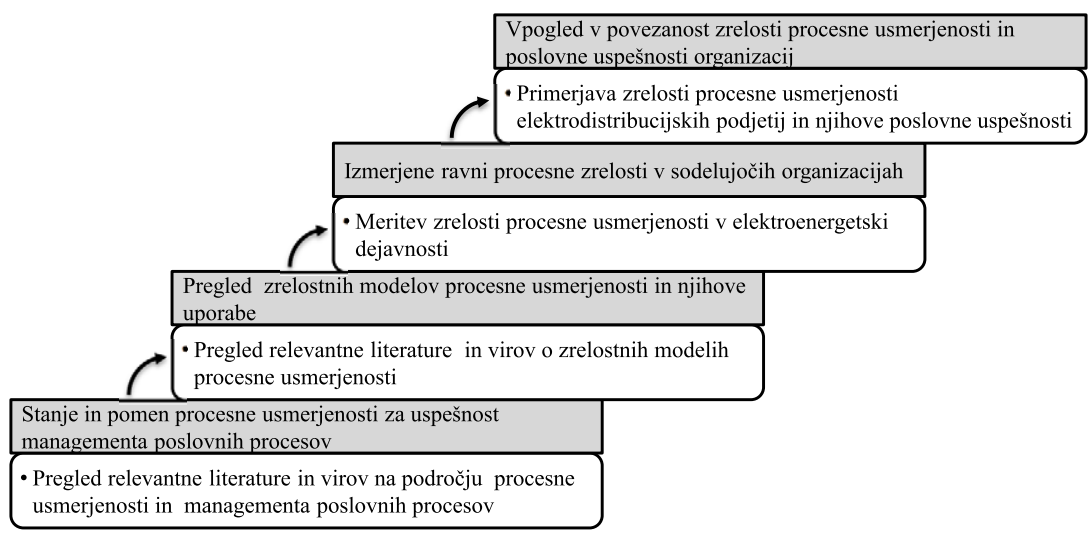

Slika ı: Cilji in rezultati raziskave

\section{Razvoj teze in hipotez}

Temeljna teza raziskave je, da pri uvajanju procesne usmerjenosti in managementa poslovnih procesov vodstva organizacij premalo pozornosti namenjajo t. i. »mehkim vsebinam «, to je vrednotam, organizacijski kulturi in vedenju, ki spodbuja procesno delovanje. Na uspešnost uvajanja managementa poslovnih procesov pomembno vplivata strateška zavezanost vodstva in uveljavljena vloga lastnikov procesov (Hernaus, Vukšić in Štemberger 2016). V praksi se management poslovnih procesov pogosto izvaja le $\mathrm{v}$ posameznih delih organizacije brez povezave $s$ strategijo organizacije (Jeston in Nelis 2007). V številnih organizacijah ostajajo funkcionalne meje med organizacijskimi enotami izrazite ter ostajajo občutne ovire za učinkovito izvajanje medfunkcijskih oziroma medorganizacijskih procesov ter za uspešnost managementa poslovnih procesov (McCormack 2007). Od tod prva hipoteza, ki smo jo na podlagi empirične raziskave podvrgli statistični presoji:

Hipoteza I: Slabša razvitost »mehkih« elementov, povezanih z vodi-

teljstvom, kot so procesna organizacijska kultura, struktura in upravljanje z zaposlenimi, zmanjšuje raven procesne zrelosti organizacij. 
Druga hipoteza se nanaša na dojemanje procesne usmerjenosti vrhnjega oziroma srednjega in nižjega managementa. Praksa pogosto opozarja, da vrhnji management pozitivneje ocenjuje zrelost procesne usmerjenosti in uspešnost managementa poslovnih procesov. Od tod druga hipoteza, ki smo jo preverili z empirično raziskavo:

Hipoteza 2: Srednji in nižji management kritičneje ocenjuje uspešnost udejanja procesne usmerjenosti in managementa poslovnih procesov od vrhnjega vodstva.

\section{Predstavitev raziskovalnih metod}

Raziskava je po svoji paradigmi kvantitativna, saj sloni na merjenju zrelosti procesne usmerjenosti z izbranim merskim instrumentom (Hair idr. 2006). V meritev smo vključili organizacije s področja proizvodnje, prenosa in distribucije električne energije v Sloveniji.

Za dosego prvega cilja smo pregledali in analizirali literaturo s področja procesne usmerjenosti in managementa poslovnih procesov ter njunega pomena za uspešno poslovanje organizacij.

Za dosego drugega cilja smo s pregledom relevantne literature in virov preučili uveljavljene modele zrelosti procesne usmerjenosti in njihov pomen za uspešno uveljavljanje managementa poslovnih procesov.

Za dosego tretjega cilja smo izvedli meritev zrelosti procesne usmerjenosti v organizacijah s področja proizvodnje, prenosa in distribucije električne energije v Sloveniji. V raziskavo smo vključili 19 organizacij s področja proizvodnje, prenosa in distribucije električne energije v Sloveniji. Vključili smo tudi družbo Informatika, d. d., ki za nekatere družbe v omenjeni verigi izvaja IT-storitve, zato njeni vodje dobro poznajo procese v elektroenergetiki. V anketiranje smo vključili tako vrhnji, srednji kot nižji management ter managerje projektov. Velikost populacije je bila 450 managerjev in vzorec anketiranih je zajel celotno populacijo, tj. 450 managerjev. Vprašalniki so bili anketirancem posredovani v soglasju in $s$ podporo predsednikov uprav oziroma direktorjev organizacij po ustaljenih poteh notranjega obveščanja, zaradi česar smo lahko pričakovali višjo odzivnost anketirancev. Kot merilni instrument smo uporabili anketni vprašalnik s 7-stopenjsko Likertovo lestvico, ki omogoča dovolj možnosti za izražanje stopnje strinjanja (Škrinjar 2010). Anketiranje smo izvedli preko spletnega portala EnKlikAnketa z uporabo odprtokodne aplikacije $\mathrm{IKA} .{ }^{3}$ Vprašalnik smo predhodno preskusili na testnem vzorcu 34 re-

IKA je ime aplikacije za brezplačno storitev spletnega anketiranja, ki jo razvija Center za družboslovno informatiko (CDI) Fakultete za družbene vede Univerze v Ljubljani. 
spondentov $\mathrm{v}$ eni od organizacij dejavnosti. $\mathrm{Na}$ osnovi izpolnjenih vprašalnikov iz raziskave smo za vsak element procesne usmerjenosti najprej izvedli opisno statistiko (izračun frekvenc, srednjih vrednosti in standardnega odklona). Za namene preverjanja zastavljenih hipotez smo v nadaljevanju z metodo glavnih komponent za vsak element določili faktorje/ glavne komponente, ki pojasnijo čim večji delež celotne variance. Hipotezo I smo preverili s korelacijsko in regresijsko analizo. Hipotezo 2 smo preverili s t-testom za neodvisne vzorce.

Za dosego četrtega cilja smo za pet organizacij s področja elektrodistribucije na osnovi povprečne vrednosti kategorij procesne usmerjenosti $\mathrm{z}$ upoštevanjem meja zrelostnih stopenj določili njihove ravni zrelosti na McCormackovem zrelostnem modelu (McCormack in Johnson 200I). Za elektrodistribucijska podjetja velja, da so v celotni elektroenergetski verigi med seboj najprimerljivejša. Izvajajo enako poslanstvo distribucije električne energije do odjemalcev, zanje velja isti zakonski in regulatorni okvir, tudi $\mathrm{z}$ vidika poslovnih procesov in organizacijske strukture so si zelo podobna. Razlike med njimi so pogojene predvsem s strukturo in številom odjemalcev ter z velikostjo in geografskimi značilnostmi področja, na katerem delujejo. Zaradi te stopnje primerljivosti organizacij smo na osnovi javno dostopnih podatkov v bazi AJPES analizirali njihove poslovne rezultate in pridobili vpogled $\mathrm{v}$ povezanost med uspešnostjo poslovanja in zrelostjo procesne naravnanosti. Zaradi majhnosti vzorca in $s$ tem povezane neizpolnjenosti pogojev za uporabo običajnih parametričnih ali neparametričnih metod (Hair idr. 2006) smo analizo izvedli kot eksplorativno kvalitativno raziskavo in izziv za prihodnja raziskovanja. Naše izhodiščne ugotovitve bodo vodstvom organizacij omogočile koristen vpogled in širše razumevanje pomena procesne usmerjenosti za uspešno poslovanje pa tudi osnovo ter spodbudo za nadaljevanje meritev in statistično preverjanje $\mathrm{v}$ prihodnosti.

\section{Omejitve in predpostavke}

Prvo omejitev predstavlja dejstvo, da je bila meritev zrelosti procesne usmerjenosti izvedena na omejenem vzorcu organizacij elektroenergetske verige Slovenije, torej organizacij, ki proizvajajo, prenašajo in distribuirajo električno energijo do odjemalcev. Druga omejitev se nanaša na čas, v katerem je bila meritev izvedena. Zaradi finančnih težav v družbi Termoelektrarna Šoštanj, d. o. o., in posledično celotnem Holdingu Slovenske elektrarne ter napovedanih prestrukturiranjih se je med zaposlenimi stopnjevalo nezadovoljstvo, sindikat pa je napovedoval stavko. Ob tem 
so $\mathrm{v}$ času anketiranja kar v treh vključenih družbah potekali postopki za imenovanje predsednika uprave oziroma direktorja družbe.

Naslednjo omejitev predstavlja dejstvo, da imajo tovrstni rezultati raziskav značaj poslovne skrivnosti, kar za raziskavo predstavlja določeno omejitev. Za elektrodistribucijska podjetja smo na osnovi rezultatov meritev določili ustrezne stopnje zrelosti procesne usmerjenosti, kar ima prav tako značaj poslovne skrivnosti. Za dosego četrtega cilja smo analizo zaradi majhnosti vzorca in s tem povezane neizpolnjenosti pogojev za uporabo običajnih parametričnih metod izvedli z uporabo neparametričnih metod (Hair idr. 2006). Naslednja omejitev se nanaša na to, da raziskava vključuje primerjavo izmerjene stopnje zrelosti le $\mathrm{z}$ javno dostopnimi rezultati iz letnih poročil elektrodistribucijskih podjetij. Poročila vključujejo predvsem ekonomske in finančne kazalnike, medtem ko vrsta tehničnih in ekonomsko tehničnih kazalnikov, pa tudi kazalnikov dela z zaposlenimi, ni dostopna. Uporabljeni kazalniki so torej le delen prikaz dejanske poslovne uspešnosti organizacij.

Izbran zrelostni model je osredotočen na organizacijo kot celoto, zato podaja povprečno splošno sliko in ne omogoča podrobnejših vpogledov $\mathrm{v}$ zrelost posameznih procesov. Vendar imajo organizacijski dejavniki pomemben vpliv na vsak posamezen proces $v$ organizaciji, kar še posebej velja za nižje ravni zrelosti, ko procesi niso vzpostavljeni.

Koristnost raziskave vidimo predvsem $\mathrm{v}$ tem, da bo seznanjenost $\mathrm{z}$ njenimi rezultati vodstvom organizacij te izjemno pomembne gospodarske dejavnosti pomagala celoviteje in globlje razumeti dejavnike uspešnosti uveljavljanja procesne usmerjenosti in managementa poslovnih procesov. To pa bo pomemben prispevek $\mathrm{k}$ nadaljnjim izboljšavam na tem področju.

\section{Uporaba pojmov in izrazoslovje}

$\mathrm{Na}$ obravnavanih področjih se tako v literaturi, v akademskem svetu, kot $\mathrm{v}$ praksi za podobne ali celo enake vsebine uporabljajo različni izrazi. Ta različnost se $s$ slovenjenjem še poveča. V monografiji uporabljamo v slovenskem jeziku najpogosteje uporabljane izraze, npr. skrbnik procesa. Uporabo slovenskih izrazov, pa tudi izvorna poimenovanja $\mathrm{v}$ angleškem jeziku, razlagamo s sprotnimi opombami. Ko zaradi pogostega navajanja obravnavanih vsebin uporabljamo kratice, jih zaradi lažjega razumevanja uporabljamo izvorno v angleškem jeziku, npr. za management poslovnih procesov uporabljamo kratico BPM. 


\section{Poslovni procesi in procesni pristop}

Osredotočenost na procese kot načine doseganja kakovosti in zadovoljstva odjemalcev je promoviral že Shewhart v letih I93I in 1939 (Cronemyr in Danielsson 2013, 933). Toda do intenzivnega uveljavljanja koncepta poslovnih procesov in managementa poslovnih procesov je prišlo šele sredi 80 -ih let prejšnjega stoletja. $V$ ozadju tega razmaha leži potreba po hitrejšem in uspešnejšem razvijanju sposobnosti organizacij za zadovoljevanje vedno višjih zahtev in pričakovanj odjemalcev iter drugih deležnikov. Intenzivna globalizacija in tektonske politične spremembe $\mathrm{v} 80-\mathrm{ih}$, ki so podirale meje in spreminjale družbeno-ekonomske sisteme v svetu, so še izostrile potrebo po konkurenčnosti in odzivnosti organizacij na globalnih trgih. V tem obdobju je tudi industrija v Združenih državah Amerike (ZDA) izgubljala številna delovna mesta, predvsem zaradi intenzivnosti in kakovosti konkurence iz Azije ter rasti storitvenih dejavnosti (Smith 2007). Pristopi managementa organizacij in zagotavljanja kakovosti, razviti v 70-ih letih, niso več zadoščali. $V$ teh pogojih se je začel močno uveljavljati pristop celovitega upravljanja kakovosti $\left(T_{Q}{ }^{\prime}\right)$. Danes TQM dojemamo kot filozofijo in skupek načel ter pristopov, ki predstavljajo temelj nenehnega izboljševanja organizacij. Načela celovitega upravljanja kakovosti vključujejo osredotočenost na odjemalce, usmerjenost na procese, strateški in sistemski pristop, vključevanje zaposlenih in komuniciranje, odločanje na podlagi dejstev in nenehno izboljševanje (ASQ, 2016). 8o-ta leta so bila tudi čas, ko se je v praksi vse bolj uveljavljalo sistemsko razumevanje organizacije (Harmon 2003, 20). V kontekstu teh velikih iz- 
zivov je Michael Porter prepoznal priložnosti, ki jih je za razvijanje konkurenčnosti organizacij ponudilo celovito razumevanje aktivnosti v verigi vrednosti (slika 2). Čeprav je Porterjeva ideja v literaturi s področja managementa poslovnih procesov velikokrat navedena, jo zaradi njenega temeljnega pomena za uveljavljanje procesnega razumevanja in delovanja organizacij prikazujemo tudi za potrebe naše raziskave.

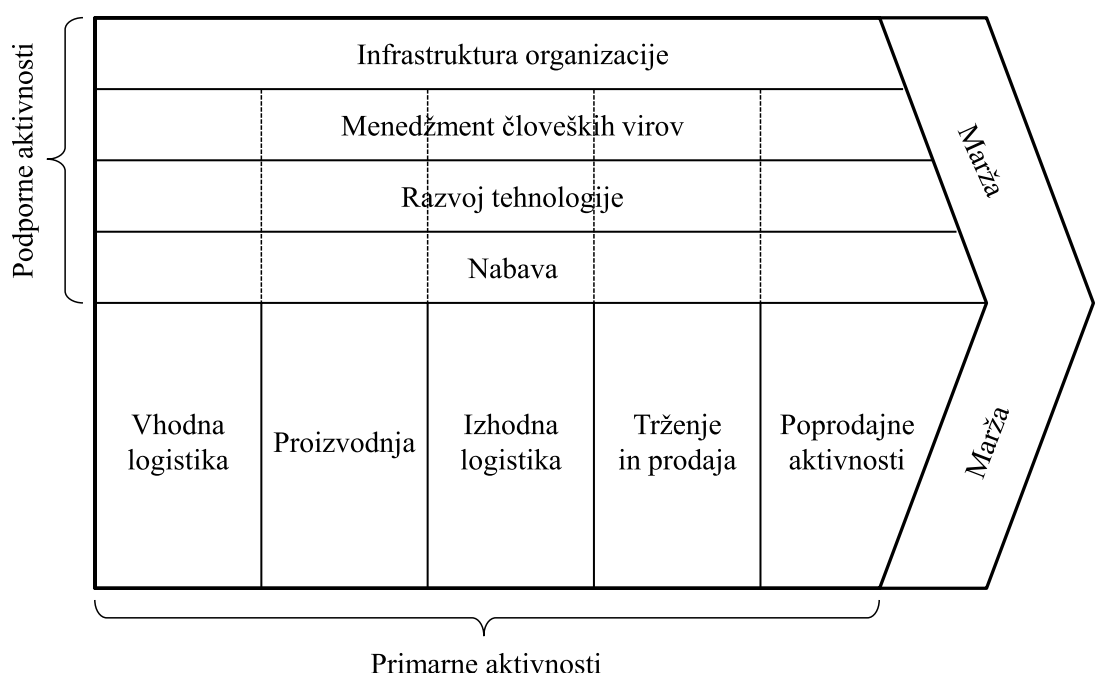

Slika 2: Porterjeva veriga vrednosti

Vir: Porter $1985,37$.

Zagotavljanje konkurenčnosti v stalno spreminjajočem se svetu zahteva nenehno povečevanje učinkovitosti dela in uporabe tehnologij. Osredotočenost na procese in njihovo uspešno izvajanje odpira prostor ter zagotavlja potrebno infrastrukturo za uvajanje in uporabo novih pristopov ter tehnologij za uspešno uresničevanje ciljev organizacije (CMMI Institut 20IO, 4). $\mathrm{CMMI}^{2}$ je kratica za integriran zrelostni model zmogljivosti.

\section{Poslovni procesi skozi čas}

$\mathrm{V}$ nadaljevanju si oglejmo kontekst in nekatere ključne prispevke k uveljavljanju procesov in managementa poslovnih procesov za uspešnost organizacij od sredine 8o-ih let dalje. Leto za tem, ko je Porter objavil svoje razumevanje organizacije skozi verigo vrednosti, je Imai na Japonskem 
predstavil filozofijo nenehnega izboljševanja kaizen ${ }^{3}$ kot temelj japonske konkurenčnosti in uspeha (Imai 1986). V 80-ih letih je japonski proizvajalec Toyota zaradi izjemne kakovosti in zanesljivosti avtomobilov, visoke produktivnosti in prilagodljivosti prevzel vodilno vlogo $\mathrm{v}$ svetu ter potisnil ameriško avtomobilsko industrijo v nezavidljiv položaj. Toyotina filozofija in uspeh temeljita na dolgoročnem razmišljanju, učinkovitem odpravljanju vseh izgub v procesih, spoštovanju ter sodelovanju ljudi in partnerjev ter reševanju problemov na osnovi nenehnega učenja in izboljševanja (Liker 2004). Taiichi Ohno, utemeljitelj Toyotinega proizvodnega sistema $\left(\mathrm{TPS}^{4}\right)$, značilnosti sistema pojasni $\mathrm{z}$ obvladovanjem časa od potrditve naročila kupca do prejema denarja (Ohno 1988, po Liker 2004, 7). Ta čas skrajšujejo $z$ odstranjevanjem vseh izgub, ki ne dodajajo vrednosti. Zaradi Toyotinega uspeha postane TPS osnova filozofije vitke proizvodnje, ki skupaj s šest sigma v 9o-ih letih prevzame vodilno vlogo pri optimizaciji proizvodnih procesov.

V ZDA, ki so se v tistem obdobju otepale s hudo gospodarsko krizo, je Deming s knjigo Out of Crisis postavil temelje prestrukturiranja ameriškega gospodarstva. Njegovo temeljno izhodišče je bilo, da se kakovost in produktivnost ne izključujeta, temveč obratno. Z izboljševanjem kakovosti se povečuje tudi produktivnost, saj je manj nepotrebnih popravil in izgub. Svoj pogled na potrebne spremembe v vodenju ameriških organizacij je predstavil v 14 načelih transformacije (Deming 1986). Načela poudarjajo predvsem potrebo po spremembi stila vodenja in organizacijske kulture. Deming poziva $\mathrm{k}$ nadomeščanju managementa $\mathrm{z}$ voditeljstvom, vključevanju ljudi, sistemskemu pristopu in nenehnemu izboljševanju kakovosti izdelkov in storitev. $Z$ našega vidika preučevanja procesnega razumevanja in delovanja organizacij pa sta pomembni predvsem dve načeli. Deveto načelo poziva k odpravljanju preprek med organizacijskimi enotami, saj te ovirajo pretočnost aktivnosti. Zadnje, štirinajsto načelo, pa poziva $\mathrm{k}$ vključevanju slehernega zaposlenega $\mathrm{v}$ organizaciji $\mathrm{v}$ prizadevanja za uresničitev transformacije. $Z$ drugimi besedami to pomeni osredotočenost zaposlenih na končne rezultate in uspešnost celote, kar je temelj procesnega razumevanja delovanja organizacij. V tej knjigi Deming $\mathrm{z}$ diagramom poteka predstavi tudi svoje razumevanje organizacije kot sistema.

Zaradi velikih težav s kakovostjo izdelkov je Motorola v 80-ih letih razvila novo metodologijo izboljševanja kakovosti, šest sigma (6s), ki slo-

\footnotetext{
V japonskem jeziku kai pomeni spremembo, zen pa dobro. Kaizen je torej nenehno izboljševanje, za katerega si prizadeva vsakdo, vsak dan, kjer koli (Kaizen Institute 2016).

$4 \quad$ TPS je kratica za Toyota Production System.
} 
ni na statistični kontroli procesov. Namesto da bi število napak spremljali na tisoč izdelkov, so v Motoroli kakovost oziroma cilje kakovosti ambiciozno določili s številom napak na milijon izdelkov (Jeston in Nelis 2007). 6s namreč pomeni verjetnost le 3,4 napak oziroma problemov na milijon izdelkov. Zaradi uspehov Motorole je metodologijo v 90-ih letih najprej uporabil in populariziral General Electric. Takratni glavni izvršni direktor (CEO') Jack Welch je metodologijo uvedel v celotno korporacijo in kar $40 \%$ dodatka za delovno uspešnost managerjev vezal na doseganje ciljev 6s. Sledila je implementacija metodologije v številnih drugih ameriških podjetjih. $6 \mathrm{~s}$ je sčasoma prerasla v filozofijo in vključila številne pristope in orodja TQM. Če so $6 s$ najprej uporabljali v proizvodnih procesih, se danes vse bolj uveljavlja tudi v storitvenih dejavnostih, še posebej v kombinaciji z metodologijo vitke organizacije.

V začetku 9o-ih let je Hammer spodbudil obdobje reinženiringa oziroma prenove poslovnih procesov $\left(\mathrm{BPR}^{6}\right)$. Po njegovem mnenju je bilo nujno opustiti zastarele poslovne modele in jih nadomestiti z novimi, ki bodo sloneli na nekaj temeljnih procesih, medfunkcijskem sodelovanju ter informacijski in organizacijski tehnologiji. Radikalno novi procesi naj bi prinesli velike spremembe delovnih mest in organizacijske strukture. Prenovljene organizacije so strateško naravnane, osredotočene na kupce in usmerjene na končne rezultate. Po Hammerjevem mnenju naj bi takšen poslovni model bistveno povečal uspešnost in dobičkonosnost organizacij (Hammer 1990). A radikalne spremembe najprej zahtevajo spremembe managementa, vrednot in kulture organizacije ter vzpostavitev sistema merjenja uspešnosti procesov.

Leta 1993 je Davenport utemeljil pomen inoviranja poslovnih procesov z uporabo informacijskih tehnologij. Procesni pogled na poslovanje po Davenportu prinaša čisto nove perspektive in predstavlja ključni vidik inoviranja. Zaradi svoje drugačnosti od funkcionalnega pogleda pomeni pravi preobrat $\mathrm{v}$ glavah. Razvoj računalnikov ter informacijskih in komunikacijskih tehnologij (IKT) ponuja učinkovitejša orodja za inoviranje procesov. Organizacije, ki prepoznajo priložnosti, a tudi omejitve uporabe IKT-tehnologij, slednje lahko z uporabo orodij za modeliranje ter sistemski in informacijski inženiring na inovativen način uporabijo za izboljševanje procesov (Davenport 1993). Konec istega leta je Byrne $\mathrm{v}$ uvodniku revije Businessweek promoviral pojem horizontalne organizacije. Zastarele organizacijske strukture, kjer številni hierarhični nivoji dušijo odločanje in povzročajo stroške (vertikalne organizacije), je treba

CEO je kratica za Chief Executive Officer.

6 BPR je kratica za Business Process Reengineering. 
nadomestiti s horizontalnimi organizacijami z majhnim številom hierarhičnih nivojev in zabrisanimi funkcijskimi mejami. Organizacije imajo $3-5$ bistvenih procesov $\mathrm{z}$ določenimi cilji in skrbniki. Hierarhija je sploščena, kontrola in aktivnosti so zmanjšane na minimum, operacije, ki ne dodajajo vrednosti, odpravljene, delo izvajajo timi. S tem člankom je Byrne populariziral izraz horizontalna organizacija in vzpostavil definicijo na procese usmerjenega organizacijskega modela (Byrne 1993).

Sredi 9o-ih let se uveljavi management poslovnih procesov. Pomemben je prispevek Melana iz ameriške multinacionalne tehnološke in svetovalne korporacije $\mathrm{IBM}^{7}$, ki objavi več člankov o uspešni uporabi managementa procesov v proizvodnji. Predstavi uporabo različnih orodij, od statistične kontrole procesa, analize cikla procesa, analize variabilnosti do procesa nenehnega izboljševanja. Management poslovnih procesov se vse bolj uveljavlja kot najpomembnejši organizacijski pristop za izboljševanje (DeToro in Mc Cabe 1997).

Zaradi uspešnosti organizacij, ki so uvedle procesni pristop in management poslovnih procesov, njihova načela in dobre prakse uporabi tudi standard ISO 900 I. Z radikalno spremenjeno izdajo leta 2000 postavi zahtevo, da organizacije svoje sisteme vodenja kakovosti zasnujejo na osnovi procesov. Ker standard pomembno prispeva k uveljavljanju procesne usmerjenosti in delovanja, zahteve za procesni pristop obravnavamo ločeno v razdelku 2.3.

Po letu 2000 se v svetu kaže povečano zanimanje za uvajanje procesnega pristopa in managementa poslovnih procesov. Smith in Fingar procesno upravljano organizacijo opredelita kot digitalizirano organizacijo prihodnosti (Smith in Fingar 2003). Vse več je raziskav in znanstvenih člankov na temo procesne usmerjenosti, uveljavlja se uporaba modelov zrelosti procesne usmerjenosti kot vodilo za izboljševanje uspešnosti managementa poslovnih procesov. Teoretična izhodišča teh konceptov obravnavamo v poglavjih 4 in 5 .

Različni avtorji poudarjajo tudi druge pomembnejše mejnike uveljavljanja koncepta procesov in managementa poslovnih procesov. Tako Smith ključne premike predstavi s štirimi valovi (Smith 2007). Prvi val predstavlja afirmacija TQM sredi 8o-ih let. Drugi val sproži reinženiring poslovnih procesov, ki ga je s člankom »Reengineering Work: Don't Automate, Obliterate « v reviji Harvard Business Review leta 1990 napovedal Michael Hammer. Reinženiring je namesto postopnih izboljšav ponujal korenite spremembe in velike koristi, a prinašal tudi velika tveganja (Hammer 1990). Zato je po nekaj letih velikega optimizma navdušenje 
za reinženiring splahnelo. Tretji val Smith prepoznava v prizadevanjih za vzpostavitev organizacijske strukture, ki povečuje osredotočenost na procese. Pomembnost tega vala avtor $(2007,23)$ vidi v tem, da je vse več organizacij začelo spoznavati, kako pomemben dejavnik je bila uspešnost delovanja procesov pri odločanju na najvišjem nivoju. Četrti val Smith prepoznava v povezovanju procesov $s$ strategijo, ko izjemno uspešni procesi ustvarjajo prihodnost organizacije. Vse jasneje postane, da ni mogoče izkoristiti številnih priložnosti in reševati zahtevnejših problemov zgolj znotraj posameznih funkcij.

Razvoj in uveljavljanje koncepta procesov, managementa procesov in zrelosti shematsko prikazuje slika 3 .

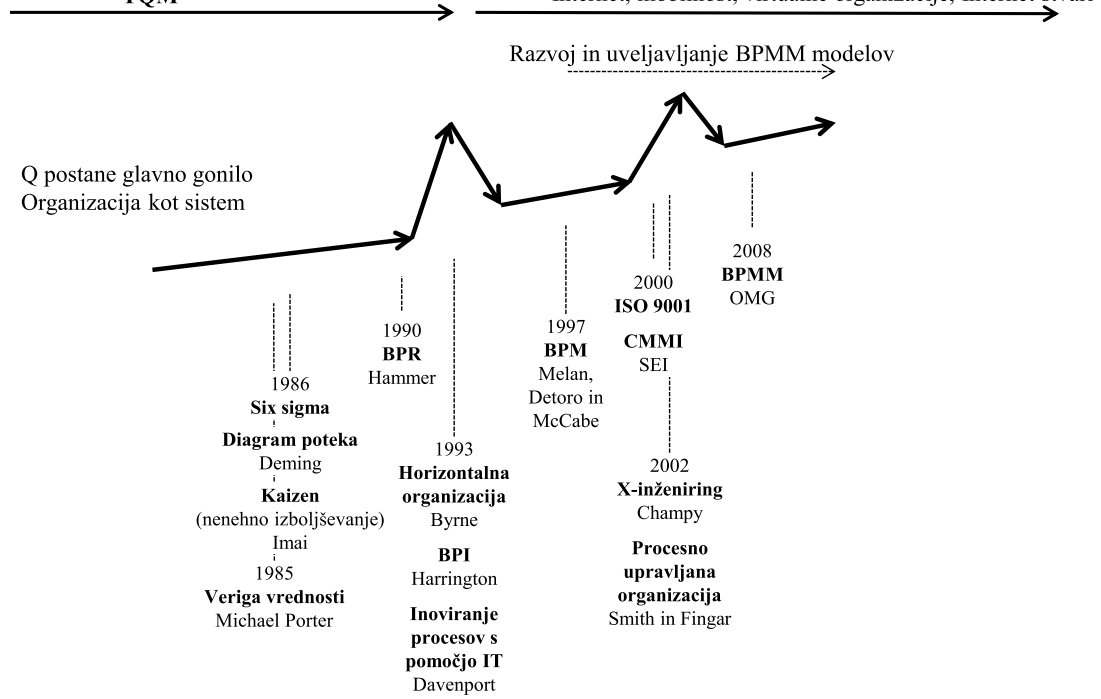

Slika 3: Razvoj in uveljavljanje koncepta procesov, BPM in BPMM ${ }^{8}$

Vir: Povzeto in prilagojeno po Sharp in McDermott 2009, 23; McCormack 2007, 19-42; Van Looy 2014, 7-13.

V zadnjih 25 letih avtorji vse bolj poudarjajo procese end-to-end'. Van Looy (20I4, Io) v tem obdobju prepoznava štiri sodobne evolucije v kako-

8 BPMM je kratica za zrelostni model poslovnih procesov (angl. Business Process Maturity Model).

9 »End-to-end « je v svetu uveljavljena fraza v angleškem jeziku, ki poudarja celoten proces, od začetka do konca - torej proces, ki presega funkcijske ali celo organizacijske meje. Ker se široko uporablja tudi pri nas, ga zaradi lažje razumljivosti ne prevajamo. 
vosti razmišljanja o poslovnih procesih. Prvo evolucijo predstavlja BPR, ki sta ga v zgodnjih 9o-ih letih uveljavila Hammer in Champy. Sledi Harrington in izboljševanje poslovnih procesov (BPI) sredi 90-ih let. Tretjo evolucijo po mnenju avtorice povzroči Champy leta 2002 z X-inženiringom poslovnih procesov, četrto pa istega leta Smith in Fingar $s$ tretjim valom BPM. Dva od omenjenih pristopov, BPR in X-inženiring, poudarjata potrebo po radikalnih spremembah procesov, medtem ko se drugi in četrti pristop, BPI in tretji val, osredotočata na postopne izboljšave. Z $\mathrm{X}$-inženiringom, ki predstavlja drugi val BPR, je Champy spremenil svoj prvotni pogled na BPR z začetka 9o-ih let. Ta je bil osredotočen predvsem na zniževanje stroškov in je $s$ tem prinašal koristi zgolj lastnikom. X-inženiring pa je osredotočen na tehnološko podprte procese in povezovanje med organizacijami ter $z$ odjemalci, kar naj bi omogočilo velike izboljšave in koristi za vse deležnike (Champy 2002, II).

Vse večja globalizacija poslovanja in vse bolj zaostreni pogoji gospodarjenja še poudarjajo pomen izboljševanja in inoviranja procesov. $\mathrm{V}$ praksi se uveljavijo trije koncepti izboljševanja procesov: teorija omejitev $\mathrm{ToC}^{10}$, vitkost in 6s (Nave 2002, po Van Looy 2014, I0-1 I). Uspešnost izboljševanja in inoviranja pa ni odvisna le od sistematičnih pristopov, metodologij in tehnologij. Vse bolj prisotno je zavedanje o pomenu človeškega dejavnika, zato avtorji poudarjajo pomen organizacijske strukture, organizacijske kulture in procesne usmerjenosti (McCormack in Johnson 2001; Roseman in de Bruin 2005).

Zadnja leta se vodilne organizacije na področju procesov osredotočajo na razvijanje procesne arhitekture, uveljavljanje managementa in merjenja procesov, standardizacijo procesov skozi celotno organizacijo, izvajanje projektov vitke organizacije ter uvajanje novih tehnologij in računalniško podprtih sistemov za management poslovnih procesov oziroma BPMS" (Harmon 2014, XXVii).

Zgornji pregled uveljavljanja koncepta procesov, managementa procesov in procesne usmerjenosti skozi čas kaže na vedno večjo dinamiko sprememb. Ni več trajnih konkurenčnih prednosti, so zgolj začasne (McGrath 2013, cit. po Van den Bergh idr. 2016). Zato je potrebno nenehno razmišljati o naslednjih strateških možnostih za srednjeročni uspeh, pa čeprav smo pravkar sprejeli novo strategijo. Tudi management poslovnih procesov je pred zahtevnimi izzivi. Do danes se je BPM uveljavil predvsem kot pristop za management in izboljševanje uspešnosti in

Io ToC (Theory of Constraints) je metodologija izboljševanja proizvodnih procesov, ki temelji na prepoznavanju in odpravljanju ozkih grl v procesih.

I $\mathrm{BPMS}$ je kratica za Business Process Management Systems. 
učinkovitosti notranjih procesov. V praksi ga številni dojemajo kot analitičen, inženirski pristop za reševanje problemov. V dobi odjemalcev se mora BPM izkazati tudi $\mathrm{v}$ zunanjih povezavah in procesih, $\mathrm{v}$ dodajanju vrednosti za odjemalce in izboljševanju njihovih uporabniških izkušenj. Preplavlja nas val digitalizacije, ki v ospredje postavlja skrb za razvoj storitev. Novi pristopi razvijanja storitev, kot sta $\mathrm{UX}^{12}$ in $\mathrm{SDT}^{13}$ ponujajo nove možnosti razvoja in uveljavljanja BPM kot strateškega orodja za preoblikovanje organizacij (Van den Bergh idr. 2016).

\section{Procesi v managerskih orodjih}

Ker organizacije naravno delujejo skozi procese ter njihovo izboljševanje pomembno prispeva $\mathrm{k}$ njihovi uspešnosti in učinkovitosti, so procesi danes sestavni del vseh najbolj uveljavljenih managerskih sistemov in modelov, če omenimo samo sistem vodenja kakovosti in standard ISO 900I, model odličnosti Evropske fundacije za kakovost managementa $\left(\mathrm{EFQM}^{14}\right)$, sistem uravnoteženih kazalnikov $\left(\mathrm{BSC}^{15}\right)$ in vitko organizacijo (slika 4).

Sistem vodenja kakovosti po zahtevah standarda ISO 900 I je procesno zasnovan. Procesni pristop je eno od načel vodenja kakovosti, ki ga podrobneje obravnavamo $v$ razdelku 2.3.I. Koncept modela odličnosti EFQM sloni na naravnem načelu soodvisnosti med vzroki in posledicami. Če vodstvo in organizacija delata prave stvari, pravočasno in na pravi način, je večja verjetnost, da bosta uresničevala zastavljene rezultate. Model odličnosti EFQM na osnovi najboljših praks vodenja odličnih organizacij prepoznava 5 dejavnikov uspeha. Procesi, izdelki in storitve so eden izmed teh petih dejavnikov. BSC strateško uspešnost organizacij uravnoteženo obravnava 4 vidikov: vidika učenja in rasti, vidika notranjih procesov (vidika dejavnikov), vidika trga in kupcev ter finančnega vidika (vidika rezultatov). Sistem je uravnotežen zato, ker upošteva tako finančne kot nefinančne vidike, tako notranje kot zunanje vidike ter tako kratkoročne kot dolgoročne interese deležnikov organizacije (Neely idr. 2002, 3; Stovall, Neill in Perkins 2004, 223-24, cit. po Janeš 2015, 100). Tudi v modelu ledene gore za ohranjanje vitkosti je management procesov eden od petih ključnih elementov.

\footnotetext{
I UX je kratica za pristop k razvijanju storitev User Experience design.

I 3 SDT je kratica za pristop k razvijanju storitev Service Design Thinking.

I4 EFQM je kratica za European Foundation for Quality Management.

is BSC je kratica za Balanced Scorecard.
} 


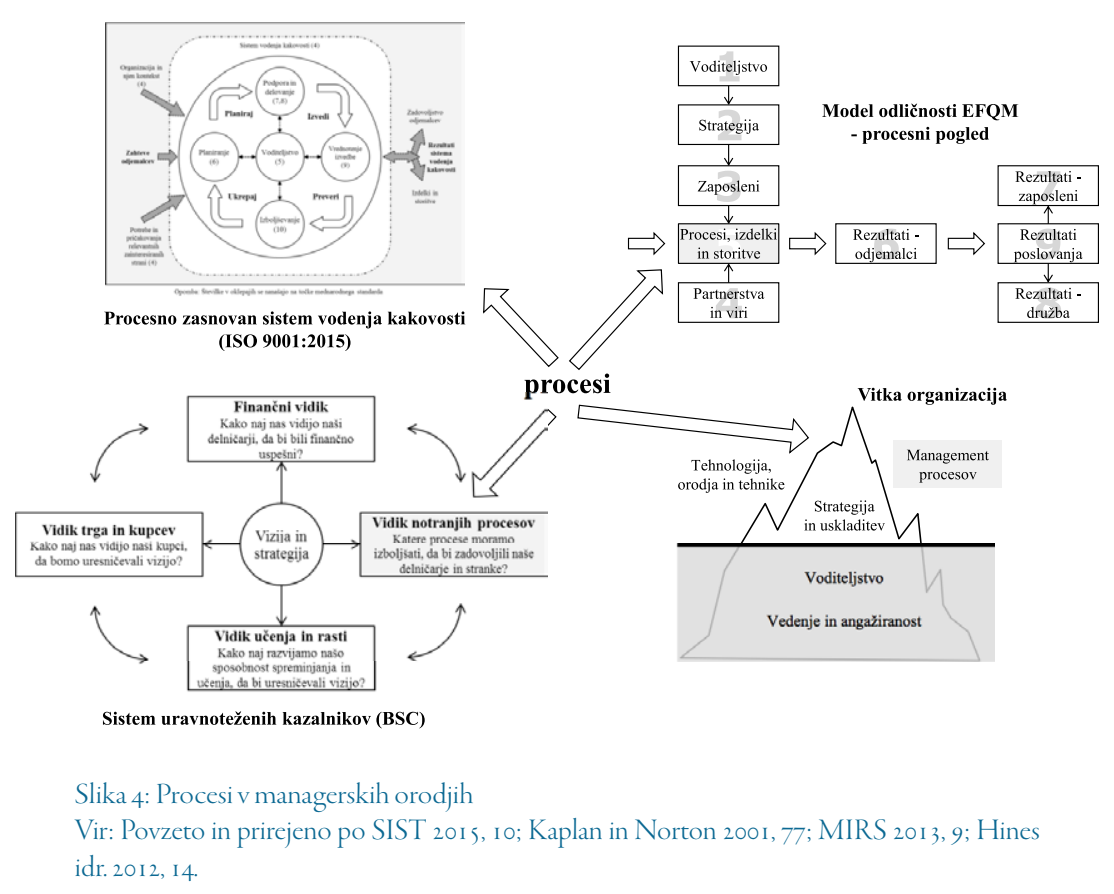

\section{Razumevanje poslovnih procesov in definicije ${ }^{16}$}

Poslovne procese ali preprosto procese različni avtorji obravnavajo v različnih kontekstih in na različne načine. Harrington (1991, 9) poudarja, da procesi za zagotavljanje končnih rezultatov uporabljajo sredstva organizacije. Na podlagi izkušenj v IBM razlikuje med proizvodnimi in poslovnimi procesi. Proizvodni proces je proces, ki je v fizičnem kontaktu $\mathrm{z}$ izdelki, ki bodo dobavljeni zunanjemu odjemalcu. Kot poslovne procese razume vse ostale storitve in procese, ki podpirajo proizvodne procese, npr. proces naročanja, proces načrtovanja proizvodnega procesa ali proces odpreme in logistike. Poslovni procesi torej uporabljajo sredstva organizacije za doseganje načrtovanih rezultatov, ki podpirajo cilje organizacije.

Burlton procese razume kot vse tiste aktivnosti, ki jih moramo narediti za to, da odjemalcu damo, kar pričakuje. Avtor procese razume širše, kot sredstva organizacije, podobno kot zaposlene, informacije, stroje in opremo. Procesi predstavljajo okvir, ki povezuje vsa ostala sredstva in vse

I6 V dispoziciji smo načrtovali ločili razdelek 2.3. I Procesi v storitvenih dejavnostih. V sami nalogi pa obravnavamo vse procese, tako v proizvodnih kot storitvenih dejavnostih, tako da ločena obravnava procesov v storitvenih dejavnostih v kontekstu naloge ni smiselna. 
vidike sprememb: človeške vire, objekte, računalniške in komunikacijske tehnologije, organizacijske strukture, vloge in opravila ter politike, pravila in predpise (Burlton 200r).

Da bi procese lahko izboljševali, jih moramo razumeti. Harrington (I99I, II4) izpostavlja naslednje karakteristike poslovnih procesov in ustrezna vprašanja za njihovo razumevanje:

- Pretok Načini transformacije vhodov v izhode?

- Uspešnost Kako uspešno izpolnjujemo pričakovanja odjemalcev?

- Učinkovitost Kako racionalno uporabljamo vire za želeni rezultat?

- Čas cikla Čas, ki je potreben za transformacijo vhodov vizhode?

- Stroški Strošek obravnavanega procesa?

Tudi pri definicijah procesov velja, da je definicij vsaj toliko kot avtorjev. V preglednici I smo zbrali nekaj uveljavljenih definicij pojma proces.

Definicije se glede na teoretična spoznanja in praktične izkušnje $s$ časom tudi dopolnjujejo in razvijajo. Ključni elementi, uporabljeni pri večini definicij, so: nabor aktivnosti, vhodi, transformacija, izhodi, vrednost za odjemalce ter uresničevanje poslovnega namena in ciljev. DeToro in McCabe $(1997,56)$ pa proces preprosto določita kot »način, kako se delo opravi «.

Preglednica r: Primeri definicij pojma proces

\begin{tabular}{|c|c|}
\hline Proces & Vir \\
\hline $\begin{array}{l}\text { Vsaka aktivnost ali skupina aktivnosti, ki vzame vhod, mu doda vrednost in notran- } \\
\text { jemu ali zunanjemu kupcu zagotovi izhod. }\end{array}$ & Harrington I991, 9 \\
\hline $\begin{array}{l}\text { Skupina aktivnosti, ki vzame eno ali več vrst vhodov in ustvari izhod, ki ima vred- } \\
\text { nost za odjemalca. }\end{array}$ & Hammer in Champy 1993, 35 \\
\hline $\begin{array}{l}\text { Potek aktivnosti: } \\
\text { - ki so strukturirane tako, da ustvarijo predhodno definiran izhod, ki ima vrednost } \\
\text { za kupca, } \\
\text { - ki imajo dobro definiran začetek in konec ter se ponavljajo, } \\
\text { - ki jih izvajajo ljudje, ki po možnosti pripadajo različnim funkcijam oz. organizaci- } \\
\text { jskim enotam in pri tem izrabljajo vire, } \\
\text { - da uresničujejo kratkoročne in dolgoročne cilje organizacije. }\end{array}$ & $\begin{array}{l}\text { Seibt idr. 1997, cit. po } \\
\text { Križman in Novak 2002, } 18\end{array}$ \\
\hline $\begin{array}{l}\text { Pravi proces vsebuje vse tiste stvari, ki jih naredimo zato, da nekomu zagotovimo to, } \\
\text { kar pričakuje. }\end{array}$ & Burlton 200I, 72 \\
\hline $\begin{array}{l}\text { Proces organizacije, ki opisuje standarden nabor aktivnosti, ki jih organizacija potre- } \\
\text { buje za obravnavo ene ali več poslovnih zahtev. }\end{array}$ & $\mathrm{OMG}^{\mathrm{1}} 2008,454$ \\
\hline
\end{tabular}


Skupina medsebojno povezanih aktivnosti, ki se začnejo kot odziv na sprožitveni dogodek in realizirajo določen konkreten rezultat za kupca in druge zainteresirane strani procesa.

Sharp in McDermott 2009,67

Nabor medsebojno povezanih aktivnosti, ki vhode spremenijo v izhode, da bi uresničile določen namen.

CMMI Institut 2010, 486

Mreža aktivnosti, ki se ponavljajo in katerih cilj je ustvariti vrednost za notranje ali zunanje odjemalce.

Bergman in Klefsjö 20ı, povz. po Cronemyr in Danielsson 2013,934

Poslovni proces sestavlja nabor aktivnosti, ki se koordinirano izvajajo v organizacijskem in tehničnem okolju. Aktivnosti skupaj uresničujejo poslovne cilje. Posamezen proces se izvaja v eni organizaciji, vendar lahko deluje vzajemno s procesi v

Weske 2012,5 drugi organizaciji.

\section{Procesni pristop}

$\mathrm{V}$ razdelku 2.I smo med pomembnejše mejnike pri uveljavljanju procesnega razumevanja in delovanja organizacij uvrstili tudi tretjo izdajo standarda ISO 900 I v letu 2000 (SIST 2000). Standard vse od prve izdaje leta $1987 \mathrm{v}$ svetu uveljavlja pomen kakovosti in sistema kakovosti za uspešno poslovanje ter razvoj organizacij. Uporabnikom v praksi omogoča učenje na dobrih praksah vodenja kakovosti in izboljševanje. Koncept sistema vodenja kakovosti v standardu sloni na štirih korakih managementa, danes najširše poznanih kot Demingov krog nenehnega izboljševanja oziroma PDCA ${ }^{17}$. Izvor tega kroga moramo iskati v delu profesorja Walterja A. Shewharta, ki je že v 20-ih letih prejšnjega stoletja utemeljeval pomen statistične kontrole za obvladovanje proizvodnje $\mathrm{v}$ treh korakih procesa, načrt - proizvodnja - pregled. Leta 1939 je Shewhart ta proces prvič predstavil kot krog. Deming je krog kasneje nekoliko preimenoval in nadgradil v štiri korake: načrtovanje - proizvodnja - prodaja - raziskovanje (na osnovi povratnih informacij kupcev o kakovosti in ceni izdelkov). Začel je poudarjati, kako pomembno je za kakovost izdelkov in storitev krog nenehno ponavljati. Pristop je uspešno populariziral na svojih predavanjih na Japonskem v letih 1950 in I95 I, kamor ga je povabilo Japonsko združenje znanstvenikov in inženirjev (JUSE) ${ }^{18}$. Demingovo kolo, kakor so ga poimenovali Japonci, so direktorji in inženirji, udeleženci enega od seminarjev, preimenovali v krog Plan-Do-Check-A-

I7 PDCA je kratica za Plan-Do-Check-Act.

I8 JUSE je kratica za Union of Japanese Scientists and Engineers. Združenje japonskih znanstvenikov in inženirjev je bilo ustanovljeno leta I 946 z namenom promocije sistematičnih raziskav za napredek znanosti in tehnologij ter s tem prispevanja $\mathrm{k}$ razvoju kulture in industrije (JUSE 2016). 
ct. V 6o-ih letih se je PDCA-krog na Japonskem razvil v krog nenehnega izboljševanja in managersko orodje (Moen in Norman 2006). Zaradi izjemno hitrega in uspešnega razvoja Japonske se je uporaba PDCA-kroga nato hitro širila in uveljavila tudi drugod po svetu.

Standard ISO 900 pa vse od prve izdaje ni omogočal le učenja in izboljševanja, ampak tudi certificiranje s strani neodvisnih certifikacijskih organov. Certifikati potrjujejo, da organizacije uspešno izvajajo sistem vodenja kakovosti ter $\mathrm{s}$ tem nenehno izboljšujejo kakovost izdelkov in storitev v zadovoljstvo svojih odjemalcev. To priložnost so odjemalci, najprej v avtomobilski industriji, nato pa tudi v drugih panogah hitro prepoznali in od svojih dobaviteljev zahtevali, da svojo kakovost in sposobnost nenehnega izboljševanja potrdijo $\mathrm{z}$ neodvisnim certifikatom. To je bil eden ključnih razlogov za intenzivno rast uporabe standarda $\mathrm{v}$ svetu. Po podatkih ISO je imelo konec leta $2014 \mathrm{~V}$ svetu kar I.138.I55 organizacij certifikat ISO 900 (ISO 2015). Prav zaradi tega izjemnega prispevka k popularizaciji procesnega pristopa zaslužijo zahteve standarda tudi našo pozornost.

Snovalci standarda spremljajo in analizirajo najuspešnejše pristope na področju managementa kakovosti $\mathrm{v}$ svetu in jih $\mathrm{v}$ razumljivem časovnem zamiku, 5 do Io let, po doseženem konsenzu glede njihove uspešnosti $\mathrm{v}$ praksi povzemajo $\mathrm{v}$ zahtevah standarda. Leta 2000 so zahteve standarda tako povzele splošno spoznanje, da mora biti sistem vodenja kakovosti procesno zasnovan (SIST 2000). To spoznanje so snovalci standarda v slovarju ISO 9000 (SIST 2005, 5) najprej povzeli v dve izmed takrat osmih »načel vodenja kakovosti «, in sicer:

I Procesni pristop: želeni rezultat se doseže uspešneje, kadar se aktivnosti in z njimi povezani viri vodijo kot proces.

2 Sistemski pristop k vodenju: identificiranje, razumevanje in vodenje med seboj povezanih procesov kot sistem pripomorejo $\mathrm{k}$ uspešnosti in učinkovitosti organizacije pri doseganju njenih ciljev.

Ti dve načeli so nato snovalci konkretizirali v zahtevah standarda. Za naše razumevanje so najpomembnejše splošne zahteve v točki 4.I, ki jih sporočilno vizualizira slika 5 . 


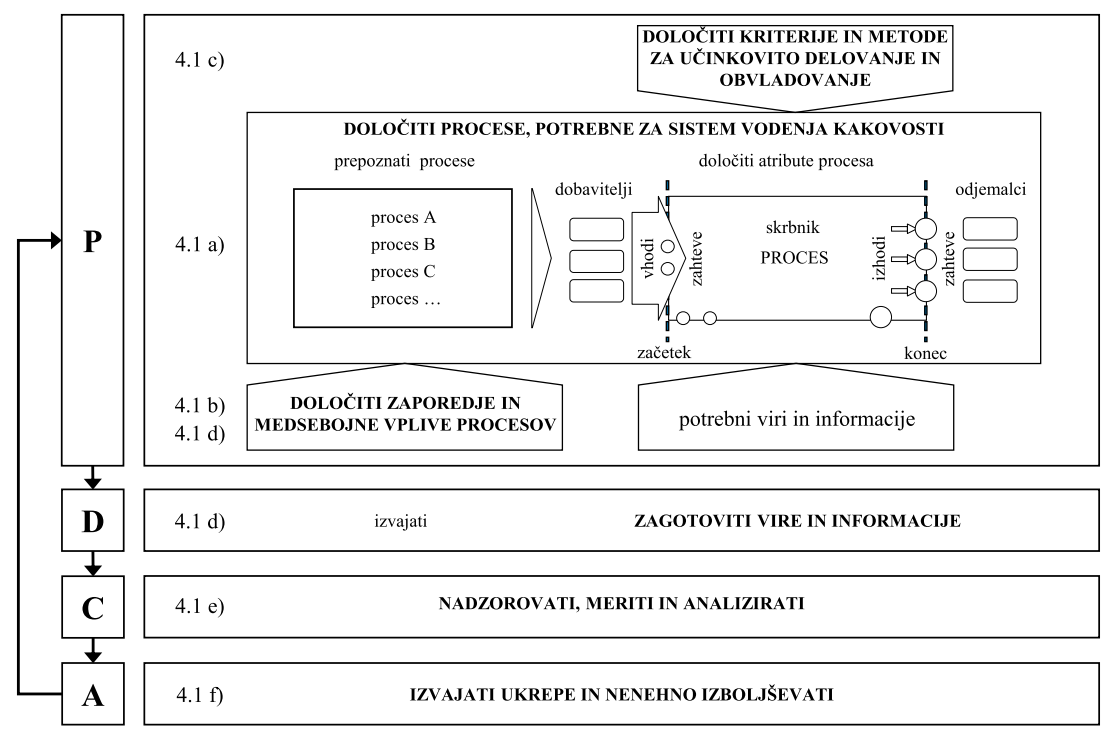

Vizualizacija nam pomaga razumeti, kako sistematično so snovalci standarda zahteve za management poslovnih procesov s pomočjo PDCA-kroga spustili z ravni organizacije na raven posameznega poslovnega procesa. V fazi načrtovanja je organizacija najprej dolžna določiti procese, potrebne za sistem vodenja kakovosti (točka standarda 4.I a), ter določiti zaporedje in medsebojne vplive procesov (4.I b). Čeprav standard ni podrobneje razčlenil zahtev za določitev procesov, pa je bilo na osnovi poznavanja managementa poslovnih procesov $\mathrm{v}$ praksi možno razumeti, da določitev procesov vključuje najprej razumevanje verige vrednosti in prepoznavanje arhitekture procesov, nato pa določitev atributov posameznega procesa, kot prikazuje zgornja slika 5. Naslednja zahteva standarda v točki 4.I.c določa, da mora organizacija določiti postopke za uspešno izvajanje in nadzor procesov. To zahteva potrebne vire, ki jih je treba ne le načrtovati, ampak predvsem zagotoviti (4.I.d). Izvajanje seveda ni zahteva standarda, saj se procesi v delujoči organizaciji vedno izvajajo, vprašanje je le, kako sistematično in kako uspešno. Zato pa standard v točki 4.I.e določa zahtevo za nadzorovanje, merjenje in analiziranje, ki vodstvu na osnovi objektivnih, merljivih rezultatov omogoča ustrezno ukrepanje in nenehno izboljševanje (4.I f). 
Kljub tako jasnemu sporočilu pa so številni uporabniki v praksi zahteve standarda razumeli predvsem kot potrebo po dokumentiranju procesov. Pri tem pogosto ni bila nedvoumno prepoznana veriga vrednosti in iz nje hierarhija procesov. Namesto tega so v organizacijah pogosto nekritično ali pa vsaj neprilagojeno uporabljali generične procesne sheme, npr. shemo Ameriškega centra za produktivnost in kakovost (APQC) ali kar procesni model iz samega standarda.

Nova izdaja standarda v letu 20I5 (SIST 2015) prinaša pomemben korak naprej pri uveljavljanju sistema vodenja kot managerskega orodja. Nov standard se tako z vidika vsebine, strukture kot tudi terminologije približuje svetu managerjev. Uvaja potrebo po razumevanju konteksta organizacije, prepoznavanju relevantnih deležnikov ter njihovih zahtev in pričakovanj ter na tej osnovi po oblikovanju jasnih strateških usmeritev. Morda najpomembnejšo spremembo predstavlja zahteva po strateškem in operativnem delovanju na osnovi obvladovanja tveganj ter priložnosti. Procesni pristop in PDCA-cikel ostajata temeljna koncepta sistema vodenja organizacije, saj njuna uporaba prispeva $k$ uspešnosti in učinkovitosti organizacije pri doseganju predvidenih rezultatov (SIST 2015, 9). Sedaj se jima je pridružilo še razmišljanje na osnovi tveganj.

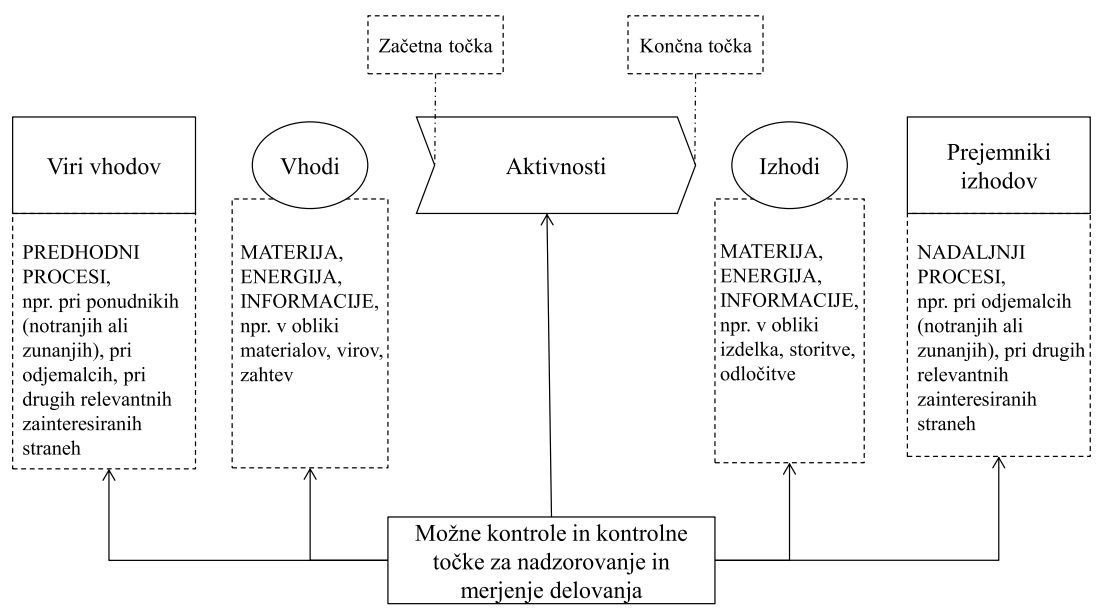

Slika 6: Shematični prikaz elementov procesa

Vir: SIST 2015, I0.

Glede zahtev za uporabo procesnega pristopa v novem standardu pravzaprav ni posebej novih zahtev. Morda je še najzanimivoejše dejstvo, 
da se je snovalcem standarda zdelo potrebno po is letih v sam standard vključiti shematični prikaz elementov procesa (slika 6).

\section{Arhitektura poslovnih procesov}

Organizacije so organizirane na najrazličnejše načine. To, kar zanima nas $\mathrm{z}$ vidika managementa poslovnih procesov, ni organizacijska struktura, $\mathrm{ki}$ je praviloma funkcijska, vertikalna, ampak struktura procesov organizacije. Verige vrednosti so praviloma sestavljene iz nekaj glavnih procesov, ki se zaradi kompleksnosti delijo navzdol na procese in podprocese, vse do posameznih aktivnosti oziroma opravil. Za prikaz te procesne strukture so se uveljavili izrazi, kot so struktura, hierarhija in arhitektura. V okviru naše raziskave uporabljamo izraz arhitektura procesov.

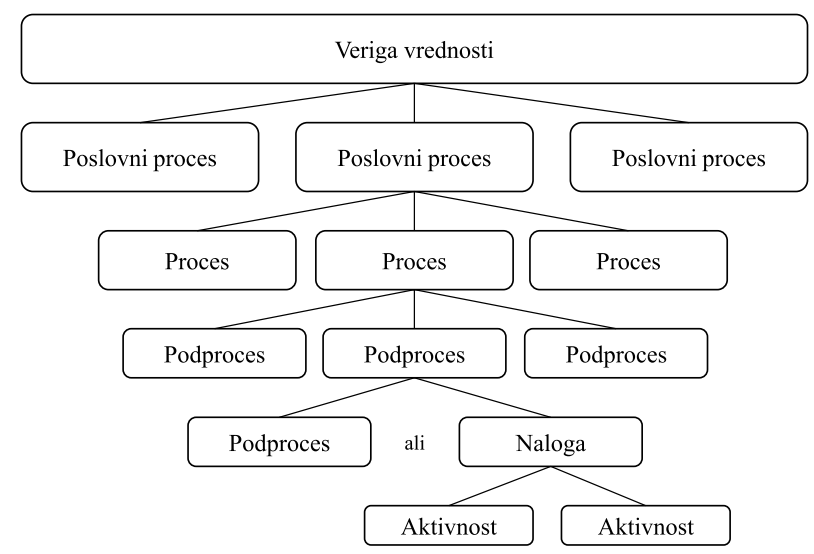

Slika 7: Generična hierarhija procesov

Vir: Harmon 2003, 80.

Arhitektura procesov je tekstualni ali shematski prikaz verige vrednosti in procesov organizacije. Dobra arhitektura procesov kaže, kako so verige vrednosti in procesi povezani med seboj ter s strategijo. Da bi se izognili nesporazumom, je pri uporabi termina arhitektura procesov vedno dobro dodati organizacije, saj to nedvoumno sporoča, da gre za pogled na najvišji ravni, za krovni pogled vseh procesov organizacije (Harmon 2003). Verigo vrednosti Harmon definira kot največji proces, ki vključuje vse od sprožitve razvojnega cikla izdelka in naročil do prodaje in zadnje poprodajne aktivnosti. Proces razume in uporablja kot kateri koli manjši del verige vrednosti, medtem ko je aktivnost najmanjši proces, ki ne pot- 
rebuje nadaljnje členitve. Harmonov generični prikaz hierarhije procesov prikazuje slika 7 .

CMMI Institut $(2010,488)$ hierarhijo procesov določa s procesi, podprocesi in procesnimi elementi. Proces je na najvišji ravni, je najsplošnejši pojem. Proces sestavljajo podprocesi, ki se lahko naprej delijo na procesne elemente ali ne. Procesni elementi na najnižji ravni so sestavljeni iz posameznih aktivnosti ali opravil in se ne delijo na manjše enote.

Prepoznavanje procesov in podprocesov je v praksi pogosto povezano s težavami. Pomagamo si s prepoznavanjem meja procesov (Sharp in McDermott 2009, 49). Poslovni proces je veriga end-to.end od začetnega dogodka do končnega rezultata, ki izhaja iz tega dogodka. Pri prepoznavanju podprocesov proces analiziramo $\mathrm{z}$ vidika pomembnih mejnikov na poti do želenega končnega rezultata. Mejnike želimo nadzorovati, tudi meriti. Podprocesi vključujejo aktivnosti procesa, potrebne za doseganje teh pomembnih mejnikov. Avtorja ugotavljata, da procesi v splošnem vključujejo $5 \pm 2$ podprocesa.

Harmon $(2014,88)$ poudarja, da je razvoj arhitekture naloga managerjev. Projekt poteka v 4 korakih. Prvi korak je določitev ciljev projekta, udeležencev in njihovih nalog. Drugi korak je namenjen pregledu ali določitvi strateških ciljev in strategije, določitvi deležnikov in vrednostne ponudbe ter verig vrednosti organizacije. $V$ tej fazi vključuje tudi intervjuje $\mathrm{z}$ deležniki. Tretji korak je namenjen prepoznavanju procesov življenjskega cikla v obravnavani verigi vrednosti. V zadnjem koraku vodstvo določi vsaj procese I. in 2. nivoja, torej glavne procese in podprocese verige vrednosti. Projekt v praksi običajno poteka v okviru delavnic $z$ vodstvom in traja od pol leta pa tudi do dveh let, odvisno od kompleksnosti organizacije in arhitekture procesov. Da bi skrajšali čas določitve arhitekture procesov, se organizacije danes vse bolj poslužujejo razširjenih okvirov procesov, kot sta npr. SCOR ${ }^{19}$ ali $\mathrm{PCF}^{20}$. Kadar ima organizacija vzpostavljen center odličnosti BPM, sta vzpostavitev in vzdrževanje arhitekture procesov nalogi tega centra.

\section{Vrste procesov}

V predhodni razlagi arhitekture procesov organizacije smo izhajali iz verige vrednosti in procesov, ki jo sestavljajo. Ti procesi so potrebni za zagotavljanje načrtovanih izdelkov in storitev ter so največkrat neposredno povezani z odjemalci. Številni avtorji tovrstne procese imenuje glavni

19 SCOR Supply Chain Operations Reference. Okvir, ki ga razvija APICS Supply Chain Council.

20 PCF Process Classification Framework, najšriše uporabljan okvir procesov, ki ga razvija APQC (American Productivity \& Quality Center). 
procesi ${ }^{21}$. Toda v organizaciji so tudi procesi, ki omogočajo izvajanje glavnih procesov. Že Porter je, kot izhaja s slike 2, razlikoval primarne in podporne aktivnosti (Porter 1985).

DeToro in McCabe $(1997,56)$ glavne procese opredelita kot procese, ki potekajo preko organizacijskih meja, zagotavljajo izhode, ki so za organizacijo strateško pomembni, in imajo velik vpliv na zadovoljstvo odjemalcev. Ti procesi torej omogočajo uresničevanje poslanstva organizacije, odzivanje na zahteve odjemalcev, zagotavljanje prihodkov in uresničevanje zastavljenih ciljev. Kot tipične primere glavnih procesov navajata razvoj izdelkov, izpolnjevanje naročil in izvajanje storitev. Za te procese se v praksi uporablja tudi izraz operativni procesi. Organizacije naj bi imele 10 do 20 glavnih procesov. Poleg glavnih so v organizaciji še notranji procesi, med katere avtorja uvrščata podporne in procese managementa. Med strateško pomembnimi podpornimi procesi navajata npr. dejavnosti na področju HRM, financ in informacijske podpore. Procesi managementa pa so procesi, $s$ katerimi vodje nadzorujejo delovanje in preverjajo doseganje rezultatov.

Procese pa lahko razvrščamo tudi na osnovi drugih kriterijev, npr. zaporedja aktivnosti v procesu. $V$ številnih procesih so aktivnosti standardizirane, potekajo po vnaprej znanem zaporedju in jih je možno zlahka modelirati v diagramu poteka. So pa procesi, v katerih aktivnosti potekajo sočasno, zelo prepleteno in včasih tudi neurejeno. Tipičen primer takih procesov so ustvarjalni oziroma kreativni procesi. $V$ takih primerih risanje diagramov potekov ni koristno početje. Glede na možnost modeliranja procesov Sharp in McDermott slednje delita v tri kategorije:

- izvršni oziroma strateški procesi,

- ustvarjalni oziroma sodelovalni procesi,

- transakcijski procesi.

Tudi Gardner (2004, 30-3I) loči tri vrste procesov, in sicer managerske, poslovne in podporne. Med poslovne procese uvršča tiste, ki odražajo edinstvene kompetence organizacij in so kritični za uresničevanje njenega poslanstva.

$\mathrm{V}$ okviru naše raziskave smo kot glavne procese razumeli procese, skozi katere se uresničuje poslanstvo organizacije, ki so v neposrednem kontaktu z odjemalci in/ali pomembno vplivajo na njihovo zadovoljstvo ter zagotavljajo prihodke. Kot ključne smo razumeli procese, ki so za us-

2 I Angl. Core Processes. Primerni prevodi pridevniške uporabe angleškega izraza »core « so osrednji, glavni, temeljni. V okviru naše raziskave smo uporabljali prevod glavni, kar je v Sloveniji v praksi tudi sicer zelo pogosto. 
peh organizacije strateško pomembni. Torej lahko organizacija kot ključen prepozna tudi strateško pomemben podporni ali managerski proces.

\section{Določitev procesov in opredelitev elementov procesa}

DeToro in McCabe $(1997,57)$ določitev procesov prepoznavata kot enega najuspešnejših načinov za začetek uvajanja managementa poslovnih procesov. Naloga in odgovornost vrhnjega vodstva je, da določi glavne procese in njihove medsebojne povezave pri prehajanju organizacijskih enot. Običajno so povezave opredeljene $\mathrm{z}$ določitvijo trenutka, ko izhod enega procesa postane vhod v drug proces. Naloga vrhnjega vodstva je, da določi tudi ime procesa in skrbnika procesa. Skupine, imenovane za posamezen proces, nato razgradijo glavni proces na procese in podprocese ter zanje izdelajo diagrame poteka. Še posebej je pomembno, da v tej začetni fazi vrhnje vodstvo določi prioritete za izboljševanje procesov. Osnova za to so strateški cilji organizacije in vprašanje, kako pomembno posamezen glavni proces vpliva na vsakega od strateških ciljev. Prednostni vrstni red procesov za izboljšave vrhnje vodstvo določi s soglasjem, z glasovanjem ali preprosto z določitvijo procesov, ki jih je potrebno izboljšati.

$\mathrm{Na}$ pomembnost pravilne določitve procesov opozarjata tudi Sharp in McDermott (2009, 63-64). Procesi naj bodo določeni na kar se le da visokem organizacijskem nivoju, saj preozko določeni procesi vedno težijo $\mathrm{k}$ notranji učinkovitosti in posledično le lokalnim optimizacijam namesto izboljševanju celote. Na določitev procesov ne smejo vplivati ne funkcije, ne organizacijske strukture, ne sistemi ali aplikacije.

Med bistvene sestavine procesa avtorja uvrščata sprožitveni dogodek, aktivnosti, potek dela in rezultat (slika 8). Posebno pozornost namenjata poimenovanju procesa, kar je pomembno sporočilo za uporabnike v praksi (Sharp in McDermott 2009). V organizacijah, v katerih vrhnje vodstvo ni osebno vključeno v uvajanje procesnega delovanja, pogosto ne prepoznajo procesov na najvišji ravni ali vsaj ne dosežejo konsenza glede tega, kateri so glavni procesi organizacije. Procese prepoznavajo na nižji ravni, pogosto kar v mejah organizacijskih enot in jih pogosto tudi poimenujejo kar z nazivi organizacijskih enot. Sharp in McDermott predlagata, da naj bo ime procesa oblikovano v edninski obliki glagol samostalnik, lahko tudi s kakovostnim pridevnikom ali dodatnim samostalnikom. Ime procesa naj nakazuje nameravani izhod oziroma rezultat procesa (npr. sprejeti naročilo storitve, razviti nov izdelek ali storitev, priskrbeti zunanje izvajalce ali izdelati strateški poslovni načrt). 


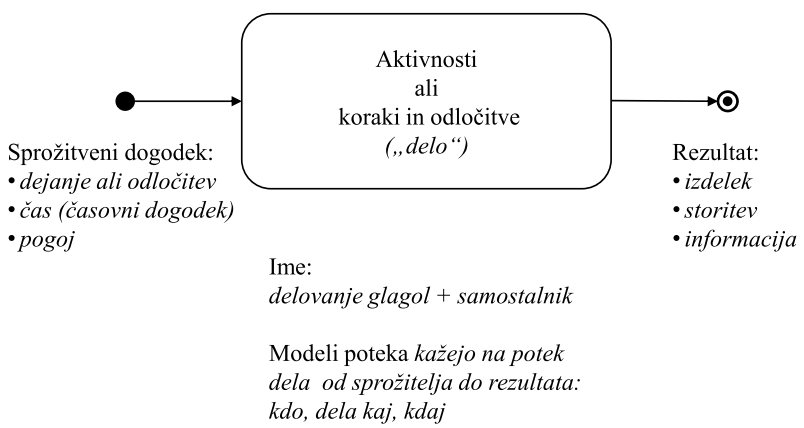

Slika 8: Bistvene sestavine procesa

Vir: Sharp in McDermott 2009, 45 .

Da so sprožitveni in zaključni dogodki pomembni elementi procesa, sporoča tudi standard ISO 9001:2015 (slika 6). Šele nedvoumno določene meje procesa omogočajo določitev primernega skrbnika procesa in njegovih odgovornosti. Določitev končnih dogodkov omogoča opredelitev izhodov procesa na tej meji, odjemalcev ter njihovih zahtev in pričakovanj - in podobno na vhodni strani. Ko opredelimo začetni dogodek, omogočimo opredelitev vhodov v proces, določitev njihovih dobaviteljev ter določitev zahtev procesa za posamezne vhode. $Z$ določitvijo meja procesov se zmanjšujejo področja sivih lis, v katerih odgovornosti za aktivnosti niso nedvoumno določene.

O elementih procesa smo govorili že $\mathrm{v}$ razdelku 2.3, ko smo povzeli skupne elemente izbranih definicij pojma proces: začetni in končni dogodki, izhodi in odjemalci, vhodi in dobavitelji, aktivnosti ter namen in cilji procesa.

\section{Vloga in naloge skrbnika procesa}

Proces potrebuje nedvoumno lastništvo. Potrebuje skrbnika procesa ${ }^{22}, \mathrm{ki}$ je odgovoren za načrtovanje in izvajanje procesa ter izpolnjevanje zahtev in pričakovanj odjemalcev, tako zunanjih kot notranjih. Osnovna težava pri določanju primernega skrbnika procesa je, da meje procesa le redko sledijo mejam organizacijskih enot ter $\mathrm{s}$ tem mejam odgovornosti in pooblastil (Davenport 1993). Vpliv moči in odgovornosti funkcijskih vodij oz. vodij organizacijskih enot je vertikalen, medtem ko je vpliv moči in odgovornosti skrbnikov procesov horizontalen. Davenport optimistično

22 Angl. Process Owner. V Sloveniji ta izraz najpogosteje prevajamo v lastnik procesa ali skrbnik procesa. V nalogi uporabljamo izraz skrbnik procesa, čeprav smo v vprašalniku za empirično raziskavo ob predpostavki lažjega razumevanja uporabili izraz lastnik procesa. 
predvideva, da se bo po določenem obdobju radikalnih sprememb moč skrbnika procesa uveljavila preko funkcijskih meja.

Temeljna naloga skrbnika glavnega procesa je, da s člani tima zagotavlja uspešnost in učinkovitost procesa, $s$ čimer prispeva $k$ uspešnosti celotne organizacije. Uspešnost procesa skrbnik zagotavlja z izhodi, ki izpolnjujejo zahteve in pričakovanja odjemalcev. Učinkovitost procesa pa optimizira s poenostavljanjem postopkov in preoblikovanjem delovnih opravil, s skrajševanjem cikla procesa, z minimiziranjem stroškov, zmanjševanjem variabilnosti in avtomatizacijo procesa (DeToro in Mc Cabe 1997, 58). Skrbnik procesa je torej odgovoren za rezultate izboljšav procesa, zato mora imeti pooblastila za:

- odobritev potrebnih sprememb,

- izbor pravih sodelavcev v timu,

- določitev programa in ustrezne organizacije,

- usmerjanje, podporo in koordiniranje dela članov tima znotraj časovnih mejnikov in predvidenih rezultatov,

- zagotovitev potrebnih finančnih in drugih potrebnih virov,

- odpravljanje vrzeli med timi in zagotavljanje dogovorov v primeru medorganizacijskih sporov.

Da je skrbnik procesa osrednja oseba managementa poslovnih procesov, ugotavlja tudi Hammer (2002). Skrbnik procesa mora zagotoviti, da zaposleni razumejo proces, so primerno usposobljeni, imajo na razpolago potrebna orodja ter upoštevajo načrte in pravila. Skrbi za manjše spremembe in prilagoditve procesa novim izzivom. Seveda se Hammer ne more izogniti reinženiringu procesov. Ko pride do velikega razkoraka med dejansko in želeno uspešnostjo procesa, mora skrbnik proces zasnovati na novo, torej izpeljati projekt reinženiringa procesa.

Skrbnik procesa načrtuje proces, skrbi za njegovo udejanjanje in izboljševanje ter odgovarja za rezultate. Da bi lahko uresničeval svojo vlogo ter vplival na izvajalce procesa $\mathrm{v}$ posameznih funkcijah in njihove vodje, naj bo član vrhnjega vodstva. Tako ima možnosti vplivati tudi na druge vrhnje managerje. Za uspešno izvajanje vloge skrbnika so ključne veščine komuniciranja, še posebej v matrični organizaciji (Chang 20I I, 35).

$\mathrm{Za}$ razliko od drugih avtorjev Harmon poimenovanje odgovornega za proces in naloge izpelje iz njegovega poslanstva: management poslovnih procesov. Manager procesa izvaja managerske procese, zato planira, organizira, komunicira in nadzoruje (Harmon 2014, 138 ). Planiranje vključuje določanje ciljev procesov in pričakovanj za njihove vhode, izvajanje in izhode, pripravo načrtov in določitev razpoložljivih virov. $O r$ - 
ganiziranje vključuje zagotavljanje virov in ljudi, opredelitev nalog in odgovornosti, vzpostavitev procesov in določitev kriterijev uspeha. Naloge managerja na področju komuniciranja vključujejo komuniciranje $\mathrm{z}$ različnimi deležniki v procesih. Izvajalcem sporoča pomen aktivnosti v procesu in razvija njihovo zavezanost ter komunicira $\mathrm{z}$ vrhnjim vodstvom, managerji podpornih funkcij, odjemalci in dobavitelji. Manager procesa nadzoruje, spodbuja prizadevanja za uspešnost, ugotavlja odstopanja in sproža korektivne ukrepe.

Burlton (2015, 69-70) opozarja, da je koncept lastništva in pojem lastnika procesa enodimenzionalen, preveč enostaven in zastarel. Da bi bili procesi kot viri organizacije nenehno uspešni in učinkoviti, je potrebna cela vrsta vlog, še posebej v velikih, globalno delujočih organizacijah. Koncept upravljanja in managementa procesov je zelo kompleksen, zato so potrebne različne vloge, kot npr. vodja ${ }^{23}$ procesa, manager procesa in skrbnik procesa ${ }^{24}$. V enostavnejših organizacijah ima ena oseba lahko več vlog. V velikih organizacijah pa lahko pomembno vlogo pri upravljanju odigrajo sveti za management procesov. Ti zagotavljajo širjenje znanja, motiviranost, nadzor ter konsistentnost in usklajenost celotne arhitekture procesov.

\section{Povzetek pregleda literature}

Koncept procesov, procesne usmerjenosti in procesnega pristopa je od srede 80 -ih let dalje prinesel nove možnosti managementa organizacij. Organizacije skozi procese vsakodnevno uresničujejo svoja poslanstva, vizije in strateške usmeritve. Najpomembnejše značilnosti procesa so meje procesa, vhodi in njihovi dobavitelji, izhodi in njihovi odjemalci, aktivnosti, ki vhode transformirajo $\mathrm{v}$ izhode, namen in cilji procesa ter skrbnik procesa. Ker v večini organizacij še vedno prevladuje funkcionalna usmerjenost in organiziranost, je prepoznavanje in določitev procesov ter njihove arhitekture zelo pomemben, a zahteven prvi korak $\mathrm{v}$ udejanjanje procesne usmerjenosti. Skrbnik procesa je osrednja oseba managementa procesov. Njegova vloga vključuje načrtovanje in organiziranje procesa, komuniciranje vizije in ciljev, zagotavljanje potrebnih virov, nadzorovanje in merjenje ter ustrezno ukrepanje in izboljševanje za zagotavljanje načrtovanih rezultatov. 



\section{Upravljanje in management poslovnih procesov}

Management poslovnih procesov se je kot organizacijsko orodje za izboljševanje uveljavil v 9o-ih letih prejšnjega stoletja. Širše prepoznana so bila predvsem posamezna področja BPM, kot so nenehno izboljševanje, primerjanje in reinženiring. Šele kasneje se je uveljavilo razumevanje, da posamezni pristopi ne rešujejo samostojno vseh izzivov, zato je treba $\mathrm{k}$ BPM pristopati celovito, tudi na ravni posameznega procesa, ne le na ravni organizacije. Leta 2005 postane BPM, po raziskavi skupine Gartner, prva poslovna prioriteta managerjev (Rosemann in de Bruin 2005, 55).

Temeljne dejavnosti managerjev praviloma obsegajo načrtovanje, organiziranje, usmerjanje in nadziranje dejavnosti zaposlenih (Biloslavo 2008, 27-28). Za uspešen management procesov je potrebno zagotoviti primerno okolje, ki vzpostavlja okvir in pogoje za delovanje ter izboljševanje procesov. To je naloga upravljanja poslovnih procesov, o katerem govorimo v naslednjem poglavju.

\section{Upravljanje poslovnih procesov}

Da bi lažje razumeli namen in vsebino upravljanja poslovnih procesov, si najprej poglejmo pojem korporativnega upravljanja (angl. Corporate Governance). Pojem korporativnega upravljanja je v Sloveniji uveljavil prevod načel korporativnega upravljanja Organizacije za gospodarsko sodelovanje in razvoj (OECD) ${ }^{2}$ iz leta 2004. V Preambuli načel je poudarjen pomen korporativnega upravljanja kot enega ključnih elementov za iz-

I SSKJ: uprávljati -am nedov. (á) I. urejati, usmerjati življenje v kaki družbeni skupnosti.

2 OECD je kratica za Organisation for Economic Co-operation and Development). 
boljšanje ekonomske učinkovitosti in rasti. Opredeljena je tudi njegova vsebina:

Korporativno upravljanje sestavlja nabor odnosov med managementom družbe, njegovim odborom, delničarji in drugimi interesnimi skupinami. Korporativno upravljanje določa tudi organiziranost, ki podpira cilje družbe ter orodja za doseganje teh ciljev in spremljanje rezultatov. Dobro korporativno upravljanje mora dajati odboru in managementu prave spodbude za doseganje ciljev, ki so v interesu družbe in njenih delničarjev ter zagotavljati učinkovit nadzor. (OECD 2009, I I).

Iz zgornje opredelitve lahko izluščimo naslednje poudarke: odnosi med deležniki, organiziranost $\mathrm{v}$ podporo doseganja ciljev, prave spodbude, učinkovit nadzor in spremljanje rezultatov. Za urejanje odnosov je potrebno vzpostaviti primerna načela in pravila. Ugotovimo lahko, da je vloga korporativnega upravljanja vzpostaviti potreben okvir in pogoje za uspešno uresničevanje ciljev ter izpolnjevanje zahtev in pričakovanj deležnikov organizacije. $Z$ uporabo analogije sta torej vloga in pomen upravljanja poslovnih procesov vzpostaviti potreben okvir, zagotoviti potrebne pogoje ter nadzorovati in usmerjati management poslovnih procesov.

Avtorji funkcijo upravljanja opredeljujejo različno. Harmon (2014) meni, da je ena ključnih funkcij upravljanja procesov organiziranje. To vključuje oblikovanje politik, načel in pravil, organizacijske strukture, določitev nosilcev odločanja in ciljev. Richardson $(2006,4)$ poslanstvo upravljanja procesov vidi predvsem pri vzpostavljanju pomembnosti in transparentnosti z vidika odgovornosti in sprejemanja odločitev. Spany (2007) vidi vlogo upravljanja procesov v vzpostavitvi odgovornosti za nenehno optimiziranje in management procesov, za nadzor njihove uspešnosti in spodbujanje nenehnega izboljševanja.

Upravljanje BPM omogoča in zagotavlja, da nenehno uresničuje rezultate organizacije, ki presegajo zahteve in pričakovanja deležnikov (Kirchmer 2009, 71). Odnos med upravljanjem in managementom poslovnih procesov prikazuje slika 9.

Upravljanje poslovnih procesov mora vzpostaviti jasno hierarhijo odločanja o vseh pomembnih vprašanjih, povezanih z BPM, in to na vseh ravneh, od krovnega portfelja procesov preko programov in projektov do posameznih aktivnosti. To omogoča ustrezno in pravočasno dodeljevanje virov prioritetnim spremembam procesov in njihovo uspešno izvajanje. Upravljanje mora vzpostaviti neposredno povezavo med delovanjem procesov in strateškimi cilji organizacije ter s pravili, usmeritvami in informacijsko infrastrukturo omogočiti uspešen management procesov. 
Vzpostavitev ustreznega nadzora in kontrol pa omogoča obvladovanje skladnosti BPM (Rosemann in vom Brocke 2010, I13).

\begin{tabular}{l}
\hline \multicolumn{2}{|c|}{ Upravljanje poslovnih procesov } \\
\hline - Krovni model ključnih procesov organizacije \\
- Nedvoumno določeni krovni cilji kot osnova za KPI \\
- Odgovornosti za izboljševanje in management procesov \\
- Jasna formalna struktura za opis procesov \\
- Infrastruktura BPM \\
- Usklajen sistem priznavanja in nagrajevanje \\
- Nabor prioritet za izboljšave ključnih poslovnih procesov \\
\hline \\
$\begin{array}{l}\text { - Smernice } \\
\text { - Snovanje procesov }\end{array}$ \\
\hline informacije \\
\hline - Izvajanje procesov \\
\hline Management in obvladovanje procesov \\
\hline
\end{tabular}

Markus in Jacobsen analizirata različne koncepte upravljanja. Ti so lahko brezosebni, kot so npr. zakoni in pravila, ali pa jih izvajajo osebe z določenimi odgovornostmi in pooblastili. Avtorja obravnavata prednosti in slabosti naslednjih konceptov upravljanja: brezosebnega upravljanja, osebnega upravljanja, vertikalnih (hierarhični) pooblastil, horizontalne oziroma lateralne povezave, neformalnega upravljanja, formalnega upravljanja, pravil sodelovanja, stalnega odbora, organizacijske enote za koordinacijo procesov, prestrukturiranja organizacije, procesne organizacijske enote in procesne organizacijske strukture (Markus in Jacobsen 20I0, 2 I I-I3). Koncepti so različno uspešni in za uveljavitev zahtevajo različne napore in vlaganja. Po izkušnjah avtorjev daje najboljše rezultate primerna kombinacija enostavnejših konceptov.

Upravljanje procesov je ključna krovna aktivnost, ki uveljavlja standarde, organizacijske strukture, vloge in odgovornosti ter uveljavljene prakse merjenja, obvladovanja in izboljševanja uspešnosti managementa poslovnih procesov. Upravljanje zagotavlja, da so spremembe in izboljšave procesov skladne s strategijo in cilji organizacije, kar pomembno prispeva $\mathrm{k}$ povečevanju agilnosti organizacije (Hove, von Rosing in Storms 2015, 
600-o I). Vpetost upravljanja BPM v upravljanje organizacije, upravljanje vrednosti in uspešnosti poslovanja ter upravljanje IT-tehnologij prikazuje slika ıo.

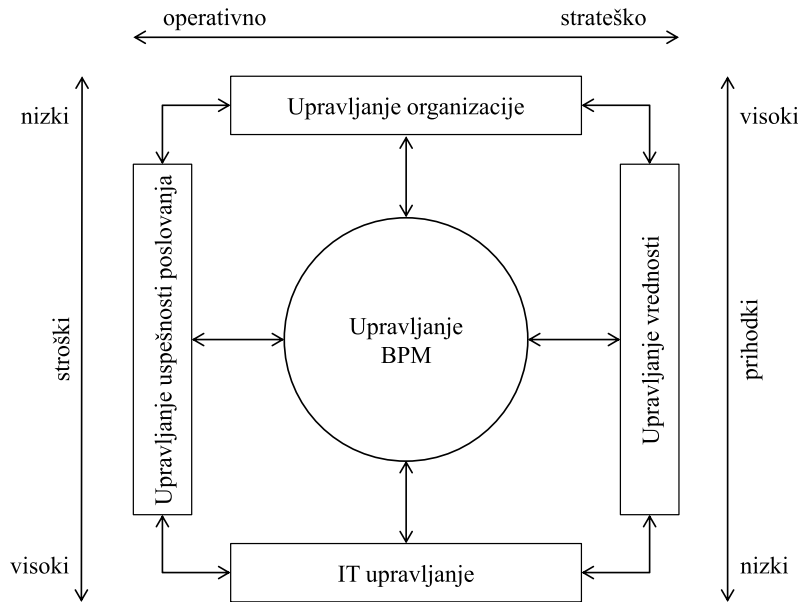

Slika Io: Umeščenost upravljanja procesov v upravljanje organizacije

Vir: LEADing Practice Governance Reference Content, po Hove, von Rosing in Storms 2015 , 600.

Naloge upravljanja procesov $\mathrm{v}$ manjših organizacijah izvajajo posamezniki. V večjih organizacijah vzpostavijo skupine, kot npr. svet za management procesov ali BPM-center odličnosti. Glavne naloge centra odličnosti so določanje prioritet in implementacija procesov, vzdrževanje portfelja procesov, uveljavljanje najboljših praks managementa procesov ter ocenjevanje njihove uspešnosti (Hove, von Rosing in Storms 2015, 603). Upravljanje procesov se izvaja na dveh ravneh, na ravni vseh procesov oziroma celotne organizacije in na ravni posameznih projektov. Strateške cilje in pobude na področju BPM določa vrhnji management. Center odličnosti znotraj tega določa prioritete projektov izboljšav v skladu z zastavljenimi cilji in pravili, usmerja izvajanje, vzpostavlja sisteme merjenja uspešnosti ter spodbuja uporabo odobrenih tehnik in orodij.

Burlton (2015) procese obravnava kot vire organizacije. Naloga upravljanja procesov je nenehno optimiziranje in management procesov, kar vključuje določanje prioritet izboljšav zmogljivosti procesov, nadzor uspešnosti delovanja in rezultatov ter obvladovanje potrebnih sprememb.

De Boer, Müller in Schwengber ten Caten (2015, 922-94) ugotavljajo, da je upravljanje poslovnih procesov kritični faktor implementacije BPM. 
Izpostavljajo naslednje vidike upravljanja: integracijo PM v management organizacije, ocenjevanje uspešnosti, dodeljevanje procesnih odgovornosti in širjenje procesne kulture. Vzrok za omejeno integracijo BPM v management organizacije tiči predvsem $\mathrm{v}$ pomanjkljivem znanju s področja BPM. Težave na področju ocenjevanja uspešnosti procesov izvirajo predvsem iz dejstva, da cilji procesov niso vedno izpeljani iz strateških ciljev organizacije, kar otežuje določitev ustreznih kazalnikov uspešnosti. Za uspešno delovanje in izboljševanje vsakega procesa mora biti nedvoumno opredeljena osebna odgovornost. Za širjenje procesne kulture je pomembno, da zaposleni razumejo pomen svojega dela za celoten proces preko organizacijskih meja in prepoznajo koristi, ki jih prinaša BPM.

\section{Management poslovnih procesov}

Koristnost uveljavljanja procesov in procesne usmerjenosti je vodila v razvoj managementa poslovnih procesov. Bergman in Klefsjö (2010, povz. po Cronemyr in Danielsson 2013, 934) vidita začetke BPM v delih gurujev TQM, kot sta Shewhart in Juran. A odgovorimo najprej na vprašanje, kaj BPM sploh je. Znanstvena in strokovna literatura ponuja številne definicije BPM. Nekaj izbranih primerov definicij BPM podaja preglednica 2.

Različni avtorji pri definiranju BPM poudarjajo različne vidike managementa procesov, npr. kakovost in osredotočenost na odjemalce, vidik IT ali pa definirajo BPM kot celosten managerski koncept. Rosemann in de Bruin $(2005,2)$ med ključnimi dejavniki BPM izpostavljata razumevanje in vključenost managementa, procesno naravnan informacijski sistem, dobro določene odgovornosti in procesom prijazno organizacijsko kulturo. BPM je treba razumeti kot celosten pristop managementa organizacije, ki sloni na procesni arhitekturi in povezanosti procesov s strategijo, cilji ter politikami organizacije. Zahteva ustrezno upravljanje in osredotočenost zaposlenih na odjemalce.

Melan je že v 8o-ih letih opredelil šest značilnosti managementa poslovnih procesov: vzpostavitev skrbništva, določitev meja procesa, opredelitev procesa, vzpostavitev kontrolnih točk, izvajanje meritev in izvedbo korektivnih ukrepov za odpravo odstopanj (Melan 1985). 
BPM je strukturiran pristop, ki uporablja metode, politike, metrike, managerske prakse in $S W^{1}$-orodja za obvladovanje ter nenehno optimiziranje aktivnosti in ciljev organizacije.

Gartner report 2005, cit. po Hove, von Rosing in Storms 2015, 599

Uresničevanje ciljev organizacije z izboljševanjem, managementom in obvladovanjem ključnih poslovnih procesov.

Jeston in Nelis 2007, II

Uporaba orodij in tehnik za določitev, oblikovanje, dokumentiranje, načrtovanje, izvajanje, merjenje, vzdrževanje in izboljševanje procesov.

$\mathrm{OMG} 2008,464$

BPM vključuje koncepte, metode in tehnike za podporo načrtovanju, upravljanju, oblikovanju, izvajanju in analiziranju poslovnih procesov.

Weske 20I2,5

Način organiziranja kakovostnega dela s ciljem povečevanja zadovoljstva kupcev in zniževanja stroškov, kar posledično izboljša dobičkonosnost organizacije.

Cronemyr in Danielson 2013,943

BPM se nanaša na širok pristop managementa procesov organizacije. Pogosto vključuje prizadevanja za usklajevanje različnih procesnih pristopov, kot so vitkost, šest sigma, preoblikovanje procesov, izboljševanje uspešnosti zaposlenih, sprejemanje odločitev,

BPTrends 2013 poslovna pravila in različni načini avtomatizacije.

De Toro in McCabe $(1997,56)$ management procesov prepoznavata kot nov pristop $\mathrm{k}$ managementu organizacij, ki omogoča njihov uspeh $\mathrm{v}$ konkurenčnem okolju. Ker odlični procesi zagotavljajo odločilne, trajnostne konkurenčne prednosti, mora biti cilj BPM sistematično izboljševanje vseh procesov, še posebej tistih, ki so bistveni za preživetje organizacije. Avtorja procese dojemata kot strateško sredstvo organizacije, podobno kot so to patenti in intelektualna lastnina, blagovne znamke, lastni izdelki, geografske lokacije in ključni zaposleni.

Življenjski cikel BPM vključuje izvajanje naslednjih nalog: določitve, modeliranja, analize, izboljšav, vpeljave, izvedbe, nadzora in spremembe procesa. Toda management poslovnih procesov je treba razumeti kot širši koncept in celoviteje kot management zmogljivosti organizacije (Rosemann in vom Brocke 2010, I09). Na osnovi študij izbranih zrelostnih modelov (DeToro in McCabe 1997; Luftman 2003; Maulli idr. 2003; Harmon 2003 in 2004; Rummler-Brache 2004; Curtis idr. 2004; OMG 2008; Rosemann in de Bruin 2005; de Bruin 2009; SEI 2006; Hammer 2007; cit. po Rosemann in vom Brocke 20IO, I IO) sta avtorja predvsem na osnovi modelov Rosemanna in de Bruina prepoznala šest kritičnih elementov BPM: strateško povezanost, upravljanje, metode, informacijsko tehnologijo, ljudi in kulturo. Vsak od teh šestih elementov predstavlja kritičen dejavnik uspeha BPM. Zato morajo v organizacijah, ki želijo vzpostaviti uspešen management poslovnih procesov, vsakega od njih skrbno 
obravnavati in razvijati. Elementi so podrobneje razčlenjeni v področja zmogljivosti, ki jih obravnavamo nekoliko kasneje v razdelku 3.2.2.

Raynus (201 I, 62-65) poudarja potrebo po sistematičnem pristopu $\mathrm{k}$ izboljševanju uspešnosti poslovanja in razvijanju agilnosti organizacije. Njegov okvir kvantitativnega managementa uspešnosti delovanja ${ }^{3}$ vsebuje 8 zaporednih korakov, in sicer:

I. razviti in prečistiti skupno strategijo,

2. določiti kritične faktorje uspeha ${ }^{4}$,

3. določiti in kvantificirati strateške cilje,

4. določiti ključne kazalnike uspešnosti poslovanja',

5. vzpostaviti meritve,

6. nenehno izboljšsevati procese,

7. določiti prioritete in obvladovati tveganja ter

8. sprejemati odločitve na osnovi uravnoteženih kazalnikov.

Šesti korak, nenehno izboljševanje procesov, vključuje najprej jasno sliko obstoječih procesov in prepoznavanje potencialnih področij za izboljšave. Sledijo prepoznavanje in opredelitev dejanskih vzrokov za ozka grla, odločitev glede potrebnih izboljšav in modeliranje izboljšanega procesa. Zaključna aktivnost je opredelitev potrebnih virov za nenehno izboljševanje.

Management poslovnih procesov lahko povečuje konkurenčne prednosti organizacije le, če ga izvajamo celostno skozi procesno usmerjeno delovanje. Spreminjanje ukoreninjene funkcijske miselnosti v procesno usmerjenost je dolgotrajen proces soočanja z najrazličnejšimi odpori. $\mathrm{Ob}$ tem BPM vključuje številne deležnike, od odjemalcev, dobaviteljev, zaposlenih do lastnikov. Vse to zahteva vrsto kompetenc in veliko sodelovanja. BPM vključuje sestavine managementa drugih vsebin, npr. managementa sprememb, IT-managementa in projektnega managementa. Celosten pogled na management poslovnih procesov prikazuje slika I I. 


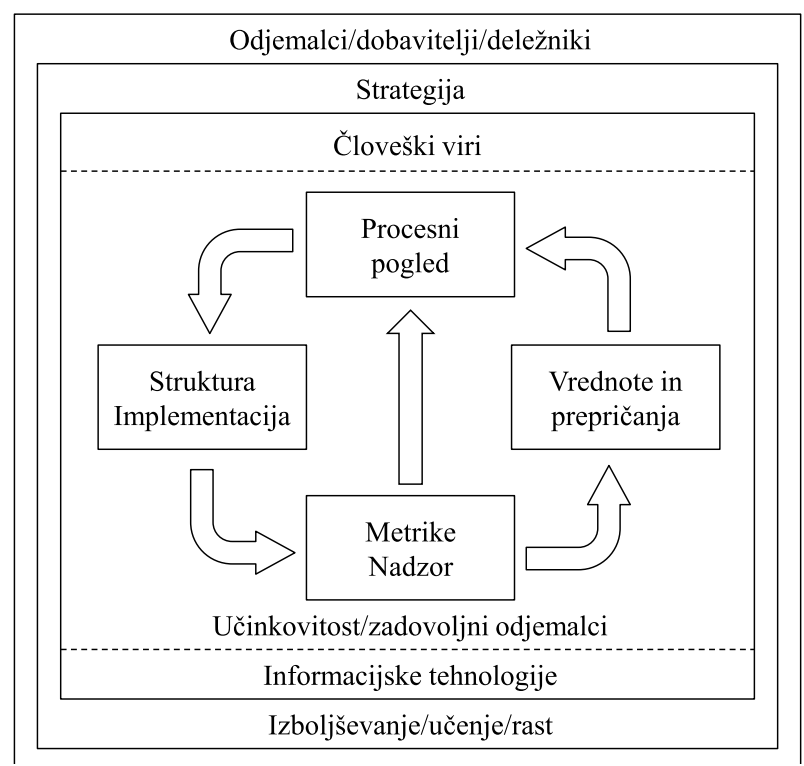

Slika ı г: Celosten pogled na BPM

Vir: Willaert idr. 2007, 4.

Burlton (2006) na podlagi dolgoletnih izkušenj na področju BPM opredeli ro temeljnih načel, sam jih imenuje tudi dobre prakse:

I. spremembe poslovanja morajo biti usmerjene v poslovno uspešnost,

2. spremembe poslovanja morajo temeljiti na zahtevah in pričakovanjih deležnikov,

3. odločitve o spremembah morajo biti sledljive do meril deležnikov,

4. za usklajeno izvajanje sprememb mora biti organizacija razčlenjena vzdolž linij poslovnih procesov,

5. poslovne procese je treba managerirati celostno,

6. pobude za preoblikovanje procesov morajo navdihniti širši vpogled,

7. pobude za preoblikovanje procesov morajo biti upravljane od zunaj,

8. pobude za preoblikovanje procesov je potrebno $\mathrm{v}$ določenih časovnih obdobjih ponavljati,

9. poslovne spremembe so predvsem ljudje in

Io. poslovne spremembe so potovanje, ne cilj. 
Kljub široki uveljavljenosti BPM pa pristopi v praksi niso vedno uspešni. Spany (2007, 174-75) vidi več razlogov za to. Prvi razlog prepoznava v dejstvu, da je večina BPM-literature zelo tehnično naravnana. Drugi razlog vidi v tem, da je premalo poudarjen pomen miselnosti in vedenja vodij. To, kako zaposleni dojemajo svojo organizacijo in klimo v njej, je v 50 do 70 \% odvisno od dejanj vodij (Goleman, Boyatzis in McKee 2002, po Spany 2007, 175). Za uspešen začetek managementa procesov je torej potrebna vključenost vodstva, za uspešno nadaljevanje pa je potrebno vključiti celotno organizacijo in vse zaposlene.

\section{Življenjski cikel managementa poslownih procesov}

Številni avtorji management poslovnih procesov naslanjajo na koncept življenjskega cikla. Koncept življenjskega cikla izdelka so razvili v ameriški avtomobilski in letalski industriji, sloni pa na fazah življenja v naravi, ki potekajo od rojstva, skozi faze odraščanja in zrelosti, do umiranja. Management življenjskega cikla izdelkov in storitev je tako s tehničnega kot $s$ tržnega in prodajnega vidika še danes temelj uspešnega poslovanja organizacij v privatnem sektorju.

$\mathrm{V}$ akademskem in raziskovalnem svetu, pa tudi v praksi, obstaja vrsta konceptualizacij in vizualizacij življenjskega cikla managementa poslovnih procesov. Chang $(2006,44)$ življenjski cikel izboljševanja procesov opredeli v 8 korakih, in sicer:

I. določi cilje organizacije,

2. preglej vse procese organizacije,

3. rangiraj procese glede na njihov prispevek $\mathrm{k}$ ciljem organizacije, razpoložljive primerjave in finančne vire, ki so na voljo za izboljšave,

4. izberi proces, ki bo najbolj prispeval $\mathrm{k}$ dodani vrednosti,

5. določi način in pristope izboljševanja (postopno ali radikalneje),

6. izvedi projekt izboljšave procesa,

7. nadzoruj in meri proces ter

8. ponovi korak 4 .

De Morais s skupino avtorjev v svoji študiji analizira 3 I strokovnih člankov na temo življenjskega cikla BPM (De Morais idr. 20I4) in za nadaljnjo analizo izbere 7 modelov življenjskega cikla (Van der Aalst 2004; Netjes idr. 2006; Zur Muehlen in Ho 2006; Weske 2007; Hallerbach idr. 2008; Verma 2009; Houy idr. 2010, cit. po De Morais idr. 2014, 419-26). Obravnavane modele analizirajo z vidika razlik in podobnosti z ABPMP- 
${ }^{6}$-okvirom BPM in z Burltonovim pristopom uresničevanja strategije skozi procese. Razlike oziroma pomanjkljivosti obravnavanih modelov se kažejo predvsem v fazi načrtovanja, v premajhni povezanosti arhitekture procesov oziroma BPM s strategijo organizacije ter v zaključni fazi izpopolnjevanja procesov. Za odpravo teh slabosti avtorji predlagajo razširjen koncept življenjskega cikla BPM s poudarkom na strategiji (slika I 2).

Burlton (2015, 64) uporabo koncepta življenjskega cikla razširi tudi na odnose z deležniki (od nepoznavanja do prenehanja odnosov) in na vire organizacije (od ideje do prenehanja uporabe). Med temi skrajnostmi se izdelki in storitve, odnosi in viri nenehno spreminjajo in vstopajo v zrelejša obdobja. Prav poslovni procesi so tisti, ki omogočajo te spremembe in razvoj.

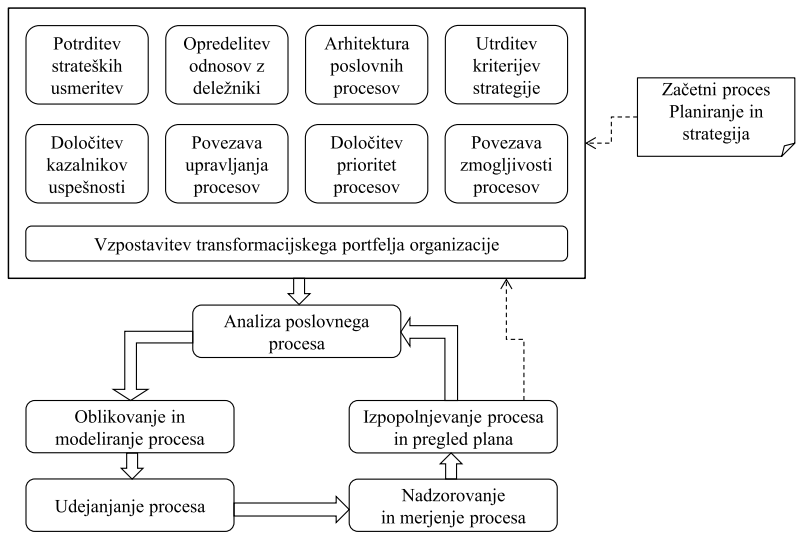

Slika I2: Razširjen okvir BPM s poudarkom na strategiji

Vir: De Morais idr. 2014, 427

\section{Cilji in zmogljivost poslownih procesov}

Da bi poslovni procesi lahko podpirali poslanstvo, vizijo, cilje in strategije organizacije, morajo razvijati svoje zmogljivosti. Naloga upravljanja procesov je, da strategije organizacij poveže z managementom procesov, določi pričakovane rezultate in iz njih izpelje cilje procesov ter prioritete izboljšav. Na osnovi določenih pričakovanj glede prihodnje uspešnosti procesov je mogoče analizirati vrzeli $v$ zmogljivostih procesa ter opredeliti potrebne ukrepe in izboljšave. V splošnem lahko kakršne koli razlike med obstoječim in želenim stanjem obravnavamo kot problem. Da pa bi

6 ABPMP Association of Business Process Management Professionals je mednarodno neprofitno združenje strokovnjakov BPM, ki razvija in promovira znanje BPM. 
znali sprejemati prave odločitve glede potrebnih izboljšav, moramo razumeti naravo problema. Šele takrat bomo sposobni sprejemati prave ukrepe za razvijanje zmogljivosti, kar bo omogočilo doseganje želenih rezultatov (Harmon 2014, 19I). Povezanost sedanje in prihodnje zmogljivosti ter uspešnosti procesov avtor prikaže z modelom vrzeli (slika I3).

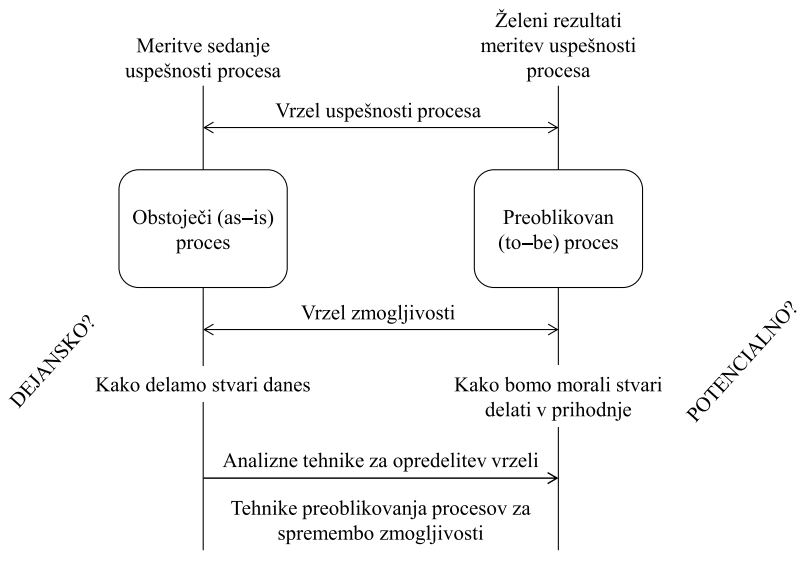

Slika I 3 : Model vrzeli

Vir: Harmon 2014, 193.

Tudi Davenport je že pred časom opozarjal, da morajo biti cilji procesov izpeljani iz strategije organizacije (Davenport 1993, I28-29). Cilje procesov je treba določati merljivo, tako glede delovanja procesov kot potrebnih sprememb.

Teorije strateškega managementa poudarjajo, da je treba strategijo organizacije prevesti v strategije poslovnih procesov. Med uveljavljene pristope razširjanja strategije gotovo sodi sistem uravnoteženih kazalnikov. Strateške cilje BSC in pripadajoče kazalnike obravnava s štirih vidikov: eden od teh vidikov je vidik notranjih procesov (Van Looy 2014, 58).

CMMI zmogljivost procesa definira kot razpon oziroma območje rezultatov, ki jih je skozi proces mogoče doseči (CMMI 2010, 487). Zmogljiv proces je torej proces, ki lahko izpolnjuje določeno kakovost izdelka ali storitve in uresničuje cilje procesa (CMMI 2010, 474).

Zmogljivosti procesa, $v$ literaturi pogosto srečamo tudi izraz področja zmogljivosti procesa, avtorji opredeljujejo različno. Že v uvodu v razdelek 3.2 smo omenili Rosemanna in vom Brockea ter njunih šest kritičnih elementov BPM: strateško povezanost, upravljanje, metode, informacijsko tehnologijo, ljudi in kulturo. Avtorja vsakega od teh elementov razdelita na 5 področij zmogljivosti, prikazanih v preglednici 3 . 


\begin{tabular}{|c|c|c|c|c|c|}
\hline Elementi BPM & & & odročja zmogljive & & \\
\hline $\begin{array}{l}\text { Strateška pov- } \\
\text { ezanost }\end{array}$ & $\begin{array}{l}\text { Načrtovanje iz- } \\
\text { boljševanja pro- } \\
\text { cesov }\end{array}$ & $\begin{array}{l}\text { Povezava strate- } \\
\text { gije in zmogljivo- } \\
\text { sti procesov }\end{array}$ & $\begin{array}{l}\text { Arhitektura pro- } \\
\text { cesov organi- } \\
\text { zacije }\end{array}$ & $\begin{array}{l}\text { Meritve pro- } \\
\text { cesov }\end{array}$ & $\begin{array}{l}\text { Odjemalci in } \\
\text { deležniki pro- } \\
\text { cesov }\end{array}$ \\
\hline Upravljanje & $\begin{array}{l}\text { Sprejemanje } \\
\text { odločitev o man- } \\
\text { agementu pro- } \\
\text { cesov }\end{array}$ & $\begin{array}{l}\text { Procesna pravila } \\
\text { in odgovornosti }\end{array}$ & $\begin{array}{l}\text { Povezovanje ka- } \\
\text { zalnikov in us- } \\
\text { pešnosti pro- } \\
\text { cesov }\end{array}$ & $\begin{array}{l}\text { S procesi poveza- } \\
\text { ni standardi }\end{array}$ & $\begin{array}{l}\text { Skladnost man- } \\
\text { agementa pro- } \\
\text { cesov }\end{array}$ \\
\hline Metode & $\begin{array}{l}\text { Snovanje in } \\
\text { modeliranje pro- } \\
\text { cesov }\end{array}$ & $\begin{array}{l}\text { Uvajanje in izva- } \\
\text { janje procesov }\end{array}$ & $\begin{array}{l}\text { Nadzorovanje } \\
\text { in kontrola pro- } \\
\text { cesov }\end{array}$ & $\begin{array}{l}\text { Izboljševanje in } \\
\text { inoviranje pro- } \\
\text { cesov }\end{array}$ & $\begin{array}{l}\text { Management } \\
\text { programov in } \\
\text { projektov }\end{array}$ \\
\hline $\begin{array}{l}\text { Informacijska } \\
\text { tehnologija }\end{array}$ & $\begin{array}{l}\text { Snovanje in } \\
\text { modeliranje pro- } \\
\text { cesov }\end{array}$ & $\begin{array}{l}\text { Uvajanje in izva- } \\
\text { janje procesov }\end{array}$ & $\begin{array}{l}\text { Nadzorovanje } \\
\text { in kontrola pro- } \\
\text { cesov }\end{array}$ & $\begin{array}{l}\text { Izboljševanje in } \\
\text { inoviranje pro- } \\
\text { cesov }\end{array}$ & $\begin{array}{l}\text { Management } \\
\text { programov in } \\
\text { projektov }\end{array}$ \\
\hline Ljudje & $\begin{array}{l}\text { Procesne veščine } \\
\text { in ekspertna } \\
\text { znanja }\end{array}$ & $\begin{array}{l}\text { Znanje manage- } \\
\text { menta procesov }\end{array}$ & $\begin{array}{l}\text { Usposabljanje na } \\
\text { področju pro- } \\
\text { cesov }\end{array}$ & $\begin{array}{l}\text { Sodelovanje v } \\
\text { procesih }\end{array}$ & $\begin{array}{l}\text { Voditelji v man- } \\
\text { agementu pro- } \\
\text { cesov }\end{array}$ \\
\hline Kultura & $\begin{array}{l}\text { Odzivnost na } \\
\text { spremembe pro- } \\
\text { cesov }\end{array}$ & $\begin{array}{l}\text { Vrednote in } \\
\text { načela, povezana } \\
\text { s procesi }\end{array}$ & $\begin{array}{l}\text { Odnos do pro- } \\
\text { cesov in vedenje }\end{array}$ & $\begin{array}{l}\text { Posluh vodij za } \\
\text { management } \\
\text { procesov }\end{array}$ & $\begin{array}{l}\text { Socialna omrež- } \\
\text { ja managementa } \\
\text { procesov }\end{array}$ \\
\hline
\end{tabular}

Vir: Rosemann in vom Brocke 2010, I I 2

Za potrebe naše raziskave je zanimiv pogled na zmogljivosti procesov oziroma širše procesne usmerjenosti vsaj še dveh avtorjev, Škrinjarja (2010) in Van Looya (2014). Njuno razumevanje obravnavamo v razdelku 4.2 Procesna usmerjenost in delovanje organizacije.

Sočasen strateški in organizacijski pristop $\mathrm{k}$ managementu procesov ima lahko velik sinergijski učinek na njegovo uspešnost. Organizacije, ki strategijo povezujejo z BPM in vzpostavijo ustrezno organizacijsko strukturo z BPM-enoto in uveljavljeno vlogo skrbnikov procesov, so uspešnejše pri zagotavljanju učinkovitosti procesov, kakovosti izdelkov in storitev ter agilnosti. Kljub pomenu povezovanja strategije in procesov oziroma izpeljevanja ciljev procesov iz strateških ciljev organizacije rezultati zadnje raziskave v Sloveniji in na Hrvaškem kažejo, da kar 75 \% vključenih organizacij k BPM ne pristopa strateško (Hernaus, Vukšić in Štemberger 20I6, I5-I6). Tako visoka številka je primerljiva s stanjem v Avstriji, Nemčiji in Švici, kjer se številne organizacije ukvarjajo z BPM, a le manjši del k BPM pristopa celovito in udejanja procesno zasnovano organizacijo ( $\mathrm{Ne}$ ubauer, 2009, povz. po Hernaus, Vukšić in Štemberger 2016, 15). 
$S$ ciljem obvladovanja procesa mora skrbnik procesa sprejemati ustrezne odločitve glede vrste pomembnih vprašanj, npr. parametrov procesa, zagotavljanja potrebnih virov in odpravljanja morebitnih odstopanj. Zato mora vzpostaviti primerne kontrolne točke, nadzor in merjenje procesa, ki mu zagotavljajo relevantne in verodostojne povratne informacije o delovanju in rezultatih procesa. Merjenje procesa CMMI $(2010,488)$ definira kot nabor aktivnosti, ki so potrebne za določanje vrednosti meritev procesa ter izdelkov in storitev, da bi razumeli značilnosti procesa.

Številni avtorji poudarjajo pomen merjenja procesov. Nekateri merjenje uvrstijo celo $v$ definicijo managementa poslovnih procesov (OMG 2008,464 ), drugi ga prepoznavajo kot pomemben element managementa poslovnih procesov, kot zmogljivost procesov oziroma BPM ali kot kategorijo zrelostnih modelov (Melan 1985; Willaert idr. 2007; Rosemann in vom Brocke 2010; Škrinjar 2010; CMMI 20II; De Morais idr. 2014; Bergholtz in Danielsson 2012, povz. po Cronemyr in Danielsson 2013). Nedvoumna vključitev merjenja in analiziranja v zrelostni model CMMI kot razlikovalno procesno področje managementu omogoča potrebno preglednost in osredotočenost pri uporabi meritev za izboljševanje procesov (Goldenson, Jarzombek in Rout 2003).

Pomanjkanje pravih meritev je pogosto največja ovira za izboljševanje procesov. Meritve in dober sistem nagrajevanja posameznike in skupine $\mathrm{z}$ motivirajo a dodatne napore, ki presegajo običajna prizadevanja. Toda meritve same po sebi še niso dovolj. Potrebno je vzpostaviti konsistenten sistem povratnih informacij, ki posameznikom in skupinam omogoča odzivanje na informacije ter odpravljanje odstopanj in problemov (Harrington I991, 164). Najprimernejša oseba za izvajanje meritev je izvajalec aktivnosti, saj je tako omogočena takojšnja povratna informacija tistemu, ki delo tudi najbolje razume (Harrington 1991, 170).

Meritve procesov so lahko notranje, znotraj verige vrednosti ali procesa, oziroma zunanje. Med notranje najpogosteje sodijo meritve uspešnosti in učinkovitosti, cikla trajanja procesa in kakovosti delnih, notranjih izhodov procesa. Med zunanje meritve sodijo npr. meritve kakovosti izhodov procesa, zadovoljstva odjemalcev in drugih deležnikov, meritve odzivov trga in tržnih deležev (Harmon 20I4, I I2). Merjenje zadovoljstva odjemalcev z izhodi procesa je najverjetneje najpomembnejša meritev katerega koli procesa (Davenport 1990, cit. po McCormack 2007, 32).

Harmon poudarja pomen razumevanja razlik med kazalniki z vidika njihove sporočilnosti. Za sprejemanje odločitev so zelo pomembni kazalniki delovanja, ki nakazujejo potrebe po ukrepanju. Takšne kazalnike 
avtor poimenuje vodilni kazalniki ${ }^{7}$. Druga skupina kazalnikov kaže na dosežene rezultate, $k i j i h$ ni več mogoče spreminjati. Te kazalnike rezultatov poimenuje kazalniki s časovno zakasnitvijo ${ }^{8}$ (Harmon 20I4, I I 2-I3).

Zaradi množice meritev na različnih področjih in ravneh je pomembno, da organizacija vzpostavi celovit sistem merjenja, ki konsistentno povezuje strateške cilje organizacije in cilje deležnikov s cilji procesov. Eden od bolj uveljavljenih sistemov merjenja je že obravnavani sistem uravnoteženih kazalnikov BSC (Harmon 2014, II4-I5).

Nedavna študija literature $s$ področja sistemov merjenja uspešnosti procesov $^{9}$ (Wieland idr. 2015, 328) je pokazala, da v literaturi še niso objavljeni pristopi za oblikovanje integriranega, celostnega sistema merjenja uspešnosti procesov. Omenjena študija tako predstavlja prvi pristop $k$ oblikovanju priporočil za razvoj celostnega, h kupcu usmerjenega sistema merjenja uspešnosti procesov.

Razširimo vsaj na kratko naš pogled $\mathrm{z}$ merjenja uspešnosti procesov na merjenje poslovne uspešnosti organizacije kot celote. To področje $\mathrm{v}$ zadnjih letih doživlja izjemno hiter razvoj tako sistemov kot metodologij, od sistema uravnoteženih kazalnikov in številnih izpeljank tega sistema preko ekonomske dodane vrednosti in ekonomskega dobička, $\mathrm{ABC}^{10}$ do modelov za samoocenjevanje, npr. modela odličnosti EFQM (Kennerley in Neely 2005, 150-53). Avtorja v svojem sistemu, ki ga imenujeta prizma uspešnosti poslovanja, v središče postavljata zadovoljstvo deležnikov organizacije. Uspešnost uresničevanja zadovoljstva deležnikov je odvisna od prave strategije, procesov, skozi katere se strategija uresničuje, in zmogljivosti, ki podpirajo to delovanje. Zadnji vidik je prispevek deležnikov $\mathrm{k}$ uspešnosti organizacije (njihova lojalnost in dobičkonosnost). Dober sistem kazalnikov uspešnosti poslovanja mora vsebovati uravnotežen nabor kazalnikov vseh navedenih vidikov.

\section{Izboljševanje in inoviranje procesov"}

Harmon poudarja potrebo po sistematičnem obvladovanju sprememb procesov. Spremembe morajo biti ustrezno načrtovane in izvedene na vseh treh nivojih: na nivoju organizacije, na procesnem nivoju in na iz-

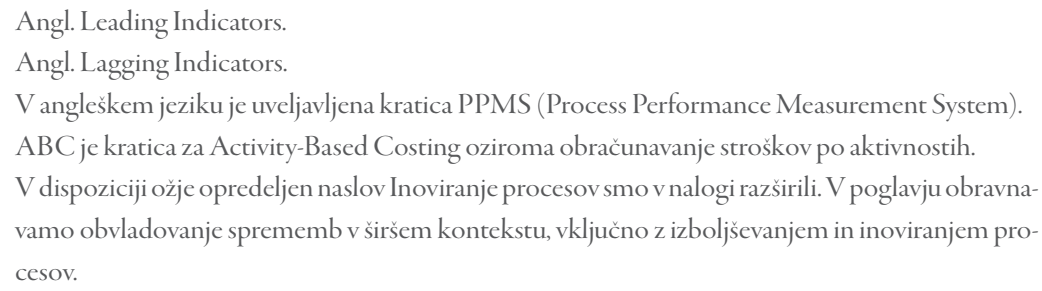


vedbenem nivoju, ki vključuje tudi zagotavljanje potrebnih virov (Harmon 2014, 54). Spremembe procesov so predvsem posledica spremenjenih strateških ciljev, strategij in načrtov organizacije. Zato je za uspešno spreminjanje procesov na nivoju organizacije pomembno razumeti poslovni kontekst, ustrezno definirati arhitekturo procesov, določiti potrebne meritve, vzpostaviti upravljanje in povezati zmogljivosti procesov. Vse to oblikuje okvir uspešnega managementa procesov (slika I4).

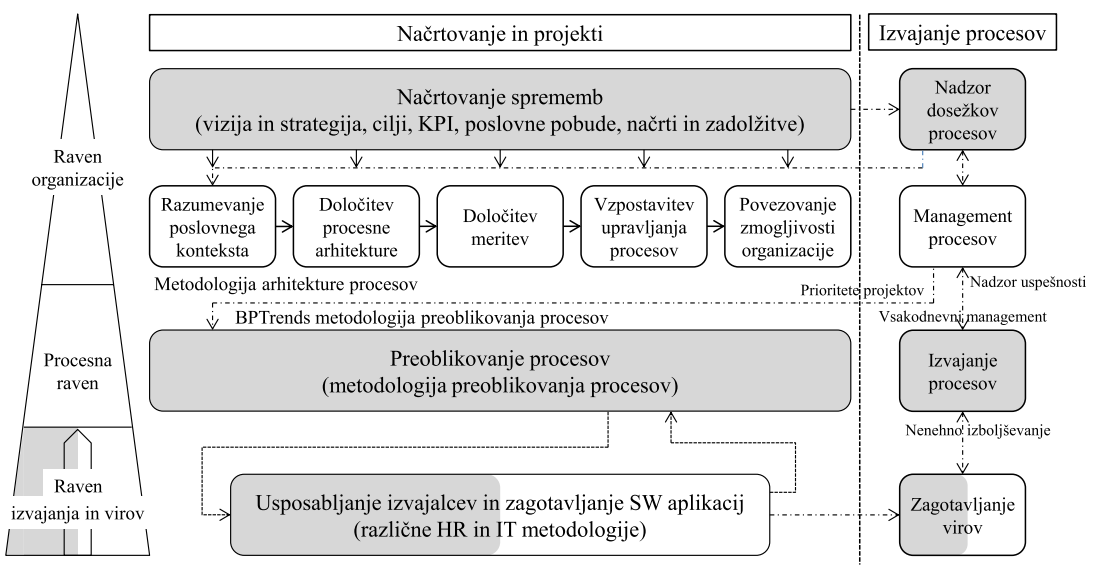

Slika I4: BPTrends metodologija obvladovanja sprememb procesov

Vir: Harmon 2014, 54.

\section{Kaj in zakaj izboljševati}

Pri načrtovanju sprememb pa se logično najprej zastavita vprašanji, katere procese sploh spreminjati in na kakšen način. Kot osnovo za izbiro prave poti izboljševanja procesov DeToro in McCabe $(1997,59)$ predlagata ocenjevanje stanja procesa $\mathrm{z}$ vidika njegove uspešnosti in učinkovitosti. $\mathrm{Na}$ osnovi ocenjevanja $z$ uporabo 5 -stopenjske lestvice opredelita naslednje stopnje oziroma stanja procesa: Nezdrav, Nekonkurenčen, Konkurenčen, Najboljši v panogi in Svetovni razred (slika Is).

$\mathrm{V}$ praksi se pogosto pojavi potreba po izboljšavah več procesov. Ker pa so viri običajno omejeni, je izboljšave smotrno izvajati po prioritetah. Eden možnih kriterijev za določanje prioritet je največji donos ob najmanjšem naporu (Lehman 2012, I 40). Kot osnovo za odločanje Lehman predlaga matriko za ocenjevanje kompleksnosti procesa, ki lahko vključuje naslednje splošne dimenzije: cilje procesa, poslovno klimo, finančna tveganja, tehnične zahteve, organiziranost, tehnologijo, nujnost, geografske razsežnosti, kompetence članov tima in pričakovane koristi. 
Učinkovitost

Notranja ocena

Proces je brez napak, stroški na enoto so nizki, ni izgub, nizki stroški slabe

kakovosti

4 izgube majhne, čas cikla je bil skrajšan

Proces se izvaja precej učinkovito, a ima priložnosti za izboljšave glede

3

trajanja cikla in stroškov na enoto

2

Proces je neučinkovit in potrebuje

2 izboljšave

Proces ima velike težave zaradi okvar, na enoto, zaposlenih in postopkov ter

1 stroškov slabe kakovosti
Proces je učinkovit, stroški so nizki, izgub, dolgih ciklov, visokih stroškov

Stanje procesa

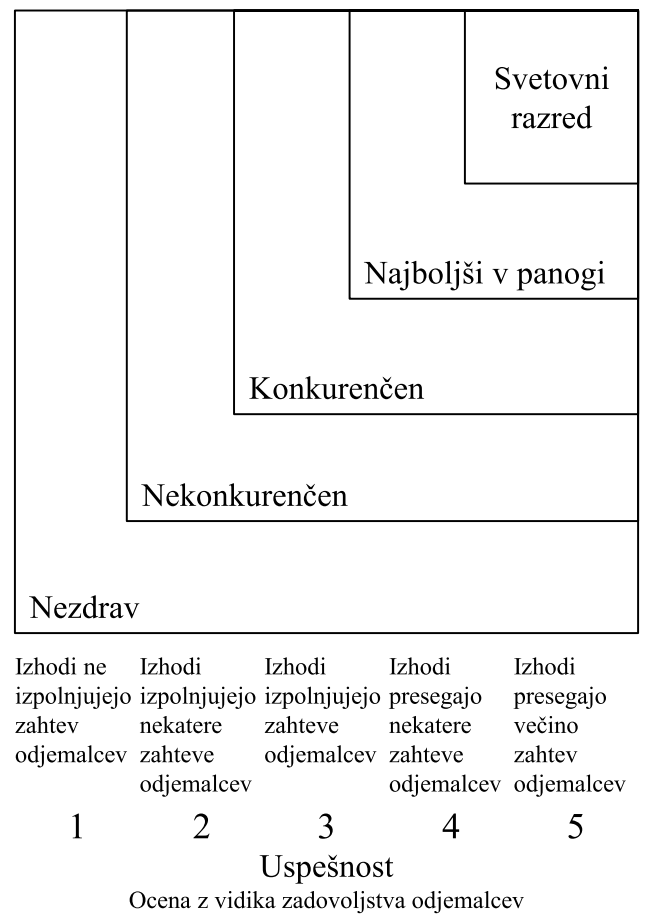

Slika i s: Ocenjevanje uspešnosti in učinkovitosti procesa

Vir: DeToro in McCabe 1997, 59.

Ob tem je seveda pomemben tudi način, na katerega bomo posamezen proces izboljšali. Za Harmona sta najpomembnejša kriterija za izbor primernega načina izboljševanja strateška pomembnost ter kompleksnost in dinamičnost procesov (Harmon 2003, 83; Harmon 2014, 165). Za enostavnejše in statičnejše procese, ki pa izdelkom ali storitvam dodajajo visoko vrednost in so strateško zelo pomembni, je najprimernejše postopno izboljševanje (slika I6). Primeri takšnih procesov so npr. proizvodnja ali izvajanje storitev, realizacija naročila ali v bolnišnici zdravljenje pacientov. Pogosto uporabljena metodologija izboljševanja je 6s. Za kompleksnejše, a strateško pomembne procese je primernejši način izboljševanja njihova avtomatizacija z namensko izdelano programsko opremo. Primer takšnih procesov je proces vodenja proizvodnje, prenosa ali distribucije električne energije. Enostavnejše procese, ki ne dodajajo veliko vrednosti in so strateško manj pomembni, organizacije pogosto avtomatizirajo 
$\mathrm{z}$ uvajanjem ERP-sistemov ${ }^{12}$ ali sistemov za management odnosov z odjemalci $\left(\mathrm{CRM}^{13}\right)$. Tipični primeri takšnih procesov so npr. finančni in računovodski procesi, nabavni procesi in podpora odnosov $\mathrm{z}$ odjemalci. Zelo kompleksni in dinamični procesi, ki so tudi strateško zelo pomembni, npr. proces razvoja novih izdelkov, sklepanje poslov ali odločanje o investicijah, pa zahtevajo samostojne projekte preoblikovanja. Kadar pa takšni dinamični procesi, bolj ali manj kompleksni, nimajo velikega vpliva na uresničevanje strategije, lahko organizacija njihove izboljšave zaupa zunanjim izvajalcem, specializiranim za izvajanje teh procesov (outsourcing). Primeri takšnih procesov so npr. logistični procesi ali zagotavljanje prehrane zaposlenim.

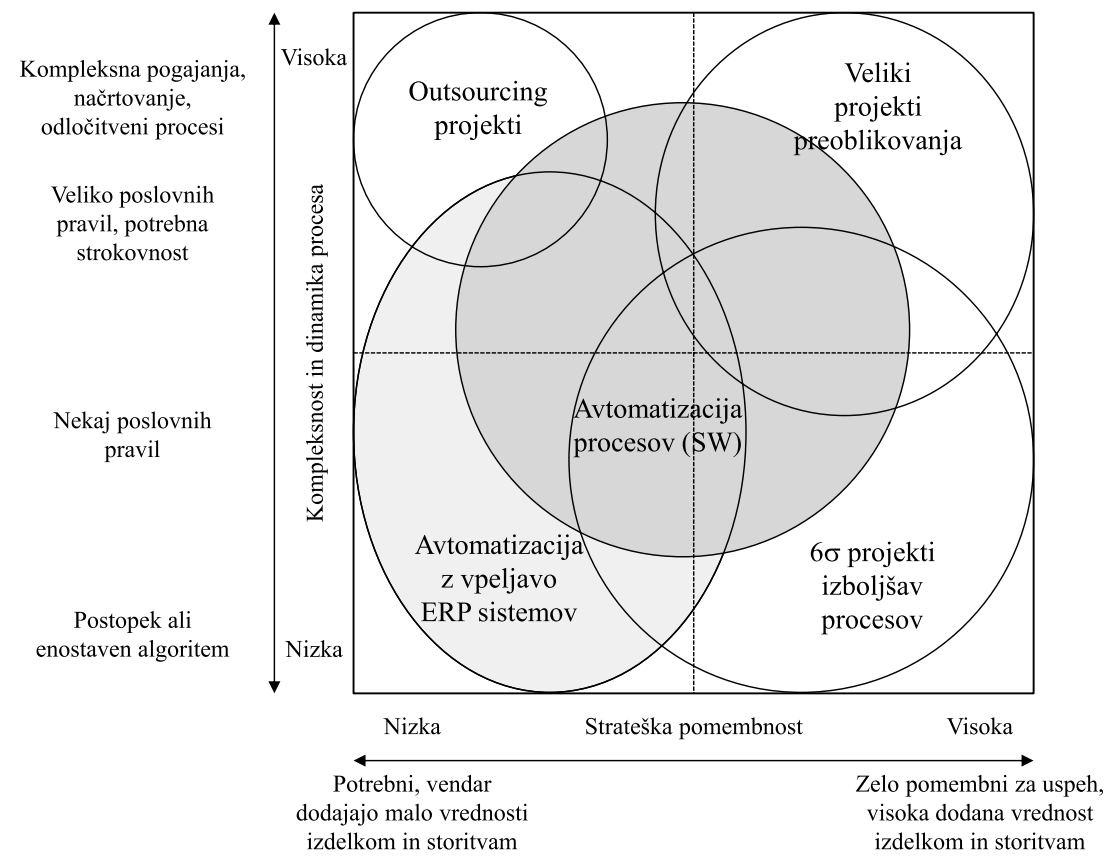

Slika 16: Analiza kompleksnosti in strateške pomembnosti procesa

Vir: Harmon 2014, 165

I 2 ERP je široko uveljavljena kratica za poslovno-informacijski sistem (angleško Enterprise Resource Planning).

I 3 CRM je kratica za Customer Relationship Management. 


\section{Izboljševanje procesov}

Zaradi potreb po vse večji konkurenčnosti in zadovoljevanju vedno višjih zahtev in pričakovanj odjemalcev Harrington (I99I, I5) izpostavlja 3 glavne cilje izboljševanja procesov:

- uspešnost procesov - zagotoviti želene rezultate,

- učinkovitost procesov - minimizirati porabo virov in

- prilagodljivost procesov - sposobnost hitrega prilagajanja spremembam zahtev odjemalcev in poslovanja.

Za uspešno izboljševanje je potrebno (Harrington 1991, 25):

- zagotoviti podporo vodstva,

- biti dolgoročno naravnan,

- disciplinirano uporabljati metodologijo,

- določiti skrbnika procesa,

- vzpostaviti meritve in povratne zanke ter

- biti osredotočen na proces.

Na osnovi izkušenj v IBM Harrington (I991, 23) predlaga 5 faz izboljševanja poslovnih procesov, in sicer:

I. organiziranje za izboljšavo,

2. razumevanje procesa,

3. poenostavitev in racionalizacija,

4. merjenje in nadzor ter

5. nenehno izboljševanje.

Poenostavitve in racionalizacije procesov lahko z majhnimi vložki velikokrat prinesejo velike učinke, seveda takrat, ko sta zagotovljena ustrezna podpora vodstva in izbran ustrezen pristop izboljševanja. Harrington za uspešno poenostavitev in racionalizacijo procesov predlaga zaporedje desetih osnovnih postopkov oziroma orodij, ki ga prikazuje slika 17.

Sharp in McDermott opredelita metodologijo izboljševanja procesov $\mathrm{v}$ treh fazah (Sharp in McDermott 2009, 84). Uspešen projekt izboljšav procesa po njunem mnenju vključuje:

I. vzpostavitev konteksta, obsega in ciljev procesa,

2. razumevanje poteka procesa as-is in drugih dejavnikov ter

3. določitev karakteristik in zahtev procesa to-be.

Posebno pozornost posvetita prvi fazi projekta izboljšav. Nedvoumna umestitev procesa, ki je potreben izboljšav, $\mathrm{v}$ arhitekturo procesov, jasna določitev meja obravnavanega procesa in odgovornosti zanj, prepoznava- 
nje deležnikov procesa ter njihovih zahtev in pričakovanj ter določitev ciljev izboljšav lahko preprečijo marsikateri kasnejši problem.

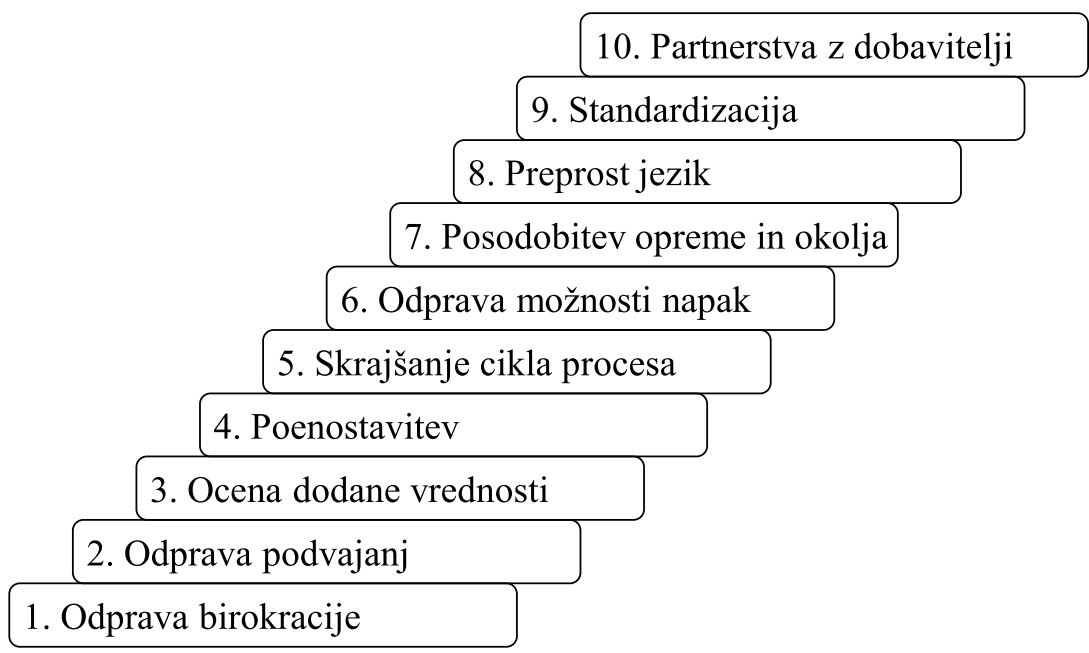

Slika i7: Osnovni postopki izboljševanja procesov

Vir: Harrington 1991, I 32.

Odločitveni model, ki sloni na analizi prispevka vrednosti procesa, ponuja nov, svež pristop $\mathrm{k}$ izboljševanju procesov (Bolsinger idr. 2015, 373). Avtorji iščejo način za izboljševanje procesa, ki bi slonel na ekonomskih kriterijih in ne bi posegal v njegovo strukturo. Odločitev o tem, kako izboljšati proces, sloni na izbiri najprimernejše poti skozi proces, ki najbolj poveča ekonomski učinek procesa. Avtorji svoje delo naslanjajo na to, da imajo različne izbire in poti skozi proces različen vpliv na denarni tok. Predlagani model so pilotno preizkusili na procesu preverjanja vrstnega reda naročil v organizaciji, ki se ukvarja z distribucijo IT-opreme.

Čeprav govorimo o izboljševanju procesov, se moramo zavedati, da je vsaka izboljšava tudi sprememba. Spremembe pa so lahko uspešne le, ko vključujejo spreminjanje rigidnosti organizacijskih struktur in odpravljanje ideoloških predsodkov birokracije v organizacijah (Hamel 20r4). Da bi organizacije razvijale svojo agilnost, mora preoblikovanje sloneti na naslednjih načelih (Van den Bergh idr. 2016):

- močna notranja in zunanja povezanost,

- občutljivost za moteče trende na eni in priložnosti na drugi strani, 
- prilagodljive strukture in hitre linije odločanja o strateških projektih,

- osredotočenost na odjemalce kot del kulture ter

- zgled in zavezanost vodij.

\section{Inoviranje procesov}

Nenehno inoviranje vsega, na vseh ravneh, je osnova za trajnostno strateško prednost (Peters in Austin 1985, I14). Resnični svet inoviranja je poln naključnih srečnih odkritij in nabit $s$ strastjo. $V$ procesu inoviranja so ključni dejavniki eksperimentiranje in poskušanje, vneti zagovorniki in decentralizirane skupine. Naloga vodij $\mathrm{v}$ inovativnih organizacijah je, da ustvarjajo organizacijsko klimo, ki spodbuja eksperimentiranje in ustvarjanje zagovornikov. Ed Schon iz MIT $^{14}$ (cit. po Peters in Austin 1985, 135) poudarja pomen zagovornikov nove ideje: »Nova ideja ali najde zagovornika ali pa umre. Običajno navdušenje nad novo idejo ne zagotavlja potrebne energije za soočanje z ravnodušnostjo in odpori, ki jih sprožajo spremembe.«

Novih idej ne potrebujemo samo za nove izdelke in storitve, ampak tudi za nove načine organiziranja in delovanja ter drugačno razumevanje stvari in odnosov. Za nove ideje potrebujemo kreativnost. De Bono (2006) poudarja, da kreativnost ni poseben talent, ki bi ga imeli samo izbranci, ampak je veščina, ki se jo je možno naučiti, jo razvijati, vaditi in uporabljati. Zato potrebujemo neobičajno oziroma lateralno razmišljanje kot nujno dopolnitev logičnega, vertikalnega razmišljanja. Lateralno razmišljanje se ukvarja s spreminjanjem ustaljenih vzorcev ter odnosa do informacij in njihove uporabe. Glavni namen lateralnega razmišljanja je izzivalna uporaba informacij in nato spodbijanje sprejetih konceptov (De Bono 2006, 136). Še posebej učinkovito je pri generiranju novih idej in reševanju problemov.

Inoviranje procesov je primeren način za transformiranje organizacij in izboljševanje njihove uspešnosti (Davenport 1993, 299). Razlikovati ga moramo od izboljševanja procesov. Če izboljševanje procesa pomeni postopno povečevanje uspešnosti in učinkovitosti obstoječega procesa, pa inoviranje pomeni izvajanje aktivnosti na radikalno nov način. Davenport je razlike med izboljševanjem in inoviranjem procesov predstavil na način, kot je prikazan $\mathrm{v}$ preglednici 4 . 


\begin{tabular}{lll}
\multicolumn{1}{c}{ Značilnost } & \multicolumn{1}{c}{ Izboljševanje } & \multicolumn{1}{c}{ Inoviranje } \\
Stopnja spremembe & Postopna & Radikalna \\
\hline Izhodišče & Obstoječ proces & Čista tabla \\
\hline Pogostost sprememb & Enkratna/nenehna & Enkratna \\
\hline Potreben čas & Kratek & Dolg \\
\hline Sodelovanje & Od spodaj navzgor & Od vrha navzdol \\
\hline Tipičen obseg & Ozek, znotraj funkcij & Sirok, preko funkcij \\
\hline Tveganje & Zmerno & Visoko \\
\hline Primarni dejavnik & Statistična kontrola & Informacijska tehnologija \\
\hline Vrsta spremembe & Vedenjska & Vedenjska/strukturna \\
\hline
\end{tabular}

Vir: Davenport 1993, I I.

Inoviranje procesov mora potekati v kontekstu strateških usmeritev organizacije, z jasno vizijo prihodnjega stanja. Za uspešno inoviranje je potreben jasen pristop, ki vključuje celoten življenjski cikel inoviranja od izbire procesov za preoblikovanje, preko temeljite in strukturirane obravnave dejavnikov inoviranja, oblikovanja vizije, razumevanja obstoječega procesa do zasnove novega procesa. Vodstvo mora zagotoviti vse potrebne vire, pri čemer so za uspešno inoviranje najpomembnejše informacije in informacijske tehnologije ter ljudje (Davenport I993, 299-302).

Management poslovnih procesov s širokim naborom uveljavljenih metod in modelov na različne načine uspešno povečuje konkurenčnost organizacij. Nove tehnologije digitalne dobe, vključno z informacijski$\mathrm{mi}$, ponujajo številne možnosti inoviranja procesov (Schmiedel in vom Brocke 2015). Dinamika inoviranja procesov se razlikuje od dinamike inoviranja izdelkov in storitev (slika 18 ). Avtorja razliko pojasnita na primeru mobilnih telefonov. Ob njihovem pojavu so proizvajalci na trgu tekmovali z množico inovacij. Čez čas se je dinamika inovacij na tem področju močno upočasnila. Pri inoviranju procesov je dinamika obratna. V začetnem obdobju so se mobilni telefoni uporabljali predvsem za komuniciranje, kasneje in še danes pa številne funkcije pametnih telefonov odpirajo vedno nove možnosti uporabe v najrazličnejših procesih povsod po svetu. 


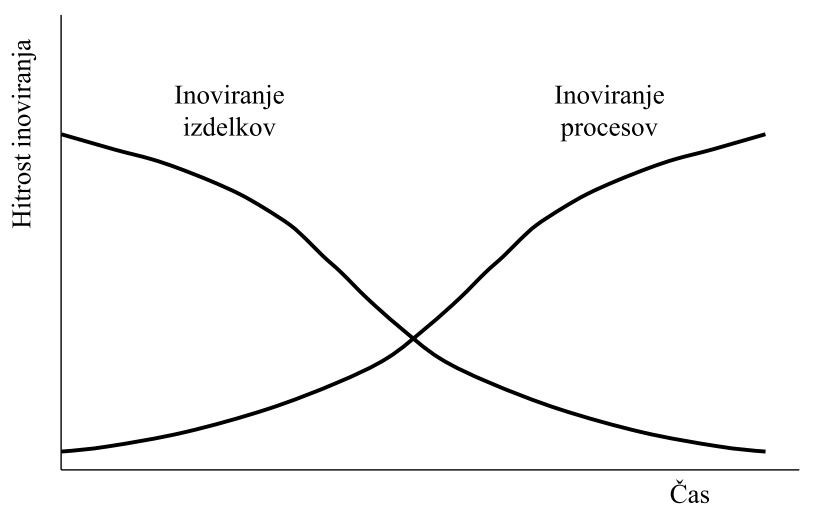

Slika ı 8: Dinamika inoviranja izdelkov in procesov

Vir: Schmiedel in vom Brocke 20 1 5, 6.

Inovacije izdelkov se porajajo s perspektive proizvajalcev. Osredotočene so na razvoj in širjenje uporabe izdelkov ter pogosto vključujejo nove tehnologije. Inovacije procesov pa se porajajo s perspektive uporabnikov. Osredotočajo se na uporabo novih izdelkov in pogosto zahtevajo spreminjanje vedenjskih vzorcev med posamezniki ter organizacijami (Schmiedel in vom Brocke 2015, 6).

BPM torej lahko razumemo kot vir inoviranja. To svojo vlogo izvaja na dva načina. Po eni strani se osredotoča na management ustvarjalnih procesov ter tako spodbuja razvoj in inoviranje izdelkov ter storitev. Po drugi strani pa se osredotoča na management projektov preoblikovanja procesov, ki prinaša tudi inovacije procesov (Schmiedel in vom Brocke 2015, 6).

Sodobne informacijske in komunikacijske tehnologije, kot so mobilne platforme, obdelava v oblaku in socialna omrežja, omogočajo vključevanje odjemalcev in drugih deležnikov $\mathrm{v}$ izvajanje procesov ter $\mathrm{v}$ razvijanje novih izdelkov in storitev. Management in inoviranje procesov se, še posebej v storitvenih dejavnostih, vse bolj osredotočata na zunanje procese organizacije (Vom Brocke in Schmidel 2015, 9).

\section{Uveljavljene metodologije izboljševanja procesov}

Številne organizacije, ki si prizadevajo za nenehno izboljševanje svojih procesov, uporabljajo metodologijo šest sigma ${ }^{15}$, vitko organizacijo ${ }^{16}$ ali kombinacijo obojega. Vitki pristop in šest sigma sta sledili samostojni

I 5 Angl. Six Sigma (6s).

I6 Angl. Lean Organization. 
poti vse do 8o-ih let dvajsetega stoletja. Prva raba vitke proizvodnje je bila zabeležena v tovarni Ford v Michiganu leta 1913, nato pa so jo dokončno razvili na Japonskem v okviru Toyotiniga proizvodnega sistema (TPS). Medtem ko je šest sigmo razvil inženir Bill Smith v ZDA, v okviru raziskovalnega središča Motorola v sredini 8o-ih let dvajsetega stoletja (Antony 201 I; Laureani, Brady in Antony 2013).

Obe metodologiji sta kompleksni in zaslužita ločeno obdelavo, kar presega namen naše raziskave. Ker pa gre za široko uporabljani metodologiji izboljševanja procesov ter obvladovanja sprememb proizvodnih in storitvenih procesov, si zaslužita vsaj kratko omembo tudi v okviru naše monografije.

\section{Šest sigma - $6 \sigma$}

Šest sigma (6s) je strukturiran pristop ali metodologija na osnovi spremljanja podatkov, ki omogoča prepoznavanje problematičnih področij poslovanja, določanje projektov izboljšav in izvajanje prebojnih izboljšav na predvidljiv ter ponovljiv način (Redinius 2004, 4). Snee (1999) jo opredeljuje kot poslovno strategijo, ki si prizadeva za prepoznavanje in odpravljanje vzrokov napak ali pomanjkljivosti v poslovnih procesih ter se osredotoča na rezultate, ki so ključnega pomena za odjemalce (Laureani, Brady in Antony 2013). Metodologija preoblikovanja poslovanja 6s povečuje vrednost za odjemalce in maksimira dobiček. Osredotoča se na zmanjševanje variabilnosti in odpravljanje napak $s$ pomočjo statističnih orodij in tehnik (Skalle in Hahn 2013, 15). O razvoju metodologije 6s v Motoroli v poznih 8o-ih letih smo kratko spregovorili že uvodoma $\mathrm{v}$ razdelku 2.I. Metodologija sloni na statističnih tehnikah (npr. načrtovanje eksperimentov, analiza variance (ANOVA), statistični nadzor procesa (SPC), analiza vzrokov in posledic, histogrami itd.) merjenja delovanja procesov za zmanjševanje variabilnosti procesov (Antony 20II). Sigma je v statistiki oznaka za standardno deviacijo. Šest sigma pomeni kar 99,99966-odstotno vključenost vseh deviacij oziroma le 3,4 možnih napak na milijon izdelkov oziroma ponovitev procesa.

6s-projekte izboljšav vodijo usposobljeni trenerji. Glede na svoje kompetence nosijo nazive po pasovih v borilnih veščinah (zeleni pas, črni pas in črni pas mojster). Projekti potekajo po metodologiji DMAIC ${ }^{17}$, ki vključuje 5 faz izboljševanja: določi, meri, analiziraj, izboljšaj in nadzoruj. Metoda DMAIC je skladna z Demingovim krogom nenehnih izboljšav

I7 DMAIC je akronim za faze v metodologiji izboljševanja: Define - Measure - Analyze - Improve Control. 
PDCA (Antony 2011; Arumugam, Antony in Douglas 2012). V začetni fazi vsakega 6s-projekta za reševanje prepoznanega problema je potrebno izdelati model SIPOC ${ }^{18}$ in določiti korake procesa. Diagram poteka predstavlja analitični okvir, ki omogoča prepoznavanje aktivnosti, ki so pripeljale do obravnavanega problema. Ko je problem na ta način enkrat lokaliziran, je njegovo reševanje običajno omejeno le na ta del procesa.

Hammer zagovarja stališče, da je $6 \mathrm{~s}$ del managementa procesov in je tesno povezan s celovitim obvladovanjem kakovosti (TQM). Zato morajo organizacije, da bi potenciale $6 \mathrm{~s}$ izkoristile v čim večji meri, projekte umestiti v širši kontekst BPM (Hammer 2002, 32). BPM zagotavlja najširši okvir celovitosti in koordinacije izboljševanja, saj odkriva problematična področja $\mathrm{v}$ celotni arhitekturi procesov, $6 \mathrm{~s}$ pa predstavlja metodologijo in nabor orodij za izvedbo izboljšav (Redinius 2004, 6-7).

\section{Vitka organizacija}

Metodologija vitkih procesov in organizacije se uporablja za dostavo izdelkov in storitev bolje, hitreje in z nižjimi stroški. Vitka proizvodnja in kasneje vitka organizacija izvirata iz nabora načel in pristopov, razvitih na osnovi Toyotinega proizvodnega sistema ${ }^{19}$. Metodologija sloni na nenehnem osredotočanju na vrednost za odjemalca in skrajševanju cikla izdelave izdelka oziroma izvedbe storitve. Glavna orodja in tehnike vključujejo stabilne in standardizirane metode dela (npr. 5 S, standardizacija dela, zmanjšanje pretočnih časov, JIT, SMED, proizvodnja brez napak, kanban), zaradi česar so vključeni vsi zaposleni, ki se osredotočajo na tisto, kar odjemalec resnično želi, to je primerna kakovost, ob pravem času in z minimalnimi stroški (Antony 20I I; Andersson idr. 20I4). Vitkost procesov in skrajševanje časov je mogoče uresničevati z brezkompromisnim odpravljanjem kakršnih koli izgub. Taiichi Ohno, oče TPS, prepoznava 7 vrst izgub (Hines idr. 201 2, 6):

I. čezmerno proizvodnjo,

2. napake,

3. nepotrebne zaloge,

4. neustrezno obdelavo,

5. čezmeren transport,

6. čakanje in

7. nepotrebno gibanje.

I8 SIPOC je kratica za model procesa v verigi dobavitelj - vhod - proces - izhod - odjemalec (angleško Supplier - Input - Process - Output - Customer).

19 Angl. Toyota Production System ali TPS. 
Kasneje drugi avtorji, predvsem Womack, Bicheno in Holweg (povz. po Skalle in Hahn 2013, I 4) dodajo še druge vrste izgub:

- izgube, povezane z učinkovito izdelavo napačnih izdelkov,

- neizkoriščen človeški kapital,

- čezmerne informacije in komunikacije,

- izgube naravnih virov in

- izgubljen delovni čas zaradi nujnega reševanja problemov oziroma »gašenja požarov«(reaktivno delovanje).

Hines poudarja pomembnost 5 načel odpravljanja izgub (Hines idr. 201 2, 4; Deblois in Lepantu 2016; Womack in Jones 2003):

I. opredelite vrednost $\mathrm{z}$ vidika kupca,

2. opredelite tok materiala in informacij,

3. izdelajte tok aktivnosti za ustvarjanje vrednosti,

4. proizvajajte na podlagi dejanske porabe kupca in

5. stremite $\mathrm{k}$ popolnosti.

Avtor opozarja, da je vitkost težje ohranjati kot vzpostaviti. Dejavniki, ki omogočajo ohranjanje vitkosti, so: strategija in uskladitev, voditeljstvo, vedenje in angažiranost, management procesov ter tehnologija, orodja in tehnike (Hines idr. 2012, I4).

\section{Vitka šest sigma ${ }^{20}$}

V sodobni praksi sta vitki pristop in šet sigma dve izmed najpriljubljenejših metodologij, ki omogočata stalno izboljševanje tako v proizvodnih kot v storitvenih dejavnostih, vključno z javnim sektorjem. Koristi vzporedne uporabe obeh pristopov so navedene $\mathrm{v}$ številnih študijah primerov $s$ področja proizvodnje in storitev. $\mathrm{V}$ praksi se obravnavani metodologiji vse pogosteje uporabljata skupaj. Šest sigma z zmanjševanjem variabilnosti in odpravljanjem napak izdelkov ter storitev povečuje predvsem uspešnost in zadovoljstvo odjemalcev. Vitkost pa z odpravljanjem izgub, osredotočanjem na aktivnosti z največjo dodano vrednostjo in skrajševanjem časovnega cikla povečuje predvsem učinkovitost procesov. Sočasna in povezana uporaba obeh metodologij torej povečuje uspešnost in učinkovitost procesov, razvija njihovo odličnost, povečuje zadovoljstvo odjemalcev in omogoča rast organizacije (Skalle in Hahn 2013, 16; Womack in Jones 1996, povz. po Bhat, Gijo in Jnanesh 2014).

Metodologiji povezuje tudi spoznanje, da se v praksi preprosto skoraj ni mogoče ločeno ukvarjati samo s kakovostjo ali samo s hitrostjo. Potre- 
ben je uravnotežen pristop, ki organizacijam omogoča, da z najkrajšimi procesi izboljšujejo kakovost izdelkov in storitev, ki jo določajo odjemalci. Vzajemno delovanje in vplivanje obeh metodologij se kaže tudi v doseženem donosu na investiran kapital ${ }^{21} \mathrm{v}$ projekte izboljšav (Raynus 201 I, 223).

Vitka metodologija obravnava izgube $\mathrm{v}$ vseh procesih in se osredotoča na hitrost ter čas, medtem ko se strategija šet sigma osredotoča na načrtovanje, odpravljanje napak, odpravo variabilnosti procesov kot tudi zmanjšanje stroškov. Metodologija šet sigma daje dodatno vrednost vitki metodologiji, saj odpravlja variabilnost v času. Čas odpreme tako postane zanesljivejši in zniža se raven varnostnih zalog. Tako skupna raba vitke metodologije šest sigma ponuja rešitev, ki ustvarja prilagodljivejše, zanesljivejše in stroškovno učinkovitejše procese (Assarlind, Gremyr in Bäckman 2013; Christensen, Germain in Birou 2007; Dahlgaard in Dahlgaard-Park 2006; Andersson idr. 2014).

Celostni pristop vpliva na dolgoročne rezultate. V nadaljevanju navajamo nekaj podobnosti med vitko metodologijo in metodologijo šest sigma za izboljšave in management procesov (Antony 201 I):

- Obe metodologiji sta osredotočeni na procese in uresničevanje potreb ter pričakovanj odjemalcev.

- Obe potrebujeta podporo managementa za uspešnost, predvsem $\mathrm{v}$ smislu ustvarjanja infrastrukture in zagotavljanja sredstev ter potrebnega časa za spreminjanje organizacijske kulture.

- Lahko sta uporabljeni tako $\mathrm{v}$ proizvodnji kot $\mathrm{v}$ storitveni dejavnosti.

- Obe uporabljata multidisciplinarne skupine za reševanje poslovnih problemov.

- Obe nudita komplementarni sklop orodij, ki skupaj in z drugimi najboljšimi praksami upravljanja ponujajo celovit način za preoblikovanje podjetja z izboljšavami operativne učinkovitosti do operativne odličnosti.

$\mathrm{V}$ nadaljevanju je nekaj temeljnih razlik med vitkim pristopom in pristopom šest sigma za izboljšave in management procesov (Antony 2OII):

- Uporaba metodologije šest sigma zahteva intenzivnejše usposabljanje v primerjavi z vitko metodologijo. 
- Vpeljava metodologije šest sigma je povezana z višjimi stroški kot pa vpeljava vitke metodologije.

- Vitka metodologija se $\mathrm{v}$ osnovi uporablja za reševanje vprašanj neučinkovitosti procesa medtem ko se šest sigma uporablja predvsem za reševanje vprašanj uspešnosti procesa.

- Šest sigma bo odpravila napake v procesih, vendar ne bo obravnavala vprašanja optimiranja procesnega toka. V nasprotju s tem vitka načela niso v veliko pomoč pri doseganju visoke zmogljivosti in visoke procesne stabilnosti.

Albliwi idr. (2014) so prepoznali 34 vplivnih dejavnikov za uspešno izvajanje vitke šest sigme in orodij za izboljševanje. Večina podjetij pri uvajanju metodologij ni pozorna na kritične dejavnike uspeha, kot so: zavezanost in vključenost vrhnjega managementa, sprememba organizacijske kulture, komunikacija $\mathrm{z}$ zaposlenimi $\mathrm{v}$ operativi, usposabljanje in izobraževanje, izbira projektov in prednostno razvrščanje nalog, viri, povezave med projekti in strateškimi cilji organizacije itd. (Albliwi idr. 2014).

Številni avtorji so dokazali, da obstajajo podobne prakse med vitko šest sigma, šest sigma, vitko metodologijo in TQM (Näslund 2008; Andersson, Eriksson in Torstensson 2006; Bendell 2006; Zu, Robbins, in Fredendall 20ro, povz. po Hilton in Sohal 2012). Postavlja se vprašanje, kako vključiti čim več ljudi, tj. ne samo uvajalce vitke šest sigme, za premagovanje miselnih ovir z uporabo metode DMAIC za vsakodnevne izboljšave na delovnem mestu (Wiklund in Wiklund 2002, povz. po Hilton in Sohal 2012).

\section{Vpliv sodobnih tehnologij in orodij}

Sodobne informacijske in komunikacijske tehnologije in orodja odpirajo skoraj neslutene možnosti razvijanja sistemov, ki omogočajo sprejemanje odločitev in delovanje $\mathrm{v}$ realnem času. Naprave za radiofrekvenčno identifikacijo (RFID) ${ }^{22}$ in senzorske tehnologije, vgrajene $\mathrm{v}$ proizvode, že omogočajo povezovanje senzorjev, ki beležijo dogodke, npr. neposredno v proizvodnji, s proizvodnimi informacijskimi sistemi, ERP-sistemi in podatkovnimi skladišči. To skrajšuje čas med informacijo o dogodku v proizvodnji in odločanjem v zvezi s tem dogodkom. Potrebne transformacije poslovanja za pameten proizvodni proces prikazuje preglednica 5 . Nove 
tehnologije, kot je internet stvari (IoT) $)^{23}$, pozornost vodstev organizacij od proizvodnje oziroma izvajanja storitev širijo na celoten življenjski cikel izdelka ali storitve. Možnosti povezovanja velikega števila objektov in stvari v samostojno delujoča omrežja prinašajo čisto nove storitve in procese. In prav tu postane inoviranje poslovnih procesov osrednji dejavnik potrebnih transformacij poslovanja (Møller 2015, 27).

Razvoj interneta stvari je omogočil zbliževanje in povezovanje različnih tehnologij, sistemov in storitev: brezžičnih tehnologij, mikroelektromehanskih sistemov, mikrostoritev in interneta. To povezovanje odpravlja pregrade med silosi operativnih in informacijskih tehnologij, kar omogoča prenos nestrukturiranih strojno generiranih podatkov kot osnovo za analiziranje, obvladovanje procesov, njihovo izboljševanje in inoviranje (IoT Agenda 2016).

Široka uporabnost in priložnosti, ki jih prinašata tehnologiji mobilnosti in obdelav v oblaku, predstavljajo velik izziv za inoviranje storitev in poslovnih procesov. Tehnologiji se lahko uporabljata samostojno, a se $\mathrm{v}$ praksi pogosto uporabljata $\mathrm{v}$ povezavi. Obe sodita med transformacijske tehnologije, saj odpirata in demokratizirata dostop do informacij (Kemsley 2015, 52). Mobilnost je prevladujoč trend za razvijanje uporabniških aplikacij na številnih področjih, od npr. informacije o prihajajočem avtobusu na postajališču do zdravniškega nadzora bolnika, ki je v domači oskrbi. Informacije, shranjene v oblaku, pa omogočajo dostopnost od praktično koder koli. Kemsley obravnava tudi vpliv konceptov Big Data ${ }^{24}$ in poslovne analitike. Nove tehnologije pa spreminjajo tudi naravo dela. Enostavna, rutinska dela so vse bolj avtomatizirana, medtem ko kompleksna opravila, ki so nepredvidljiva in vsebujejo tveganja, ostajajo ljudem. Avtorica opozarja na razvoj socialnih poslovnih aplikacij, ki jih omogočajo nastajajoče nove strukture in procesi (Kemsley 2015, 52).

23 Internet stvari (angleško Internet of Things ali IoT) je sistem medsebojno povezanih računalniških naprav, mehanskih in digitalnih naprav, predmetov, živali ali ljudi, ki so opremljeni z enoličnimi identifikatorji in omogočajo prenos podatkov prek omrežja brez interakcije človek človek ali človek - računalnik. $\mathrm{V}$ praksi že najdemo številne primere uporabe $\mathrm{IoT} v$ različnih panogah, npr.v zdravstvu, energetiki, logistiki, kmetijstvu in gradbeništvu (IoT Agenda 2016).

24 Poslovenjeno bi ta koncept lahko poimenovali velike količine podatkov ali velike zbirke podatkov. 


\begin{tabular}{lll}
\multicolumn{1}{c}{ Iz } & \multicolumn{1}{c}{ V } \\
$\begin{array}{l}\text { Vlaganje v objekte in } \\
\text { opremo }\end{array}$ & $\begin{array}{l}\text { Vlaganje v znanje, ob- } \\
\text { jekte in opremo }\end{array}$ & $\begin{array}{l}\text { Investicije in management objektov ter opreme in znanja so ena- } \\
\text { ko pomembni. }\end{array}$ \\
\hline Reaktivno & Proaktivno & $\begin{array}{l}\text { Optimizacija ekonomike je dosežena na osnovi predvidevanj in } \\
\text { odločitev, upoštevajoč verjetnost, tveganja in učinke. }\end{array}$ \\
\hline Odzivanje & Preventiva & $\begin{array}{l}\text { Uporaba zaznavanja, modeliranja in analiziranja za napovedo- } \\
\text { vanje poslovnih dogodkov. Krmiljenje delovanja za zmanjševan- } \\
\text { je vplivov. }\end{array}$ \\
\hline Skladnost & Uspešnost poslovanja & $\begin{array}{l}\text { Nič okoljskih, zdravstvenih in varnostnih incidentov je del } \\
\text { poslovne kulture. }\end{array}$ \\
\hline Taktično & Strateško & $\begin{array}{l}\text { Zahteve postanejo priložnosti. Optimiziranje celotnega poslo- } \\
\text { vanja organizacije. }\end{array}$ \\
\hline Lokalno & Globalno & \begin{tabular}{l} 
Vsaka odločitev mora biti sprejeta v kontekstu globalnega okolja. \\
\hline
\end{tabular} \\
\hline
\end{tabular}

Vir: Smart Process Manufacturing Engineering Virtual Organization Steering Committee 2009,7 .

Zaradi velike popularnosti in množične uporabe socialnih omrežij Trkman in Klun (2015, 59) analizirata različne načine njihove uporabe $\mathrm{v}$ inoviranju procesov. Socialna omrežja ponujajo številne možnosti vključevanja mnenj in idej različnih deležnikov, tako znotraj organizacije kot izven nje, $v$ različnih fazah življenjskega cikla procesa. $Z$ odpiranjem širokega, odprtega prostora ustvarjalnosti in sodelovanja prinašajo socialna omrežja v strukturirane procese potrebno fleksibilnost.

\section{Povzetek pregleda literature}

Kljub različnim pristopom in konceptom upravljanja procesov so si avtorji enotni, da je upravljanje izjemno pomembno za uspešnost managementa poslovnih procesov, saj vzpostavlja pogoje ter skozi usmeritve in nadzor nenehno zagotavlja pričakovane rezultate procesov v podporo uresničevanju strategije organizacije. BPM je treba razumeti kot celosten pristop in integralni del managementa organizacije, ki sloni na procesni arhitekturi in povezanosti procesov s strategijo, cilji in politikami organizacije. Vzroki za omejeno integracijo tičijo tudi v pomanjkljivem znanju s področja managementa poslovnih procesov. Ključni dejavniki uspešnega uveljavljanja BPM so razumevanje in vključenost vodstva, nedvoumno določeno in razumljeno skrbništvo procesov, pravi kazalniki za merjenje uspešnosti procesov, procesom prijazna organizacijska kultura ter procesno naravnan informacijski sistem. Za širjenje procesne kulture 
je pomembno, da zaposleni razumejo pomen svojega dela za celoten proces, preko organizacijskih meja, in prepoznajo koristi, ki jih prinaša BPM. Težave na področju merjenja in ocenjevanja uspešnosti procesov izvirajo predvsem iz dejstva, da cilji procesov niso vedno izpeljani iz strateških ciljev organizacije, kar otežuje določitev ustreznih kazalnikov uspešnosti. BPM se v praksi potrjuje kot primeren način za inoviranje in transformiranje organizacij ter razvijanje njihove agilnosti. Vendar BPM kot managerska disciplina tudi sam potrebuje spremembe, ki jih v največji meri narekuje hiter razvoj informacijskih in komunikacijskih tehnologij. 


\section{Procesno usmerjena organizacija}

Da bi resnično razumeli značilnosti in pomen procesne usmerjenosti, najprej analizirajmo značilnosti funkcijske usmerjenosti in organiziranosti. To nam bo omogočilo razumeti ključne razlike med konceptoma funkcijske in procesne usmerjenosti organizacije.

\section{Funkcijska usmerjenost in organiziranost}

Za razumevanje temeljev današnje funkcijske usmerjenosti in organiziranosti moramo kar daleč v preteklost. Leta 1776 je Adam Smith v svoji znameniti knjigi Bogastvo narodov opisal svoje razumevanje družbenega razvoja in vodenja ekonomske politike. Za naše razumevanje je to delo pomembno zato, ker je Smith v njem na primeru izdelave šivank predstavil novo, za tiste čase revolucionarno, načelo delitve dela. Namesto dotedanjega načina dela, ko je vse potrebno opravil en sam mojster, je izdelavo razdelil na posamezne faze oziroma operacije, ki so jih opravljali različni delavci. Opisal je primer tovarne, v katerem je namesto mojstrov, ki bi v celoti opravili vseh $\mathrm{I} 8$ potrebnih operacij za izdelavo šivanke, delalo io delavcev, od katerih je vsak opravljal zgolj eno ali največ dve operaciji. Takšna delitev dela je po njegovem mnenju produktivnost povečala za več kot stokrat. Smith je prednosti videl predvsem v večji spretnosti delavcev pri izvajanju posameznih operacij, skrajševanju časa izdelave zaradi nepotrebnih zamud pri prehajanju z izdelave ene šivanke na izdelavo naslednje ter številnih možnostih izdelave pripomočkov in strojev, ki ne le olajšajo delo posameznika, ampak jih lahko tudi nadomeščajo (Smith 20I0). McCormack trdi, da je Smith s tem postavil organizacijski model 
poslovanja za skoraj naslednjih dvesto let. Koncept je doživel le dve evoluciji. Šele na prelomu v 20. stoletje so pri obnovi ameriških železnic in industrije Smithova načela nadgradili s konceptom hierarhične organizacije dela. V 20-ih letih prejšnjega stoletja pa sta Pier S. DuPont in Alfred Sloan koncept družinskih podjetij zamenjala s poslovnim modelom sodobnih korporacij in s tem poskrbela za drugo evolucijo Smithovih načel (McCormack 2007, 22).

Koncept funkcijske organiziranosti je zaradi svojih značilnosti organizacijam desetletja pomagal izboljševati organiziranost, uspešnost in učinkovitost dela. Svoje slabosti je začel kazati šele v 60-ih in 70-ih letih preteklega stoletja ob izjemnem dvigu kakovosti in konkurenčnosti japonske avtomobilske industrije ter njenem prodoru na ameriški trg.

Funkcijska ali vertikalna organiziranost je še vedno najbolj razširjen pristop oblikovanja organizacijskih struktur. Njene prednosti so predvsem $v$ tem, da znotraj funkcij spodbuja ekonomijo obsega in omogoča kritično maso poglobljenega znanja ter veščin. Takšna organizacijska struktura je primerna za organizacije z manjšim številom izdelkov. So pa takšne organizacijske strukture zelo toge, $\mathrm{z}$ veliko nivoji odločanja, kar zmanjšuje sposobnosti odzivanja na spremembe. Za funkcijsko organizacijsko strukturo je značilna slaba horizontalna koordinacija med funkcijami, kar zmanjšuje uspešnost in učinkovitost delovanja medfunkcijskih procesov (Spany 2007).

Za funkcijsko usmerjenost in organizacijsko strukturo je torej še najznačilnejše povezovanje ljudi s sorodnimi kompetencami v skupine za potrebe operativne učinkovitosti in poročanja (McCormack 2007). Skupine morajo biti dovolj velike, da zagotavljajo potrebno kritično maso za kakovostno, uspešno in učinkovito delo. Za zaposlene v funkcijski organizacijski strukturi je ključno vprašanje Komu poročam (komu sem odgovoren)? Kdo so tisti, ki zaposlenim določajo vloge, položaje, določajo naloge in cilje, ki nenazadnje odločajo o skupinski in individualni uspešnosti? Njim poročajo zaposleni, zato je najpomembnejše, da so v očeh slednjih uspešni in učinkoviti. Ta logika pa seveda v ospredje postavlja uresničevanje predvsem nalog in ciljev lastnega oddelka, organizacijske enote oziroma funkcije, včasih tudi na škodo drugih enot ali organizacije kot celote, še posebej takrat, ko se močna funkcijska organiziranost ujame z izrazito avtoritarnim stilom vodenja. Koncept funkcijske organiziranosti shematsko prikazuje slika 19 . 


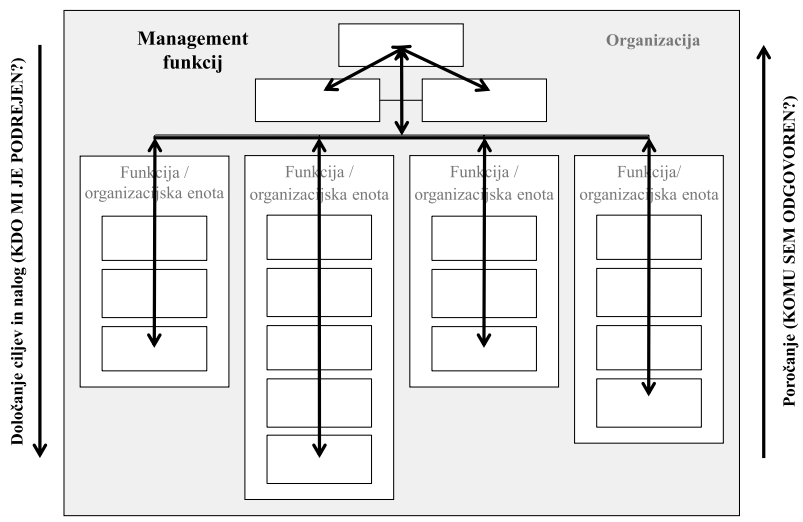

Slika 19: Funkcijska usmerjenost in organizacijska struktura

Galbraith na osnovi predhodnih študij drugih avtorjev podrobno analizira razlike med organizacijami, osredotočenimi na izdelke, in organizacijami, osredotočenimi na odjemalce (Galbraith 2005). Nekatere od razlik, izbrane za potrebe naše raziskave, prikazuje preglednica 6 .

Preglednica 6: Osredotočenost na izdelke in osredotočenost na odjemalca

\begin{tabular}{|c|c|c|c|}
\hline & Elementi & $\begin{array}{l}\text { Osredotočenost } \\
\text { na izdelke }\end{array}$ & $\begin{array}{l}\text { Osredotočenost } \\
\text { na odjemalce }\end{array}$ \\
\hline \multirow[t]{3}{*}{ Strategija } & Cilj & Najboljši izdelek za kupca & Najboljša rešitev za kupca \\
\hline & $\begin{array}{l}\text { Osnova za določanje pri- } \\
\text { oritet }\end{array}$ & Portfelj izdelkov & $\begin{array}{l}\text { Portfelj kupcev - profitabil- } \\
\text { nost kupcev }\end{array}$ \\
\hline & Cenovna politika & Glede na trg & $\begin{array}{l}\text { Glede na vrednost in tveg- } \\
\text { anja }\end{array}$ \\
\hline Struktura & Organizacijski koncept & $\begin{array}{l}\text { Izdelčni profitni centri, pre- } \\
\text { gledi izdelkov, izdelčni timi }\end{array}$ & $\begin{array}{l}\text { Segmentiranje odjemal- } \\
\text { cev, timi odjemalcev, prof- } \\
\text { itabilnost oz. izgube odje- } \\
\text { malcev }\end{array}$ \\
\hline Procesi & Najpomembnejši proces & Razvoj novih izdelkov & $\begin{array}{l}\text { Management odnosov z } \\
\text { odjemalci in razvoj rešitev }\end{array}$ \\
\hline \multirow[t]{2}{*}{ Ljudje } & Miselni proces & $\begin{array}{l}\text { Divergentno razmišljan- } \\
\text { je: koliko je možnih upor- } \\
\text { ab izdelka? }\end{array}$ & $\begin{array}{l}\text { Konvergentno razmišl- } \\
\text { janje: katera kombinaci- } \\
\text { ja izdelkov je za odjemalca } \\
\text { najboljša? }\end{array}$ \\
\hline & Kultura & $\begin{array}{l}\text { Kultura novih izdelkov: } \\
\text { odprtost za nove ideje, eks- } \\
\text { perimentiranje }\end{array}$ & $\begin{array}{l}\text { Kultura urejanja odnosov: } \\
\text { iskanje potreb odjemalcev, } \\
\text { ki jih je potrebno izpolniti }\end{array}$ \\
\hline
\end{tabular}

Vir: Galbraith 2005, I0. 
Chang (2006) meni, da je funkcijska organiziranost primerna za organizacije, katerih strategija temelji na stroškovni učinkovitosti, medtem ko je procesna usmerjenost primernejša za organizacije z različnimi izdel$\mathrm{ki}$ in storitvami. Razlike $\mathrm{v}$ značilnostih funkcijske in procesne organizacije prikazuje preglednica 7 .

Preglednica 7: Značilnosti funkcijske in procesne organizacije

\begin{tabular}{|c|c|c|}
\hline & Funkcijska organizacija & Procesna organizacija \\
\hline Delovna enota & Oddelek & Skupina \\
\hline Ključna osebnost & Funkcijski vodja & Skrbnik procesa \\
\hline Prednosti & $\begin{array}{l}\text { Funkcijska odličnost } \\
\text { Enostavnejše usklajevanje dela } \\
\text { (podobne veščine) } \\
\text { Jasna usmeritev, kako mora biti delo } \\
\text { izvedeno }\end{array}$ & $\begin{array}{l}\text { Odzivnost na zahteve trga } \\
\text { Izboljšano komuniciranje in sodelo- } \\
\text { vanje med različnimi funkcijskimi } \\
\text { nalogami } \\
\text { Merjenje uspešnosti je povezano s } \\
\text { cilji procesa }\end{array}$ \\
\hline Slabosti & $\begin{array}{l}\text { Komunikacijske ovire med funk- } \\
\text { cijami } \\
\text { Slaba predaja naslednjim funkcijam, } \\
\text { kar vpliva na storitev do odjemalca } \\
\text { Pomanjkanje celovitega pogleda za } \\
\text { optimiziranje rezultatov organizacije }\end{array}$ & $\begin{array}{l}\text { Podvajanje funkcijskih znanj } \\
\text { Neusklajenost delovanja funkcij med } \\
\text { procesi } \\
\text { Večja operativna kompleksnost }\end{array}$ \\
\hline Strateška vrednost & Podpira strategijo nizkih stroškov & Podpira strategijo diferenciacije \\
\hline
\end{tabular}

Vir: Chang 2006, 21.

\section{Procesna usmerjenost in delovanje organizacije ${ }^{t}$}

Procesna usmerjenost je sodobnejši koncept, ki za razliko od funkcijske usmerjenosti v ospredje postavlja odjemalce in izpolnjevanje njihovih zahtev ter pričakovanj. Namesto vprašanja »Komu poročam (komu sem odgovoren)? « pred vsakega zaposlenega postavlja vprašanje »Komu dodajam vrednost? « Odgovori na to vprašanje pa vertikalen pogled navzgor, $\mathrm{k}$ tistim, ki jim zaposleni poročajo, preusmerjajo $\mathrm{v}$ horizontalen pogled $\mathrm{k}$ tistim, za katere izdelujejo izdelke oziroma izvajajo storitve. Takšen pogled in posledično razumevanje pa pred zaposlene postavlja čisto drugačne izzive in cilje. Ne samo kakovost individualnega dela, pomembni postanejo predvsem kakovost in rezultati skupnega dela organizacije. V ospredju ni zadovoljstvo nadrejenih, ampak zadovoljstvo odjemalcev, posledično vodij in drugih deležnikov. Procesna usmerjenost torej zahteva korenite

I Odnosa med procesno usmerjenostjo in projektnim vodenjem ter matrično organiziranostjo ne obravnavamo ločeno v samostojnem podpoglavju, temveč v sklopu tega poglavja. 
spremembe $\mathrm{v}$ našem načinu razmišljanja in razumevanja, $\mathrm{v}$ naših odnosih in odločitvah. To horizontalno razumevanje poslanstva in delovanja organizacije prikazuje slika 20.

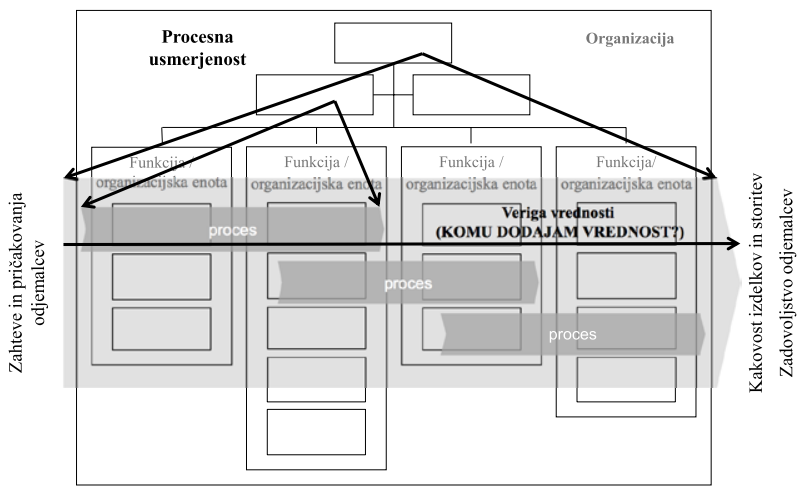

Slika 20: Procesno razumevanje delovanja organizacije

Za uspešen prehod iz funkcijskega v procesno razmišljanje in delovanje moramo v ospredje postaviti uspešnost procesov in organizacije kot celote; torej skupni interes postaviti pred parcialnega. Na tej osnovi se spremeni tudi nagrajevanje uspešnosti. Namesto prispevka posameznikov $\mathrm{k}$ uspehu organizacijske enote vodje $\mathrm{v}$ procesno usmerjenih organizacijah prepoznavajo, priznavajo in nagrajujejo prispevek posameznikov ter skupin k rezultatu celotne organizacije. Procesna usmerjenost torej prinaša radikalno drugačno razumevanje delovanja organizacij. Harrington razlike med značilnostmi funkcijske in procesne usmerjenosti prikaže, kot je predstavljeno v preglednici 8 (Harrington 1991, 5).

Preglednica 8: Značilnosti osredotočenosti na organizacijo oziroma na procese

\begin{tabular}{ll}
\multicolumn{1}{c}{ Osredotočenost na organizacijo } & \multicolumn{1}{c}{ Osredotočenost na procese } \\
\hline Problem so zaposleni & Problem je proces \\
\hline Zaposleni & Ljudje \\
\hline Delam svoje delo & Pomagam narediti stvari \\
\hline Razumem svoje delo & Razumem, kako se moje delo vključuje v celoten proces \\
\hline Merjenje posameznikov & Merjenje procesa \\
\hline Spremeniti osebo & Spremeniti proces \\
\hline Vedno lahko najdemo bolǰ̌ega zaposlenega & Vedno lahko izboljšamo proces \\
\hline Motiviranje zaposlenih & Odstranjevanje preprek \\
\hline
\end{tabular}




\begin{tabular}{ll} 
Nadzor zaposlenih & Razvoj ljudi \\
\hline Ne zaupaj nikomur & V tem smo vsi skupaj \\
\hline Kdo je naredil napako? & Kaj je omogočilo napako? \\
\hline Korekcija napak & Zmanjševanje variance \\
\hline Vodenje z vidika operative & Vodenje z vidika odjemalcev
\end{tabular}

Vir: Harrington 1991, 5.

De Toro in McCabe $(1997,55)$ opozarjata, da prehod iz tradicionalnega načina managementa $\mathrm{v}$ management poslovnih procesov zahteva radikalno spremembo miselnosti v organizaciji. Za tradicionalni način managementa je značilna vertikalna hierarhija odločanja, nadzora in kontrole ter osredotočenost na posameznika. BPM pa zahteva horizontalno, procesno usmerjeno in sploščeno strukturo, osredotočeno na skupine. To svoje razumevanje še bolj plastično predstavita s prispodobo, da so $\mathrm{v}$ tradicionalni organizaciji managerji misleci, ki postavljajo prioritete in odločajo, dajejo ukaze in navodila ter nadzorujejo in kontrolirajo izvajanje. Zaposleni so zgolj delavci, izvajalci. V procesni strukturi pa so misleci delavci in skrbniki procesov, skupine in posamezni izvajalci procesov, saj načrtujejo svoje delo, preverjajo rezultate in s ciljem izboljševanja spreminjajo način dela.

Cronemyr (2007, povz. po Cronemyr in Danielsson 2013, 934) poudarja razliko med organizacijsko in procesno shemo. Organizacijska shema sporoča, kaj organizacija labko dela, njen namen je doseganje notranjih ciljev. Za razliko od organizacijske procesna shema prikazuje, kaj organizacija dejansko dela, in je usmerjena bolj v zunanje cilje, npr. v doseganje zadovoljstva odjemalcev.

Škrinjar (2010, I86-87) analizira različne konceptualizacije procesne usmerjenosti (Davenport 1993; Hammer in Champy 1993; Byrne 1993; Stark in Black 1994; Sung in Gibson 1998; Ostroff 1999; McCormack in Johnson 200I; Balzarova idr. 2004; Kovačič in Boksilj-Vukšić 2005; Reijers 2006; Willaert idr. 2007; Galbraight 2005; Spanyi 2007; Daft 2007; Kohlbacher 2008; Neubauer 2009 in Bandara idr. 2009) in na tej osnovi razvije razširjen okvir procesne usmerjenosti, ki ga prikazuje slika 2I. $\mathrm{Z}$ uporabo faktorskih uteži Škrinjar preveri povezanost posameznih elementov $s$ procesno usmerjenostjo. Elementi v notranji elipsi so $s$ procesno usmerjenostjo povezani močneje. 


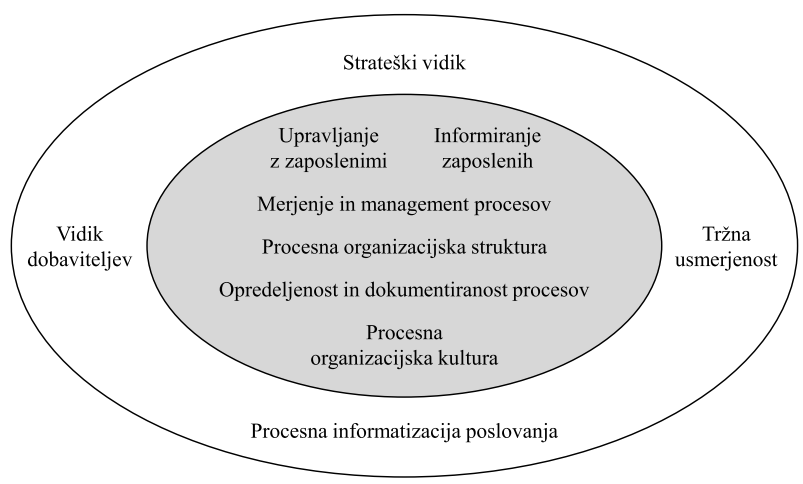

Slika 2 1: Razširjen okvir procesne usmerjenosti

Vir: Škrinjar 2010, 188.

Z obsežno študijo literature Van Looy $(2014,53)$ opredeli odnos med konceptoma procesne usmerjenosti in managementa poslovnih procesov. Analiza uveljavljenih definicij pojma proces kaže, da se te osredotočajo predvsem na modeliranje in udejanjanje procesov. Uveljavljene definicije BPM pa poudarjajo predvsem optimizacijo in management procesov, ki jih izvajajo skrbniki procesov in medfunkcijski procesni timi. Te procesne značilnosti literatura $\mathrm{v}$ kontekstu zrelostnih modelov imenuje področja zmogljivosti procesov oziroma BPM. Sodobnejša literatura pa vse bolj poudarja tudi pomen drugih organizacijskih značilnosti za doseganje odličnosti procesov, predvsem organizacijske strukture in organizacijske kulture. Da bi opredelili to razliko v obsegu konceptov, avtorji razvijejo koncept procesne usmerjenosti. McCormack $(2007,270)$ definira, da procesna usmerjenost namesto hierarhij poudarja procese, procesno usmerjen način razmišljanja, odjemalce in končne rezultate. V procesni organizacijski strukturi so uveljavljene procesne vloge, kot npr. skrbnik procesa in procesni timi. Procesno usmerjeno organizacijsko kulturo najvišje vodstvo udejanja $\mathrm{z}$ uveljavljanjem ustreznih vrednot, $\mathrm{z}$ lastnim zgledom ter nagrajevanjem, vezanim na uspešnost procesov namesto na rezultate organizacijskih enot. Odnos med konceptoma BPM in procesno usmerjenostjo (BPO) prikazuje slika 22.

Področja zmogljivosti procesov Van Looy (2014, 54-55) razume kot nabor kompetenc, vrednot in vedenja, ki jih organizacija potrebuje, da bi uresničevala načrtovane cilje procesov. Zato posamezna področja zmogljivosti deli na vsebinsko zaokrožene sklope značilnosti ali dele področij zmogljivosti. Zmogljivost modeliranja tako deli na zmogljivost načrtovanja in na zmogljivost analiziranja. Področje uvedbe deli na vzpostavitev in 
merjenje. Tudi zmogljivost optimiziranja deli na dve vsebinsko povezani celoti, in sicer ocenjevanje in izboljševanje. Znotraj zmogljivosti managementa prepoznava zmogljivosti, povezane $\mathrm{s}$ strategijo, z zunanjimi povezava$\mathrm{mi}$, vlogami, veščinami in vsakodnevnim managementom. Zmogljivosti razvijanja potrebne procesno naravnane kulture deli na vrednote, odnose in vedenje, ocenjevanje in vrhnji management. Zmogljivosti vzpostavitve ustrezne strukture deli na organizacijsko shemo in telesa upravljanja.

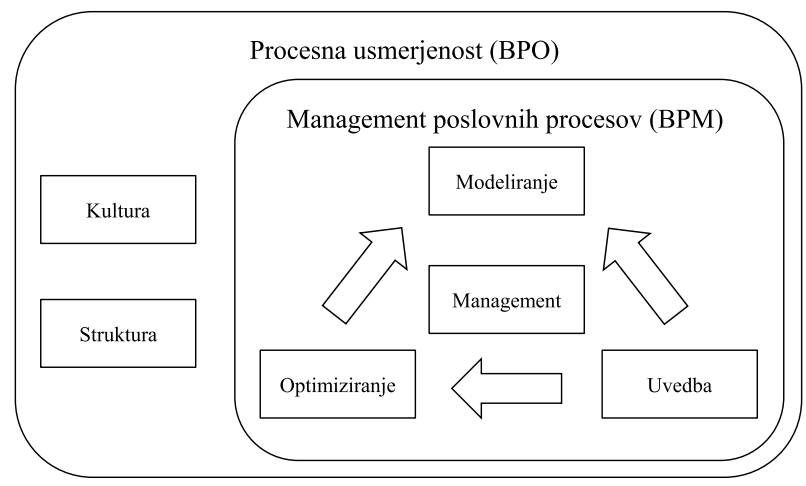

Slika 22: Področja zmogljivosti BPM in BPO

Vir: Van Looy 2014, 54.

\section{Razvoj organizacijskih struktur ${ }^{2}$}

Kljub pomanjkljivostim je funkcijska organizacijska struktura, o kateri podrobneje pišemo v razdelku 4.I, danes še vedno prevladujoča. Glede na koristi procesne usmerjenosti bi pričakovali, da se bodo v organizacijah, še posebej v majhnih in srednje velikih', hitreje uveljavljale horizontalne organizacijske strukture. A je ta proces kljub številnim vplivom in izzivom, ki jih prinašajo procesna usmerjenost, globalizacija in povezovanje, internet in številne nove tehnologije, zelo počasen, evolucijski.

$\mathrm{V}$ velikih, kompleksnih organizacijah se je organizacijska struktura na uveljavila osnovi tržne ali izdelčne segmentacije (Spany 2007). Manjše poslovne enote ${ }^{4}$ so organizirane glede na posamezne trge oziroma geograf-

2 V dispoziciji smo poglavje poimenovali Matrična organizacijska struktura. V nalogi širše predstavljamo razvoj organizacijskih struktur, ki je v veliki meri povezan z uveljavljanjem procesne usmerjenosti.

3 »Zakon o gospodarskih družbah«(ZGD-I, Uradni list $R S$, št. 42/2006 z dne 19. 4. 2006) v 55. členu gospodarske družbe z uporabo meril povprečnega števila delavcev v poslovnem letu, čistih prihodkov od prodaje in vrednosit aktive razvršča na mikro, majhne, srednje in velike družbe.

$4 \mathrm{~V}$ angleški literaturi pogosto uporabljana kratica SBU (angl. Small Business Unit). 
ska področja ali skupine izdelkov. Takšna organiziranost se je uveljavila predvsem $\mathrm{v}$ storitvenih dejavnostih, npr. bančnih, zavarovalniških in telekomunikacijskih ter $\mathrm{v}$ izdelčno-storitvenih dejavnostih, npr. v farmacevtski dejavnosti. Takšna organizacijska struktura omogoča večjo osredotočenost organizacij na specifične zahteve in pričakovanja ciljnih skupin določenih izdelkov, trgov ali regij, s tem pa tudi boljšo odzivnost na spremembe. Po drugi strani tržna ali izdelčno usmerjena organiziranost prinaša podvajanje virov ter zmanjševanje ekonomije obsega znotraj posameznih poslovnih enot. Za takšno organiziranost sta značilni tudi slaba koordinacija in standardizacija postopkov med enotami. To se kot največja slabost pokaže pri odjemalcih, ki se srečujejo z različnimi ljudmi $s$ področja prodaje, tehnične ali poprodajne podpore iz različnih poslovnih enot iste organizacije.

Zaradi navedenih slabosti sledita razvoj in uveljavljanje hibridne organizacijske strukture, osredotočene na odjemalce. Galbraith (2005) uveljavi pojem na odjemalce osredotočene organizacijes. Uveljavljanje moči in vpliva odjemalcev na poslovanje je management vodilo k spoznanju o strateškem pomenu odjemalcev za povečevanje konkurenčnosti, finančno uspešnost in dolgoročni razvoj. Ključne razloge za povečanje vpliva odjemalcev Galbraith (2005, I I) vidi v globalizaciji odjemalcev, večji naklonjenosti odjemalcev trajnejšim odnosom in razvijanju partnerstev, pojavu e-poslovanja in vse izrazitejših zahtevah odjemalcev po celovitih rešitvah. Takšnim izzivom pa klasična organiziranost po izdelkih, področjih ali funkcijah ne zadošča več. Zato Galbraith obstoječim poslovnim enotam s ciljem uveljavljanja naravnanosti na odjemalce doda skupno enoto, preko katere poslovne enote $\mathrm{v}$ začetnih in zaključnih aktivnostih koordinirano komunicirajo $\mathrm{z}$ odjemalci. To skupno enoto poimenuje začetno-končna ${ }^{6}$ enota. Ker je tako veliko vprašanj, glede katerih imajo poslovne enote v ozadju in enota v ospredju različna mnenja, je management procesov še toliko pomembnejši (Galbraith 2005, I65). Med najpomembnejšimi procesi avtor izpostavi strateško usklajevanje razvoja izdelkov z načrti odjemalcev, management portfelja izdelkov in management priložnosti.

Galbraith opozarja, da organizacija ni samo njena struktura. Ključne elemente organizacije, strategijo, ljudi, strukturo, procese in nagrajevanje ter njihove medsebojne povezave, predstavi z modelom zvezda, ki ga prikazuje slika 23 (Galbraith 2005, I5-24). Naloga strategije je, da zagotovi jasno usmeritev, določa stopnje in obseg ter zagotavlja integracijo. Značilnosti strategije na odjemalce osredotočene organizacije so iskanje

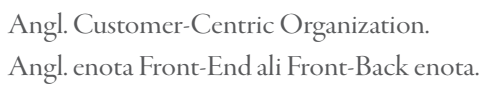


najboljših rešitev za odjemalce, ki so prilagojene njihovim potrebam, portfelj odjemalcev glede na njihovo dobičkonosnost in zvestobo ter pošteno razmerje med ceno in vrednostjo. Za procesno naravnane organizacije je značilno oblikovanje enot glede na ciljne skupine odjemalcev, ključne vloge prevzemajo managerji ključnih strank in projektni managerji, posebna pozornost je namenjena razvoju veščin timskega dela in reševanja konfliktov. $\mathrm{V}$ ospredju so procesi, naravnani k odjemalcem, npr. management odnosov z odjemalci (CRM) in razvoj storitev. Sistem nagrajevanja priznava in spodbuja rezultate, povezane z odjemalci, in skupne rezultate organizacije. Za trajnostno uspešnost je ključnega pomena, da so spodnji štirje elementi na sliki 23 skladni s strategijo in da so vsi elementi med seboj močno povezani.

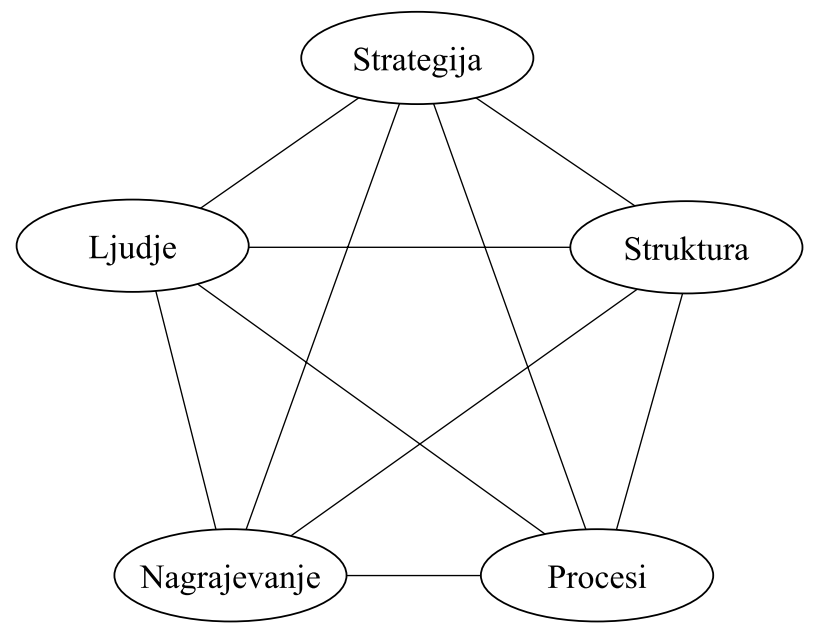

Slika 23: Zvezda model organizacije

Vir: Galbraith 2005, 15 .

Organizacije z nekaj izdelki in lokalnimi odjemalci lahko delujejo skozi funkcionalno hierarhijo. Velike, multinacionalne korporacije z več izdelčnimi linijami in funkcijskimi enotami v različnih državah pa morajo razvijati zmogljivosti lateralnega mreženja med enotami in linijami. Galbraith prepoznava 6 faz prehoda $\mathrm{z}$ izdelčno naravnane v procesno naravnano organizacijo (Galbraith 2005, 36). V prvi fazi je povezovanje prostovoljno in neformalno. $\mathrm{V}$ drugi fazi se uveljavi e-koordinacija. Za tretjo fazo so že značilne tako enostavne kot večdimenzionalne formalne skupine na različnih ravneh organiziranosti. Četrta faza že vključuje formalnega koordinatorja, ki je bodisi v obliki vloge oziroma delovnih nalog bodisi 
kot organizacijska enota. Šesto fazo predstavlja matrična organiziranost. $\mathrm{V}$ matrični organiziranosti je dimenzija odjemalcev in osredotočenosti nanje strateško enako pomembna, kot so države ali poslovne enote. $V$ tej obliki organiziranosti postajajo organizacije odjemalcev partnerji, ki se vključujejo v procese odločanja. V zadnji fazi se oblikujejo v odjemalce usmerjene organizacijske enote, linije, v katerih so zbrani vsi s specifičnimi odjemalci povezani zaposleni. $V$ avtomobilski dobaviteljski verigi se za takšne z odjemalci povezane enote uveljavi kratica $\mathrm{CBU}^{7}$.

Spany (2007) kot prednost matrične strukture prepoznava predvsem sposobnost prožnejše uporabe človeških virov med izdelčno ali geografsko organiziranimi poslovnimi funkcijami, saj to omogoča razvijanje tako funkcijskih kot izdelčnih veščin. Med slabostmi opozarja predvsem na dvojno, vertikalno in horizontalno, vodenje, ki pri zaposlenih lahko povzroča nelagodje in frustracije. Številni sestanki vodijo v izgubo časa, za ohranjanje jasnosti usmeritev in prioritet je potrebno veliko napora. Matrična organiziranost zahteva razvijanje veščin medčloveških odnosov.

Matrična organiziranost se je močno uveljavila tudi v povezavi s projektnim vodenjem. $Z$ vidika naše raziskave je projektno vodenje pomembno zato, ker so projekti v bistvu enkratna izvedba procesa. Uporabimo primer. Uspešne organizacije skozi proces razvoja nenehno razvijajo svoje izdelke in storitve. $\mathrm{V}$ primeru enostavnih izdelkov razvoj poteka v okviru razvojnih nalog. Kadar pa so izdelki in storitve zelo kompleksni, kadar razvoj zahteva veliko virov ali pa so roki dokončanja kratki, je cilje mogoče uspešno in učinkovito uresničiti le $\mathrm{z}$ uporabo metodologije projektnega vodenja. Vodnik po znanju projektnega vodenja $(\mathrm{PMBOK})^{8}$ projekt definira kot začasno prizadevanje za uresničitev edinstvenega izdelka, storitve ali rezultata (PMI 2008, 374). Projekti se izvajajo zato, da zagotovijo vrednost za odjemalce. So nepogrešljiv sestavni del načrtovanja in uresničevanja strategije organizacije (Athayde idr. 2007). Projektno vodenje je področje procesov, ki poteka skozi procese zagona, planiranja, izvajanja, spremljanja in kontroliranja ter dokončanja projekta. Metodologija vodenja projektov pa z uporabo znanja, veščin, tehnik in orodij omogoča uspešno izvajanje procesov projektnega vodenja in uresničevanje ciljev projekta (PMI 2008, 8). Za vodenje projekta in uresničitev njegovih ciljev je odgovoren vodja projekta.

Uspešno projektno vodenje je mogoče le $\mathrm{v}$ procesno in projektno usmerjenih organizacijah $\mathrm{z}$ razvito kulturo timskega dela in sodelovanja 
ter primerno organizacijsko strukturo, ki uveljavlja vlogo vodje in sponzorja projekta. Vpliv organizacijske strukture na projektno vodenje, ki ga na osnovi izkušenj iz prakse prikazuje Vodnik po znanju projektnega vodenja (PMI 2008, 28), lahko smiselno uporabimo tudi z vidika vloge in pooblastil skrbnika procesa (slika 24).

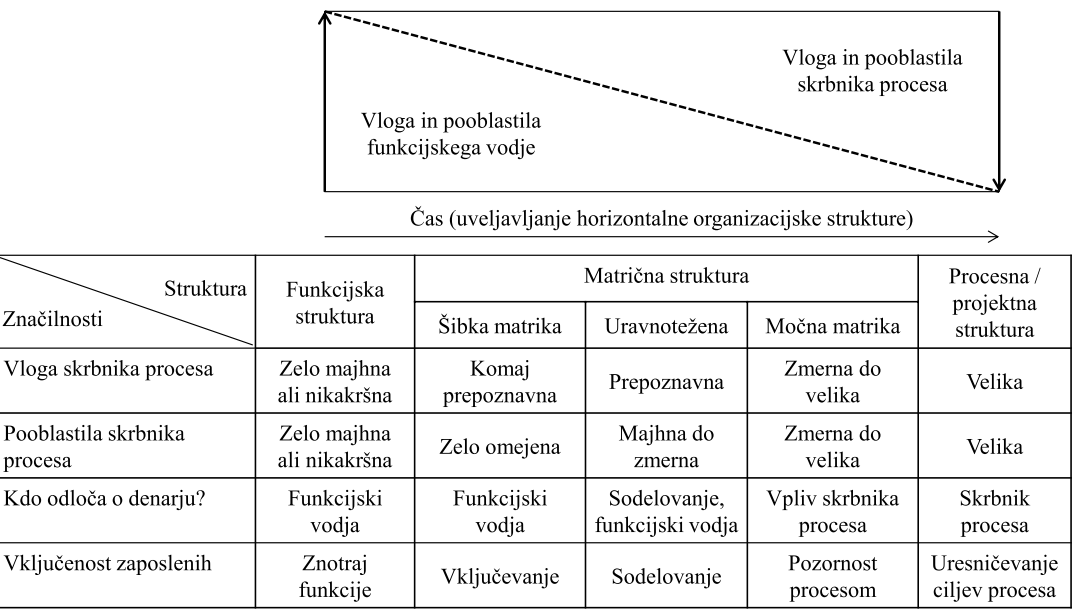

Slika 24: Uveljavljanje horizontalne organizacijske strukture

Vir: Prirejeno po PMI 2008, 28.

Pogost vzrok za konflikte v matrični strukturi je nerazumevanje vlog funkcijskih, vertikalnih in projektnih oziroma procesnih, torej horizontalnih vodij. Projektni vodje so odgovorni za rezultate projekta, zato morajo s projektno skupino zagotoviti prave odgovore na naslednja vprašanja:

- $\quad k a j$ je treba narediti (zahteve),

- do kdaj je treba narediti (rok) in

- sčim je treba narediti (razpoložljivi finančni viri).

Funkcijski vodje pa razpolagajo z ljudmi in infrastrukturo. Zatorej so le oni s sodelavci sposobni ustrezno odgovoriti na vprašanji:

- $\quad k d o$ bo izvedel aktivnosti projekta znotraj posamezne funkcije (dodeljevanje zaposlenih na projekte) in

- kako, na kakšen način jih bo izvedel (pristopi in tehnologija).

Kadar koli bodisi horizontalni bodisi vertikalni vodje s svojimi odločitvami posegajo $\mathrm{v}$ vsebino in pooblastila drugih vodij, odpirajo polje 
nerazumevanja in konfliktov. Zato so za uspešno uveljavljanje procesne usmerjenosti in projektnega vodenja tako zelo pomembni usposabljanje, znanje in razumevanje.

\section{Razvijanje procesne usmerjenosti}

Škrinjar (2010, I9I-92) razvijanje in uveljavljanje procesne usmerjenosti vidi v štirih korakih. Temeljni korak je zavedanje vodstva o pomenu procesne usmerjenosti in njenem vplivu na uspešnost poslovanja. Ker je vrhnje vodstvo organizacij, še posebej v zadnjih letih globalne krize, tako izrazito osredotočeno predvsem na finančne rezultate, so tako pomembne raziskave, ki se osredotočajo na vpliv procesne usmerjenosti tako na nefinančne kot na finančne rezultate. Procesna usmerjenost ni recept za hitro izboljšanje rezultatov, temveč sistematičen pristop k razvijanju zmogljivosti procesov za dolgoročno uspešnost organizacije. Druga faza je razumevanje širšega koncepta in elementov procesne usmerjenosti. Razumevanje vseh elementov in dejavnikov, ki so ključni za uspešno uveljavljanje procesne usmerjenosti, mora vodstvo sistematično širiti na nižje ravni, do vseh zaposlenih. Tretja faza je ocenjevanje in načrtovanje. Vodstvo organizacije $\mathrm{z}$ izbiro primernega instrumenta za merjenje procesne usmerjenosti in/ali primernega zrelostnega modela za ocenjevanje ugotovi obstoječe stanje in določi cilje izboljšav. Zadnja faza je udejanjanje izboljšav in prehod na višjo stopnjo zrelosti. V tej fazi vodstvo točke preloma uporabi kot smernice za izboljševanje in osnovo za določanje prioritet.

Merjenje procesne usmerjenosti in/ali ocenjevanje zrelosti s pomočjo zrelostnih modelov organizacijam omogoča razumeti, kje so na poti uveljavljanja procesne usmerjenosti. Toda vedeti, kje si, še ne pomeni tudi imeti odgovore na vprašanja, kako naprej. Katere prakse vpeljati, uveljaviti ali izboljšati za uspešen prehod na višjo raven zrelosti in ta to, da se na višji ravni tudi obstane, torej zagotovi trajnostno delovanje? Škrinjar poudarja, da je sicer pomembno uveljavljati vse elemente in prakse procesne usmerjenosti, da pa so za uveljavitev in prehajanje na višje stopnje zrelosti nekatere prakse vendarle ključne (Škrinjar 2010, I82). Na podlagi širšega koncepta procesne usmerjenosti, ki smo ga predstavili v poglavju 4.2, Škrinjar razvije razširjen zrelostni model in $\mathrm{z}$ analizo z uporabo metode dreves odločanja prepozna te ključne prakse na posameznih stopnjah ter jih poimenuje točke preloma. Brez teh praks organizacija ne more uspešno ohranjati dosežene ravni. 
Prehodi zrelostnih stopenj $\quad$ Točke preloma po elementih procesne usmerjenosti

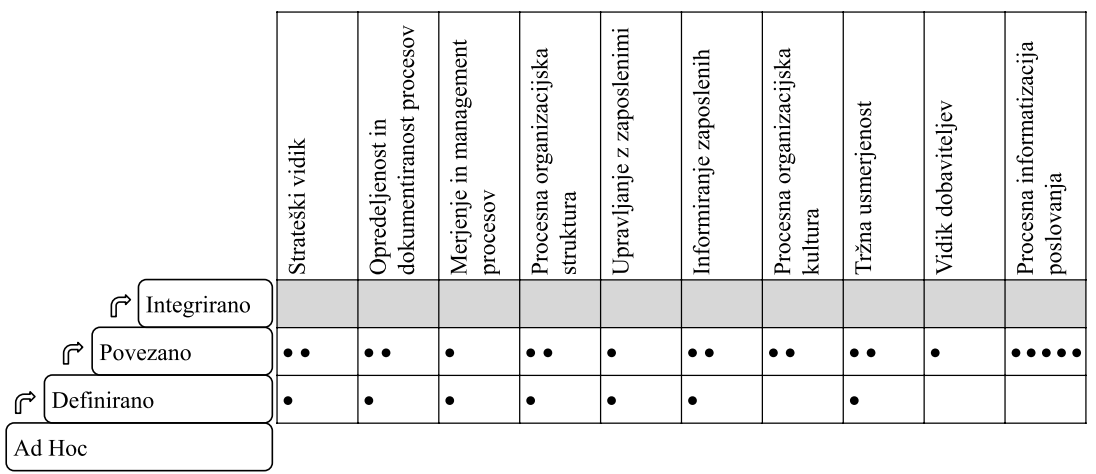

\section{Slika 25: Točke preloma pri uveljavljanju in razvijanju procesne usmerjenosti Vir: Prirejeno po Škrinjar 20 I0, 182-83.}

$S$ slike 25 lahko vidimo, da je za prehod na drugo stopnjo, Definirano, in trajnostno uveljavitev ključnih praks potrebnih 7 točk preloma. Prehod na višjo stopnjo, Povezano, je še težavnejši. V tem prehodu je še posebej pomembna vloga procesne informatizacije poslovanja. Informacijski sistemi na tej stopnji vodjem zagotavljajo relevantne informacije o učinkovitosti procesov, organizacije uporabljajo sodobne sisteme za management procesov in orodja za CRM, elektronsko so povezane s poslovnimi partnerji. Na tej stopnji se že uveljavlja procesna organizacijska kultura, kar pomeni, da povprečni zaposleni delovanje organizacije razumejo kot medsebojno povezane procese. Zato je vse pomembnejše celovito informiranje zaposlenih o strateških usmeritvah in ciljih ter kazalnikih uspešnosti procesov. Uveljavlja se tudi procesna organizacijska struktura, v kateri je nedvoumno vzpostavljeno skrbništvo procesov. Poznavanje točk preloma organizacijam nudi smernice za izboljševanje, lahko pa služi tudi za postavljanje ciljev pri uveljavljanju procesne usmerjenosti in prehajanju na višjo stopnjo zrelosti. Avtorju točk preloma za prehod na najzahtevnejšo stopnjo, Integrirano, zaradi premajhnega vzorca organizacij na tej stopnji ni uspelo dokazati.

\section{Vpliv procesne usmerjenosti na uspešnost poslovanja}

Številni avtorji poudarjajo, da imata procesni pogled na poslovanje in procesna usmerjenost pozitiven vpliv na poslovno uspešnost (Davenport 1993; Hammer in Champy 1993; McCormack in Johnson 2001; Burlton 200I; Harmon 2007). Tudi McCormack (2007) povzema prve raziskave 
in trditve, da razvijanje procesne usmerjenosti organizacije vodi do pozitivnih notranjih in zunanjih rezultatov.

Škrinjar (2010, I85) ugotavlja, da je bilo v preteklosti nekaj empiričnih raziskav, ki so z različnih vidikov preučevale vpliv procesne usmerjenosti na uspešnost poslovanja. Vendar je njihova skupna pomanjkljivost sama definicija uspešnosti poslovanja. Sam pri preučevanju vpliva procesne usmerjenosti na uspešnost poslovanja le-to definira širše in ob finančnih rezultatih upošteva tudi zadovoljstvo odjemalcev, dobaviteljev in zaposlenih. S svojo analizo Škrinjar ne more potrditi hipoteze, da večja procesna usmerjenost vodi k večji finančni uspešnosti. Ugotavlja pa, da imajo organizacije, ki so bolj procesno usmerjene, zadovoljnejše zaposlene, odjemalce in dobavitelje, da so torej nefinančno uspešnejše. Nefinančna uspešnost pa prispeva $\mathrm{k}$ večji finančni uspešnosti organizacij. Večja procesna usmerjenost torej posredno, preko nefinančne uspešnosti, prispeva tudi k finančni uspešnosti organizacij.

Ugotovitve Gartnerjeve raziskave, ki je vključevala 20 organizacij, kažejo, da naj bi $80 \%$ organizacij, ki izvajajo BPM-projekte, donosnost naložb povečalo za is \% (Hove, von Rosing in Storms 2015, 610). Velika večina teh organizacij ocenjuje, da so projekte zaključili z 9o-odstotno uspešnostjo. Vsi uspešno zaključeni projekti imajo donos naložb večji od ı $\%, \operatorname{kar} 78 \%$ projektov pa večji od Is \%. Organizacije, ki imajo vpeljano upravljanje procesov in BPM-center odličnosti, lahko dosegajo kar 5 -krat večji donos naložb od organizacij, ki nimajo ne centra odličnosti ne ustreznega procesnega tima (Palmer 2007, cit. po Hove, von Rosing in Storms 2015, 6ro). Podobno imajo organizacije z vzpostavljenimi procesnimi timi do 2-krat večjo donosnost naložb od organizacij brez procesnih timov (LEADing Practice Governance Reference Content, cit. po Hove, von Rosing in Storms 2015, 610).

\section{Povzetek pregleda literature}

Zaradi dolgoletne tradicije in vzgoje je v organizacijah še vedno prevladujoča funkcijska, vertikalna miselnost in organizacijska struktura. Procesno razumevanje organizacije je ob globalizaciji, internetu in številnih novih tehnologijah v veliki meri spodbudilo iskanje sodobnejših oblik organiziranja, od tržne in izdelčne segmentacije ter majhnih poslovnih enot, matrične organiziranosti, hibridne organizacijske strukture do mrežnega povezovanja in $\mathrm{v}$ odjemalce usmerjenih organizacijskih enot, kot so CBU-enote v avtomobilski industriji. Ključna dejavnika uspešne- 
ga razvijanja in udejanjanja procesne usmerjenosti sta zavedanje vodstva o pomenu procesne usmerjenosti in njenem vplivu na uspešnost poslovanja ter celostni, strateški pristop k BPM. Primerna načina razvijanja procesne usmerjenosti sta merjenje s pomočjo vprašalnikov ali ocenjevanje $s$ pomočjo zrelostnih modelov. Razumevanje točk preloma vodstvu organizacije omogoča trajno uveljaviti ključne prakse procesnega delovanja na doseženi zrelostni stopnji. Številni avtorji poudarjajo pomen procesne usmerjenosti za poslovno uspešnost organizacij. Prav vprašanje vpliva procesne usmerjenosti na poslovno uspešnost vse bolj izziva raziskovalce. Vendar na podlagi naših ugotovitev pregleda obstoječe literature na tem področju še ni celovitih raziskav, ki bi nedvoumno potrjevale pozitiven vpliv procesne usmerjenosti na uspešnost poslovanja. 


\section{Zrelostni modeli procesne usmerjenosti}

Že v razdelku 2.I smo predstavili popularnost in razširjenost uporabe procesov in managementa procesov $\mathrm{v} 90-\mathrm{ih}$ letih. Vendar so bili pristopi $\mathrm{k}$ implementaciji teh konceptov, pa tudi njihovi rezultati in koristnost, zelo različni. Zato so se tako v akademskih in raziskovalnih krogih kot tudi v praksi vse bolj zastavljala vprašanja o tem, kje je posamezna organizacija na poti uveljavljanja procesnega delovanja in BPM ter kako se na tej poti izboljševati in napredovati. Ti izzivi so spodbudili razvoj zrelostnih modelov procesne usmerjenosti.

Na področju TQM, ki je spodbudilo uveljavljanje procesov in BPM, je prvi model zrelosti, poimenoval ga je preglednica za ocenjevanje stanja kakovosti, predstavil Crosby (1990, 34-35). Stanje kakovosti je analiziral skozi šest kategorij kakovosti: razumevanje in odnos vodilnih delavcev, organiziranost službe za kakovost, reševanje problemov, stroške kakovosti, ukrepe za izboljšanje kakovosti ter skupno oceno stanja kakovosti v podjetju. Razvoj kakovosti Crosby prepoznava v petih stopnjah, to so: Negotovost, Prebujanje, Razsvetljenje, Modrost in Prepričanje. Crosby opozarja, da je od začetne stopnje, na kateri v organizacijah ne vedo, zakaj imajo probleme $s$ kakovostjo, pa do najvišje stopnje, ko v organizacijah vedo, zakaj nimajo problemov s kakovostjo, dolga in zahtevna pot.

Številni avtorji (Harmon 2003; Cronemyr in Danielsson 2013; Van Looy 20r4) prepoznavajo, da razvoj procesnih zrelostnih modelov sloni na zrelostnem modelu zmogljivosti procesa razvoja programske opreme $\mathrm{CMM}^{1}$, ki so ga leta 1993 predstavili na Software Engineering Institute

I CMM je registrirana blagovna znamka Software Engineering Institute Univerze Carnegie Mellon. 
Univerze Carnegie Mellon. Avtorji so v tehničnem poročilu predstavili uporabo zrelosti kot merila za ocenjevanje zmogljivosti procesov razvoja programske opreme, pri čemer zmogljivost procesov izdelave SW omogoča osnovo za napovedovanje verjetnih rezultatov prihodnjih SW-projektov organizacije. Zrelost nakazuje potencial za rast zmogljivosti in kaže na bogastvo procesov izdelave SW in doslednost, s katero se ti izvajajo skozi celotno organizacijo (Paulk idr. 1993, 3-4). Pet stopenj zrelosti CMM-modela predstavlja okvir petih zaporednih korakov nenehnega izboljševanja SW-procesov. Za prvo, začetno, stopnjo je značilno, da so procesi ad $h o c$, včasih tudi kaotični. Le malo procesov je definiranih, uspeh je odvisen predvsem od individualnih prizadevanj. Za drugo stopnjo, Ponovlji$v o$, velja, da vzpostavljeni osnovni procesi razvojnega projekta omogočajo spremljanje stroškov, rokov in funkcionalnosti. Vzpostavljena je osnovna disciplina, ki omogoča ponovljivost dobrih praks in uporabo dobrih praks predhodnih projektov za podobne aplikacije. Na tretji stopnji, Definirano, velja, da so tehnični in managerski procesi dokumentirani, standardizirani in integrirani v enoten proces izdelave SW. Juran (1988, povz. po Paulk idr. 1993, 17) je management kakovosti razdelil v 3 osnovne procese: planiranje kakovosti, kontrolo kakovosti in izboljševanje kakovosti. Vsak projekt na tretji stopnji uporablja odobreno in prilagojeno različico standardnega procesa za razvoj in vzdrževanje SW. Za četrto raven, Managerirano, je značilno, da so na razpolago podrobni rezultati meritev procesa in kakovosti SW. Tako proces kot izdelki so torej kvantitativno določeni in nadzorovani. Na najvišji stopnji, Optimizirano, se procesi na osnovi kvantitativnih povratnih informacij iz procesa ter pilotnih inovativnih idej in tehnologij nenehno izboljšujejo. Pričakovati je, da imajo organizacije, ki dosežejo to najvišjo stopnjo, zmogljive procese, ki zagotavljajo izdelavo visoko zanesljive programske opreme ob predvidljivih stroških in znotraj postavljenih rokov (Paulk idr. 1993, 8-9). CMM omogoča ocenjevanje procesa izdelave in ovrednotenje samega $S W$.

$\mathrm{Na}$ osnovi CMM-modela za razvoj programske opreme so bili kasneje razviti številni ločeni modeli za posamezna področja, npr. za sistemski inženiring, za nakup programske opreme, za sistemsko varnost in za človeške vire. S CMMI-modelom leta 2000 so vse te izpeljanke CMM-modela nadomestili s splošnim zrelostnim modelom, ki so ga kasneje z dopolnitvami v letih 2002, 2006, 2007 in 2009 razširili in naredili splošno uporabnega tudi za druge izdelke ter storitve v različnih panogah. Po mnenju avtorice je CMMI najbolj poznan splošen zrelostni model za poslovne procese (Van Looy 2014, 13). 


\section{Koncept procesne zrelosti}

Koncept procesne zrelosti izhaja iz razumevanja, da imajo procesi svoj življenjski cikel oziroma razvojne stopnje, ki jih je skozi čas mogoče jasno opredeliti, managirati, meriti in obvladovati. Višja stopnja zrelosti katerega koli procesa se odraža v izboljšanem napovedovanju ciljev, stroškov in poslovne uspešnosti, v večji uspešnosti doseganja ciljev ter v izboljšani zmogljivosti predlaganja novih, višjih ciljnih vrednosti poslovne uspešnosti (McCormack idr. 2009, 793).

Zrelostni modeli običajno predstavljajo logično pot iz obstoječega stanja v novo, želeno stanje zrelosti. Zato na tej poti vsebujejo zaporedje stopenj, tudi ravni ali faz (Becker idr. 2009; Gottschalk 2009, povz. po Röglinger, Pöppelbuß in Becker 20 I2, 329). Uporabljajo se za ocenjevanje trenutnega stanja, za usmerjanje izboljšav in za nadzor napredka. Na področju procesne usmerjenosti sta prepoznani dve vrsti modelov zrelosti: modeli, ki se osredotočajo na stanje oziroma zrelost posameznega procesa, in modeli, ki se osredotočajo na zrelost managementa poslovnih procesov (Rosemann in vom Brocke 2010; Smith in Fingar 2003).

Harrington (1991, 205) poudarja pomen kvalifikacije oziroma potrjevanja sposobnosti procesa $\mathrm{v}$ prizadevanjih za nenehno izboljševanje in inoviranje. Slab proces lahko hitro uniči leta trdih prizadevanj, saj si odjemalci razočaranje zapomnijo še dolgo potem, ko zbledi zadovoljstvo $s$ kakovostnim procesom. V 6-stopenjski lestvici modela so vsi še neocenjeni procesi uvrščeni v najnižjo, 6. stopnjo, Nepoznan. V 5. stopnjo, $R a$ zumljen, so uvrščeni procesi, ki jih izvajalci razumejo in izvajajo v skladu s predpisano dokumentacijo. V četrto stopnjo, Uspešen, sodijo procesi, ki so sistematično merjeni, v katerih so že stekli postopki izboljševanja in ki izpolnjujejo zahteve končnih odjemalcev. V 3. stopnji, Učinkovit, so že racionalizirani in učinkovitejši procesi. V 2. stopnjo, Brez napak, so uvrščeni visoko učinkoviti procesi brez napak. Najvišja, I. stopnja, Svetouni razred, je rezervirana za visoko prilagodljive, v svetovnem merilu najboljše procese, ki se nenehno izboljšujejo.

Podobno kot drugi zrelostni modeli je različna stanja procesov opredelil Wheeler (Wheeler 1997, povz. po Cronemyr in Danielsson 2013, 936). Avtor procese analizira $\mathrm{z}$ dveh vidikov, $\mathrm{z}$ vidika statistične kontrole (dimenzija procesa) in z vidika izpolnjevanja zahtev odjemalcev (vidik izdelka in storitve). V prvo stopnjo, ki jo poimenuje Stanje kaosa, uvrsti procese, ki statistično niso obvladovani in ne izpolnjujejo zahtev odjemalcev. Veliko je nenavadnih vzrokov variabilnosti, procesi se stalno spreminjajo in jih je težko izboljševati. Drugo stanje je poimenoval Rob kaosa. Procesi v tem stanju sicer niso obvladovani, a zahvaljujoč občutnemu dodatnemu 
delu izpolnjujejo zahteve odjemalcev. V tretjem stanju, ki ga imenuje $\mathrm{Na}$ pragu, se organizacije osredotočijo na procese, odstranijo vse nenavadne vzroke in zagotovijo obvladovane procese, ki pa ne izpolnjujejo zahtev odjemalcev. Zadnje stanje, v katerem obvladovani procesi izpolnjujejo zahteve odjemalcev, Wheeler poimenuje Idealno stanje.

Kot smo že zapisali v poglavju o izboljševanju procesov, tudi DeToro in McCabe $(1997,59)$ ocenjevanje stanja procesa predlagata kot primerno osnovo za izbiro prave poti izboljševanja.

Notranja ocena

Proces je brez napak, stroški na enoto so nizki, ni izgub, nizki stroški slabe

5

kakovosti

Proces je učinkovit, stroški so nizki,

4 izgube majhne, čas cikla je bil skrajšan

Proces se izvaja precej učinkovito, a ima priložnosti za izboljšave glede

3 trajanja cikla in stroškov na enoto

Proces je neučinkovit in potrebuje

2 izboljšave

Proces ima velike težave zaradi okvar, izgub, dolgih ciklov, visokih stroškov na enoto, zaposlenih in postopkov ter

1 stroškov slabe kakovosti
Učinkovitost

Stanje procesa

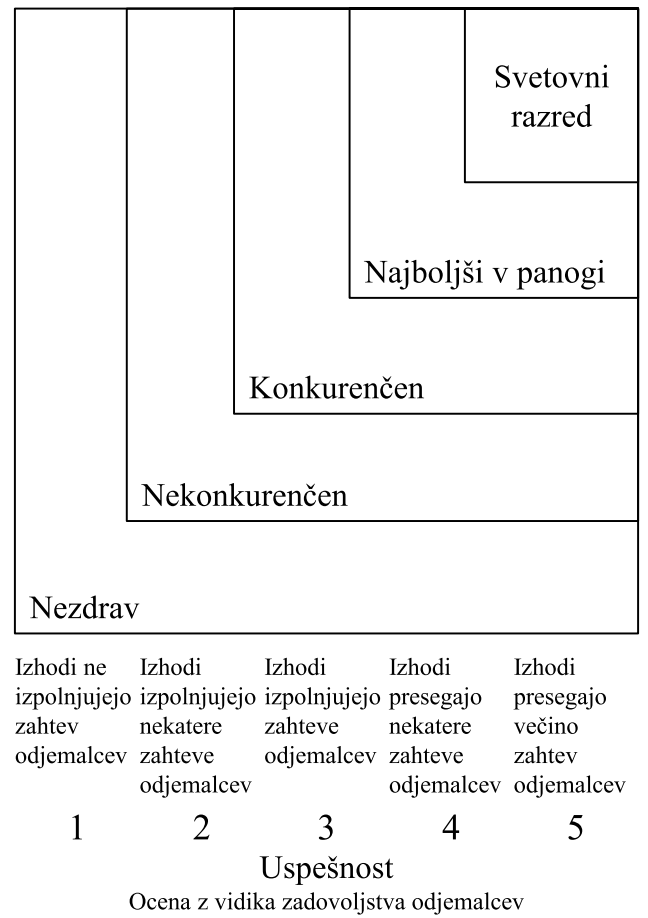

Slika 26: Ocenjevanje stanja procesa Vir: DeToro in McCabe 1997, 59.

Avtorja stanje procesa ocenjujeta $\mathrm{z}$ vidika uspešnosti (kako dobro proces izpolnjuje zahteve odjemalcev) ter $\mathrm{z}$ vidika učinkovitosti (kako dobro proces izpolnjuje notranje zahteve). Razvila sta 5 -stopenjski model, ki stanje procesa razvršča od najnižjega stanja, nezdrav, do najvišje stopnje, Svetouni razred (slika 26). 
Zrelost je torej merilo za ocenjevanje področij zmogljivosti, povezanih $s$ procesi, $\mathrm{z}$ managementom procesov ali s procesno usmerjenostjo. Tudi Hammer $(2007,3)$ zrelost razume kot zmogljivost procesov, da sčasoma zagotavljajo boljše rezultate. Zato si morajo organizacije prizadevati, da postanejo njihovi procesi zrelejši. To zahteva razvijanje dveh vrst značilnosti, na ravni posameznega procesa in na ravni organizacije kot celote. Značilnosti na ravni procesa Hammer poimenuje dejavniki, medtem ko značilnosti na ravni organizacije imenuje zmogljivosti. Dejavniki na ravni procesa so načrtovanje, izvajalci, skrbnik, infrastruktura in kazalni$k i$. Na ravni organizacije Hammer prepoznava naslednje zmogljivosti: voditeljstvo, kultura, strokovno znanje in upravljanje.

Poznavanje končnega cilja in razumevanje trenutnega položaja McCormack (2007, 6I-63) prepoznava kot kritični dejavnik uspeha na poti uveljavljanja procesne usmerjenosti. $\mathrm{V}$ pomoč ponudi instrument za merjenje procesne usmerjenosti in 4 -stopenjski model zrelosti (slika 27).

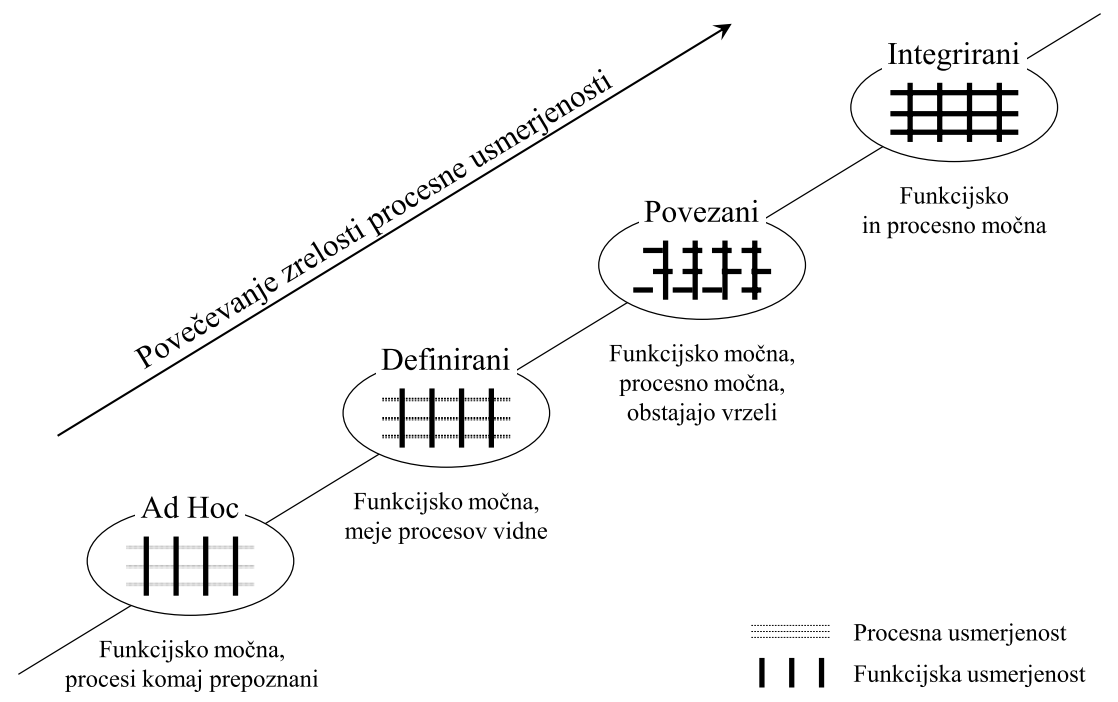

Slika 27: McCormackov zrelostni model

Vir: McCormack 2007, 64.

Da bi organizacija dosegla končni cilj in postala v celoti procesno integrirana, mora skozi posamezne razvojne stopnje. Za organizacije na iz- 
hodiščni stopnji, $A d h c^{2}$, je značilno, da so v ospredju funkcije in vertikalna usmerjenost. Procesi niso strukturirani in so slabo definirani. $\mathrm{Na}$ drugi stopnji, Definirani, so osnovni procesi definirani, izdelani so diagrami poteka. Procesna usmerjenost se začenja uveljavljati, toda funkcije so še vedno v ospredju. Organizacije na tretji stopnji zrelosti, Povezani, prepoznajo strateško pomembnost procesov. Cilji procesov so določeni in poznani v celotni organizaciji. Na najvišji stopnji, Integrirani, je management procesov del organizacijske kulture. Delovna mesta in strukture slonijo na procesih, ki so uveljavljeni enako kot funkcije. Horizontalne strukture so jasno prepoznavne, doseženo je dokončno ravnotežje med procesi in funkcijami. Vzpostavljene meritve procesov ohranjajo horizontalno usmerjenost. Poznavanje procesne usmerjenosti in zrelosti je še posebej pomembno v dobi interneta in uveljavljanja e-omrežij. Ko se povezujejo organizacije na različnih stopnjah procesne usmerjenosti in zrelosti, je nerazumevanje njihove procesne usmerjenosti lahko zelo nevarno, saj lahko nekompatibilnost na tem področju mrežo kaj hitro uniči (McCormack 2007, 72).

\begin{tabular}{|c|c|c|}
\hline $\begin{array}{l}\text { Zrelostna stopnja } 5 \\
\text { Inovativna }\end{array}$ & $\begin{array}{l}\text { Nenehno proaktivno izboljševanje za } \\
\text { doseganje poslovnih ciljev }\end{array}$ & $\begin{array}{l}\text { Načrtovane inovacije } \\
\text { Management sprememb } \\
\text { Zmogljivi procesi }\end{array}$ \\
\hline $\begin{array}{l}\text { Zrelostna stopnja } 4 \\
\text { Napovedljiva }\end{array}$ & $\begin{array}{l}\text { Kvantitativni management procesov } \\
\text { in rezultatov, uporaba koristi } \\
\text { standardizacije }\end{array}$ & $\begin{array}{l}\text { Stabilni procesi } \\
\text { Management znanja } \\
\text { Napovedljivi rezultati }\end{array}$ \\
\hline $\begin{array}{l}\text { Zrelostna stopnja } 3 \\
\text { Standardizirana }\end{array}$ & $\begin{array}{l}\text { Razviti standardne procese, meritve in } \\
\text { usposabljanja za dobavo izdelkov in } \\
\text { storitev }\end{array}$ & $\begin{array}{l}\text { Rast produktivnosti } \\
\text { Uspešna avtomatizacija } \\
\text { Ekonomija obsega }\end{array}$ \\
\hline $\begin{array}{l}\text { Zrelostna stopnja } 2 \\
\text { Managirana }\end{array}$ & $\begin{array}{l}\text { Vzpostaviti disciplinirane delovne } \\
\text { enote, stabilizirati delo in zagotoviti } \\
\text { predanost }\end{array}$ & $\begin{array}{l}\text { Ponovljiva praksa } \\
\text { Manj dodatnih del } \\
\text { Zadovoljiva predanost }\end{array}$ \\
\hline $\begin{array}{l}\text { Zrelostna stopnja } 1 \\
\text { Začetna }\end{array}$ & $\begin{array}{l}\text { Motivirati zaposlene za obvladovanje } \\
\text { problemov in izvedbo nalog }\end{array}$ & $\begin{array}{l}\text { Rast produktivnosti } \\
\text { Uspešna avtomatizacija } \\
\text { Ekonomija obsega }\end{array}$ \\
\hline
\end{tabular}

\section{Slika 28: Kako delujejo zrelostne stopnje v BPMM} Vir: $\mathrm{OMG} 2008,73$.

OMG v definiciji zrelosti procesa dodatno poudari vidik uspešnosti. Zrelost procesa je obseg, $\mathrm{v}$ katerem je proces nedvoumno opredeljen, managiran, merjen, obvladovan in uspešen (OMG 2008, 72-73). Zorenje procesov je posledica rasti zmogljivosti in kaže na intenzivnost procesov ter doslednost, $s$ katero so procesi uvedeni v celotni organizaciji. Izboljše-

2 Ad hoc je fraza latinskega izvora in pomeni $\gg$ za ta namen «. Običajno označuje rešitev, ki je značilna za obravnavo posamezne naloge ali posameznega problema, ne da se je posplošiti in za druge namene ni uporabna. 
vanje procesov zahteva močno podporo vodstva in konsistentno dolgoročno vizijo ter strategijo. Zorenje organizacije poteka skozi izboljševanje infrastrukture in razvijanje organizacijske kulture, ki podpirata uspešno povezovanje procesov, ljudi, metod in orodij. BPMM-model zrelosti poslovnih procesov predstavlja okvir za izvajanje nenehnih izboljšav in inoviranje procesov. Koncept delovanja zrelostnih stopenj prikazuje slika 28.

Stopnje zrelosti predstavljajo lestvico za merjenje dosežene ravni. Dosežena raven pomeni tudi povečano stopnjo zmogljivosti procesov. Vsaka stopnja zrelosti, z izjemo prve, vsebuje določen nabor procesnih področij. BPMM-model ima skupaj 30 procesnih področij, 9 na zrelostni stopnji 2, Io na zrelostni stopnji 3, 5 na zrelostni stopnji 4 in 6 na zrelostni stopnji 5. Stopnja zrelosti se meri skozi doseganje ciljev, ki jih vsebujejo procesna področja na posamezni stopnji. Za začetno stopnjo je značilno, da je uspeh odvisen od kompetenc in prizadevanj posameznikov, ne od uveljavljenih procesov. Cilji še niso določeni. Na začetni stopnji težko govorimo o managementu, z izjemo »gašenja požarov«. Namen druge stopnje je vzpostaviti temelje managementa znotraj delovnih enot. Na tretji stopnji je že vzpostavljen management procesov, osnovna procesna infrastruktura in uporaba ustreznih virov zagotavljata dobavo načrtovanih izdelkov in storitev. Namen četrte stopnje je vzpostavitev managementa zmogljivosti, ki naj izkorišča procesno infrastrukturo in vire za doseganje napovedljivih rezultatov ob obvladljivi variabilnosti. Za najvišjo, peto stopnjo je značilen management sprememb, ki na osnovi preventivnega delovanja zagotavlja nenehno izboljševanje procesov, izdelkov in storitev.

Širši in kompleksnejši pristop ponuja splošen CMMI-okvir oziroma modeli, razviti na njegovi osnovi: CMMI-AQU ${ }^{3}$ za nakup, $\mathrm{CMMI-DEV}^{+}$ za razvoj, CMMI-SVC' za storitve, P-CMM za ljudi in zrelostni model za management podatkov (CMMI Institut 20Io). Vsi CMMI-modeli imajo I6 skupnih glavnih procesnih področij, ki pokrivajo osnovne koncepte in so temelj izboljševanja procesov ne glede na področje uporabe. Procesno področje je definirano kot skupek povezanih praks na nekem področju, ki, kadar so izvedene skupaj, uresničijo vrsto ciljev, pomembnih za izboljšave na tem področju (CMMI Institut 20Io, 487). CMMI-SVC npr. poleg I6 skupnih procesnih področij vključuje še I področje, ki si ga deli z drugimi modeli, in 7 področij, ki so specifična za storitvene dejavnosti skupaj torej 24 procesnih področij. Vsako procesno področje vsebuje zahtevane, pričakovane in informativne komponente. Zahtevane kompo-

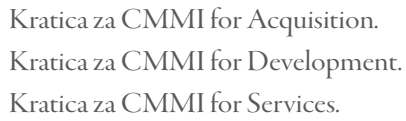


nente so splošni in specifični cilji. Doseganje ciljev je osnova za odločitev o tem, ali so posamezna procesna področja zadovoljivo razvita. Pričakovane komponente so splošne in specifične prakse, torej aktivnosti, potrebne za uresničevanje ciljev. Organizacije jih uporabljajo kot smernice za aktivnosti izboljševanja ali ocenjevanja. Informativne komponente so npr. primeri, razlage in ostale koristne informacije, ki uporabnikom modela omogočajo lažje razumevanje ciljev in praks. CMMI-SVC-stopnje uporablja za opis razvojne poti, ki jo priporoča organizacijam za izboljševanje procesov in zagotavljanje storitev. Na drugi strani so stopnje lahko rezultat ocenjevanja zrelosti (CMMI Institut 20IO, 2I). Možni sta dve poti izboljševanja. Organizacija lahko postopoma izboljšuje izbrani proces z izboljševanjem posameznega procesnega področja oziroma skupine procesnih področij. Druga možnost ponuja izboljševanje skupine procesov glede na izbran nabor procesnih področij. Na tej osnovi model ločuje stopnje zmogljivosti (postopno izboljševanje) ter zrelostne stopnje (stopenjsko izboljševanje). Da bi organizacija dosegla želeno stopnjo bodisi zmogljivosti bodisi zrelosti, mora izpolniti vse cilje izboljšav za posamezno ali skupino procesnih področij. Primerjavo stopenj zmogljivosti in zrelosti prikazuje slika 29.

\begin{tabular}{|l|l|l|}
\hline Stopnja & $\begin{array}{l}\text { Nenehno izbolǰ̌evanje } \\
\text { zmogljivosti }\end{array}$ & $\begin{array}{l}\text { Stopenjsko uresničevanje } \\
\text { zrelosti }\end{array}$ \\
\hline Stopnja 0 & Pomanjkljiv & \\
\hline Stopnja 1 & Izvajan & Začetna \\
\hline Stopnja 2 & Managiran & Managirana \\
\hline Stopnja 3 & Določen & Določena \\
\hline Stopnja 4 & & Kvantitativno managirana \\
\hline Stopnja 5 & & Optimizirana \\
\hline
\end{tabular}

Slika 29: Primerjava stopenj zmogljivosti in zrelosti CMMI

Vir: CMMI Institute 2010, 23.

Van Looy, De Backer in Poels (20 I I, I 126 ) zrelost definirajo kot obseg, $\mathrm{v}$ katerem organizacija $\mathrm{v}$ skladu s svojimi poslovnimi cilji nedvoumno in dosledno uvede procese. V literaturi so na voljo številne podobne definicije zrelosti. CMMI Institut $(2016,484)$ organizacijsko zrelost definira kot obseg, $\mathrm{v}$ katerem organizacija nedvoumno in dosledno uvede procese, $\mathrm{ki}$ so dokumentirani, managirani, merjeni, obvladovani in nenehno izboljševani. Organizacijska zrelost se lahko meri z ocenjevanjem. Raven zrelo- 
sti posameznega procesa je dosežena stopnja izboljševanja procesa glede na vnaprej določen nabor procesnih področij, $v$ katerih so doseženi vsi cilji (CMMI Institut 2010, 483). Stopnja zrelosti je opredeljena kot faza stabilizacije izboljševanja organizacijskih procesov. Na posamezni zrelostni stopnji pomembna skupina procesov organizacije dozori in se pripravi na naslednjo zrelostno stopnjo.

Kategorije

Stopnja

\begin{tabular}{|c|c|c|c|c|}
\hline & Zavedanje & Vzpostavljen & Izboljšan & Prilagojen \\
\hline Menedžment organizacije & $\begin{array}{c}\text { Zavedanje } \\
\text { menedžmenta }\end{array}$ & $\begin{array}{c}\text { Aktivni } \\
\text { menedžment }\end{array}$ & \rangle $\begin{array}{c}\text { Menedžment } \\
\text { je gonilna sila }\end{array}$ & \\
\hline Način dela & $\left.\begin{array}{c}\text { Prestopanje } \\
\text { funkcijskih meja }\end{array}\right\rangle$ & $\begin{array}{l}\text { Uporabljen } \\
\text { proces }\end{array}$ & Izboljšan proces & Prilagojen proces \\
\hline Definiranost procesa & & Definiran & & \\
\hline Dokumentacija & & Dokumentiran & Integriran & \\
\hline Menedžment procesa & & $\begin{array}{c}\text { Aktivni } \\
\text { menedžment }\end{array}$ & $\lambda \begin{array}{l}\text { Menedžment } \\
\text { je gonilna sila }\end{array}$ & \\
\hline Uporabniki procesa & & $\begin{array}{c}\text { Sprejemajo } \\
\text { proces }\end{array}$ & Vključeni & Gonilna sila \\
\hline Meritve & & Nekaj meritev & $\begin{array}{c}\text { Izboljšane } \\
\text { meritve }\end{array}$ & $\begin{array}{c}\text { Nadzorne } \\
\text { meritve }\end{array}$ \\
\hline Izboljševanje & & Vzdrževanje & ) Izboljševanje & $\begin{array}{c}\text { Nenehno } \\
\text { izboljševanje }\end{array}$ \\
\hline
\end{tabular}

Cronemyr in Danielsson (2013, 942) ugotavljata, da začnejo nekatere organizacije management poslovnih procesov uvajati na previsoki stopnji. Pri tem uporabljajo prezahtevne tehnike in orodja, ne da bi predhodno izpolnili potrebne pogoje. Vzrok za to je pogosto nepoznavanje potrebnih pogojev. Zato verjameta, da lahko model zrelosti managementa procesov pomaga organizacijam prepoznati morebitna tveganja in se tako izogniti neuspehom. Razvila sta poenostavljen model in diagnostično orodje za samooceno, ki naj pomaga pri izboljševanju procesov. Avtorja menita, da samoocenitev ponuja celovitejšo in objektivnejšo oceno stanja, kot jo je možno dobiti od zunanjih ocenjevalcev oziroma svetovalcev. Model sestavljajo 4 zrelostne stopnje in predhodna raven. Vsaka od štirih zrelostnih stopenj je osnova za naslednji korak, zato po njunem mnenju model opisuje naravne korake vzpostavitve managementa procesov (Cronemyr in Danielsson 2013, 939). Vodstvo organizacije na prvi stopnji, Zavedanje, pridobi zavedanje o pomenu in koristnosti ukvarjanja s procesi. Na drugi 
stopnji, Vzpostavljen, je proces že definiran z vsemi zahtevanimi elementi. $S$ ciljem trajnosti vodstvo vzpostavi strukturo za vzdrževanje in posodabljanje procesa, spremlja in zahteva rezultate. Na tretji stopnji, izboljšan, se pozornost z modela procesa preseli na podatke o procesu. Vzpostavljene so na odjemalce osredotočene meritve procesa, uveljavljen je ustrezen nadzor procesa, vpeljan je strukturiran pristop izboljševanja, ki sloni na dokazilih. Za proces na četrti stopnji, Prilagojen, velja, da poteka v tesnem sodelovanju z odjemalci ali celo z njihovo vključitvijo $\mathrm{v}$ proces, je prilagodljivejši in proaktivnejši. Statistična kontrola procesa omogoča hitro odzivanje in prilagajanje procesa. Podroben prikaz zrelostnega modela kot osnove diagnostičnega orodja prikazuje slika 30.

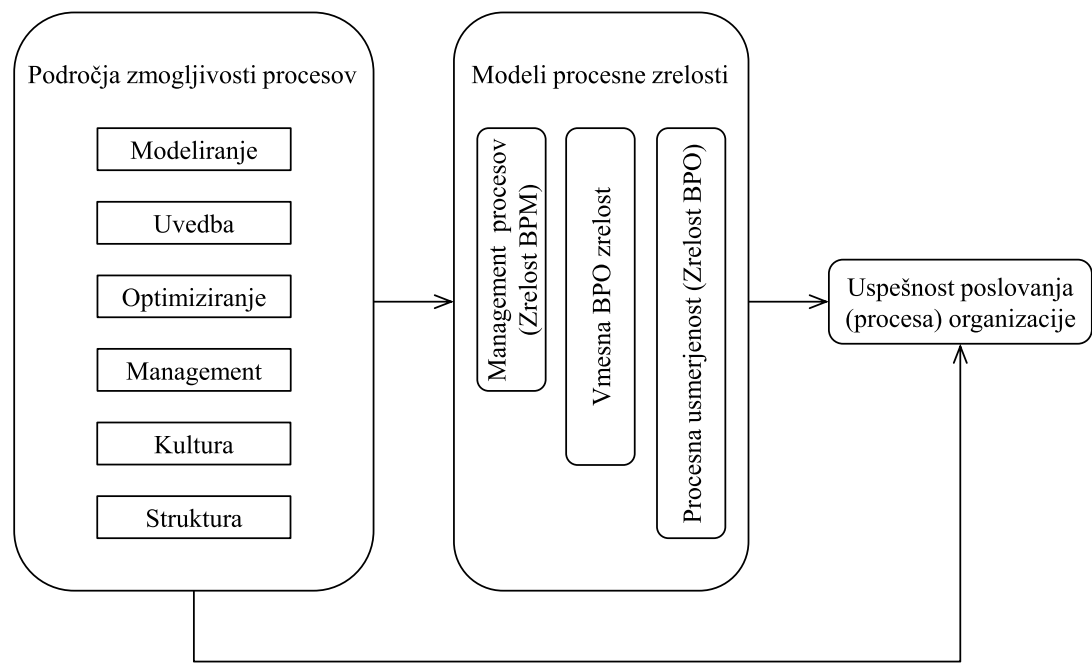

Slika 31: Okvir zmogljivosti procesov in vrste zrelostnih modelov

Vir: Van Looy 2014, 58.

Razvijanje zrelosti organizacije torej pomeni tudi razvijanje zmogljivosti procesov (McCormack 2007). Nekateri avtorji opozarjajo na ne-

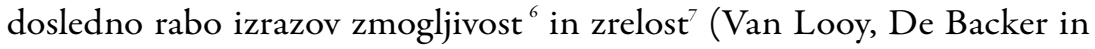
Poels 20 I I, i 25$)$. Izraz zmogljivost, uporabljen v kontekstu procesov, managementa procesov in procesne usmerjenosti, se nanaša zgolj na posamezno področje oziroma komponento zmogljivosti. Pri pregledu literature smo zmogljivosti posameznega procesa več pozornosti posvetili v razdel$\mathrm{ku}$ 3.2.2. Izraz zrelost pa se vedno nanaša na skupek področij zmogljivosti in obseg, v katerem organizacija v skladu s poslovnimi cilji nedvoumno

6 SSKJ: zmogljívost -i ž (i) I. sposobnost koga, določena z dejanjem, delom, ki ga zmore.

7 SSKJ: zrélost -i ž stanje zrelega. 
in dosledno vpelje procese. Odnos med področji zmogljivosti procesov in vrstami zrelostnih modelov prikazuje slika 3 I.

\section{Pregled uveljavljenih modelov zrelosti}

Vse večje število zrelostnih modelov lahko uporabnike v praksi tudi zavede, saj ne znajo izbrati najprimernejšega modela za potrebe lastne organizacije. V nadaljevanju si poglejmo ugotovitve študij in raziskav uveljavljenih zrelostnih modelov procesne usmerjenosti.

Modeli zrelosti so danes vse razvitejši in tudi vse bolj uveljavljen pristop za izboljševanje procesov in BPM (Röglinger, Pöppelbuß in Becker 20I 2, 328). Avtorji so potrebo po sistematičnem pregledu obstoječe literature o zrelostnih modelih utemeljili z vse bolj uveljavljenim spoznanjem, da je za uspešen management poslovnih procesov nujno razvijati zmogljivosti managementa procesov (Rosemann in vom Brocke 2010). $\mathrm{Ob}$ tem je število modelov zrelosti močno naraslo, kar uporabnikom v praksi povzroča vse večje težave pri izbiri pravega modela. $S$ pregledom relevantne literature so avtorji prepoznali najbolj uveljavljene modele zrelosti (preglednica 9).

Preglednica 9: Izbor uveljavljenih javno dostopnih zrelostnih modelov

\begin{tabular}{llll}
\multicolumn{1}{c}{ Kratica } & \multicolumn{1}{c}{ Ime modela } & \multicolumn{1}{c}{ Avtor } & \multicolumn{1}{c}{ Obseg } \\
BPMMM & $\begin{array}{l}\text { Business Process Manage- } \\
\text { ment Maturity Model }\end{array}$ & $\begin{array}{l}\text { Rosemann in de Bruin 2005; } \\
\text { Rosemann idr. 2006 }\end{array}$ & BPM \\
\hline PPI & $\begin{array}{l}\text { Process Performance Index } \\
\text { Rummler-Brache Group } \\
2004\end{array}$ & BPM \\
\hline BPRMM & $\begin{array}{l}\text { Business Process Reingeener- } \\
\text { ing Maturity Model }\end{array}$ & Maull idr. 2003 & BPM \\
\hline BPMM - Fisher & $\begin{array}{l}\text { Business Process Maturi- } \\
\text { ty Model }\end{array}$ & Fisher 2004 & BPM \\
\hline PMMA & $\begin{array}{l}\text { Process Management Matu- } \\
\text { rity Assessment }\end{array}$ & Rohloff 2009 & BPM in procesi na splošno \\
\hline BPOMM & $\begin{array}{l}\text { Business Process Orientation } \\
\text { Maturity Model }\end{array}$ & $\begin{array}{l}\text { McCormack 2007; } \\
\text { McCormack idr. 2009 }\end{array}$ & BPM in procesi na splošno \\
\hline PEMM & $\begin{array}{l}\text { Process and Enterprise Matu- } \\
\text { rity Model }\end{array}$ & Hammer 2007 & BPM in procesi na splošno \\
\hline PML & $\begin{array}{l}\text { Process Maturity Ladder } \\
\text { BPMM - OMG }\end{array}$ & $\begin{array}{l}\text { Business Process Maturi- } \\
\text { ty Model }\end{array}$ & Warmon 2004; 2007 \\
\hline Weber idr. 2008 & BPM in procesi na splošno \\
\hline
\end{tabular}




\begin{tabular}{rlll} 
Kratica & \multicolumn{1}{c}{ Ime modela } & \multicolumn{1}{c}{ Avtor } & \multicolumn{1}{c}{ Obseg } \\
BPMM - Lee & $\begin{array}{l}\text { Business Process Maturi- } \\
\text { tyModel }\end{array}$ & Lee idr. 2007 & $\begin{array}{l}\text { BPM in procesi na } \\
\text { splošno }\end{array}$ \\
\hline
\end{tabular}

Vir: Röglinger, Pöppelbuß in Becker 2012,335.

Avtorji so se omejili na literaturo v angleškem jeziku in modele, ki so javno dostopni oziroma je javno dostopna večina dokumentacije. Ker so se osredotočili na modele zrelosti managementa poslovnih procesov, so iz obravnavanega vzorca izpustili tudi tiste zrelostne modele, ki ocenjujejo samo stanje posameznega procesa, in modele, izpeljane iz CMMI za ocenjevanje določene vrste procesov, npr. procesov razvoja ali nakupa programske opreme in storitvenih procesov. Iz obravnavanega vzorca zrelostnih modelov so izpustili tudi dva sicer večkrat navajana modela, in sicer Strategic Alignment Maturity Model in SOA Maturity Model ${ }^{8}$, ker se le posredno nanašata na management poslovnih procesov (Röglinger, Pöppelbuß in Becker 201 2, 333). Avtorji menijo, da so z izborom desetih zrelostnih modelov, ki jih prikazuje preglednica 9, zajeli najpomembnejše javno dostopne zrelostne modele. Izbrani modeli se med seboj razlikujejo z različnih vidikov. Nekateri so bili razviti v znanstvenih krogih, drugi so nastali v industriji, tretji v mednarodnih konzorcijih. Razlikujejo se tudi po obsegu. Nekateri modeli se nanašajo na ocenjevanje stanja posameznih procesov, torej njihove dokumentiranosti, managementa in rezultatov. Drugi modeli so namenjeni ocenjevanju zrelosti managementa poslovnih procesov (Röglinger, Pöppelbuß in Becker 201 2, 331 ).

Da bi uporabnikom olajšali izbiro primernega zrelostnega modela, so avtorji na osnovi analize 69 zrelostnih modelov (Van Looy 2013, 36-40) in mednarodne študije Delphi razvili odločitveno orodje. Orodje BPMM Smart-Selector je javno dostopno na spletu (http://smart-selector.amyvanlooy.eu/). Na podlagi vprašalnika in I 4 uteženih odločitvenih kriterijev orodje pomaga uporabniku pri izbiri najprimernejšega zrelostnega modela (Van Looy 2014, 69).

Tudi Van Looy (2014) priznava pomemben vpliv filozofije kakovosti na razvoj BPMM-modelov. Toda pravi razvoj zrelostnih modelov je po njenem mnenju spodbudila šele kriza proizvajalcev programske opreme v 70-ih in 80-ih letih prejšnjega stoletja. Prvi zrelostni modeli za procese razvoja programske opreme so nastali v okviru SEI ${ }^{9}$, o čemer smo že pisali v uvodnem delu tega poglavja. Splošni, generični zrelostni modeli pa so

8 SOA je kratica za Service-Oriented Architecture.

9 SEI je kratica za Software Engineering Institute Univerze Carnegie Mellon. 
bili razviti šele konec 9o-ih let oziroma v začetku enaindvajsetega stoletja. Zgodovina BPMM je torej tudi zgodovina SW-inženiringa. V okviru študije avtorji analizirajo literaturo o skupaj kar 69 splošnih zrelostnih modelih poslovnih procesov in procesov $\mathrm{v}$ dobaviteljskih verigah (Van Looy 20I4, 36-40). Na osnovi izsledkov študije avtorji med najširše sprejete in $\mathrm{v}$ različnih panogah uporabljane modele uvrščajo naslednje štiri:

- SEI CMMI (Software Engineering Institute Capability Maturity Model Integration),

- ISO/IEC TR I5504 (ISO/IEC Information technology - Process assessment),

- FAA-iCMM (Federal Aviation Administration Integrated Capability Maturity Model),

- OMG BPMM ${ }^{10}($ Object Management Group Business Process Maturity Model).

O nastanku CMMI-modela oziroma modelov smo pisali že na začetku poglavja. Tudi ISO/IEC TR I5504 se je razvil iz standarda za ocenjevanje procesa razvoja SW. Leta 2003 je postal mednarodni standard, ki, zahvaljujoč nadgradnjam, danes omogoča ocenjevanje tudi drugih vrst procesov. FAA-iCMM se je prav tako razvil iz različic CMM-modela, kasneje vključil vse CMMI-procese, da bi danes omogočal ocenjevanje procesov najzahtevnejših IT-sistemov v storitvenih dejavnostih, tudi na področju varnosti in zaščite sistemov. Leta 2008 je mednarodni konzorcij za tehnološke standarde OMG razvil svoj model zrelosti BPMM, ki se za razliko od prvih treh, ki so vendarle predvsem SW-orientirani, osredotoča na medorganizacijske procese in je primeren za vse vrste organizacij. Vsi štirje modeli so, kljub terminološkim razlikam, organizirani. podobno Ključna procesna področja so razdeljena na podpodročja, za področja so določeni splošni, za podpodročja pa specifični cilji in prakse. Obravnavani modeli so široko sprejeti in jih podpirajo tudi vlada, državne institucije in mednarodne organizacije za standardizacijo (Van Looy 2014, 13I4).

\section{Ocenjevanje ravni zrelosti}

Obravnavani modeli procesne zrelosti ponujajo različne pristope ocenjevanja dosežene stopnje zrelosti.

Harringtonov model ocenjevanja in kvalifikacije procesa sloni na presoji stanja in rezultatov procesa, ki jo izvede vodstveni tim s skrbnikom procesa. Osnova za pregled je celovito poročilo o stanju procesa. $\mathrm{Na}$ 
tej osnovi ocenjevalci preverijo izpolnjevanje določenih kriterijev za naslednjo zrelostno stopnjo (Harrington 1991, 215). Tudi CMM-model (Paulk idr. 1993) zahteva ocenjevalno skupino in celovito presojo. Običajni koraki ocenjevanja vključujejo izbor skupine, izpolnjevanje vprašalnika in uporabo drugih orodij, analizo odgovorov, intervjuje in pregled dokumentov na lokaciji, ocenjevanje doseganja ciljev ključnih procesnih področij ter oblikovanje ugotovljenih prednosti in priložnosti za izboljšave ter izdelavo profila ključnih procesnih področij. Oba opisana pristopa ocenjevanja stopnje procesne zrelosti sta zahtevna tako z vidika vključenih človeških virov kot potrebnega časa, a omogočata pravilnejšo in natančnejšo oceno.

McCormack (2007, 255-57) za ocenjevanje uporabi vprašalnik s 35 vprašanji, ki jih posreduje 20 do 30 ključnim respondentom. Vprašanja pokrivajo 7 področij, in sicer: procesni pogled, procesne naloge, management procesov in sistem merjenja, medorganizacijske konflikte in medorganizacijsko povezanost, občutek ponosa in lojalnosti ter splošno oceno uspešnosti organizacijske enote.

Cronemyr in Danielsson (2013, 940) sta za diagnosticiranje stopnje zrelosti procesa razvila ločena vprašalnika s po približno 40 vprašanji. Prvi vprašalnik je namenjen lastniku procesa, ki je odgovoren za management procesa, drugi vprašalnik pa uporabnikom procesa. Vprašanja imajo vnaprej določene možne odgovore, ki onemogočajo napačno tolmačenje vprašanj.

Merjenje zmogljivosti in zrelosti zahteva ocenjevanje obstoječe ravni (angl. AS-IS) na osnovi prednosti in slabosti v primerjavi s praksami ter cilji modela. Osnova za ocenjevanje so različne tehnike zbiranja podatkov, izračuni in predstavitve. Ocenjevanje je lahko notranje, ko ga izvaja organizacija sama (prva stranka), ali zunanje. Zunanje ocenjevanje lahko izvajajo partnerji ali drugi deležniki (ocenjevanje s strani druge stranke) ali celo za to akreditirane organizacije (ocenjevanje s strani tretje stranke). Ko organizacija zrelostni model uporabi za izboljševanje, sledita v skladu s cilji organizacije najprej določitev želene stopnje (angl. TO-BE) ter analiza vrzeli, ki je osnova za opredelitev potrebnih izboljšav. Zadnji korak je razvrstitev izboljšav po pomembnosti in določitev poti iz obstoječega $\mathrm{v}$ želeno stanje (Van Looy, De Backer in Poels 20I I, I I33).

\section{Uporabnost zrelostnih modelov in kritike}

Smith in Fingar 2004 opozarjata, da na osnovi CMM zasnovani modeli zrelosti, ki poudarjajo dobro organizirane in ponovljive procese, ne morejo zajeti potreb po inoviranju procesov. Škrinjar (2010, I90) ugotavlja, 
da so $\mathrm{v}$ zrelostnih modelih različnih avtorjev sicer navedene dobre prakse, ki naj jih organizacije uvedejo, vendar te prakse bodisi niso povezane $s$ konkretno stopnjo zrelosti bodisi so določene povsem arbitrarno. Röglinger, Pöppelbuß in Becker (20I2, 330-3I) analizirajo zrelostne modele $\mathrm{z}$ vidika njihove uporabnosti in koristnosti. Analizo izvedejo z uporabo okvira splošnih načel oblikovanja zrelostnih modelov, ki sta ga leta 20 I I predlagala Pöppelbuß in Röglinger. Model vsebuje tri skupine načel, in sicer osnovna načela oblikovanja zrelostnih modelov, načela oblikovanja za opisni namen uporabe in načela oblikovanja za normativni namen uporabe zrelostnih modelov. Model zrelosti služi opisnemu namenu, ko ga je moč uporabljati za ocenjevanje dejanskega stanja (angl. AS-IS). Normativnemu namenu služi model takrat, ko nakazuje, kako prepoznati prihodnje želene ravni zrelosti, in zagotavlja smernice za potrebne ukrepe ter izboljšave. Primerjalnemu namenu pa služi model takrat, ko omogoča notranje in zunanje primerjave. Avtorji ugotavljajo, da so modeli praviloma primerni za opisni namen uporabe, saj vsebujejo kriterije za ocenjevanje dejanskega stanja. Ti kriteriji ocenjevanja so pogosto zgolj v opisni obliki. Pogrešajo pa izčrpnejše in bolj strukturirane, a za uporabo enostavne ocenjevalne kontrolne sezname. Za normativni namen uporabe pa so obravnavani modeli komajda uporabni, saj vključujejo le zelo omejen nabor smernic za izbor in določanje pomembnosti potrebnih ukrepov ter izboljšav.

\section{Povzetek pregleda literature}

Organizacije $\mathrm{z}$ razvijanjem zmogljivosti procesov, managementa procesov in procesne usmerjenosti dosegajo višnje stopnje zrelosti in s tem odličnosti procesov ter rezultatov. Zrelostni modeli organizacijam pomagajo oceniti doseženo stopnjo na poti $\mathrm{v}$ odličnost poslovnih procesov. $\mathrm{V}$ dobrih dveh desetletjih je bilo razvitih na desetine modelov procesne zrelosti. Razvoj in popularizacija zrelostnih modelov procesne zrelosti temeljita predvsem na CMM-modelu zrelosti procesa razvoja programske opreme, ki ga je v začetku 90-ih let razvil inštitut SEI Unniverze Carnegie Mellon. Čeprav so si modeli v osnovnem konceptu stopenj oziroma korakov na poti v odličnost zelo podobni, pa se razlikujejo v številnih drugih značilnostih. Nekateri modeli veljajo samo za določeno vrsto procesov, drugi splošno za vse procese. Glede na obseg ocenjevanja lahko zrelostne modele delimo v 3 skupine: za ocenjevanje zrelosti procesov, zrelosti managementa procesov in zrelosti procesne usmerjenosti. $\mathrm{V}$ obravnavanih modelih se število zrelostnih stopenj giblje med 3 in 6. Številni modeli so javno dostopni, tudi večina njihove dokumentacije. Modeli, ki so intelektualna 
lastnina raziskovalnih inštitutov in svetovalnih organizacij, ki prodajajo storitve na tem področju, so dostopni le proti plačilu. Pomembne razlike med modeli so tudi glede načina določanja dosežene stopnje zrelosti. Pri nekaterih modelih to sloni na ocenjevanju oziroma primerjavi z opisi posameznih stopenj, drugi uporabljajo merjenje z vprašalniki, ki vključujejo različne elemente. Kritike modelov opozarjajo na to, da modeli vsebujejo vse premalo konkretnih smernic in napotkov za določanje potrebnih ukrepov ter izboljšav. Ob tem še ni celovite primerjalne študije zrelostnih modelov z vidika njihove uporabnosti in koristnosti pri povečevanju uspešnosti procesov ter poslovne uspešnosti organizacij. Veliko število različnih modelov pa uporabnike $\mathrm{v}$ praksi postavlja pred resne dileme, kako izbrati pravi model za lastne potrebe. 


\section{Predstavitev elektroenergetske dejavnosti}

Brez električne energije si danes ni mogoče predstavljati ne življenja ne razvoja. V vsakem trenutku nas obkroža množica naprav, ki so brez električne energije zgolj mrtvi, neuporabni predmeti. Da bi delovali, nam omogočali delo, ustvarjanje in razvoj pa tudi varnost, udobje in še veliko drugega, morajo biti priključeni na izvor napajanja. Za temi izvori pa je izjemno kompleksen in mednarodno močno vpet elektroenergetski sistem, ki 24 ur na dan, vse dni v tednu, zagotavlja varno, zanesljivo in neprekinjeno oskrbo z električno energijo. Prav pomen elektroenergetskega sistema in dejavnosti za delovanje ter razvoj celotne družbe je bil eden od razlogov za merjenje procesne usmerjenosti v tej dejavnosti.

Družbe elektrogospodarstva pa niso pomembne zgolj zaradi uresničevanja svojega poslanstva, tj. proizvodnje, prenosa in razdeljevanja električne energije. Družbe v tej dejavnosti ustvarjajo tudi pomembne finančne učinke in zaposlujejo veliko število ljudi. V letu 2014 so družbe elektrogospodarstva in premogovništva ustvarile skupni dobiček v višini 99,4 mio EUR in zaposlovale povprečno 6.386 zaposlenih (Republika Slovenija, Ministrstvo za infrastrukturo 2015b, 7).

\section{Elektroenergetski sistem}

Elektroenergetski sistem sestavljajo vsi postroji in naprave za proizvodnjo, prenos ter razdeljevanje električne energije, ki zagotavljajo vzdrževanje ravnotežja med proizvodnjo in porabo $\mathrm{z}$ ustreznimi regulacijami (Sloko CIGRÉ 200I, 7). 
Proizvodnja električne energije na javnem omrežju v Sloveniji je, upoštevajoč celotno proizvodnjo Jedrske elektrarne Krško, v letu 2014 znašala 16.28I gigavatnih ur (GWh) oz. I325 več kot leta 2013 . V strukturi proizvedene električne energije predstavlja največji, 37-odstotni delež, jedrska elektrarna, sledijo hidroelektrarne s 36-odstotnim deležem, termoelektrarne z 20- in mali proizvajalci na distribucijskem omrežju s 7-odstotnim deležem. Struktura proizvodnje se počasi spreminja. Raste delež jedrske elektrarne in hidroelektrarn, postopoma pa se povečuje tudi delež malih proizvajalcev. Skupna neto poraba električne energije je v Sloveniji v letu 20I4, brez upoštevanja sistemskih izgub na prenosnem in distribucijskem omrežju, znašala I 2.7 I9 GWh in je bila za $0,8 \%$ manjša kot v letu 2013. V strukturi porabe predstavljajo daleč največji delež, kar 72,6 $\%$, poslovni odjemalci, sledijo gospodinjski odjemalci s $24,6 \%$ in črpalna elektrarna Avče z 2,8 \%. Vseh odjemalcev električne energije je bilo leta 2014 v Sloveniji 936.883. Oddaja energije v tujino je v letu 2014 znašala $9.996 \mathrm{GWh}$, celoten uvoz na prenosnem in distribucijskem omrežju pa 7.254 GWh. Pokritost slovenske porabe z domačimi proizvodnimi viri je v letu 2014 znašala 98 \% (Republika Slovenija, Ministrstvo za infrastrukturo 2015a, 7-15).

Skupna sistemska dolžina daljnovodov visokonapetostnega prenosnega omrežja znaša $2.843 \mathrm{~km}$, od tega je $13,3 \mathrm{~km}$ kablovodov $(669 \mathrm{~km} 400$ kilovoltnega (kV) omrežja, $328 \mathrm{~km} 220 \mathrm{kV}$ in $1.846 \mathrm{~km}$ I Io kV omrežja). Prenosno omrežje povezuje skupaj 3 I postaj s 27 energetskimi transformatorji (ELES 2015, 21).

Distribucijsko omrežje povezuje prenosno omrežje s priključnimi merilnimi mesti posameznih odjemalcev in tako omogoča razdeljevanje električne energije. Razdeljevanje poteka na visokonapetostnem nivoju (VN) i I $\mathrm{kV}$, na srednjenapetostnih nivojih (SN) $35 \mathrm{kV}$, $20 \mathrm{kV}$ in Io $\mathrm{kV}$ ter nizkonapetostnem nivoju (NN) o,4 kV. Celotno distribucijsko omrežje vseh petih elektrodistribucijskih podjetij obsega $850 \mathrm{~km} \mathrm{VN}$ omrežja, $16.803 \mathrm{~km} \mathrm{SN}$ omrežja in $46.197 \mathrm{~km} \mathrm{NN}$ omrežja. Omrežje povezuje 87 razdelilnih transformatorskih postaj VN/SN in 15.229 transformatorskih postaj SN/NN (Carli 2015, I3).

\section{$\operatorname{Trg} \mathrm{z}$ električno energijo}

Slovenski trg z električno energijo je integralni del skupnega energetskega trga Evropske skupnosti. S krovnim »Energetskim zakonom« (EZ-I), ki je stopil v veljavo 22. marca 2014 , je Slovenija v celoti uveljavila tretji sveženj evropske energetske zakonodaje (Republika Slovenija, Ministrstvo 
za infrastrukturo 20 I5a, 5). Model oskrbe z električno energijo v Sloveniji prikazuje slika 32.

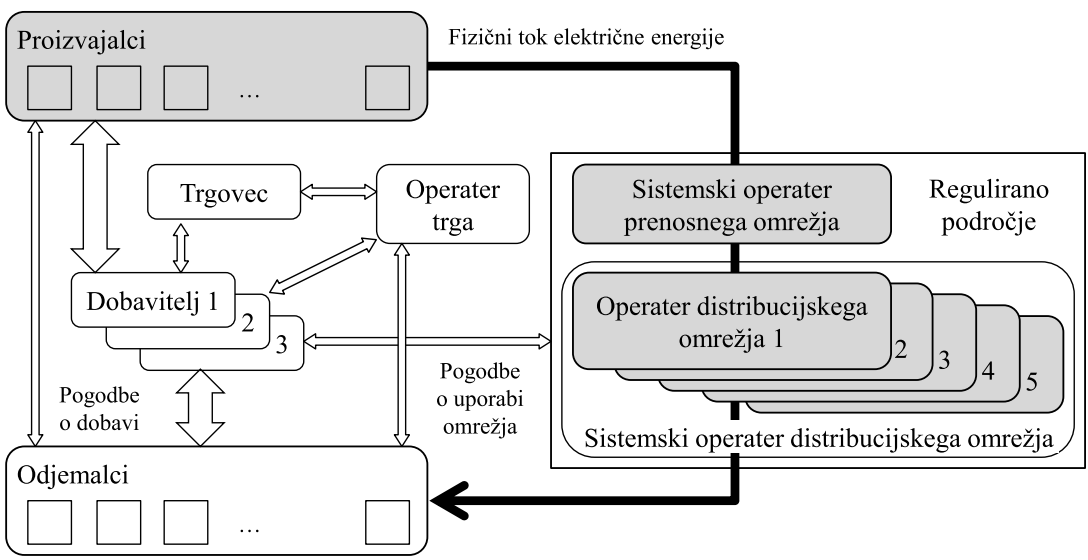

Deležniki trga z električno energijo so proizvajalci, sistemski operater prenosnega omrežja (SOPO) in sistemski operater distribucijskega omrežja (SODO), operaterji distribucijskih omrežij, operater trga, trgovci in dobavitelji ter seveda odjemalci. Proizvodnja, trgovanje in dobava so tržne dejavnosti. Trg z električno energijo je popolnoma odprt od r. julija 2007. To vsakemu odjemalcu omogoča, da prosto izbira svojega dobavitelja električne energije, tudi z vidika načina proizvodnje in uporabljenih energetskih virov. Okoljsko ozaveščeni odjemalci imajo tako možnost izbirati električno energijo, proizvedeno na okolju prijaznejši način, iz obnovljivih virov energije, ali proizvedeno $\mathrm{v}$ objektih za soproizvodnjo toplote in električne energije (Agencija za energijo 2016). Usklajeno delovanje slovenskega elektroenergetskega sistema zagotavlja družba Borzen, organizator trga z električno energijo, d. o. o.

Prenos in distribucija električne energije pa sta netržni oziroma regulirani dejavnosti. Energetski regulativni organ je Agencija za energijo Republike Slovenije. Na področju električne energije agencija spremlja, usmerja in nadzira izvajalce energetskih dejavnosti. Celovito spremlja delovanje energetskega trga in njegovo konkurenčnost ter zagotavlja preglednost njegovega delovanja. Upoštevajoč državno energetsko politiko usklajuje interese vseh deležnikov. Med ključne cilje agencije sodi tudi spodbujanje razvoja varnih, zanesljivih in stroškovno učinkovitih prenosnih ter distribucijskih sistemov za električno energijo in doseganje naj- 
večje koristi za odjemalce $\mathrm{z}$ zagotavljanjem konkurenčnih pogojev ter učinkovitega delovanja trga (Agencija za energijo 20I5, II-I4). $\mathrm{Z}$ reguliranjem pogojev poslovanja SOPO, SODO in operaterjev distribucijskih omrežij agencija pomembno vpliva na poslovno uspešnost teh družb.

\section{Organiziranost elektroenergetske dejavnosti}

V nadaljevanju na kratko predstavljamo organiziranost družb s področja proizvodnje, prenosa in distribucije električne energije, ki smo jih vključili v empirično raziskavo. Obravnavamo samo organizacije, ki omogočajo fizičen tok električne energije in zagotavljajo kakovostno, varno in zanesljivo oskrbo odjemalcev z električno energij (na sliki $32 \mathrm{v}$ sivi barvi).

\section{Proizvodnja električne energije}

V razdelku 6.I smo že omenili, da proizvodnja električne energije v Sloveniji poteka v jedrski elektrarni v Krškem, v hidroelektrarnah, termoelektrarnah, v enotah malih proizvajalcev, ki so priključene neposredno na distribucijsko omrežje, ter v Energetiki Ljubljana, d. o. o., s sočasno proizvodnjo toplote in električne energije. Mali proizvajalci v našo raziskavo niso bili vključeni, zato jih v nadaljevanju ne obravnavamo. Statusno je $93 \%$ proizvodnje električne energije organizirane v dveh stebrih, in sicer v skupini GEN in skupini Holding Slovenske elektrarne.

Skupina GEN kar 99,7 \% električne energije proizvede iz trajnostnih, nizkoogljičnih virov energije: jedrske, vodne in sončne energije. Poleg matične družbe GEN energija, d. o. o., sestavljajo skupino naslednje proizvodne družbe: Nuklearna elektrarna Krško, d. o. o. (letna proizvodnja ca. 5.400 GWh), Savske elektrarne Ljubljana, d. o. o. (ca. 320 GWh), Termoelektrarna Brestanica, d. o. o. (pokrivanje izpadov večjih proizvodnih enot in zagotavljanje sistemske rezerve), Hidroelektrarne na Spodnji Savi, d. o. o. (ca. 400 GWh), in Srednjesavske elektrarne, d. o .o. (sodelovanje v projektu izgradnje hidroelektrarn na spodnji Savi, v začetni fazi). Celotna skupina proizvede ca. $40 \%$ v Sloveniji proizvedene električne energije. Po oddaji hrvaškega dela električne energije iz NEK je v letu 2014 delež proizvodnje skupine GEN v Sloveniji znašal $30 \%$. V vseh družbah skupine je bilo v letu 2014 I.I80 zaposlenih (GEN skupina 20I5).

Skupina HSE je največja organizacija s področja elektroenergetike in največji proizvajalec električne energije v Sloveniji. Poleg krovne družbe Holding Slovenske elektrarne, d. o. o., skupina vključuje naslednje družbe za proizvodnjo električne energije: Dravske elektrarne Maribor, d. o. o. (proizvodnja v 20143.919 GWh), Soške elektrarne Nova Gorica, d. o. 
o. (99I GWH), in Termoelektrarno Šoštanj, d. o. o. (2.835 GWh). Sestavni del skupine je tudi družba Premogovnik Velenje, d. o. o., ki zagotavlja premog za proizvodnjo v Termoelektrarni Šoštanj in smo jo prav tako vključili v merjenje zrelosti procesne usmerjenosti. Skupina je v letu 2014 proizvedla $8.294 \mathrm{GWh}$ električne energije, $64 \%$ virov predstavljajo hidroelektrarne, $36 \%$ pa termoelektrarne. V skupini je bilo leta 2014 I.32 I zaposlenih (HSE 2015).

\section{Prenos električne energije}

Prenosno omrežje predstavlja hrbtenico elektroenergetskega sistema. Sistemski operater prenosnega omrežja, družba ELES, d. o. o., s svojim omrežjem povezuje štiri glavne udeležence elektroenergetskega sistema: elektrarne za proizvodnjo električne energije, prenosna omrežja sosednjih držav, s katerimi Slovenija izmenjuje električno energijo (Avstrija, Italija in Hrvaška), 5 distribucijskih podjetij ter 5 velikih neposrednih odjemalcev električne energije iz prenosnega omrežja (železarne in Talum). Zaradi svoje geografske lege ima Slovenija izjemno pomembno vlogo pri mednarodnem prenosu električne energije. ELES omogoča vključenost Slovenije v skupen evropski energetski trg in čezmejno trgovanje z električno energijo. V letu 2014 je bilo na dan 3I. I2. tam 532 zaposlenih (ELES 2014, 20).).

\section{Distribucija električne energije}

Slovenija je geografsko razdeljena na pet organizacij za distribucijo električne energije: Elektro Celje, d. d., Elektro Gorenjska, d. d., Elektro Ljubljana, d. d., Elektro Maribor, d. d., in Elektro Primorska, d. d. Vseh pet družb izvaja enako poslanstvo distribucije električne energije. Razlike med njimi so pogojene predvsem z geografskimi značilnostmi ter s številom, strukturo in z značilnostmi njihovih odjemalcev. Družbe imajo distribucijsko omrežje v najemu od sistemskega operaterja distribucijskega omrežja. Slovenska elektrodistribucija z več kot ıoo-letno tradicijo razvija in vzdržuje več kot $64.000 \mathrm{~km}$ dolgo omrežje in na $21.000 \mathrm{~km}^{2} \mathrm{z}$ električno energijo oskrbuje 933.000 odjemalcev. V letu 2014 je bilo v matičnih družbah več kot 3.000 zaposlenih (Ponebšek 2015, 3). Dejavnost elektrodistribucije je regulirana dejavnost. Agencija za energijo z določanjem pogojev poslovanja in določanjem višine omrežnine za distribucijsko omrežje v veliki meri vpliva tudi na rezultate poslovanja organizacij s področja elektrodistribucije. 



\section{Merjenje zrelosti procesne usmerjenosti v elektroenergetski dejavnosti}

\section{Kvantitativni del raziskave}

Že v uvodu v poglavje 6 smo poudarili pomen elektroenergetske dejavnosti za življenje, za delovanje in razvoj celotne družbe. Z vidika našega preučevanja so organizacije elektroenergetske dejavnosti zanimive tudi zato, ker se s procesi in procesnim pristopom ukvarjajo že vrsto let. Večina organizacij ima certifikat za sistem vodenja kakovosti po zahtevah standarda ISO 900ı. Standard, kot smo širše predstavili v razdelku 2.4, zahteva uporabo procesnega pristopa. Poleg tega organizacije že zaradi same narave dejavnosti veliko virov in naporov usmerjajo v avtomatizacijo in informatizacijo poslovanja tako na tehničnem področju kot v poslovnem delu. Avtomatizacija in informatizacija pa zahtevata jasno opredeljene in dokumentirane procese.

\section{Namen in cilji raziskave}

$\mathrm{V}$ okviru empirične raziskave smo izmerili doseženo raven zrelosti procesne usmerjenosti v elektroenergetski dejavnosti. Eden od pomembnih razlogov za izvedbo merjenja prav v elektroenergetski dejavnosti je pomembnost dejavnosti za delovanje in razvoj celotne družbe, kar smo predstavili v poglavju 6. V merjenje smo vključili organizacije s področja proizvodnje, prenosa in distribucije električne energije, ki omogočajo fizičen tok električne energije in zagotavljajo kakovostno, varno in zanesljivo oskrbo odjemalcev z električno energijo (sivo obarvana območja na sliki 32). Zaradi izvajanja pomembnih glavnih in podpornih procesov fizične verige smo v raziskavo vključili tudi družbi HSE Invest, d. o. o., ki znotraj 
skupine HSE izvaja inženiring in izgradnjo energetskih objektov ter storitve svetovalnega in izvajalskega inženiringa, ter Informatika, d. d., ki za nekatere družbe v obravnavani verigi izvaja IT-storitve.

Za uresničitev prvega cilja raziskave smo pregledali del obsežne literature s področja procesov, managementa poslovnih procesov in procesne usmerjenosti. Za uresničitev drugega cilja smo pregledali relevantno literaturo o uveljavljanju koncepta procesne zrelosti in uveljavljenih zrelostnih modelih. Posebno pozornost smo namenili najnovejšim znanstvenim in strokovnim člankom ter študijam vpliva procesne usmerjenosti na uspešnost poslovanja organizacij ter koristnosti uporabe zrelostnih modelov za uveljavljanje in razvijanje procesne usmerjenosti. Za uresničitev tretjega cilja smo v obdobju od 19. februarja do 23. marca 2016 izvedli merjenje zrelosti procesne usmerjenosti $\mathrm{v}$ ig organizacijah elektroenergetske dejavnosti Slovenije.

\section{Metode za doseganje ciljev}

Prva dva cilja raziskave smo uresničili s pregledom dosegljive literature. Obravnavano področje je $\mathrm{z}$ različnih vidikov obdelano $\mathrm{v}$ številnih strokovnih in znanstvenih člankih ter knjigah. Prav obseg literature predstavlja eno od omejitev raziskave. Čeprav smo preučili vrsto znanstvenih in strokovnih člankov, objavljenih v zadnjih nekaj letih, obstaja verjetnost, da $\mathrm{v}$ pregled literature nismo vključili vseh pomembnih teoretičnih prispevkov na področju procesne usmerjenosti in zrelostnih modelov.

Merjenje procesne usmerjenosti smo izvedli s pomočjo vprašalnika za razširjen koncept procesne usmerjenosti z devetimi elementi (Škrinjar 2010) in tako zagotovili primarni vir podatkov za raziskavo. Anketirani so vprašalnik izpolnjevali tako, da so izrazili stopnjo strinjanja oziroma nestrinjanja s postavljenimi trditvami. $\mathrm{V}$ ta namen je uporabljena 7 -stopenjska Likertova lestvica, ki daje dovolj možnosti za izražanje stopnje strinjanja. Ocena I pomeni, da trditev sploh ne drži, ocena 7 pa, da trditev popolnoma drži. Vmesne stopnje odražajo stopnjo strinjanja, pri čemer višje stopnje strinjanja pomenijo bolj uveljavljeno procesno usmerjenost. Srednja ocena 4 pomeni neopredeljenost anketiranca (niti ne drži niti ne drži). Dve trditvi, zadnja trditev elementa $Q_{7}$ IV, Procesna organizacijska struktura, in tretja trditev elementa Q I I VI, Procesna organizacijska kultura, sta bili s ciljem preverjanja verodostojnosti odgovorov anketirancev postavljeni negativno (višja stopnja strinjanja pomeni nižjo raven uveljavljenosti procesne usmerjenosti). Odgovore na ti vprašanji smo pred analizo zrcalno prekodirali (Škrinjar 20ı, I03). Odgovori na vprašanji $Q_{3}$ in $Q_{4} o$ številu glavnih in podpornih procesov v organiza- 
ciji nam služijo kot dodatno pojasnilo k trditvi, da so v organizaciji definirani glavni in podporni poslovni procesi. Drugače kot ostale trditve so bile postavljene tudi trditve pri vprašanju Q8 glede najvišjega rangiranega zaposlenega, odgovornega za procese (štirje možni odgovori), in Q9 glede tega, ali organizacija ima posebno organizacijsko enoto ali del enote, namenjene BPM (možen samo en odgovor: da ali ne). Tudi odgovori na ti dve vprašanji v statistično analizo niso vključeni. Anketiranje smo izvedli elektronsko, s pomočjo odprtokodne aplikacije I KA in spletnega portala EnKlikAnketa. Vprašalnik (glej prilogo I) smo predhodno preskusili na testnem vzorcu 34 respondentov v eni od organizacij dejavnosti.

Zanesljivost vprašalnika smo preverili s Cronbachovim koeficientom alfa. Iz preglednice ıo je razvidno, da so izidi raziskave zanesljivi, saj Cronbachov koeficient alfa znaša o,847.

Preglednica ı: Statistika zanesljivosti anketnega vprašalnika

Pridobljene podatke smo statistično obdelali v programskem orodju SPSS. Izvedli smo opisno statistiko (izračun frekvenc, srednjih vrednosti in standardnega odklona), korelacijsko analizo, faktorske analize in t-test za neodvisne vzorce.

Za ugotavljanje stopnje zrelosti smo uporabili McCormackov 4-stopenjski zrelostni model, ki ga prikazuje slika 27. Glede na uporabljeno 7-stopenjsko Likertovo lestvico smo meje zrelostnih stopenj na osnovi srednjih vrednosti ocen odgovorov opredelili na naslednji način (Škrinjar 2010, 152):

- ad hoc: do vključno 4, kar je odraz nestrinjanja oziroma odsotnosti strinjanja s trditvami,

- definirani: od 4,or do vključno 5,5, kar odraža zmerno strinjanje $s$ trditvami,

- povezani: od 5,5 I do vključno 6,5, kar je odraz strinjanja s trditvami v večji meri, in

- integrirani: od 6,5 I do 7, kar pomeni, da so respondenti za večino trditev izrazili najvišjo stopnjo strinjanja 7. 


\section{Opis vzorca}

$\mathrm{V}$ namenski vzorec smo vključili vodje vseh treh ravni vodenja, torej vrhnji, srednji in nižji management, ter vodje projektov. Povabilo k izpolnjevanju vprašalnika je bilo vodjem v veliki večini organizacij poslano $s$ strani oziroma s podporo predsednikov uprav, generalnih direktorjev oziroma direktorjev družb na uveljavljen notranji način komuniciranja. Raziskavo je s svojim povabilom organizacijam $\mathrm{k}$ izpolnjevanju vprašalnika podprla tudi Sekcija za kakovost in odličnost v elektroenergetiki. Prav zaradi načina izvedbe anketiranja ne poznamo dejanske velikosti populacije in vzorca vodij, ki jim je bila anketa posredovana, kar predstavlja eno od omejitev raziskave. Glede na naše poznavanje organizacijskih struktur nekaterih organizacij, s katerimi sodelujemo, in dejavnosti je velikost populacije približno 450 managerjev. Vzorec anketiranih je zajel celotno populacijo, tj. 450 managerjev. Je pa na drugi strani prav uporabljeni način anketiranja prispeval k pričakovani višji odzivnosti anketirancev. Prejeli smo $240 \mathrm{v}$ celoti izpolnjenih vprašalnikov, kar je glede na ocenjeno populacijo 53,33-odstotna odzivnost.

Preglednica ı г: Demografski podatki anketiranih managerjev

\begin{tabular}{|c|c|c|c|}
\hline Karakteristike & Deskriptor & f & $f \%$ \\
\hline \multirow{3}{*}{ Položaj } & $\begin{array}{l}\text { Predsednik uprave ali generalni direktor oz. direktor družbe, član uprave, } \\
\text { pomočnik predsednika uprave oziroma direktor družbe }\end{array}$ & I5 & 6,3 \\
\hline & Direktor oziroma izvršni direktor organizacijske enote (področja, sektorja) & I8 & 7,5 \\
\hline & Vodja službe, vodja enote, vodja oddelka, vodja projekta & 207 & 86,3 \\
\hline \multirow{3}{*}{ Delovne izkušnje } & Do io let & 15 & 6,3 \\
\hline & Nad Io do 30 let & 149 & 62,1 \\
\hline & Nad 30 let & 76 & 31,7 \\
\hline \multirow{6}{*}{$\begin{array}{l}\text { Skupina oziroma } \\
\text { organizacija }\end{array}$} & Skupina GEN & 14 & 5,8 \\
\hline & Holding Slovenske Elektrarne & 37 & 15,4 \\
\hline & Energetika Ljubljana, enota TE-TOL & I & 0,4 \\
\hline & ELES & 88 & 36,7 \\
\hline & Elektrodistribucijsko podjetje & 97 & 40,4 \\
\hline & Informatika & 3 & 1,3 \\
\hline Skupaj & & 240 & 100,0 \\
\hline
\end{tabular}

Največ izpolnjenih vprašalnikov smo prejeli od vodij služb, vodij enot, vodij oddelkov oziroma vodij projektov $(86,3 \%)$, z delovnimi izkušnjami nad ıo do 30 let (62, I \%), ki so zaposleni v enem od elektrodistri- 
bucijskih podjetij (40,4\%). Demografske podatke anketiranih managerjev prikazuje preglednica I I.

Kot prikazuje preglednica I2, so se elektrodistribucijska podjetja kot skupina na povabilo za sodelovanje $\mathrm{v}$ raziskavi odzvala pozitivno. Največ izpolnjenih vprašalnikov smo prejeli iz Elektra Maribor ( $13,8 \%$ ). Iz skupine HSE smo največ izpolnjenih vprašalnikov prejeli iz Dravskih elektrarn Maribor (4,6 \%). Najslabši je bil odziv v skupini GEN, znotraj katere smo iz Savskih elektrarn prejeli 6 izpolnjenih vprašalnikov $(2,5 \%)$.

Preglednica I2: Demografski podatki anketiranih oseb znotraj posameznih skupin GEN,

HSE in elektrodistribucijskih podjetij

\begin{tabular}{|c|c|c|c|}
\hline \multirow{2}{*}{ GEN } & Gen energija & 8 & 3,3 \\
\hline & Savske elektrarne Ljubljana & 6 & 2,5 \\
\hline \multicolumn{2}{|l|}{ Skupaj } & 14 & 5,8 \\
\hline \multirow{6}{*}{ HSE } & Holding Slovenske elektrarne & 10 & 4,2 \\
\hline & Dravske elektrarne Maribor & II & 4,6 \\
\hline & Soške elektrarne Nova Gorica & 2 & 8 \\
\hline & Termoelektrarna Šoštanj & I &, 4 \\
\hline & Premogovnik Velenje & IO & 4,2 \\
\hline & HSE Invest & 3 & 1,3 \\
\hline \multicolumn{2}{|l|}{ Skupaj } & 37 & 15,4 \\
\hline \multirow{5}{*}{$\begin{array}{l}\text { Elektrodistribucijsko } \\
\text { podjetje }\end{array}$} & Elektro Celje & 18 & 7,5 \\
\hline & Elektro Gorenjska & $\mathrm{I} 2$ & 5,0 \\
\hline & Elektro Ljubljana & 16 & 6,7 \\
\hline & Elektro Maribor & 33 & 13,8 \\
\hline & Elektro Primorska & 14 & 5,8 \\
\hline \multicolumn{2}{|l|}{ Skupaj } & 97 & 40,4 \\
\hline
\end{tabular}

\section{Zrelost procesne usmerjenosti}

Anketirani so na posamezne trditve s področja procesne usmerjenosti odgovarjali na Likertovi lestvici od I (sploh ne drži) do 7 (popolnoma drži). Anketirani se v povprečju strinjajo (preglednica 13), da je njihova organizacija procesno usmerjena (povprečna vrednost $=4,73$ ) ter da je uspešno in učinkovito upravljanje poslovnih procesov njihova prednost (povprečna vrednost $=4,45$ ). 
Uspešno in učinkovito upravljanje poslovnih procesov je naša prednost.

V nadaljevanju smo procesno usmerjenost razdelili na devet elementov, in sicer: I) strateški vidik, 2) opremljenost in dokumentiranje procesov, 3) merjenje in management procesov, 4) procesno organizacijsko strukturo, 5) upravljanje z zaposlenimi, 6) procesno organizacijsko kulturo, 7) tržno usmerjenost, 8) vidik dobaviteljev (poslovnih partnerjev) in 9) procesno in informacijsko tehnologijo. Za vsak element procesne usmerjenosti smo izvedli opisno statistiko (izračun frekvenc, srednjih vrednosti in standardnega odklona). Za namene preverjanja zastavljenih hipotez smo v nadaljevanju za vsak element procesne usmerjenosti z metodo glavnih komponent določili faktorje/glavne komponente, ki pojasnijo čim večji delež celotne variance (priloga 2).

\section{Strateški vidik}

\section{Osnovna statistična analiza - strateški vidik}

Anketirani se v povprečju najbolj strinjajo s trditvijo, da cilji poslovnih procesov izhajajo iz strateških ciljev organizacije (povprečna vrednost $=$ $5,29)$, najmanj pa s trditvijo, da so zaposleni na vseh nivojih dobro seznanjeni $s$ strateškimi cilji (povprečna vrednost $=4,20$ ). Ostali podatki so razvidni iz preglednice 14 .

Preglednica I4: Strateški vidik

\begin{tabular}{|c|c|c|c|}
\hline Spremenljivka & $\mathbf{N}$ & $\begin{array}{l}\text { Povprečna } \\
\text { vrednost }\end{array}$ & $\begin{array}{l}\text { Standardni } \\
\text { odklon }\end{array}$ \\
\hline Cilji poslovnih procesov izhajajo iz strateških ciljev organizacije. & 233 & 5,29 & $\mathrm{I}, 48$ \\
\hline $\begin{array}{l}\text { Vodstvo organizacije je aktivno vključeno v izboljševanje in prenove poslovnih } \\
\text { procesov. }\end{array}$ & 231 & 5,23 & I,6I \\
\hline $\begin{array}{l}\text { Na kolegijih na vseh nivojih vodenja se pogosto pogovarjamo o izboljševanju in } \\
\text { prenovah poslovnih procesov. }\end{array}$ & 210 & 4,73 & 1,51 \\
\hline $\begin{array}{l}\text { Načrti za izboljšave glavnih procesov obstajajo ter so narejeni na podlagi izpoln- } \\
\text { jevanja pričakovanj odjemalcev, drugih relevantnih deležnikov in strategije. }\end{array}$ & 212 & 4,69 & $\mathrm{I}, 48$ \\
\hline Zaposleni na vseh nivojih so dobro seznanjeni s strateškimi cilji. & 234 & 4,20 & $\mathrm{I}, 45$ \\
\hline
\end{tabular}


Faktorska analiza - strateški vidik

Faktorska analiza je pokazala, da so podatki primerni za analizo (KMO $=0,87 \mathrm{I}$; Bartlettov test $\mathrm{sig}=0,000)-$ preglednica is .

Preglednica I s: KMO in Bartlettov test - strateški vidik

\begin{tabular}{lcc} 
& Kaiser-Meyer-Olkin - KMO & 0,871 \\
\hline \multirow{2}{*}{ Bartlettov Test } & Hi-kvadrat & 671,635 \\
\cline { 2 - 3 } & sig & 10 \\
\hline
\end{tabular}

Glede na to, da so bile vse komunalitete posameznih spremenljivk višje od o,400, smo obdržali vse spremenljivke. V preglednici 16 je prikazana nova komponenta, ki pojasni 75,16 \% celotne variance.

Preglednica ı 6: Celotna pojasnjena varianca - strateški vidik

\begin{tabular}{ccccccc} 
& \multicolumn{2}{c}{ Začetne lastne vrednosti } & \multicolumn{2}{c}{ Ekstrakcijski seštevki kvadratov uteži } \\
\hline Faktor & Skupaj & $\begin{array}{c}\text { Delež } \\
\text { variance v } \%\end{array}$ & Kumulativa v \% & Skupaj & $\begin{array}{c}\text { Delež } \\
\text { variance v \% }\end{array}$ & Kumulativav \% \\
\hline 1 & 3,758 & 75,158 & 75,158 & 3,758 & 75,158 & 75,158 \\
\hline 2 & 0,466 & 9,311 & 84,469 & & \\
\hline 3 & 0,330 & 6,595 & 91,064 & & \\
\hline 4 & 0,264 & 5,290 & 96,354 & & \\
\hline 5 & 0,182 & 3,646 & 100,000 & & \\
\hline
\end{tabular}

Novo spremenljivko smo imenovali »Strateški vidik«. Uteži posameznih spremenljivk, vključenih $\mathrm{v}$ novo spremenljivko, so razvidne iz preglednice 17 . 
Preglednica 17: Uteži posameznih spremenljivk, vključenih v novo spremenljivko »Strateški vidik

\begin{tabular}{llc} 
& \multicolumn{1}{c}{ Spremenljivka } & Utež \\
Qıa & $\begin{array}{l}\text { Načrti za izboljšave glavnih procesov obstajajo ter so narejeni na podlagi izpolnjevanja pričako- } \\
\text { vanjodjemalcev, drugih relevantnih deležnikov in strategije. }\end{array}$ & 0,89 I \\
\hline Qıb & Vodstvo organizacije je aktivno vključeno v izboljševanje in prenove poslovnih procesov. & 0,890 \\
\hline Qıc & Cilji poslovnih procesov izhajajo iz strateških ciljev organizacije. & 0,878 \\
\hline Qıd & $\begin{array}{l}\text { Na kolegijih na vseh nivojih vodenja se pogosto pogovarjamo o izboljševanju in prenovah } \\
\text { poslovnih procesov. }\end{array}$ & 0,863 \\
\hline Qıe & Zaposleni na vseh nivojih so dobro seznanjeni s strateškimi cilji. & 0,810 \\
\hline
\end{tabular}

Za novo spremenljivko »Strateški vidik« smo izračunali povprečno vrednost in standardni odklon - preglednica 18.

Preglednica I 8: Povprečna vrednost in standardni odklon nove spremenljivke » Strateški vi$\operatorname{dik}_{\kappa}$

\section{Opredeljenost in dokumentiranje procesov}

\section{Osnovna statistična analiza - opredeljenost in dokumentiranje procesov}

Anketirani se v povprečju strinjajo, da so v njihovi organizaciji definirani glavni in podporni poslovni procesi - preglednica 19.

Preglednica 19: Glavni in podporni poslovni procesi

\begin{tabular}{cccc} 
Spremenljivka & N & $\begin{array}{c}\text { Povprečna } \\
\text { vrednost }\end{array}$ & $\begin{array}{c}\text { Standardni } \\
\text { odklon }\end{array}$ \\
\hline V naši organizaciji so definirani glavni in podporni poslovni procesi. & 228 & 5,73 & $\mathrm{I}, 524$ \\
\hline
\end{tabular}

Največ anketiranih (43 oziroma $20 \%$ ) meni, da je v organizaciji 5 glavnih procesov. Da je glavnih procesov med I in 8, meni kar 186 anketiranih oziroma $86,5 \%$. Preostali anketirani menijo, da je glavnih procesov ro ali več.

Podobno tudi glede števila podpornih procesov največji delež anketiranih meni, da jih je 5 . Vendar je tu delež nižji kot pri glavnih procesih (34 oziroma $16,4 \%$ ). Da je podpornih procesov med $\mathrm{I}$ in 8 , meni 130 an- 
ketiranih oziroma $62,8 \% .77$ anketiranih oziroma 37,2 \% meni, da je število podpornih procesov večje ali enako ı.

Anketirani se v povprečju najbolj strinjajo s trditvijo, da so opisi (modeli) poslovnih procesov dostopni vsem zaposlenim (povprečna vrednost $=5,79$ ), najmanj pa s trditvijo, da so poslovni procesi definirani tako, da večina zaposlenih razume, kako potekajo (povprečna vrednost $=4,53$ ). Ostali podatki so razvidni iz preglednice 20.

Preglednica 20: Opredeljenost in dokumentiranje procesov

\begin{tabular}{lccc}
\multicolumn{1}{c}{ Spremenljivka } & N & $\begin{array}{c}\text { Povprečna } \\
\text { vrednost }\end{array}$ & $\begin{array}{c}\text { Standardni } \\
\text { odklon }\end{array}$ \\
\hline Opisi (modeli) poslovnih procesov so dostopni vsem zaposlenim. & 231 & 5,79 & $\mathrm{I}, 44$ \\
\hline Procesi so dokumentirani z jasno opredeljenimi vhodi in izhodi. & 229 & 5,27 & $\mathrm{I}, 42$ \\
\hline Uporabljamo uveljavljene sodobne metode za opisovanje poslovnih procesov. & 205 & 5,22 & $\mathrm{I}, 40$ \\
\hline $\begin{array}{l}\text { Naloge in odgovornosti zaposlenih pri izvajanju procesov so jasno definirane in } \\
\text { dokumentirane. }\end{array}$ & 231 & 5,11 & $\mathrm{1}, 39$ \\
\hline \begin{tabular}{l} 
Poslovni procesi so definirani tako, da večina zaposlenih razume, kako potekajo. \\
\hline
\end{tabular} & 232 & 4,53 & $\mathrm{I}, 56$ \\
\hline
\end{tabular}

Faktorska analiza - opredeljenost in dokumentiranje procesov

Faktorska analiza je pokazala, da so podatki primerni za analizo (KMO $=0,847$; Bartlettov test sig $=0,000)-$ preglednica $2 \mathrm{I}$.

Preglednica 21: KMO in Bartlettov test - opredeljenost in dokumentiranje procesov

\begin{tabular}{lcc} 
& Kaiser-Meyer-Olkin - KMO & 0,847 \\
\hline \multirow{2}{*}{ Bartlettov Test } & Hi-kvadrat & 661,519 \\
\hline df & 10 \\
\hline
\end{tabular}

Glede na to, da so bile vse komunalitete posameznih spremenljivk višje od 0,400 , smo obdržali vse spremenljivke. V preglednici 22 je prikazana nova komponenta, ki pojasni 72,57 \% celotne variance. 
Merjenje zrelosti procesne usmerjenosti

Preglednica 22: Celotna pojasnjena varianca - opredeljenost in dokumentiranje procesov

\begin{tabular}{ccccccc} 
& \multicolumn{3}{c}{ Začetne lastne vrednosti } & \multicolumn{2}{c}{ Ekstrakcijski seštevki kvadratov uteži } \\
\hline Faktor & Skupaj & $\begin{array}{c}\text { Delež } \\
\text { variance v \% }\end{array}$ & Kumulativa v \% & Skupaj & $\begin{array}{c}\text { Delež } \\
\text { variance v \% }\end{array}$ & Kumulativa v \% \\
\hline I & 3,629 & 72,572 & 72,572 & 3,629 & 72,572 & 72,572 \\
\hline 2 & 0,562 & 11,238 & 83,810 & & \\
\hline 3 & 0,344 & 6,876 & 90,686 & & \\
\hline 4 & 0,319 & 6,388 & 97,074 & & \\
\hline 5 & 0,146 & 2,926 & 100,000 & & \\
\hline
\end{tabular}

Novo spremenljivko smo imenovali $\gg$ Opredeljenost in dokumentiranje procesov«. Uteži posameznih spremenljivk, vključenih v novo spremenljivko, so razvidne iz preglednice 23.

Preglednica 23: Uteži posameznih spremenljivk, vključenih v novo spremenljivko »Opredeljenost in dokumentiranje procesov $\ll$

\begin{tabular}{|c|c|c|}
\hline & Spremenljivka & Utež \\
\hline Qja & Naloge in odgovornosti zaposlenih pri izvajanju procesov so jasno definirane in dokumentirane. & 0,912 \\
\hline$Q_{5} b$ & Procesi so dokumentirani z jasno opredeljenimi vhodi in izhodi. & 0,882 \\
\hline $\mathrm{Q}_{5} \mathrm{C}$ & Poslovni procesi so definirani tako, da večina zaposlenih razume, kako potekajo. & 0,856 \\
\hline $\mathrm{Q}_{5} \mathrm{~d}$ & Uporabljamo uveljavljene sodobne metode za opisovanje poslovnih procesov. & 0,840 \\
\hline Q5e & Opisi (modeli) poslovnih procesov so dostopni vsem zaposlenim. & 0,761 \\
\hline
\end{tabular}

Za novo spremenljivko »Opredeljenost in dokumentiranje procesov « smo izračunali povprečno vrednost in standardni odklon - preglednica 24.

Preglednica 24: Povprečna vrednost in standardni odklon nove spremenljivke »Opredeljenost in dokumentiranje procesov $\ll$ 


\section{Merjenje in management procesov}

\section{Osnovna statistična analiza}

Anketirani se v povprečju najbolj strinjajo s trditvijo, da so kazalniki procesov definirani in dokumentirani (povprečna vrednost $=5,22$ ), najmanj pa s trditvijo, da so o rezultatih kazalnikov in doseganju ciljnih vrednosti zaposleni redno obveščeni (povprečna vrednost $=4,28$ ). Ostali podatki so razvidni iz preglednice 25 .

Preglednica 25: Merjenje in management procesov

\begin{tabular}{lccc}
\multicolumn{1}{c}{ Spremenljivka } & N & $\begin{array}{c}\text { Povprečna } \\
\text { vrednost }\end{array}$ & $\begin{array}{c}\text { Standardni } \\
\text { odklon }\end{array}$ \\
\hline Kazalniki procesov so definirani in dokumentirani. & 228 & 5,22 & 1,49 \\
\hline V organizaciji merimo uspešnost in učinkovitost poslovnih procesov. & 232 & 5,14 & 1,59 \\
\hline Postavljeni so konkretni cilji za posamezne kazalnike procesa. & 230 & 5,03 & 1,56 \\
\hline Procese izbolǰ̌ujemo skozi formalne postopke. & 226 & 4,98 & 1,50 \\
\hline Zaposleni so seznanjeni s spremembami v procesih. & 233 & 4,82 & 1,59 \\
\hline Rezultati merjenj služijo za postavljanje ciljev za izboljšave procesov. & 227 & 4,69 & 1,61 \\
\hline Orezultatih kazalnikov in doseganju ciljnih vrednosti so zaposleni redno ob- & 232 & 4,28 & 1,70 \\
veščeni. & & & \\
\hline
\end{tabular}

\section{Faktorska analiza - merjenje in management procesov}

Faktorska analiza je pokazala, da so podatki primerni za analizo (KMO $=0,875 ;$ Bartlettov test $\operatorname{sig}=0,000)-$ preglednica 26 .

Preglednica 26: KMO in Bartlettov test merjenje in management procesov

Kaiser-Meyer-Olkin - KMO

\begin{tabular}{|c|c|c|}
\hline \multirow{3}{*}{ Bartlettov Test } & Hi-kvadrat & 1264,505 \\
\hline & $\mathrm{df}$ & $2 \mathrm{I}$ \\
\hline & sig & ০,০০০ \\
\hline
\end{tabular}

Glede na to, da so bile vse komunalitete posameznih spremenljivk višje od 0,400 , smo obdržali vse spremenljivke. V preglednici 27 je prikazana nova komponenta, ki pojasni 71,38 \% celotne variance. 
Merjenje zrelosti procesne usmerjenosti

Preglednica 27: Celotna pojasnjena varianca - merjenje in management procesov

\begin{tabular}{|c|c|c|c|c|c|c|}
\hline \multicolumn{4}{|c|}{ Začetne lastne vrednosti } & \multicolumn{3}{|c|}{ Ekstrakcijski seštevki kvadratov uteži } \\
\hline Faktor & Skupaj & $\begin{array}{c}\text { Delež } \\
\text { variance v \% }\end{array}$ & Kumulativa v \% & Skupaj & $\begin{array}{c}\text { Delež } \\
\text { variance v } \%\end{array}$ & Kumulativa v \% \\
\hline
\end{tabular}

\begin{tabular}{ccccccc}
$\mathrm{I}$ & 4,996 & $7 \mathrm{I}, 378$ & $7 \mathrm{1}, 378$ & 4,996 & 71,378 & $7 \mathrm{1}, 378$ \\
\hline 2 & 0,736 & 10,516 & 81,894 & & \\
\hline 3 & 0,416 & 5,944 & 87,838 & &
\end{tabular}

\begin{tabular}{llll}
\hline 4 & 0,337 & 4,817 & 92,655 \\
\hline 5 & 0,209 & 2,992 & 95,647 \\
\hline 6 & 0,167 & 2,390 & 98,036 \\
\hline 7 & 0,137 & 1,964 & 100,000 \\
\hline
\end{tabular}

Novo spremenljivko smo imenovali »Merjenje in management procesov«. Uteži posameznih spremenljivk, vključenih v novo spremenljivko, so razvidne iz preglednice 28 .

Preglednica 28: Uteži posameznih spremenljivk, vključenih v novo spremenljivko »Merjenje in management procesov«

\begin{tabular}{llc} 
Q6a & Postavljeni so konkretni cilji za posamezne kazalnike procesa. & 0,903 \\
\hline Q6b & Rezultati merjenj služijo za postavljanje ciljev za izboljšave procesov. & 0,894 \\
\hline Q6c & Kazalniki procesov so definirani in dokumentirani. & 0,890 \\
\hline Q6d & V organizaciji merimo uspešnost in učinkovitost poslovnih procesov. & 0,875 \\
\hline Q6e & O rezultatih kazalnikov in doseganju ciljnih vrednosti so zaposleni redno obveščeni. & 0,848 \\
\hline Q6f & Procese izboljšujemo skozi formalne postopke. & 0,807 \\
\hline Q6g & Zaposleni so seznanjeni s spremembami v procesih. & 0,675
\end{tabular}

Za novo spremenljivko »Merjenje in management procesov « smo izračunali povprečno vrednost in standardni odklon - preglednica 29. 
Preglednica 29: Povprečna vrednost in standardni odklon nove spremenljivke »Merjenje in management procesov $\ll$

\section{Procesna organizacijska struktura}

\section{Osnovna statistična analiza - procesna organizacijska struktura}

Anketirani se v povprečju najbolj strinjajo s trditvijo, da delovna mesta zahtevajo opravljanje širokega spektra različnih nalog (večopravilnost) (povprečna vrednost $=5,85$ ), najmanj pa s trditvijo, da so direktorji poslovnih funkcij v vodstveni hierarhiji pozicionirani višje od lastnikov procesov (povprečna vrednost $=2,73$ ). Ostali podatki so razvidni iz preglednice 30.

Preglednica 30: Procesna organizacijska struktura

\begin{tabular}{lccc}
\multicolumn{1}{c|}{ Spremenljivka } & N & $\begin{array}{c}\text { Povprečna } \\
\text { vrednost }\end{array}$ & $\begin{array}{c}\text { Standardni } \\
\text { odklon }\end{array}$ \\
$\begin{array}{l}\text { Delovna mesta zahtevajo opravljanje širokega spektra različnih nalog } \\
\text { (večopravilnost). }\end{array}$ & 239 & 5,85 & 1,23 \\
\hline $\begin{array}{l}\text { Zaposleni pogosto delajo v skupinah, ki jih sestavljajo predstavniki ra- } \\
\text { zličnih organizacijskih enot. }\end{array}$ & 238 & 5,10 & 1,50 \\
\hline Vzpostavljeno je nedvoumno lastništvo poslovnih procesov. & 232 & 5,07 & 1,64 \\
\hline $\begin{array}{l}\text { Organizacijska struktura podpira nemoteno izvajanje procesov skozi } \\
\text { poslovne funkcije (področja, sektorje, službe, oddelke). }\end{array}$ & 236 & 4,75 & 1,53 \\
\hline $\begin{array}{l}\text { Direktorji poslovnih funkcij so v vodstveni hierarhiji pozicionirani višje od } \\
\text { lastnikov procesov. }\end{array}$ & 206 & 2,73 & 1,77 \\
\hline
\end{tabular}

Na vprašanje, kakšen je položaj najvišje rangiranega zaposlenega, odgovornega za procese, je največ anketiranih (39,2 \%) odgovorilo, da je najvišji rangirani zaposleni neposredno podrejen najvišjemu vodstvu - slika 33. 


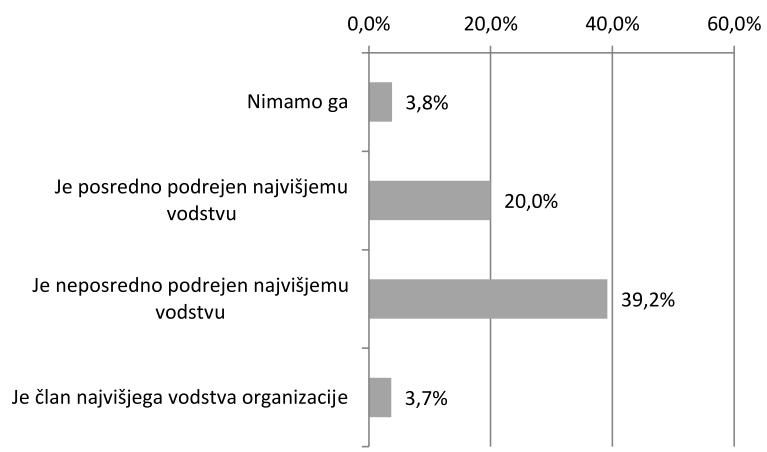

Slika 33: Položaj najvišje rangiranega zaposlenega, odgovornega za procese

$70,8 \%$ anketiranih meni, da imajo v organizaciji posebno organizacijsko enoto ali del organizacijske enote, ki lastnikom procesov zagotavlja strokovno podporo pri dokumentiranju, spremljanju kazalnikov in izboljševanju procesov, $29,2 \%$ anketiranih pa meni, da za te namene posebne organizacijske enote nimajo.

\section{Faktorska analiza - procesna organizacijska struktura}

Faktorska analiza je pokazala, da so podatki primerni za analizo (KMO $=0,7 \mathrm{I} 4$; Bartlettov test sig $=0,000)-$ preglednica $3 \mathrm{I}$.

Preglednica 31: KMO in Bartlettov test procesna organizacijska struktura

\begin{tabular}{lc} 
Bi-kvadrat & 190,204 \\
\cline { 2 - 2 } Bartlettov Test & 10 \\
\hline sig & 0,000
\end{tabular}

Glede na to, da so bile vse komunalitete posameznih spremenljivk višje od 0,400 , smo obdržali vse spremenljivke. V preglednici 23 sta prikazani dve novi komponenti, ki skupaj pojasnita 67,07 \% celotne variance. 
Preglednica 32: Celotna pojasnjena varianca - procesna organizacijska struktura

\begin{tabular}{ccccccc} 
& \multicolumn{3}{c}{ Začetne lastne vrednosti } & \multicolumn{2}{c}{ Ekstrakcijski seštevki kvadratov uteži } \\
\hline Faktor & Skupaj & $\begin{array}{c}\text { Delež } \\
\text { variance v } \%\end{array}$ & $\begin{array}{c}\text { Kumulati- } \\
\text { va v \% }\end{array}$ & Skupaj & $\begin{array}{c}\text { Delež } \\
\text { variance v \% }\end{array}$ & $\begin{array}{c}\text { Kumulati- } \\
\text { va v \% }\end{array}$ \\
\hline I & 2,155 & 43,097 & 43,097 & 1,819 & 36,388 & 36,388 \\
\hline 2 & 1,199 & 23,976 & 67,074 & 1,534 & 30,686 & 67,074 \\
\hline 3 & 0,724 & 14,478 & 81,551 & & & \\
\hline 4 & 0,548 & 10,968 & 92,519 & & & \\
\hline 5 & 0,374 & $7,48 \mathrm{I}$ & 100,000 & & & \\
\hline
\end{tabular}

Prva komponenta procesne organizacijske strukture $\left(\mathrm{POS}_{\mathrm{I}}\right)$ vsebuje dve spremenljivki in pojasni $36,39 \%$ celotne variance. Druga komponenta procesne organizacijske strukture $\left(\mathrm{POS}_{2}\right)$ vsebuje tri spremenljivke in pojasni $30,69 \%$ celotne variance. Uteži posameznih spremenljivk, vključenih v novi spremenljivki $\mathrm{POS}_{1}$ in $\mathrm{POS}_{2}$, so razvidne iz preglednice 33.

Preglednica 33: Uteži posameznih spremenljivk, vključenih v novi spremenljivki procesne organizacijske strukture

\begin{tabular}{|c|c|c|c|}
\hline & Spremenljivka & $\begin{array}{l}\text { Utež } \\
\text { POS I }\end{array}$ & $\begin{array}{c}\text { Utež } \\
\text { POS }_{2}\end{array}$ \\
\hline Q7za & Vzpostavljeno je nedvoumno lastništvo poslovnih procesov. & 0,890 & \\
\hline $\mathrm{Q}_{7} \mathrm{~b}$ & $\begin{array}{l}\text { Organizacijska struktura podpira nemoteno izvajanje procesov skozi poslovne funkci- } \\
\text { je (področja, sektorje, službe, oddelke). }\end{array}$ & 0,868 & \\
\hline$Q_{7 Z c}$ & Delovna mesta zahtevajo opravljanje širokega spektra različnih nalog (večopravilnost). & & $0,8 \mathrm{I} 3$ \\
\hline$Q_{7} \mathrm{~d}$ & $\begin{array}{l}\text { Direktorji poslovnih funkcij so v vodstveni hierarhiji pozicionirani višje od lastnikov } \\
\text { procesov. }\end{array}$ & & 0,749 \\
\hline Q7e & $\begin{array}{l}\text { Zaposleni pogosto delajo v skupinah, ki jih sestavljajo predstavniki različnih organi- } \\
\text { zacijskih enot. }\end{array}$ & & $0,55 \mathrm{I}$ \\
\hline
\end{tabular}

Novo spremenljivko »Procesna organizacijska struktura « smo dobili $\mathrm{z}$ metodo tehtanega povprečja, kot prikazuje naslednja enačba:

Procesna organizacijsk a struktura $=\left(\left(P O S_{I}{ }^{*}{ }_{I} .8 I g\right)+\left(P_{1} O S_{2} *\right.\right.$ I.534)) / (I.819 + I.534)

Za novo spremenljivko $\gg$ Procesna organizacijska struktura $\ll$ smo izračunali povprečno vrednost in standardni odklon - preglednica 3. 
Preglednica 34: Povprečna vrednost in standardni odklon nove spremenljivke »Procesna organizacijska struktura

\section{Upravljanje z zaposlenimi}

\section{Osnovna statistična analiza - upravljanje z zaposlenimi}

Anketirani se v povprečju najbolj strinjajo $s$ trditvijo, da se zaposleni neprestano učijo (povprečna vrednost $=5,16$ ), najmanj pa s trditvijo, da so zaposleni stimulirani za predloge izboljšav procesov (povprečna vrednost $=3,25$ ). Ostali podatki so razvidni iz preglednice 35 .

Preglednica 35: Upravljanje z zaposlenimi

\begin{tabular}{lccc}
\multicolumn{1}{c}{ Spremenljivka } & N & $\begin{array}{c}\text { Povprečna } \\
\text { vrednost }\end{array}$ & $\begin{array}{c}\text { Standardni } \\
\text { odklon }\end{array}$ \\
Zaposleni se neprestano učijo. & 238 & 5,16 & 1,46 \\
\hline Zaposleni so odgovorni za doseganje ciljev poslovnih procesov. & 238 & 5,11 & 1,49 \\
\hline $\begin{array}{l}\text { Pred uvedbo spremenjenega načina izvajanja poslovnih procesov zaposlene } \\
\text { dobro seznanimo s spremembami. }\end{array}$ & 236 & 4,33 & 1,54 \\
\hline Zaposleni poznajo metode in tehnike izboljševanja poslovnih procesov. & 236 & 4,22 & 1,42 \\
\hline Zaposleni so stimulirani za predloge izboljšav procesov. & 233 & 3,25 & 1,73 \\
\hline
\end{tabular}

\section{Faktorska analiza - upravljanje zzaposlenimi}

Faktorska analiza je pokazala, da so podatki primerni za analizo (KMO $=0,795 ;$ Bartlettov test sig $=0,000)-$ preglednica 36 .

Preglednica 36: KMO in Bartlettov test upravljanje z zaposlenimi

\begin{tabular}{lcc} 
& Kaiser-Meyer-Olkin - KMO & 0,795 \\
\hline \multirow{2}{*}{ Bartlettov Test } & Hi-kvadrat & 416,003 \\
\hline sig & 10 \\
\hline
\end{tabular}

Glede na to, da so bile vse komunalitete posameznih spremenljivk višje od o,400, smo obdržali vse spremenljivke. V preglednici 37 je prikazana nova komponenta, ki pojasni $58,66 \%$ celotne variance. 
Preglednica 37: Celotna pojasnjena varianca - upravljanje z zaposlenimi

\begin{tabular}{ccccccc}
\multicolumn{3}{c}{ Začetne lastne vrednosti } & \multicolumn{3}{c}{ Ekstrakcijski seštevki kvadratov uteži } \\
\hline Faktor & Skupaj & $\begin{array}{c}\text { Delež } \\
\text { variance v } \%\end{array}$ & Kumulativa v \% & Skupaj & $\begin{array}{c}\text { Delež } \\
\text { variance v \% }\end{array}$ & Kumulativa v \% \\
\hline I & 2,933 & 58,656 & 58,656 & 2,933 & 58,656 & 58,656 \\
\hline 2 & 0,724 & 14,480 & 73,135 & & \\
\hline 3 & 0,627 & 12,547 & 85,682 & & \\
\hline 4 & 0,474 & 9,470 & 95,152 & & \\
\hline 5 & 0,242 & 4,848 & 100,000 & & \\
\hline
\end{tabular}

Novo spremenljivko smo imenovali »Upravljanje z zaposlenimi«. Uteži posameznih spremenljivk, vključenih v novo spremenljivko, so razvidne iz preglednice 38 .

Preglednica 38: Uteži posameznih spremenljivk, vključenih v novo spremenljivko »Upravljanje z zaposlenimi

\begin{tabular}{llc} 
& \multicolumn{1}{c}{ Spremenljivka } & Utež \\
\hline Qıoa & Zaposleni poznajo metode in tehnike izboljševanja poslovnih procesov. & 0,895 \\
\hline Qıob & $\begin{array}{l}\text { Pred uvedbo spremenjenega načina izvajanja poslovnih procesov zaposlene dobro seznanimo } \\
\text { s spremembami. }\end{array}$ & 0,817 \\
\hline Qıoc & Zaposleni se neprestano učijo. & 0,745 \\
\hline Qıod & Zaposleni so odgovorni za doseganje ciljev poslovnih procesov. & 0,675 \\
\hline Qıoe & Zaposleni so stimulirani za predloge izboljšav procesov. & 0,673 \\
\hline
\end{tabular}

Za novo spremenljivko »Upravljanje z zaposlenimi« smo izračunali povprečno vrednost in standardni odklon - preglednica 39.

Preglednica 39: Povprečna vrednost in standardni odklon nove spremenljivke »Upravljanje zzaposlenimi 


\section{Procesna organizacijska kultura}

\section{Osnovna statistična analiza - procesna organizacijska kultura}

Anketirani se v povprečju najbolj strinjajo s trditvijo, da se zaposleni iz različnih organizacijskih enot med seboj posvetujejo, kadar je to potrebno (povprečna vrednost $=5,16$ ), najmanj pa s trditvijo, da imajo zaposleni iz različnih organizacijskih enot občutek, da so njihovi cilji med seboj usklajeni (povprečna vrednost $=3,99$ ). Ostali podatki so razvidni iz preglednice 40 .

\section{Preglednica 40: Procesna organizacijska kultura}

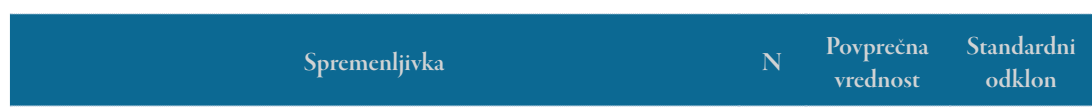

\begin{tabular}{lccc}
$\begin{array}{l}\text { Zaposleni iz različnih organizacijskih enot se med seboj posvetujejo, kadar je } \\
\text { to potrebno. }\end{array}$ & 234,16 & 1,37 \\
\hline $\begin{array}{l}\text { V organizaciji se pogosto uporabljajo izrazi, kot so proces, vhod procesa, } \\
\text { izhod (rezultat) procesa, lastnik oz. skrbnik procesa, kazalniki procesa, cil- } \\
\text { ji procesa. }\end{array}$ & 239 & 4,89 & 1,63 \\
\hline $\begin{array}{l}\text { Vodje različnih organizacijskih enot se pogosto sestajajo zaradi usklajevanja } \\
\text { aktivnosti med organizacijskimi enotami. }\end{array}$ & 219 & 4,58 & $\mathrm{I}, 55$ \\
\hline $\begin{array}{l}\text { Ko se srečajo zaposleni iz različnih organizacijskih enot, je pogosto prisotna } \\
\text { napetost pri komunikaciji. }\end{array}$ & 236 & 4,30 & $\mathrm{I}, 61$ \\
\hline $\begin{array}{l}\text { Povprečni zaposleni razume delovanje organizacije kot niz povezanih pro- } \\
\text { cesov. }\end{array}$ & 238 & 4,13 & $\mathrm{I}, 46$ \\
\hline $\begin{array}{l}\text { Zaposleni iz različnih organizacijskih enot imajo občutek, da so njihovi cil- } \\
\text { ji med seboj usklajeni. }\end{array}$ & 234 & 3,99 & $\mathrm{I}, 43$
\end{tabular}

\section{Faktorska analiza - procesna organizacijska kultura}

Prvi poskus faktorske analize je pokazal, da so podatki primerni za analizo $(\mathrm{KMO}=0,791$; Bartlettov test sig $=0,000)$. Ker je imela spremenljivka »Ko se srečajo zaposleni iz različnih organizacijskih enot, je pogosto prisotna napetost pri komunikaciji k komunaliteto manjšo od 0,400 , smo jo iz nadaljnje analize izključili. Ponovni poskus faktorske analize je prav tako pokazal, da so podatki primerni za analizo $(\mathrm{KMO}=0,8 \circ \mathrm{I}$; Bartlettov test sig $=0,000)-$ preglednica 4I. 


\begin{tabular}{lc} 
Hi-kvadrat & 373,863 \\
\hline $\mathrm{df}$ & 10 \\
\hline sig & 0,000
\end{tabular}

Glede na to, da so bile vse komunalitete posameznih spremenljivk višje od 0,400 , smo obdržali vse spremenljivke. V preglednici 42 je prikazana nova komponenta, ki pojasni $58,54 \%$ celotne variance.

Preglednica 42: Celotna pojasnjena varianca - procesna organizacijska kultura

\begin{tabular}{|c|c|c|c|c|c|c|}
\hline \multicolumn{4}{|c|}{ Začetne lastne vrednosti } & \multicolumn{3}{|c|}{ Ekstrakcijski seštevki kvadratov uteži } \\
\hline Faktor & Skupaj & $\begin{array}{c}\text { Delež } \\
\text { variance v \% }\end{array}$ & Kumulativa v \% & Skupaj & $\begin{array}{c}\text { Delež } \\
\text { variance v \% }\end{array}$ & Kumulativa v \% \\
\hline I & 2,927 & 58,536 & 58,536 & 2,927 & 58,536 & 58,536 \\
\hline 2 & 0,788 & 15,769 & 74,305 & & & \\
\hline 3 & 0,543 & 10,852 & 85,157 & & & \\
\hline 4 & 0,378 & 7,568 & 92,725 & & & \\
\hline 5 & 0,364 & 7,275 & 100,000 & & & \\
\hline
\end{tabular}

Novo spremenljivko smo imenovali »Procesna organizacijska kultura«. Uteži posameznih spremenljivk, vključenih v novo spremenljivko, so razvidne iz preglednice 43.

Preglednica 43: Uteži posameznih spremenljivk, vključenih v novo spremenljivko $\gg$ Procesna organizacijska kultura

Qira Zaposleni iz različnih organizacijskih enot se med seboj posvetujejo, kadar je to potrebno. $0,8 \circ 7$

QıIb Zaposleni iz različnih organizacijskih enot imajo občutek, da so njihovi cilji med seboj usklajeni. ,803

QIIC Vodje različnih organizacijskih enot se pogosto sestajajo zaradi usklajevanja aktivnosti med organizacijskimi enotami.

QiIe Povprečni zaposleni razume delovanje organizacije kot niz povezanih procesov.

QIff V organizaciji se pogosto uporabljajo izrazi, kot so proces, vhod procesa, izhod (rezultat) procesa, lastnik oz. skrbnik procesa, kazalniki procesa, cilji procesa. 
Za novo spremenljivko $\gg$ Procesna organizacijska kultura $\ll$ smo izračunali povprečno vrednost in standardni odklon - preglednica 44 .

Preglednica 44: Povprečna vrednost in standardni odklon nove spremenljivke »Procesna organizacijska kultura«

\section{Tržna usmerjenost}

\section{Osnovna statistična analiza - tržna usmerjenost}

Anketirani se v povprečju najbolj strinjajo s trditvijo, da se v organizaciji na spremembe zahtev trga z električno energijo hitro odzovejo (povprečna vrednost $=4,76$ ), najmanj pa s trditvijo, da zadovoljstvo odjemalcev v organizaciji merijo redno in sistematično (povprečna vrednost $=4,27$ ). Ostali podatki so razvidni iz preglednice 45 .

\section{Preglednica 45: Tržna usmerjenost}

\begin{tabular}{|c|c|c|c|}
\hline Spremenljivka & $\mathbf{N}$ & $\begin{array}{l}\text { Povprečna } \\
\text { vrednost }\end{array}$ & $\begin{array}{l}\text { Standardni } \\
\text { odklon }\end{array}$ \\
\hline Na spremembe zahtev trga z električno energijo se hitro odzovemo. & 206 & 4,76 & 1,57 \\
\hline Zaposleni dobro razumejo potrebe in želje odjemalcev. & 222 & 4,68 & 1,52 \\
\hline Odzive odjemalcev spremljamo in uporabljamo pri izboljševanju procesov. & 216 & 4,62 & 1,60 \\
\hline Storitve organizacije so osnovane na podlagi potreb in pričakovanj odjemalcev. & 220 & 4,6 I & I,6I \\
\hline Spremljamo delovanje podobnih organizacij doma in v tujini. & 207 & 4,57 & 1,64 \\
\hline $\begin{array}{l}\text { Potrebe odjemalcev (oz. kupcev, uporabnikov) sistematično spremljamo in an- } \\
\text { aliziramo. }\end{array}$ & 211 & 4,56 & $\mathrm{I}, 6 \mathrm{I}$ \\
\hline Zadovoljstvo odjemalcev merimo redno in sistematično. & 204 & 4,27 & 1,68 \\
\hline
\end{tabular}

\section{Faktorska analiza - tržna usmerjenost}

Faktorska analiza je pokazala, da so podatki primerni za analizo (KMO $=0,882$; Bartlettov test sig $=0,000)-$ preglednica 46 . 
Bartlettov Test

\begin{tabular}{cc}
$\mathrm{df}$ & 21 \\
\hline sig & 0,000
\end{tabular}

Glede na to, da so bile vse komunalitete posameznih spremenljivk višje od o,400, smo obdržali vse spremenljivke. V preglednici 47 je prikazana nova komponenta, ki pojasni $68,49 \%$ celotne variance.

Preglednica 47: Celotna pojasnjena varianca - tržna usmerjenost

\begin{tabular}{lcccccc} 
& \multicolumn{3}{c}{ Začetne lastne vrednosti } & \multicolumn{2}{c}{ Ekstrakcijski seštevki kvadratov uteži } \\
\hline Faktor & Skupaj & $\begin{array}{c}\text { Delež } \\
\text { variance v } \%\end{array}$ & Kumulativa v \% & Skupaj & $\begin{array}{c}\text { Delež } \\
\text { variance v \% }\end{array}$ & Kumulativa v \% \\
\hline $\mathrm{I}$ & 4,794 & 68,486 & 68,486 & 4,794 & 68,486 & 68,486 \\
\hline 2 & 0,918 & 13,120 & 81,606 & & \\
\hline 3 & 0,361 & 5,163 & 86,769 & & \\
\hline 4 & 0,322 & 4,602 & 91,371 & & \\
\hline 5 & 0,275 & 3,929 & 95,300 & & \\
\hline 6 & 0,188 & 2,689 & 97,989 & & \\
\hline 7 & 0,141 & 2,011 & 100,000 & & \\
\hline
\end{tabular}

Novo spremenljivko smo imenovali »Tržna usmerjenost«. Uteži posameznih spremenljivk, vključenih v novo spremenljivko, so razvidne iz preglednice 48 .

Preglednica 48: Uteži posameznih spremenljivk, vključenih v novo spremenljivko »Tržna usmerjenost $\ll$

\begin{tabular}{llc} 
Q12a & Odzive odjemalcev spremljamo in uporabljamo pri izboljševanju procesov. & 0,903 \\
\hline Q12b & Potrebe odjemalcev (oz. kupcev, uporabnikov) sistematično spremljamo in analiziramo. & 0,882 \\
\hline Q12c & Storitve organizacije so osnovane na podlagi potreb in pričakovanj odjemalcev. & 0,874 \\
\hline Q12d & Zadovoljstvo odjemalcev merimo redno in sistematično. & 0,847 \\
\hline Q12e & Zaposleni dobro razumejo potrebe in želje odjemalcev. & 0,825 \\
\hline Q12f & Na spremembe zahtev trga z električno energijo se hitro odzovemo. & 0,744 \\
\hline
\end{tabular}


Za novo spremenljivko »Tržna usmerjenost « smo izračunali povprečno vrednost in standardni odklon - preglednica 49.

Preglednica 49: Povprečna vrednost in standardni odklon nove spremenljivke »Tržna usmerjenost $\ll$

\section{Vidik dobaviteljev (poslounih partnerjev)}

\section{Osnovna statistična analiza - vidik dobaviteljev}

Anketirani se v povprečju najbolj strinjajo s trditvijo, da imajo v organizaciji s ključnimi dobavitelji vzpostavljene dolgoročne pogodbe (povprečna vrednost $=5,00$ ), najmanj pa s trditvijo, da o spremembah procesov $\mathrm{v}$ organizaciji dobavitelje formalno obvestijo (povprečna vrednost $=4,02$ ). Ostali podatki so razvidni iz preglednice so.

Preglednica 5o: Vidik dobaviteljev

\begin{tabular}{lccc} 
Spremenljivka & N & $\begin{array}{c}\text { Povprečna } \\
\text { vrednost }\end{array}$ & $\begin{array}{c}\text { Standardni } \\
\text { odklon }\end{array}$ \\
\hline Vzpostavljene imamo dolgoročne pogodbe s ključnimi dobavitelji. & 201 & 5,00 & I,71 \\
\hline Z dobavitelji tesno sodelujemo in se povezujemo na ravni procesov. & 195 & 4,52 & 1,58 \\
\hline O spremembah naših procesov dobavitelje formalno obvestimo. & 182 & 4,02 & 1,69 \\
\hline
\end{tabular}

\section{Faktorska analiza - vidik dobaviteljev}

Faktorska analiza je pokazala, da so podatki primerni za analizo (KMO $=0,702$; Bartlettov test sig $=0,000)-$ preglednica $5 \mathrm{I}$.

Preglednica 5 I: KMO in Bartlettov test - vidik dobaviteljev

\begin{tabular}{lcc} 
& Kaiser-Meyer-Olkin - KMO & 0,702 \\
\hline Bartlettov Test & Hi-kvadrat & 219,414 \\
\hline df & 3 \\
\hline sig & 0,000 \\
\hline
\end{tabular}


Glede na to, da so bile vse komunalitete posameznih spremenljivk višje od 0,400 , smo obdržali vse spremenljivke. V preglednici 52 je prikazana nova komponenta, ki pojasni 75,65 \% celotne variance.

Preglednica 52: Celotna pojasnjena varianca - vidik dobaviteljev

\begin{tabular}{|c|c|c|c|c|c|c|}
\hline \multicolumn{4}{|c|}{ Začetne lastne vrednosti } & \multicolumn{3}{|c|}{ Ekstrakcijski seštevki kvadratov uteži } \\
\hline Faktor & Skupaj & $\begin{array}{c}\text { Delež } \\
\text { variance v } \%\end{array}$ & Kumulativa v \% & Skupaj & $\begin{array}{c}\text { Delež } \\
\text { variance v } \%\end{array}$ & Kumulativa v \% \\
\hline I & 2,270 & 75,654 & 75,654 & 2,270 & 75,654 & 75,654 \\
\hline 2 & 0,479 & 15,962 & 91,617 & & & \\
\hline 3 & $0,25 \mathrm{I}$ & 8,383 & 100,000 & & & \\
\hline
\end{tabular}

Novo spremenljivko smo imenovali »Vidik dobaviteljev«. Uteži posameznih spremenljivk, vključenih v novo spremenljivko, so razvidne iz preglednice 53 .

Preglednica 53: Uteži posameznih spremenljivk, vključenih v novo spremenljivko »Vidik dobaviteljev«

\begin{tabular}{llc} 
& \multicolumn{1}{c}{ Spremenljivka } & Utež \\
\hline Q13a & Z dobavitelji tesno sodelujemo in se povezujemo na ravni procesov. & 0,916 \\
\hline Q13b & Vzpostavljene imamo dolgoročne pogodbe s ključnimi dobavitelji. & 0,860 \\
\hline Q13C & O spremembah našh procesov dobavitelje formalno obvestimo. & 0,831 \\
\hline
\end{tabular}

Za novo spremenljivko »Vidik dobaviteljev« smo izračunali povprečno vrednost in standardni odklon - preglednica 54.

Preglednica 54: Povprečna vrednost in standardni odklon nove spremenljivke »Vidik dobaviteljev«

\section{Procesna informacijska tehnologija}

\section{Osnovna statistična analiza - procesna informacijska tehnologija}

Anketirani se v povprečju najbolj strinjajo s trditvijo, da uporabljajo možnosti elektronskega povezovanja s poslovnimi partnerji (povprečna vrednost $=4,89$ ), najmanj pa s trditvijo, da $\mathrm{v}$ organizaciji uporabljajo posebna 
orodja za management odnosov z odjemalci (CRM) (povprečna vrednost $=3,74)$. Ostali podatki so razvidni iz preglednice 55 .

Preglednica 55: Procesna informacijska tehnologija

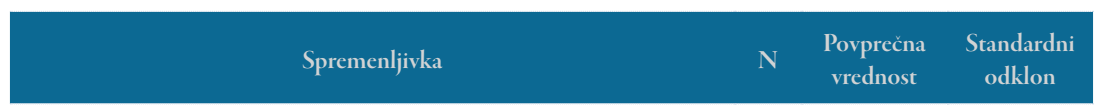

\begin{tabular}{|c|c|c|c|}
\hline Uporabljamo možnosti elektronskega povezovanja s poslovnimi partnerji. & 213 & 4,89 & I,6I \\
\hline Informatizacija poslovanja temelji na procesih (ne na poslovnih funkcijah). & 217 & 4,44 & $\mathrm{I}, 47$ \\
\hline $\begin{array}{l}\text { Naš informacijski sistem vodstvu zagotavlja relevantne informacije o us- } \\
\text { pešnosti in učinkovitosti procesov. }\end{array}$ & 215 & 4,29 & $\mathrm{I}, 5 \mathrm{I}$ \\
\hline
\end{tabular}

V organizaciji uporabljamo specializirana orodja za management poslovnih procesov (omogočajo modeliranje, avtomatizacijo, izvajanje, spremljanje $\quad 184 \quad 4,25 \quad$ I,71 poslovnih procesov).

\begin{tabular}{llll}
\hline Naš informacijski sistem je fleksibilen in podpira spreminjanje procesov. & 228 & 3,99 & 1,65 \\
\hline Uporabljamo posebna orodja za management odnosov z odjemalci (CRM). & 174 & 3,74 & 1,84 \\
\hline
\end{tabular}

\section{Faktorska analiza - procesna informacijska tehnologija}

Faktorska analiza je pokazala, da so podatki primerni za analizo (KMO $=0,830 ;$ Bartlettov test sig $=0,000)-$ preglednica 56 .

Preglednica 56: KMO in Bartlettov test - procesna informacijska tehnologija

\begin{tabular}{lcc} 
& Kaiser-Meyer-Olkin - KMO & 0,830 \\
Bartlettov Test & Hi-kvadrat & 351,405 \\
\cline { 2 - 2 } & sig & 15 \\
\hline
\end{tabular}

Glede na to, da so bile vse komunalitete posameznih spremenljivk višje od 0,400 , smo obdržali vse spremenljivke. V preglednici 57 je prikazana nova komponenta, ki pojasni $56,94 \%$ celotne variance. 
Preglednica 57: Celotna pojasnjena varianca - procesna informacijska tehnologija

\begin{tabular}{ccccccc}
\multicolumn{3}{c}{ Začetne lastne vrednosti } & \multicolumn{3}{c}{ Ekstrakcijski seštevki kvadratov uteži } \\
\hline Faktor & Skupaj & $\begin{array}{c}\text { Delež } \\
\text { variance v } \%\end{array}$ & Kumulativa v \% & Skupaj & $\begin{array}{c}\text { Delež } \\
\text { variance v \% }\end{array}$ & Kumulativa v \% \\
\hline I & 3,416 & 56,940 & 56,940 & 3,416 & 56,940 & 56,940 \\
\hline 2 & 0,905 & 15,086 & 72,026 & & \\
\hline 3 & 0,557 & 9,282 & 81,308 & & \\
\hline 4 & 0,451 & 7,511 & 88,819 & & \\
\hline 5 & 0,397 & 6,608 & 95,427 & & \\
\hline 6 & 0,274 & 4,573 & 100,000 & & \\
\hline
\end{tabular}

Novo spremenljivko smo imenovali »Procesna informacijska tehnologija«. Uteži posameznih spremenljivk, vključenih v novo spremenljivko, so razvidne iz preglednice 58 .

Preglednica 58: Uteži posameznih spremenljivk, vključenih v novo spremenljivko »Procesna informacijska tehnologija $\ll$

Spremenljivka

Q14a Naš informacijski sistem vodstvu zagotavlja relevantne informacije o uspešnosti in učinkovitosti procesov.

QI4b Naš informacijski sistem je fleksibilen in podpira spreminjanje procesov. $\quad$ 0,798

QI4c Uporabljamo možnosti elektronskega povezovanja s poslovnimi partnerji. $\quad 0,763$

Qi4d Uporabljamo posebna orodjaza menedžment odnosov z odjemalci (CRM). $\quad$ 0,759

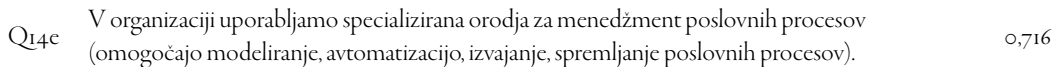

Q $14 \mathrm{f}$ Informatizacija poslovanja temelji na procesih (ne na poslovnih funkcijah). $\quad 0,634$

Za novo spremenljivko »Procesna informacijska tehnologija $\ll$ smo izračunali povprečno vrednost in standardni odklon - preglednica 59.

Preglednica 59: Povprečna vrednost in standardni odklon nove spremenljivke »Procesna informacijska tehnologija $\ll$ 


\section{Preverjanje zastavljenih hipotez}

$\mathrm{V}$ nadaljevanju preverjamo naslednje hipoteze:

- Hipoteza I: Slabša razvitost »mehkih«elementov, povezanih z voditeljstvom, kot so procesna organizacijsk a kultura, procesna organizacijska struktura in upravljanje z zaposlenimi, zmanjsuje raven procesne usmerjenosti organizacij.

- Hipoteza 2: Srednji in nižji management kritičneje ocenjujeta uspešnost udejanjanja procesne usmerjenosti in managementa poslovnih procesov od vrhnjega vodstva.

Hipotezo I preverimo:

- $s$ korelacijsko analizo, $s$ katero ugotavljamo povezanost med »mehkimi « elementi procesne usmerjenosti, povezanimi z voditeljstvom in ravnjo procesne usmerjenosti v dejavnosti;

- $\mathrm{z}$ regresijsko analizo, s katero ugotavljamo vpliv $\gg$ mehkih $\ll$ elementov procesne usmerjenosti, povezanih z voditeljstvom (neodvisna spremenljivka), na raven procesne usmerjenosti organizacij (odvisna spremenljivka).

Korelacijska analiza (preglednica 6o) je pokazala, da med procesno organizacijsko kulturo, procesno organizacijsko strukturo, upravljanjem $\mathrm{z}$ zaposlenimi in procesno usmerjenostjo organizacij obstaja pozitivna srednje močna povezanost (razpon korelacij od 0,599 do o,649). Ugotavljamo, da slabša razvitost »mehkih « elementov procesne usmerjenosti, ki so povezani z voditeljstvom, kot so procesna organizacijska kultura, procesna organizacijska struktura in upravljanje z zaposlenimi, zmanjšuje raven procesne usmerjenosti organizacij - in obratno. Hipotezo Hı sprejmemo.

\section{Preglednica 6o: Korelacijska analiza}

\begin{tabular}{llc} 
& & $\begin{array}{c}\text { Naša organizacija je zelo procesno } \\
\text { usmerjena }\end{array}$ \\
\cline { 2 - 3 } Procesna organizacijska kultura & Pearsonov koeficient korelacije & $0,639^{*}$ \\
\cline { 2 - 3 } & Sig. (2-stranska) & 0,000 \\
\cline { 2 - 3 } Procesna organizacijska struktura & Pearsonov koeficient korelacije & 210 \\
\cline { 2 - 3 } & Sig. (2-stranska) & $0,599^{*}$ \\
\cline { 2 - 3 } & $\mathrm{N}$ & 0,000 \\
\hline
\end{tabular}




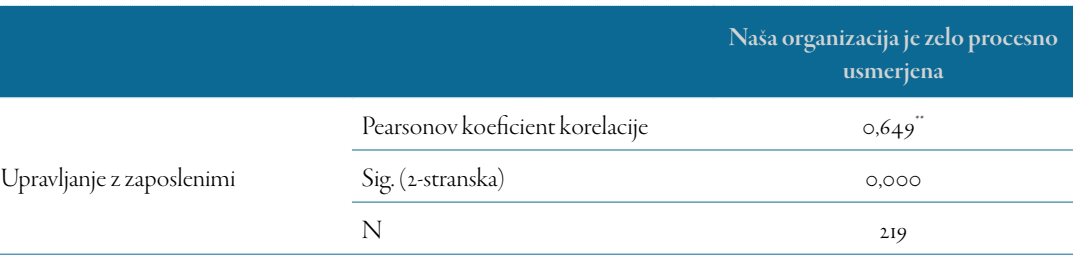

${ }^{* *}$ Korelacija je signifikantna pri o,or.

V nadaljevanju nas je zanimalo, kakšen je vpliv posameznih $\gg$ mehkih« elementov procesne usmerjenosti, ki so povezani z voditeljstvom, na raven procesne usmerjenosti organizacij. V ta namen smo izvedli multiplo regresijsko analizo (uporabili smo metodo enter). Ugotovili smo, da so ostanki normalno porazdeljeni - razvidno iz histograma in grafa standardiziranih regresijskih ostankov (Priloga 3).

Rezultat multiple regresijske analize (preglednica 6I) je pokazal, da na procesno usmerjenost organizacij pozitivno vplivajo vsi trije $\gg$ meh$\mathrm{ki}$ « elementi, ki so povezani z voditeljstvom, in sicer: procesna organizacijska struktura $(\beta=0,252$; sig $=0,039)$, procesna organizacijska kultura $(\beta=0,493$; sig $=0,000)$ in upravljanje z zaposlenimi $(B=0,298$; sig = o,oro). Regresijski model pojasni $52,5 \%$ variabilnosti procesne usmerjenosti organizacij.

Preglednica 61: Ocena regresijskih koeficientov $\mathrm{H}_{\mathrm{I}}$

\begin{tabular}{|c|c|c|c|c|c|c|}
\hline \multirow[b]{2}{*}{ Model } & \multicolumn{2}{|c|}{ Nestandardni koeficienti } & \multirow{2}{*}{$\begin{array}{c}\text { Standard- } \\
\text { ni koeficient } \\
\text { Beta }\end{array}$} & \multirow[b]{2}{*}{$\mathbf{R}^{2}$} & \multirow[b]{2}{*}{ t } & \multirow[b]{2}{*}{ sig } \\
\hline & Beta & $\begin{array}{c}\text { Standardna } \\
\text { napaka }\end{array}$ & & & & \\
\hline Konstanta & $-0,119$ & 0,396 & & 0,525 & $-0,300$ & 0,765 \\
\hline $\begin{array}{l}\text { Procesna organi- } \\
\text { zacijska struktura }\end{array}$ & 0,252 & $0,12 \mathrm{I}$ & 0,164 & & $2,08 \mathrm{I}$ & 0,039 \\
\hline $\begin{array}{l}\text { Procesna organi- } \\
\text { zacijska kultura }\end{array}$ & 0,493 & 0,112 & 0,391 & & 4,419 & 0,000 \\
\hline $\begin{array}{l}\text { Upravljanje z } \\
\text { zaposlenimi }\end{array}$ & 0,298 & O,II 4 & 0,236 & & 2,616 & ০,০।০ \\
\hline
\end{tabular}

Regresijsko funkcijo procesne usmerjenosti organizacij lahko zapišemo v obliki regresijske enačbe:

Procesna usmerjenost organizacij $=0,493{ }^{*}$ Procesna organizacijska kultura $+0,298^{*}$ Upravljanje $z$ zaposlenimi $+0,252$ * Procesna organizacijska struktura 
Parcialni regresijski koeficient ßi pove, koliko se spremeni odvisna spremenljivka Procesna usmerjenost organizacij, če se spremeni neodvisna spremenljivka Procesna organziacijska kultura za eno enoto, pri čemer so vse ostale neodvisne spremenljivke nespremenjene (lat. ceteris paribus).

\section{Hipoteza 2: Srednji in nižji management kritičneje ocenjujeta uspeš- nost udejanjanja procesne usmerjenosti in managementa poslovnih procesov od vrhnjega managementa.}

Za namen preverjanja hipoteze smo tri položajne skupine anketiranih razdelili v dve skupini, in sicer:

- prva skupina: vrhnji management (predsednik uprave ali generalni direktor oz. direktor družbe, član uprave, pomočnik predsednika uprave oziroma direktorja družbe, direktor oziroma izvršni direktor organizacijske enote);

- druga skupina: srednji in nižji management (vodja službe, vodja enote, vodja oddelka, vodja projekta).

Hipotezo smo preverili st-testom za neodvisne vzorce. Iz preglednice 62 je razvidno, da povprečne razlike pri ocenjevanju posameznih elementov procesne urejenosti glede na obe položajni skupini (vrhnji management, srednji in nižji management) niso statistično značilne (sig > 0,05) $\mathrm{v}$ povprečju obe skupini enako ocenjujeta posamezne elemente procesne urejenosti. Hipoteze $\mathrm{H}_{2}$ ne moremo sprejeti.

\section{Preglednica 62: T-test}

\begin{tabular}{llccc} 
& & N & $\begin{array}{c}\text { Povprečna } \\
\text { vrednost }\end{array}$ & Sig \\
\multirow{2}{*}{ Strateški vidik } & Vrhnji management & 33 & 4,91 & 0,931 \\
\cline { 2 - 5 } & Srednji in nižji management & 158 & 4,93 & \\
\hline \multirow{2}{*}{ Opremljenost in dokumentiranje procesov } & Vrhnji management & 32 & 5,23 & \multirow{2}{*}{0,943} \\
\cline { 2 - 5 } & Srednji in nižji management & 165 & 5,20 & \\
\hline \multirow{3}{*}{ Merjenje in management procesov } & Vrhnji management & 32 & 4,76 & \multirow{2}{*}{0,543} \\
\cline { 2 - 5 } & Srednji in nižji management & 183 & 4,95 & \\
\hline \multirow{2}{*}{ Procesna organizacijska struktura } & Vrhnji management & 31 & 4,93 & 0,351 \\
\cline { 2 - 5 } & Srednji in nižji management & 171 & 4,73 & \\
\hline \multirow{2}{*}{ Upravljanje z zaposlenimi } & Vrhnji management & 33 & 4,53 & 0,139 \\
\cline { 2 - 5 } & Srednji in nižji management & 192 & 4,39 & \\
\hline & &
\end{tabular}




\begin{tabular}{llccc} 
& & N & $\begin{array}{c}\text { Povprečna } \\
\text { vrednost }\end{array}$ & Sig \\
\multirow{2}{*}{ Procesna organizacijska kultura } & Vrhnji management & 31 & 4,75 & 0,165 \\
\cline { 2 - 5 } & Srednji in nižji management & I 84 & 4,58 & \\
\hline \multirow{2}{*}{ Tržna usmerjenost } & Vrhnji management & 32 & 4,54 & 0,085 \\
\cline { 2 - 5 } Vidik dobaviteljev (poslovnih partnerjev) & Srednji in nižji management & I40 & 4,63 & \\
\hline & Vrhnji management & 31 & 4,53 & 0,080 \\
\hline & Srednji in nižji management & I4I & 4,45 & \\
\hline Procesna in informacijska tehnologija & Vrhnji management & 31 & 3,97 & 0,312 \\
\cline { 2 - 5 } & Srednji in nižji management & II5 & 4,29 & \\
\hline
\end{tabular}

Primerjava zrelosti procesne usmerjenosti in poslovne uspešnosti elektrodistribucijskih organizacij

Za dosego četrtega cilja raziskave smo za vseh pet elektrodistribucijskih organizacij izmerjene vrednosti procesne usmerjenosti primerjali z rezultati izbranih kazalnikov uspešnosti.

\section{Izbor relevantnih kazalnikov poslovne uspešnosti}

Za celovitejši vpogled $\mathrm{v}$ uspešnost poslovanja smo izbrali 3-letno obdobje 20I2-20I4. Leta 2012 je takratna Agencija za upravljanje kapitalskih naložb Republike Slovenije (AUKN) v priporočilu št. I3 elektrodistribucijskim podjetjem priporočila uvedbo sistema 19 kazalnikov v sistem poročanja (AUKN 20I2, 46-47). Predlagani kazalniki vključujejo tako ekonomski, tehnični kot tehnično-ekonomski vidik poslovanja. Pregled poslovnih poročil organizacij v obravnavanem obdobju kaže, da le ena organizacija sistematično poroča o večini priporočenih kazalnikov (AJPES 2016). Zato smo kot izhodišče za analizo izbrali kazalnike, ki so jih v okviru prikaza finančnih učinkov investiranja na kazalnike poslovanja distribucijskih družb prikazali na Strateški konferenci elektrodistribucije Slovenije 2015: koeficient gospodarnosti poslovanja, donos na sredstva $\left(\mathrm{ROA}^{\prime}\right)$ in donos na kapital $\left(\mathrm{ROE}^{2}\right)$, poslovni prihodki na zaposlenega, dodana vrednost na zaposlenega in čisti dobiček na zaposlenega (Gorenc 20I5, I I). Ker gre za standardne in široko uveljavljene kazalnike, jih $\mathrm{v}$ okviru raziskave ne razlagamo. Vrednosti kazalnikov smo pridobili iz letnih poslovnih poročil organizacij (AJPES 2016). Poleg omenjenih kazalnikov smo v analizo vključili še dva za distribucijo specifična kazalni-

\footnotetext{
Angl. Return On Assets.

Angl. Return On Equity.
} 
ka neprekinjenosti napajanja: povprečno trajanje prekinitev napajanja $\mathrm{v}$ sistemu $\left(\mathrm{SAIDI}^{3}\right)$ in povprečno frekvenco prekinitev napajanja $\mathrm{v}$ sistemu $\left(\mathrm{SAIFI}^{4}\right)$. SAIDI je razmerje med vsoto trajanja prekinitev napajanja posameznih uporabnikov $\mathrm{v}$ določenem časovnem intervalu in celotnim številom uporabnikov v sistemu za čas trajanja tega časovnega intervala. SAIFI je razmerje med celotnim številom prekinitev napajanja uporabnikov $\mathrm{v}$ določenem časovnem intervalu in celotnim številom uporabnikov $\mathrm{v}$ sistemu za čas trajanja tega časovnega intervala (Agencija za energijo 20ı6b, 6955). Pri kazalnikih SAIDI in SAIFI smo upoštevali le nenačrtovane dolgotrajne prekinitve (daljše od treh minut), ki so posledica lastnih vzrokov, tj. obvladovanja procesov. $V$ analizi torej nismo upoštevali načrtovanih prekinitev zaradi tujih vplivov in višje sile ter načrtovanih prekinitev zaradi vzdrževanj, obnov ipd. Vrednosti kazalnikov SAIDI in SAIFI smo pridobili iz $\gg$ Poročila o stanju na področju energetike v Sloveniji v letu 2014《 (Republika Slovenija, Ministrstvo za infrastrukturo 2015a, 24).

Glede na javno dostopne podatke smo v analizo vključili skupaj $8 \mathrm{ka}-$ zalnikov uspešnosti organizacij, 6 ekonomskih in 2 kazalnika neprekinjenosti napajanja.

\section{Analiza in predstavitev rezultatov}

Zaradi števila managerjev $\mathrm{v}$ elektrodistribucijskih organizacijah in $\mathrm{s}$ tem povezanih majhnih vzorcev (med I i in 17 izpolnjenih vprašalnikov, le $\mathrm{v}$ eni organizaciji 32) ter le 8 kazalnikov uspešnosti niso izpolnjeni pogoji za uporabo parametričnih statističnih metod ali neparametričnih testov.

Zato smo izbrane rezultate lahko le medsebojno primerjali in jih rangirali po uspešnosti. Na osnovi tako dobljenih rangov smo izračunali njihove povprečne vrednosti in jih primerjali z izmerjenimi vrednostmi procesne usmerjenosti ter tako pridobili vpogled $\mathrm{v}$ morebitno povezanost zrelosti procesne usmerjenosti in poslovne uspešnosti obravnavanih organizacij.

Potek analize in rezultati so prikazani v Prilogi 4 . Ker gre za medsebojne primerjave med elektrodistribucijskimi organizacijami, so namesto nazivov organizacij uporabljene oznake A, B, C, D in E. Rezultati analize kažejo, da se razvrstitev uspešnosti organizacij na osnovi obravnavanih kazalnikov $\mathrm{v}$ celoti ujema $\mathrm{z}$ razvrstitvijo izmerjenih ravni procesne usmerjenosti. Poslovno najuspešnejša organizacija ima tudi najvišjo raven izmerjene procesne usmerjenosti in obratno. Pri najmanj poslovno uspešni organizaciji smo izmerili najnižjo raven procesne usmerjenosti. Seve-

Angl. System Average Interruption Duration Index.

4 Angl. System Average Interruption Frequency Index. 
da nam uporabljen pristop $\mathrm{k}$ primerjavi ponuja zgolj vpogled v potencialno povezanost zrelosti procesne usmerjenosti in poslovne uspešnosti organizacij. Brez statistično verodostojnih potrditev ni mogoče sklepati na vzročno-posledične povezave med razvitostjo procesne usmerjenosti in poslovno uspešnostjo. So pa lahko rezultati te primerjave pomembna spodbuda za nadaljnje izboljševanje uspešnosti in učinkovitosti procesov v praksi.

Pri uporabi rezultatov primerjave je seveda potrebno upoštevati vrsto omejitev. V analizo smo vključili le omejen nabor kazalnikov uspešnosti, ki ne pokrivajo vseh pomembnih vidikov dolgoročne uspešnosti poslovanja. Tako za organizacije kot za prihodnje raziskave se priložnost kaže $\mathrm{v}$ razvoju in uporabi primernega sistema uravnoteženih kazalnikov (Janeš 20I5). Obravnavano 3-letno obdobje omogoča analizo zgolj 2-letnega trenda, kar je v panogi elektrodistribucije izjemno kratko obdobje. $\mathrm{Ob}$ tem je kot dodatno omejitev potrebno upoštevati katastrofalni žled februarja 2014, ki je različna geografska področja in $s$ tem elektrodistribucijske organizacije zelo različno prizadel, tudi zaradi velikih razlik med organizacijami v deležu kabliranega omrežja. Najpomembnejšo omejitev predstavlja način izvedbe analize, saj ne sloni na statističnem vrednotenju in potrjevanju. Istočasno je to lahko izziv za prihodnja raziskovanja. $\mathrm{Z}$ vključitvijo vseh zaposlenih $\mathrm{v}$ merjenje procesne usmerjenosti bi lahko pridobili dovolj velike vzorce za statistično vrednotenje in potrjevanje. 



\section{Sklep}

V pogojih globalizacije poslovanja, interneta in e-poslovanja ter številnih vedno novih tehnologij je potreba po procesni usmerjenosti in delovanju organizacij še toliko večja. Za uspešno razvijanje in udejanjanje procesne usmerjenosti sta najpomembnejša zavedanje vodstva o njenem pomenu in vplivu na uspešnost poslovanja ter celostni, strateški pristop $\mathrm{k}$ managementu poslovnih procesov. To pomeni, da je BPM integralni del managementa organizacije, ki sloni na procesni arhitekturi in povezanosti procesov s strategijo, cilji in politikami organizacije. Predpogoj uspešnega managementa je upravljanje procesov, ki vzpostavlja pogoje ter skozi usmeritve in nadzor nenehno zagotavlja pričakovane rezultate procesov $\mathrm{v}$ podporo uresničevanju strategije. Ob zavedanju in vključenosti vodstva so ključni dejavniki uspešnega BPM nedvoumno določeno in razumljeno skrbništvo procesov, pravi kazalniki za merjenje uspešnosti procesov, procesom prijazna organizacijska kultura ter procesno naravnan informacijski sistem. Težave na področju merjenja in ocenjevanja uspešnosti procesov pogosto izvirajo iz dejstva, da cilji procesov niso izpeljani iz strateških ciljev organizacije. V praksi se BPM potrjuje kot primeren način inoviranja in transformiranja organizacij ter razvijanja njihove agilnosti. Vendar tudi sam BPM potrebuje spremembe, ki jih $\mathrm{v}$ dobi digitalizacije $\mathrm{v}$ največji meri narekuje hiter razvoj informacijskih in komunikacijskih tehnologij. Čeprav številni avtorji poudarjajo pomen procesne usmerjenosti za poslovno uspešnost organizacij, pa na podlagi pregleda obsežne literature na tem področju še vedno ni celovitih raziskav, ki bi nedvoumno potrjevale pozitiven vpliv procesne usmerjenosti na uspešnost poslovanja. 
Organizacije z razvijanjem zmogljivosti procesov, managementa procesov in procesne usmerjenosti dosegajo višnje stopnje zrelosti in s tem odličnosti procesov in rezultatov. Zrelostni modeli organizacijam pomagajo ocenjevati doseženo stopnjo na poti v odličnost poslovnih procesov. $\mathrm{V}$ zadnjih dveh desetletjih je bilo razvitih na desetine modelov za ocenjevanje zrelosti procesov, zrelosti managementa procesov in zrelosti procesne usmerjenosti. Čeprav praksa potrjuje njihovo uporabnost za nenehno izboljševanje, pa še ni celovite primerjalne študije zrelostnih modelov $\mathrm{z}$ vidika koristnosti uporabe pri povečevanju uspešnosti procesov in poslovne uspešnosti organizacij.

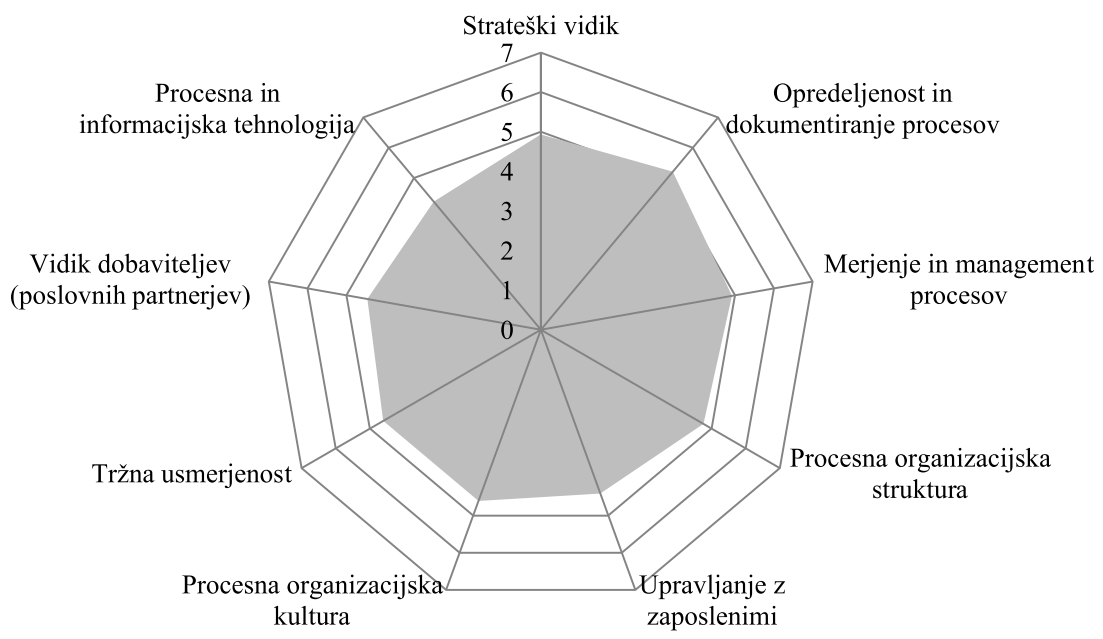

Slika 34: Statistično ovrednotene ocene elementov procesne usmerjenosti

Rezultati merjenja zrelosti procesne usmerjenosti v elektroenergetski dejavnosti kažejo, da ta kljub dolgoletnemu ukvarjanju s procesi, uvajanju procesnega pristopa, certificiranim sistemom vodenja in informatizaciji poslovanja ni visoka. Glede trditve »Naša organizacija je zelo procesno usmerjena « so se v raziskavo zajeti managerji v povprečju strinjali, vendar znaša povprečna ocena le 4,73. Skoraj identično oceno smo dobili s statističnim ovrednotenjem izmerjenih vrednosti posameznih elementov procesne usmerjenosti (povprečna vrednost 4,68). Najbolje ocenjeni elementi procesne usmerjenosti so opredeljenost in dokumentiranje procesov $(5,21)$, strateški vidik $(4,93)$ in merjenje $(4,92)$. Opredeljenost in dokumentiranje je pričakovano najvišje ocenjen element, saj kar 70,8 \% anketiranih meni, da imajo v organizaciji posebno organizacijsko enoto ali del organizacijske enote, ki lastnikom procesov pri tem zagotavlja stro- 
kovno podporo. Najslabše ocenjeni elementi so informacijska tehnologija $(4,22)$, upravljanje z zaposlenimi $(4,4 \mathrm{I})$ in vidik dobaviteljev $(4,46)$. Preseneča najnižja ocena informacijske tehnologije, ki predvsem znotraj posameznih organizacij zasluži podrobnejšo analizo in primerno ukrepanje. Povprečne vrednosti elementov procesne usmerjenosti prikazuje slika 34.

Glede na izračunano povprečno vrednost procesne usmerjenosti se elektroenergetska dejavnost nahaja na 2. stopnji McCormackovega zrelostnega modela, Definirano. Za to stopnjo je značilno, da so procesi opredeljeni in dokumentirani. Spremembe procesov potekajo na osnovi formalnih postopkov. Delovna mesta in organizacijske strukture že vključujejo procesni vidik, dejansko pa ostajajo funkcijske (McCormack 2007, 62).

Analiza rezultatov opozarja na potrebo po boljšem komuniciranju z zaposlenimi. Med najnižje ali nizko ocenjenimi trditvami v posameznih elementih so trditve glede seznanjenosti zaposlenih s strateškimi cilji, z rezultati kazalnikov in doseganjem ciljnih vrednosti procesov ter s predvidenimi spremembami. Elektroenergetska dejavnost je izrazito tehnična dejavnost, zato tudi med managerji prevladuje tehnični kader. Zato ne preseneča, da je drugi najslabše ocenjeni element prav upravljanje $\mathrm{z}$ zaposlenimi. Zaposleni slabo poznajo metode in tehnike izboljševanja procesov $(4,22)$ in niso stimulirani za predloge izboljšav procesov $(3,25)$, kar lahko predstavlja resno oviro za nadaljnje izboljševanje uspešnosti in učinkovitosti procesov ter posledično uspešnost organizacij. Procesna organizacijska struktura $(4,6 \mathrm{I})$ in struktura $(4,76)$ sta le nekoliko bolje ocenjeni. $S$ korelacijsko in regresijsko analizo smo ugotovili, da slabša razvitost »mehkih « elementov procesne usmerjenosti, ki so povezani $z$ voditeljstvom, kot so procesna organizacijska kultura, procesna organizacijska struktura in upravljanje $\mathrm{z}$ zaposlenimi, zmanjšujejo raven procesne usmerjenosti organizacij. $S$ tem smo potrdili hipotezo I. Naše ugotovitve predstavljajo dragoceno povratno informacijo vrhnjemu managementu v elektroenergetski dejavnosti o nujnosti vlaganja $\mathrm{v}$ zaposlene, o pomembnosti razvijanja procesne organizacijske kulture in procesne organizacijske strukture.

$S$ preverjanjem $s$ t-testom za neodvisne vzorce smo ugotovili, da med ocenami posameznih elementov procesne urejenosti s strani vrhnjega managementa na eni ter srednjega in nižjega managementa na drugi strani ni statistično značilnih razlik. Dejstvo, da hipoteze 2 ne moremo sprejeti, je spodbudno, saj managerji na različnih ravneh vodenja zelo podobno ocenjujejo stanje na področju procesne usmerjenosti. Glede na ugotovljene pomanjkljivosti na področju dela z zaposlenimi, še posebej komunici- 
ranja, je preverjanje razlik med ocenami managerjev in zaposlenih lahko priložnost za eno prihodnjih raziskav.

Monografija s teoretičnega vidika bralcu omogča celovit vpogled v uveljavljanje koncepta poslovnih procesov, managementa procesov, procesne usmerjenosti in zrelostnih modelov. Obravnavan je širok izbor literature $s$ teh področij, vključene so ugotovitve in dognanja nekaterih najnovejših študij. Predvsem praktiki, ki strokovno delajo na obravnavanem področju, bodo $\mathrm{v}$ monografiji našli koristne informacije in usmeritve za boljše razumevanje procesne usmerjenosti ter zrelostnih modelov in $s$ tem lažje ter uspešneje delali. S tem smo izpolnili i. in 2. cilj naše raziskave.

$\mathrm{Z}$ izmerjeno procesno usmerjenostjo, preverjanjem hipotez in prepoznano drugo zrelostno stopnjo, Definirano, smo ugotovili stanje procesne usmerjenosti v dejavnosti elektroenergetike in s tem izpolnili 3. cilj naše raziskave. Želimo si, da bi predvsem vrhnji management v dejavnosti prepoznal praktične koristi ugotovitev raziskave. Na osnovi najnižje ocenjenih trditev in elementov procesne usmerjenosti ter poznavanja in razumevanja točk preloma, katerih pomen smo predstavili v razdelku 4.4, se lahko pripravi konkreten program izboljšav za uveljavitev procesne usmerjenosti in prehod na 3. stopnjo zrelosti, Povezani. Dodatno spodbudo v tej smeri lahko predstavlja tudi naš vpogled v povezanost med razvitostjo procesne usmerjenosti in poslovne uspešnosti elektrodistribucijskih organizacij, kar je bil 4. cilj raziskave.

Seveda je pri uporabi ugotovitev raziskave potrebno upoštevati vrsto omejitev. Prvo omejitev predstavlja dejstvo, da je bila meritev zrelosti procesne usmerjenosti izvedena na omejenem vzorcu organizacij elektroenergetske dejavnosti. Druga omejitev se nanaša na čas, v katerem je bila meritev izvedena. Del dejavnosti je $v$ resnih finančnih težavah, ki odpirajo vprašanja prestrukturiranja in nadaljnjega razvoja nekaterih družb v skupini HSE. Napovedana splošna opozorilna stavka sindikata delavcev dejavnosti energetike Slovenije (SDE) je v času zaključevanja raziskave postala dejstvo. Ob tem je merjenje časovno sovpadlo s postopki menjave vrhnjega managerja $\mathrm{v}$ kar treh organizacijah, kar je predstavljalo dodatno omejitev. Omejitve, povezane s primerjavo med izmerjeno procesno usmerjenostjo in poslovno uspešnostjo elektrodistribucijskih organizacij, smo navedli v razdelku 7.2.2. Tovrstni rezultati imajo značaj poslovne skrivnosti, kar za raziskavo prav tako predstavlja določeno omejitev. 


\section{Literatura in viri}

\section{Literatura}

Albliwi, Saja, Jiju Antony, Sarina Abdul Halim Lim in Ton van der Wiele. 2014. »Critical Failure Factors of Lean Six Sigma: A Systematic Literature Review.« International Journal of Quality \& Reliability Management 3 I (9): 1012-30.

Andersson, Roy, Henrik Eriksson in Håkan Torstensson. 2006. »Similarities and Differences between TQM, Six Sigma and Lean.« The TQM Magazine I 8 (3): 282-96.

Andersson, Roy, Per Hilletofth, Peter Manfredsson in Olli-Pekka Hilmola. 2014. »Lean Six Sigma Strategy in Telecom Manufacturing.« Industrial Management \& Data Systems I I 4 (6): 904-2 I.

Antony, Jiju. 20 I. »Six Sigma vs Lean.«International Journal of Productivity and Performance Management 60 (2): i 85-90.

Arumugam, V., Jiju Antony in Alex Douglas. 2012. »Observation: A Lean Tool for Improving the Effectiveness of Lean Six Sigma.« The TQM Journal 24 (3): 275-87.

Assarlind, Marcus, Ida Gremyr in Kristoffer Bäckman. 2013. »Multi-Faceted Views on a Lean Six Sigma Application.«International Journal of Quality \& Reliability Management 30 (4): 387-402.

APQC (Ameriški center za produktivnost in kakovost). 2010. »APQC Process Classification Framework (PCF).« https://www.apqc.org/ knowledge-base/documents/apqc-process-classification-framework-pcf-cross-industry-excel-version-702. 
ASQ (Ameriško združenje za kakovost). 20I6. »Total Quality Management (TQM).« http://asq.org/learn-about-quality/total-quality-management/ overview/overview.html.

Athayde William P., Deborah Bigelow Crawford, Ruth Elswick in Paul Lombard. 2007. Project Management Essentials. Havertown: PM College.

Bendell, Tony. 2006. »A Review and Comparison of Six Sigma and the Lean Organizations.« The TQM Magazine I 8 (3): 255-62.

Bhat, Shreeranga, E. V. Gijo in N. A. Jnanesh. 2014. »Application of Lean Six Sigma Methodology in the Registration Process of a Hospital.« International Journal of Productivity and Performance management 63 (5): 613-43.

Biloslavo, Roberto. 2008. Strateški management in management spreminjanja. Koper: Fakulteta za management Koper.

Bolsinger, Manuel, Anna Elsäßer, Caroline Helm in Maximilian Röglinger. 2015. »Process Improvement through Economically Driven Routing of Instances.« Business Process Management Journal 2 I (2): 353-78.

BPTrends. 2013. »Business Process Management (BPM).« http://www.bptrends. $\mathrm{com} /$ resources/glossary/business-process-management-bpm/.

Burlton, Roger T. 200 I. Business Process Management. Profiting from Process. Indianapolis: Sams Publishing.

Burlton, Roger T. 2006. »Best Practices of Process Management: The Top Ten Principles (part I).«Business Rules Journal 7 (I). http://www.brcommunity.com/b269.php.

Burlton, Roger T. 2015. »Delivering Business Strategy through Process Management.« V Handbook on Business Process Management 2, Strategic Alignment, Governance, People and Culture, 2 nd ed., ur. Jan vom Brocke in Michael Rosemann, 45-78. Berlin: Springer-Verlag.

Byrne, John A. 1993. »The Horizontal Corporation.« http://www.bloomberg.com/bw/stories/1993-I2-19/the-horizontal-corporation.

Champy, James. 2002. X-engineering the Corporation. Reinventing Your Business in the Digital Age. New York: Warner Business Books.

Chang, James F. 2006. Process Management Systems. Strategy and Implementation. New York: Auerbach Publications.

Christensen, William, Richard Germain in Laura Birou. 2007. »Variance vs Average: Supply Chain Lead-Time as a Predictor of Financial Performance.« Supply Chain Management: an International Journal I 2 (5): 349-57. 
CMMI Institut (Capability Matiruty Model Integration Institut). 2010. $\gg C M M I^{\circ}$ for Services, Version $1.3 . \ll$ http://cmmiinstitute.com/cmmi-models.

Cronemyr, Peter, in Mikael Danielsson. 2013. »Process Management I-2-3 - A Maturity Model and Diagnostic Tool.« Total Quality Management 24 (8): $933-44$.

Crosby, Philip B. 1990. Kakovost je zastonj. Umetnost zagotavljanja kakovosti. Ljubljana: Gospodarski vestnik.

Dahlgaard, Jens J., in Su Mi Dahlgaard-Park. 2006. »Lean Production, Six Sigma Quality, TQM and Company Culture.«TQM Magazine I8 (3): 263-8I.

Davenport, Thomas H. 1993. Process Inovation. Reengineering Work through Information Technology. Boston: Harcard Business School Press.

Davenport, Thomas H. 2005. »The Coming Commoditization of Processes.« http://hbr.org/2005/06/the-coming-commoditization-of-processes/ar/I.

Deblois, Simon, in Luigi Lepanto. 2016. »Lean and Six Sigma in Acute Care: A Systematic Review of Reviews.«International Journal of $\mathrm{He}$ alth Care Quality Assurance 29 (2): 192-208.

De Boer, Fernanda G., Cláudio J. Müller in Carla Schwengber ten Caten. 2015. \Assessment Model for Organizational Business Process Maturity with a Focus on BPM Governance Practices. « Business Process Management Journal 2 I (4): 908-27.

De Bono, Edward. 2006. Lateralno razmisljanje. Ljubljana: New moment.

Deming, Edvard W. 1986. Out of the Crisis. Cambridge: MIT Press.

De Morais, Rinaldo Macedo, Samir Kazan, Silvia Inês Dallavalle de Pádua in André Lucirton Costa. 2014. »An Analysis of BPM Lifecycles: From a Literature Review to a Framework Proposal.« Business Process Management Journal 20 (3): 412-32.

DeToro, Irving, in Thomas McCabe. 1997. »How to Stay Flexible and Elude Fads.« Quality Progres 30 (3): 55-60.

Galbraith, Jay R. 2005. Designing the Customer-Centric Organization. A Guide to Strategy, Structure, and Process. San Francisco: Jossey-Bass.

Gardner, Robert. 2004. The Process-focused Organization: A Transition Strategy for Success. Milwaukee: ASQ.

Goldenson, Dennis, Joe Jarzombek in Terry Rout. 2003. »Measurement and Analysis in Capability Maturity Model Integration Models and Software Pro- 
cess Improvement.« http://resources.sei.cmu.edu/library/asset-view.cfm?assetid $=29529$.

Hair, Joseph H., Barry J. Babin, Rolph E. Anderson in Ronald L. Tatham. 2006. Multivariate Data Analysis. New Jersey: Pearson Prentice Hall.

Hamel, Gary. 201 4. »Bureaucracy Must Die.« https://hbr.org./201 4/I I/bureaucracy-must-die.

Hammer, Michael. 1990. »Reengineering Work: Don't Automate, Obliterate.« Harvard Business Review 34 (4): 104-I 2.

Hammer, Michael. 2002. »Process Management and the Future of Six Sigma.« MIT Sloan Management Review 43 (2): 26-32.

Hammer, Michael. 2007. »The Process Audit.« Harvard Business Review SI (4): I-I 4 .

Hammer, Michael, in James Champy. 1993. Reengineering the Corporation: A Manifesto for Business Revolution. New York: Harper Business.

Harmon, Paul. 2003. Business Process Change. A Manager's Guide to Improving, Redesigning, and Automating Processes. Amsterdam: Morgan Kaufmann.

Harmon, Paul. 20I0. »The Scope and Evolution of Business Process Management.« V Handbook on Business Process Management I. Introduction, Methods, and Information Systems. International Handbooks Information System, ur. Jan vom Brocke in Michael Rosemann, 37-81. Berlin: Springer-Verlag.

Harmon, Paul. 2014. Business Process Change. A Business Process Management Guide for Managers and Process Professionals. Waltham: Elsevier.

Harrington, James H. 1991. Business Process Improvement: The Breakthrough Strategy for Total Quality, Productivity, and Competitiveness. New York: McGraw-Hill.

Harrington, James H. 2006. Process Management Excellence. The Art of Excelling in Process Management. Chico: Paton Press.

Hernaus, Tomislav, Vesna B. Vukšić in Mojca I. Štemberger. 20I6. »How to Go from Strategy to Results? Institutionalising BPM Governance within Organisations.« Business Process Management Journal 22 (I): 17395.

Hilton, Roger John, in Amrik Sohal. 2012. »A Conceptual Model for the Successful Deployment of Lean Six Sigma.« International Journal of Quality \& Reliability Management 29 (I): 54-70.

Hines, Peter, Pauline Fond, Gary Griffiths in Richard Harrison. 20 1 2. Ohranjanje vitkosti. Uspeti, ne le preživeti. Ljubljana: Slovenski institut za kakovost in meroslovje. 
Hove, Maria, Gabriella von Rosing in Bob Storms. 2015. »Business Process Management Governance. « V The Complete Business Process Handbook. Body of Knowledge from Process Modeling to BPM Volume I, ur. Mark Von Rosing, August Wilhelm Scheer in Henrik von Scheel, 599-6ri. Waltham: Elsevier.

Imai, Masaaki. 1986. Kaizen: The Key to Japan's Competitive Success. New York: McGraw-Hill.

IoT Agenda (Internet of Things Agenda). 2016. http://internetofthingsagenda. techtarget.com/definition/Internet-of-Things-IoT.

ISO (International Organization for Standardization). 2015. »The ISO Survey of Management System Standard Certifications - 2014. Executive Summary.« http://www.iso.org/iso/iso_survey_executive-summary. pdf?v2014.

Janeš, Aleksander. 2015. Razvoj sistema uravnoteženih kazalnikov. Koper: Fakulteta za management.

JUSE (Union of Japanese Scientists and Engineers). 20I6. http://www.juse. or.jp/english/profile/.

Jeston, John, in Johan Nelis. 2007. Business Process Management. Practical Guidelines to Successful Implementations. Amsterdam: Butterworth-Heinemann.

Kaplan, Robert S., in David P. Norton. 2001. The Strategy-Focused Organization: How the Balanced Scorecard Companies Thrive in the New Business Environment. Boston: Harvard Business School Press.

Kaizen Institute. 2016. »What is Kaizen?« https://www.kaizen.com/about-us/definition-of-kaizen.html.

Kemsley, Sandi. 2015. »Emerging Technologies in BPM.«V BPM - Driving Innovation in a Digital World, ur. Jan vom Brocke in Theresa Schmiedel, 5I-58. Heilderberg: Springer.

Kennerley, Mike, in Andy Neely. 2005. »Performance Measurement Frameworks: A Review.« V Business Performance Measurement. Theory and Practice, ur. Andy Neely, I45-55. Cambridge: Cambridge University Press.

Kirchmer, Mathias. 2009. High Performance through Process Excellence. From Strategy to Execution with Business Process Management. Berlin: Springer-Verlag.

Križman, Vojko, in Rajko Novak. 2002. Upravljanje poslovnih procesov. Ljubljana: Slovenski institut za kakovost in meroslovje. 
Laureani, Alessandro, Malcolm Brady in Jiju Antony. 2013. »Applications of Lean Six Sigma in an Irish Hospital.« Leadership in Health Services $26(4): 322-37$.

Lehman, Carl F. 2012. Strategy and Business Process Management.Techniques for Improving Execution, Adaptability, and Consistency. Boca Raton: Taylor \& Francis Group.

Liker, Jeffrey K. 2004. The Toyota Way. I4 Management Principles from the World's Greatest Manufacturer. New York: McGraw-Hill.

Markus, Lynne M., in Dax D. Jacobson. 2010 . »Business Process Governance.« V Handbook on Business Process Management 2, Strategic Alignment, Governance, People and Culture, ur. Jan vom Brocke in Michael Rosemann, 20I-38. Berlin: Springer-Verlag.

McCormack, Kevin. 2007. Business Process Maturity. Theory and Application. Kevin McCormack.

McCormack, Kevin, in William C. Johnson. 2001. Business Process Orientation: Gaining the E-Business Competitive Advantage. Boca Raton: St. Lucie Press.

McCormack, Kevin, Jurgen Willems, Joachim van den Bergh, Dirk Deschoolmeester, Peter Willaert, Mojca Indihar Štemberger, Rok Škrinjar, Peter Trkman, Marcelo Bronzo, Ladeira Marcos, Paulo Valadares de Oliveira, Vesna Bosilj Vuksic in Nikola Vlahović. 2009. »A Global Investigation of Key Turning Points in Business Process Maturity.« Business Process Management Journal is (5): 792-815.

Melan, Eugene. H. 1985. »Process Management in Service and Administrative Operations.« Quality Progress i 8 (6): 52-59.

Moen, Ronald, in Clifford Norman. 2006. »Evolution of the PDCA Cycle.« http://pkpinc.com/files/NAor MoenNormanFullpaper.pdf.

Møller, Charles. 2015. »Business Process Innovation as an Enabler of Proactive Value Chains.« V BPM - Driving Innovation in a Digital World, ur. Jan vom Brocke in Theresa Schmiedel, 17-29. Heidelberg: Springer.

Näslund, Dag. 2008. »Lean, Six Sigma and Lean Sigma: Fads or Real Process Improvement Methods? « Business Process Management Journal I 4 (3): $269-87$.

OECD (Organizacija za gospodarsko sodelovanje in razvoj). 2009. Načela korporativnega upravljanja OECD. Ljubljana: Socius.

OMG (Object Managemnt Group). 2008. \Business Process Maturity Model (BPMM) Version $1.0 . \ll$ http://www.omg.org/spec/BPMM/ı.o/PDF. 
Paulk, Mark C, Bill Curtis, Mary Beth Chrissis in Charles V. Weber. 1993. Capability Maturity Model for Software. Pittsburgh: Carnegie Mellon University.

Peters, Thomas J., in Nancy Austin. 1985. A Passion for Excellence. The Leadership Difference. New York: Random House.

PMI (Project Management Institute). 2008. Vodnik po znanju projektnega vodenja: (PMBOK vodnik). Kranj: Moderna organizacija.

Poeppelbuss, Jens, Ralf Plattfaut in Bjoern Niehaves. 2015. »How Do We Progress? An Exploration of Alternate Explanations for BPM Capability Development.« Communications Of The Association For Information Systems 36 (I): I-22.

Porter, Michael E. 1985. Competitive Advantage: Creating and Sustaining Superior Performance. New York: Free Press.

Prosen, Tina, in Rajko Novak. 20ı. »Uvajanje procesne usmerjenosti v Ljubljanskih mlekarnah.« http://konference.ef.uni-lj.si/previous/ $\mathrm{mpp} / 2010 /$.

Raynus, Joseph. 20 I I. Improving Business Process Performance. Gain Agility, Create Value, and Achieve Success. New York: CRC Press.

Redinius, Don L. 2004. »The Convergence of Six Sigma and Process Management.« $\quad$ http://www.bptrends.com/bpt/wp-content/publicationfiles/I 2-04\%2oART\%гоBPM\%гоSixSigma\%2oConvergence\%2o-\%2oRedinius.pdf.

Richardson, Clay. 2006. »Process Governance Best Practices: Building a BPM Center of Excellence.« http://www.bptrends.com/publicationfiles/o9-o6-ART-ProcessGovernanceBestPractices-Richardson I.pdf.

Roeser, Tobias, in Eva-Maria Kern. 2015. »Surveys in Business Process Management - A Literature Review.« Business Process Management Journal 2 I (3): 692-718.

Rosemann, Michael, in Tonia de Bruin. 2005. »Towards a Business Process Management Maturity Model.« https://www.researchgate.net/publication $/ 27482324$.

Rosemann, Michael, in Jan vom Brocke. 2010. »The Six Core Elements of Business Process Management.«V Handbook on Business Process Management, Vol. I, ur. Jan vom Brocke in Michael Rosemann, 107-22. New York: Springer.

Röglinger, Maximilian, Jens Pöppelbuß in Jörg Becker. 20I 2. \Maturity Models in Business Process Management.« Business Process Management Journal i 8 (2): 328-46. 
Rummler, Geary A., in Alan Brache P. 1990. Improving Performance: How to Manage the White Space on the Organization Chart. San Francisco: Jossey-Bass.

Schmiedel, Theresa, in Jan Vom Brocke. 2015. »Business Process Management: Potentials and Challenges of Driving Innovation. $\ll B P M-D r i-$ ving Innovation in a Digital World, ur. Jan vom Brocke in Theresa Schmiedel, 3-I 5. Heidelberg: Springer.

SEI (Software Engineering Institute). 2016. »CMMI Tool and Methods.« http://www.sei.cmu.edu/acquisition/tools/index.cfm.

Sharp, Alec, in Patrick McDermott. 2009. Workfloww Modeling, Tools for Process Improvement and Application Development. Boston: Artech House.

SIST (Slovenski inštitut za standardizacijo). 2000. SIST EN ISO goor:2000 Sistem vodenja kakovosti - Zahteve (ISO goor:20oo). Ljubljana: SIST.

SIST (Slovenski inštitut za standardizacijo). 2005. SIST EN ISO g000:2005 Sistem vodenja kakovosti - Osnove in slovar (istoveten EN ISO gooo:2005). Ljubljana: SIST.

SIST (Slovenski inštitut za standardizacijo). 2015. SIST EN ISO goor:20Is Sistem vodenja kakovosti - Zahteve (ISO goor:2015). Ljubljana: SIST.

Skalle, Hans, in Bill Hahn. 2013. »Applying Lean, Six Sigma, BPM, and SOA to Drive Business Results. Redguides for Business Leaders. «ttp://www.redbooks.ibm.com/redpapers/pdfs/redp4447.pdf.

Sloko CIGRÉ. 200 I. Slovenski elektrotehniški slovar. Področje energetika. Trg električne energije. Ljubljana: Sloko CIGRÉ.

Smart Process Manufacturing Engineering Virtual Organization Steering Committee. 2009. »Smart Process Manufacturing. An Operations and Technology Roadmap.« https://smartmanufacturingcoalition.org/sites/default/files/spm___an_operations_and_technology_roadmap.pdf.

Smith, Adam. 2010. Bogastvo narodov. Ljubljana: Studia Humanitatis.

Smith, Ralph. 2007. Business Process Management and the Ballanced Scorecard: Using Processes as Strategic Drivers. New York: John Wiley \& Sons.

Smith, Howard, in Peter Fingar. 2003. Business Process Management: The Third Wave. Tampa: Meghan-Kiffer Press.

Snee, Ronald D. 1999. »Why Should Statisticians Pay Attention to Six Sigma? « Quality Progress 32 (9): 100-03.

Spany, Endrew. 2007. More for Less. The Power of Process Managment. Tampa: Mefhan-Kiffer Press. 
Škrinjar, Rok. 20Io. »Povečanje zrelosti procesne usmerjenosti s prenovo in informatizacijo poslovanja.« Doktorska disertacija, Univerza v Ljubljani.

Trkman, Peter, in Monika Klun. 2015. »Leveraging Social Media for Process Innovation. A Conceptual Framework.« V BPM - Driving Innovation in a Digital World, ur. Jan vom Brocke in Theresa Schmiedel, 3-15. Heidelberg: Springer.

Van den Bergh, Joachim, Öykü Işik, Stijn Viaene in Eddy Helsen. 2016. »Repositioning Business Process Management.« http://www.bptrends.com/repositioning-business-process-management/.

Van Looy, Amy. 2014. Business Process Maturity. A Comparative Study on a Sample of Business Process Maturity Models. New York: Springer.

Van Looy, Amy, Manu De Backer in Geert Poels. 20 I I. »Defining Business Process Maturity. A Journey towards Excellence.«Total Quality Management \& Business Excellence 22 (I I): I I 19-37.

Van Looy, Amy, Manu De Backer, Geert Poels in Monique Snoeck. 2013. $\gg$ Choosing the Right Business Process Maturity model.« Information \& Management 50 (7): 466-88.

$\mathrm{Zu}$, Xingxing, Tina L. Robbins in Lawrence D. Fredendall. 2010. »Mapping the Critical Links between Organizational Culture and TQM/Six Sigma Practices.« International Journal of Production Economics I23: 86Io6.

Weske, Mathias. 201 2. Business Process Management. Concepts, Languages, Architectures. Berlin: Springer-Verlag.

Wieland, Uwe, Marco Fischer, Marcus Pfitzner in Andreas Hilbert. 2015. $\gg$ Process Performance Measurement System - Towards a Customer-Oriented Solution.«Business Process Management 2 I (2): 3 I 2-3 I.

Willaert, Peter, Joachim Van der Bergh, Jurgen Willems in Dirk Deschoolmeester. 2007. »The Process-Oriented Organisation: A Holistic View. Developing a Framework for Business Process Orientation Maturity.« V Business Process Management. sth Interantional Conference, BPM 2007. Proceedings, ur. Gustavo Alonso, Peter Dadam in Michael Rosemann, I-I5. Heidelberg: Springer.

Wiklund, Håkan, in Pia Sandvik Wiklund. 2002. »Widening the Six Sigma Concept: An Approach to Improve Organizational Learning.« Total Quality Management I3 (2): 233-39.

Womack, James P., in Daniel T. Jones. 1996. Lean Thinking, New York: Free Press. 
Womack, James P., in Daniel T. Jones. 2003. Lean Thinking: Banish Waste and Create Wealth in Your Corporation. New York: Free Press.

\section{Viri}

Agencija za energijo. 2015a. »Letno poročilo Agencije za energijo za leto 2014.《 http://www.agen-rs.si/gradiva/-/asset_publisher/M2 $\mathrm{GdU}_{2 j} \mathrm{RtCxV/content/}$ letna-porocila-agencije-za-energijo?_IOI_INSTANCE_M $2 \mathrm{GdU}_{2 j} \mathrm{RtCxV}_{-}$ redirect $=\% 2$ Fgradiva.

Agencija za energijo. 2015b. »Akt o pravilih monitoringa kakovosti oskrbe z električno energijo.« http://www.uradni-list.si/files/RS_-2015-059००००4-OB Pooı-0०००.PDF\#!/pdf.

Agencija za energijo. 2016. »Udeleženci na trgu z električno energijo.« http:// www.agen-rs.si/udelezenci-na-trgu-z-elektricno-energijo.

AJPES (Agencija Republike Slovenije za javnopravne evidence in storitve). 2016. http://www.ajpes.si/Letna_porocila.

AUKN (Agencija za upravljanje kapitalskih naložb Republike Slovenije). 2012. \Priporocila in pričakovanja agencije za upravljanje kapitalskih naložb do družb z lastništvom države.« http://www.so-druzba.si/doc/Pravni_ akti/I_Pricakovanja_AUKN_oblikovana_verzija_2I_I2_20I2.pdf.

Borzen. 2016. »Predstavitev družbe.« https://www.borzen.si/sl/Domov/ menui /Družba-Borzen/O-družbi-Borzen.

Carli, Radko. 2015. »Sodobno in dobro vzdrževano elektroenergetsko omrežje za razvoj slovenskega gospodarstva. Razvoj, gradnja, obratovanje in vzdrževanje distribucijskega elektroenergetskega omrežja.« V Strateška konferenca elektrodistribucije Slovenije 20I5, ur. Roman Ponebšek I3-I6. Ljubljana: GIZ distribucije električne energije.

Elektro Gorenjska. 2015. »Letno poročilo družbe Elektro Gorenjska, d. d. za leto 20I4.《https://www.ajpes.si/jolp/podjetje.asp?maticna $=5175348000$.

ELES. 2015. »Letno poročilo 20I4.« http://www.eles.si/files/eles/userfiles/ SLO/O_Elesu/Letna_porocila/Eles_Letno_porocilo_2014_SLO.pdf.

EnKlikAnketa. https://www.rka.si/.

Gorenc, Jože. 20I5. Stroškovna učinkovitost prinaša poslovne uspehe. Pametna politika upravljanja podjetij za distribucijo električne energije omogoča nadaljnji razvoj slovenskega gospodarstva - ustvarjen dobiček naj se nameni investicijam v omrežje. V Strateška konferenca elektrodistribucije Slovenije 20Is, ur. Roman Ponebšek 7-I I. Ljubljana: GIZ distribucije električne energije. 
GEN. 20I5. »Oblikujemo trajnostno energetsko prihodnost Slovenije. Letno poročilo družbe in skupine GEN za leto 20I4.« http://www.gen-energija.si/files/ materials/ı/pdf/GEN_letno_slo_2or4_splet.pdf.

HSE. 2015. »Letno poročilo družbe in skupine 2014.« http://www.hse.si/si/files/ default/letna-porocila/HSE_letno\%2oporocilo\%202014\%20SLO_web.pdf.

Ponebšek, Roman. 2015. »Življenje brez elektrike si zelo težko predstavljamo.« V Strateška konferenca elektrodistribucije Slovenije 20Is, ur. Roman Ponebšek, 3. Ljubljana: GIZ distribucije električne energije.

Republika Slovenija Ministrstvo za infrastrukturo. 2015a. »Poročilo o stanju na področju energetike v Sloveniji v letu 20I4.《 http://www.energetika-portal. si/dokumenti/poslovna-porocila/porocilo-o-stanju-na-podrocju-energetike/.

Republika Slovenija Ministrstvo za infrastrukturo. 2015b. »Poslovanje družb elektrogospodarstva in premogovništva v letu 2014.« http://www.energetika-portal.si/dokumenti/poslovna-porocila/porocilo-o-stanju-na-podrocju-energetike/. 



\section{Priloge}

Priloga I Vprašalnik Raziskava zrelosti procesne usmerjenosti

Priloga $2 \quad$ Faktorske analize

Priloga 3 Regresijska analiza

Priloga $4 \quad$ Primerjava zrelosti procesne usmerjenosti in poslovne uspešnosti elektrodistribucijskih organizacij 


\section{Vprašalnik}

\section{Zrelost procesne usmerjenosti}

Kratko ime ankete: Zrelost procesne usmerjenosti

Število vprašanj: 21

Anketa je zaključena.

Aktivna od: 19.02.2016

Aktivna do: 23.3.2016

Avtor: rajko

Spreminjal: rajko

Dne: 07.02.2016

Dne: 09.04.2016

Opis:

\section{Q1 - I. STRATEŠKI VIDIK}

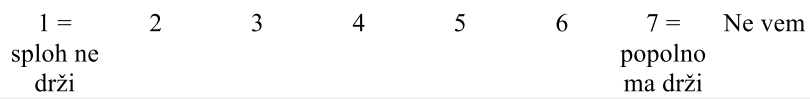

Vodstvo organizacije je aktivno vključeno $\mathrm{v}$ izboljševanje in prenove poslovnih procesov.

Cilji poslovnih procesov izhajajo iz strateških ciljev organizacije.

$\mathrm{Na}$ kolegijih na vseh nivojih vodenja se pogosto pogovarjamo o izboljševanju in prenovah poslovnih procesov.

Zaposleni na vseh nivojih so dobro seznanjeni s strateškimi

cilji.

Načrti za izboljšave glavnih procesov obstajajo ter so narejeni na podlagi izpolnjevanja pričakovanj odjemalcev, drugih relevantnih deležnikov in strategije.

\section{Q2 - II. OPREDELJENOST IN DOKUMENTIRANJE PROCESOV}

$1=$
$\begin{gathered}\text { sploh ne } \\ \text { drži }\end{gathered}$

V naši organizaciji so definirani glavni in podporni poslovni procesi. 
Q3 - Koliko glavnih procesov je v vaši organizaciji?

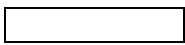

Q4 - Koliko podpornih procesov je v vaši organizaciji?

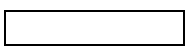

Q5 -

$\begin{array}{ccccccc}1= & 2 & 3 & 4 & 5 & 6 & \begin{array}{c}7= \\ \text { popolno } \\ \text { sploh ne } \\ \text { drži }\end{array} \\ \text { ma drži }\end{array}$

Procesi so dokumentirani $\mathrm{z}$ jasno opredeljenimi vhodi in izhodi.

Naloge in odgovornosti zaposlenih pri izvajanju procesov so jasno definirane in dokumentirane.

Poslovni procesi so definirani tako, da večina zaposlenih razume, kako potekajo.

Opisi (modeli) poslovnih procesov so dostopni vsem zaposlenim.

Uporabljamo uveljavljene sodobne me tode za opisovanje poslovnih procesov.

\section{Q6 - III. MERJENJE IN MENEDŽMENT PROCESOV}

\begin{tabular}{|c|c|c|c|c|c|c|c|c|}
\hline & $\begin{array}{c}1= \\
\text { sploh ne } \\
\text { drži }\end{array}$ & 2 & 3 & 4 & 5 & 6 & $\begin{array}{c}7= \\
\text { popolno } \\
\text { ma drži }\end{array}$ & $\mathrm{Ne}$ vem \\
\hline $\begin{array}{l}\text { Kazalniki procesov so } \\
\text { definirani in } \\
\text { dokumentirani. }\end{array}$ & O & O & C & $\Omega$ & 0 & & D & \\
\hline $\begin{array}{l}\text { V organizaciji merimo } \\
\text { uspešnost in učinkovitost } \\
\text { poslovnih procesov. }\end{array}$ & D & & & $\cap$ & 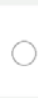 & & ) & \\
\hline $\begin{array}{l}\text { Postavljeni so konkretni } \\
\text { cilji za posamezne } \\
\text { kazalnike procesa. }\end{array}$ & ) & & & & & & & \\
\hline $\begin{array}{l}\text { O rezultatih kazalnikov } \\
\text { in doseganju ciljnih } \\
\text { vrednosti so zaposleni } \\
\text { redno obveščeni. }\end{array}$ & $D$ & & & & & & 8 & \\
\hline $\begin{array}{l}\text { Rezultati merjenj služijo } \\
\text { za postavljanje ciljev za } \\
\text { izboljšave procesov. }\end{array}$ & 0 & & & & & & $C$ & \\
\hline
\end{tabular}




$\begin{array}{ccccccc}1= & 2 & 3 & 4 & 5 & 6 & \begin{array}{c}7= \\ \text { popolno } \\ \text { sploh ne } \\ \text { drži }\end{array} \\ & & & & & \text { Nem vem }\end{array}$

Procese izboljšujemo

skozi formalne postopke.

Zaposleni so seznanjeni s spremembami v procesih.

\section{Q7 - IV. PROCESNA ORGANIZACIJSKA STRUKTURA}

$\begin{array}{ccccccc}1= & 2 & 3 & 4 & 5 & 6 & \begin{array}{c}7= \\ \text { popolno } \\ \text { ma drži } \\ \text { drži ne }\end{array} \\ & & & & & & \text { mem }\end{array}$

Delovna mesta zahtevajo opravljanje širokega spektra različnih nalog (večopravilnost).

Organizacijska struktura podpira nemoteno izvajanje procesov skozi poslovne funkcije (področja, sektorje, službe, oddelke).

Zaposleni pogosto delajo v skupinah, ki jih sestavljajo predstavniki različnih organizacijskih enot.

Vzpostavljeno je nedvoumno lastništvo poslovnih procesov. Direktorji poslovnih funkcij so v vodstveni hierarhiji pozicionirani višje od lastnikov procesov.

Q8 - Kakšen je položaj najvišje rangiranega zaposlenega, odgovornega za procese? Označite ustrezen odgovor:

je član najvišjega vodstva organizacije.

je neposredno podrejen najvišjemu vodstvu.

je posredno podrejen najvišjemu vodstvu.

nimamo ga.

Q9 - V organizaciji imamo posebno organizacijsko enoto ali del organizacijske enote, ki lastnikom procesov zagotavlja strokovno podporo pri dokumentiranju, spremljanju kazalnikov in izboljševanju procesov. Označite ustrezen odgovor:

DA

$\mathrm{NE}$

Q10 - V. UPRAVLJANJE Z ZAPOSLENIMI 


\begin{tabular}{|c|c|c|c|c|c|c|c|c|}
\hline & $\begin{array}{c}1= \\
\text { sploh ne } \\
\text { drži }\end{array}$ & 2 & 3 & 4 & 5 & 6 & $\begin{array}{c}7= \\
\text { popolno } \\
\text { ma drži }\end{array}$ & $\mathrm{Ne}$ vem \\
\hline $\begin{array}{l}\text { Zaposleni se neprestano } \\
\text { učijo. }\end{array}$ & 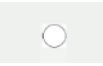 & & & & C & O & 0 & \\
\hline $\begin{array}{l}\text { Zaposleni poznajo } \\
\text { metode in tehnike } \\
\text { izboljševanja poslovnih } \\
\text { procesov. }\end{array}$ & O & & & 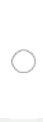 & 0 & 0 & 0 & \\
\hline $\begin{array}{l}\text { Pred uvedbo } \\
\text { spremenjenega načina } \\
\text { izvajanja poslovnih } \\
\text { procesov zaposlene } \\
\text { dobro seznanimo s } \\
\text { spremembami. }\end{array}$ & & & & & & & $C$ & \\
\hline $\begin{array}{l}\text { Zaposleni so odgovorni } \\
\text { za doseganje ciljev } \\
\text { poslovnih procesov. }\end{array}$ & O & D & D & 0 & 0 & 0 & 0 & $\mathrm{O}$ \\
\hline $\begin{array}{l}\text { Zaposleni so stimulirani } \\
\text { za predloge izboljšav } \\
\text { procesov. }\end{array}$ & O & & & & ( & & ( & \\
\hline
\end{tabular}

\section{Q11 - VI. PROCESNA ORGANIZACIJSKA KULTURA}

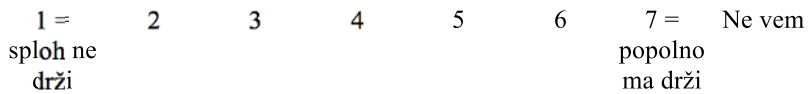

V organizaciji se pogosto uporabljajo izrazi kot so proces, vhod procesa, izhod

(rezultat) procesa, lastnik oz. skrbnik procesa, kazalniki procesa, cilji procesa.

Povprečni zaposleni razume delovanje organizacije kot niz povezanih procesov.

Ko se srečajo zaposleni iz različnih organizacijskih enot, je pogosto prisotna

napetost pri

komunikaciji.

Zaposleni iz

različnih organizacijskih

enot imajo občutek, da

so njihovi cilji med seboj

usklajeni.

Vodje različnih

organizacijskih enot se pogosto sestajajo zaradi usklajevanja aktivnosti med organizaciiskimi 


$\begin{array}{ccccccc}1= & 2 & 3 & 4 & 5 & 6 & \begin{array}{c}7= \\ \text { popolno } \\ \text { ma drži }\end{array} \\ \begin{array}{c}\text { sploh ne } \\ \text { drži }\end{array} & & & & & & \text { Nem }\end{array}$

enotami.

Zaposleni iz

različnih organizacijskih

enot se med seboj

posvetujejo, kadar je to

potrebno.

\section{Q12 - VII. TRŽNA USMERJENOST}

$\begin{array}{ccccccc}1= & 2 & 3 & 4 & 5 & 6 & \begin{array}{c}7= \\ \text { popolno } \\ \text { ma drži }\end{array} \\ \begin{array}{c}\text { sploh ne } \\ \text { drži }\end{array} & & & & & \text { Nem }\end{array}$

Potrebe odjemalcev (oz.

kupcev, uporabnikov)

sistematično spremljamo

in analiziramo.

Zaposleni dobro

odjemalcev.

Odzive odjemalcev

spremljamo in

uporabljamo pri

izboljševanju procesov.

Zadovoljstvo

odjemalcev merimo

redno in sistematično.

Storitve organizacije so

osnovane na podlagi

potreb in pričakovanj

odjemalcev.

Spremljamo delovanje podobnih organizacij

doma in $\mathrm{v}$ tujini.

$\mathrm{Na}$ spremembe zahtev

trga $\mathrm{z}$ električno energijo

se hitro odzovemo.

\section{Q13 - VIII. VIDIK DOBAVITELJEV (POSLOVNIH PARTNERJEV)}

$\begin{array}{ccccccc}1= & 2 & 3 & 4 & 5 & 6 & \begin{array}{c}7= \\ \text { popolno } \\ \text { ma drži }\end{array} \\ \text { drži ne vem } & & & & & & \\ \end{array}$

Vzpostavljene imamo dolgoročne pogodbe s ključnimi dobavitelji.

$\mathrm{Z}$ dobavitelji tesno sodelujemo in se povezujemo na ravni procesov.

O spremembah naših procesov dobavitelje formalnn nhvectimn 
Q14 - IX. PROCESNA INFORMACIJSKA TEHNOLOGIJA

$\begin{array}{ccccccc}1= & 2 & 3 & 4 & 5 & 6 & \begin{array}{c}7= \\ \text { popolno } \\ \text { mploh ne } \\ \text { drži }\end{array}\end{array}$

Informatizacija

poslovanja temelji na procesih (ne na

poslovnih funkcijah).

Naš informacijski sistem vodstvu zagotavlja

relevantne informacije o uspešnosti in učinkovitosti procesov.

Naš informacijski sistem je fleksibilen in podpira spreminjanje procesov. Uporabljamo posebna orodja za menedžment odnosov z

odjemalci (CRM).

Uporabljamo možnosti

elektronskega

povezovanja s

poslovnimi partnerji.

V organizaciji

uporabljamo

specializirana orodja za

menedžment poslovnih

procesov (omogočajo

modeliranje,

avtomatizacijo,

izvajanje, spremljanje

poslovnih procesov).

\section{Q15 - PROCESNA USMERJENOST}

$\begin{array}{lccccccc} & \begin{array}{c}1= \\ \text { sploh ne } \\ \text { drži }\end{array} & 2 & 3 & 4 & 5 & 6 & \begin{array}{c}7= \\ \text { popolno } \\ \text { ma drži }\end{array} \\ \begin{array}{l}\text { Naša organizacija je zelo } \\ \text { procesno usmerjena. }\end{array} & 0 & 0 & & & & & \\ \begin{array}{l}\text { Uspešno in učinkovito } \\ \text { upravljanje poslovnih } \\ \text { procesov je } \\ \text { naša prednost. }\end{array}\end{array}$

\section{Q16 - Označite vašo raven v hierarhiji vodenja:}

Predsednik uprave ali generalni direktor oz. direktor družbe, član uprave, pomočnik predsednika uprave oziroma direktorja družbe

Direktor oziroma izvršni direktor organizacijske enote (področja, sektorja)

Vodja službe, vodja enote, vodja oddelka, vodja projekta 
Merjenje zrelosti procesne usmerjenosti

Q17 - Označite vaše delovne izkušnje (delovno dobo) v letih:

do 10 let

nad 10 do 30 let

nad 30 let

Q18 - Označite prosim organizacijo, v kateri delate:

Skupina GEN

Holding Slovenske elektrarne

Energetika Ljubljana, enota TE-TOL

ELES

Elektrodistribucijsko podjetje

Informatika

I72 IF (1) Q18 = [1]

Q19 - Vaša organizacija v skupini GEN:

Gen energija

Nuklearna elektrarna Krško

Savske elektrarne Ljubljana

Termoelektrarna Brestanica

Hidroelektrarne na Spodnji Savi

IF (2) $\mathrm{Q} 18=[2]$

Q20 - Vaša organizacija v skupini HSE:

Holding Slovenske elektrarne

Dravske elektrarne Maribor

Soške elektrarne Nova Gorica

Termoelektrarna Šoštanj

Premogovnik Velenje

HSE Invest

IF (3) $\mathrm{Q} 18=[5]$

Q21 - Vaše elektrodistribucijsko podjetje:
Elektro Celje
Elektro Gorenjska
Elektro Ljubljana
Elektro Maribor
Elektro Primorska 


\section{Strateški vidik}

\section{Factor Analysis}

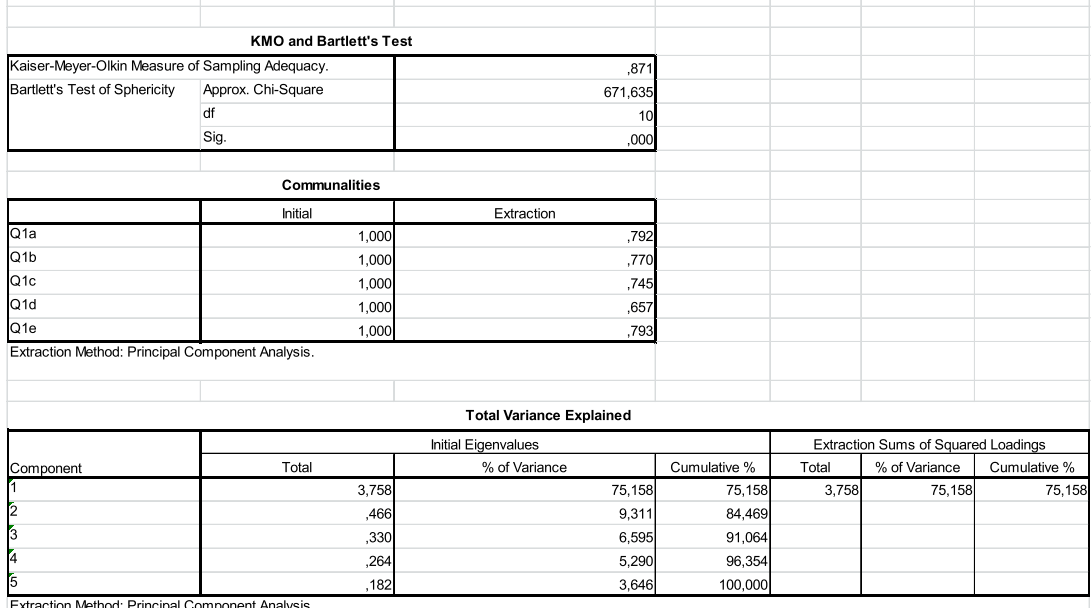
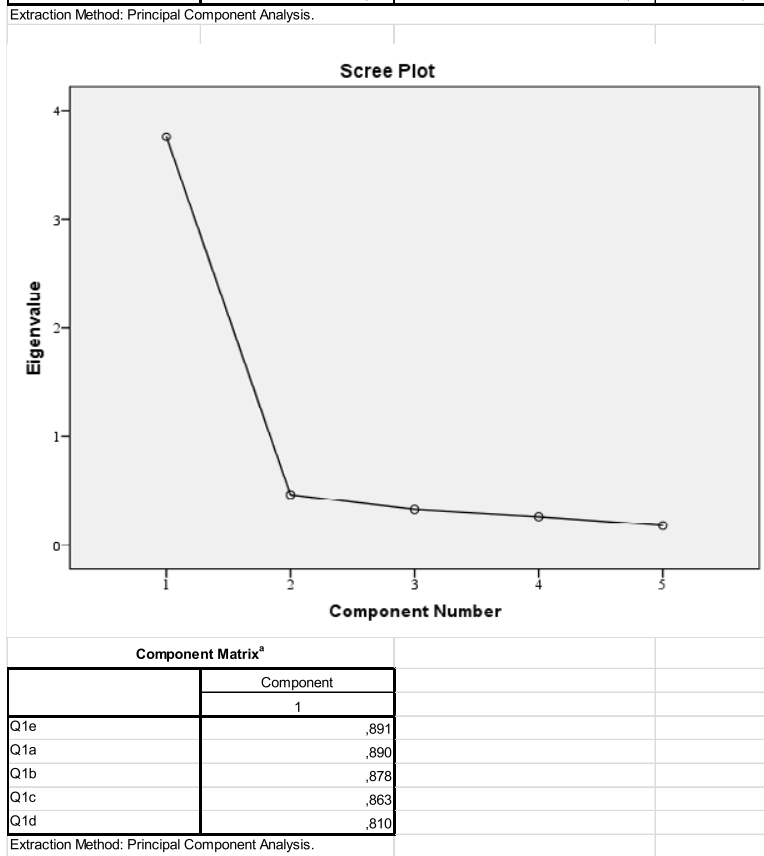

COMPUTE STRATEŠKI_VIDIK $=(21 \mathrm{a}+Q 1 \mathrm{~b}+Q 1 \mathrm{c}+21 \mathrm{~d}+Q 1 \mathrm{e}) / 5$. EXECUTE. 


\section{Opredeljenost in dokumentiranje procesov}

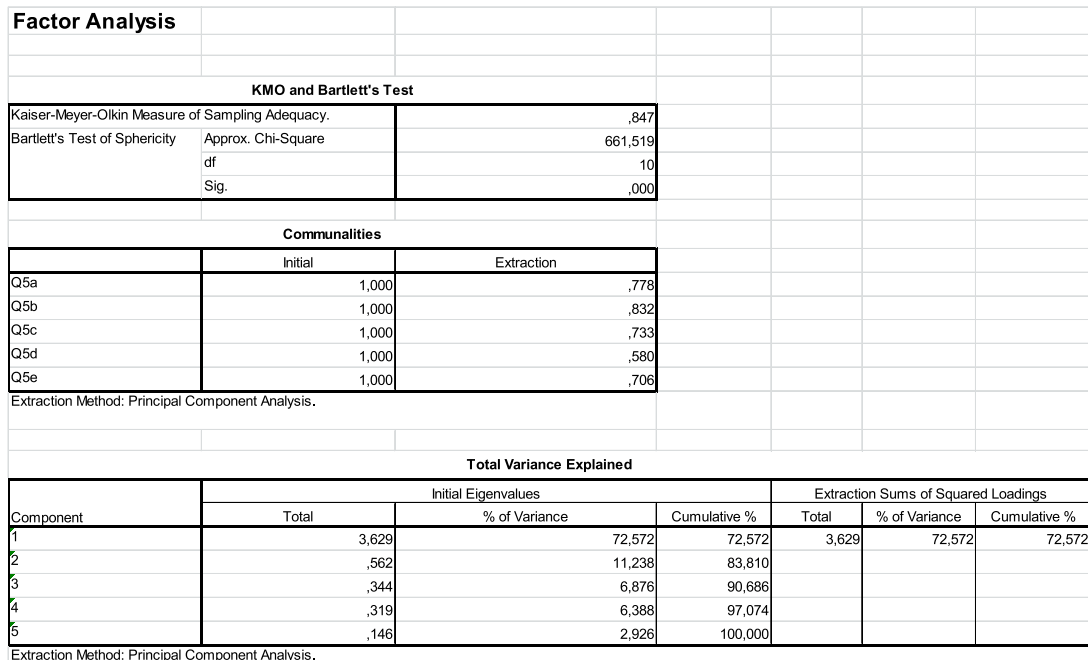

Scree Plot

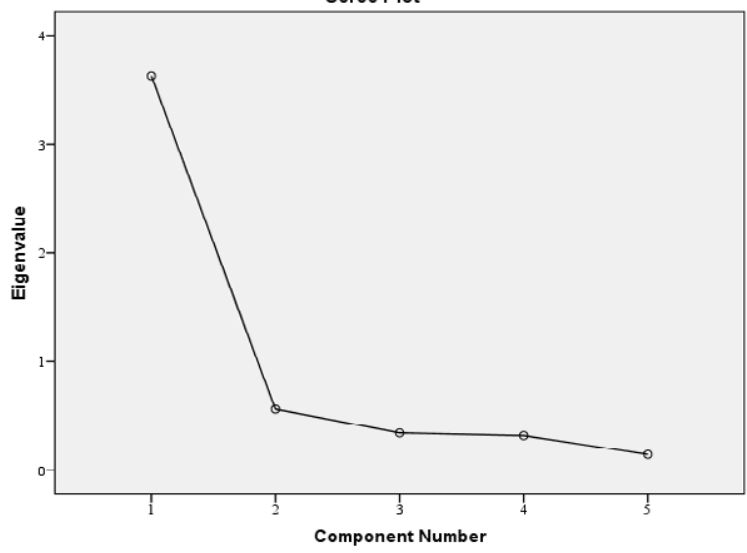

Component Matrix ${ }^{\mathrm{a}}$

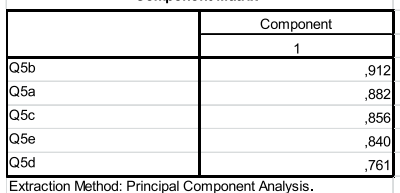

Extraction Method: Principal Component Analysis

COMPUTE ORREDELJENOST $=(25 a+Q 5 b+Q 5 c+Q 5 d+Q 5 e) / 5$.

EXECUTE. 


\section{Merjenje in management procesov}

\begin{tabular}{|c|c|c|}
\hline \multicolumn{3}{|l|}{ Factor Analysis } \\
\hline \multicolumn{3}{|c|}{ KMO and Bartlett's Test } \\
\hline \multicolumn{2}{|c|}{ Kaiser-Meyer-Olkin Measure of Sampling Adequacy. } & 875 \\
\hline \multirow{3}{*}{ Bartlett's Test of Sphericity } & Approx. Chi-Square & 1264,505 \\
\hline & df & \\
\hline & Sig. & ,000 \\
\hline \multicolumn{3}{|c|}{ Communalities } \\
\hline & Initial & Extraction \\
\hline Q6a & 1,000 & .792 \\
\hline Q6b & 1,000 & .766 \\
\hline Q6c & 1,000 & ,815 \\
\hline Q6d & 1,000 & ,719 \\
\hline Q6e & 1,000 & 798 \\
\hline Q6f & 1,000 & .650 \\
\hline Q6g & 1,000 & .455 \\
\hline
\end{tabular}

Extraction Method: Principal Component Analysis.

Total Variance Explained

\begin{tabular}{|c|c|c|c|c|c|c|}
\hline \multirow[b]{2}{*}{ Component } & \multicolumn{3}{|c|}{ Initial Eigenvalues } & \multicolumn{3}{|c|}{ Extraction Sums of Squared Loadings } \\
\hline & Total & $\%$ of Variance & Cumulative $\%$ & Total & $\%$ of Variance & Cumulative $\%$ \\
\hline 1 & 4,996 & 71,378 & 71,378 & 4,996 & 71,378 & 71,378 \\
\hline 2 & ,736 & 10,516 & 81,894 & & & \\
\hline 3 &, 416 & 5,944 & 87,838 & & & \\
\hline 4 & ,337 & 4,817 & 92,655 & & & \\
\hline 5 & ,209 & 2,992 & 95,647 & & & \\
\hline 6 & ,167 & 2,390 & 98,036 & & & \\
\hline 7 & , 137 & 1,964 & 100,000 & & & \\
\hline
\end{tabular}
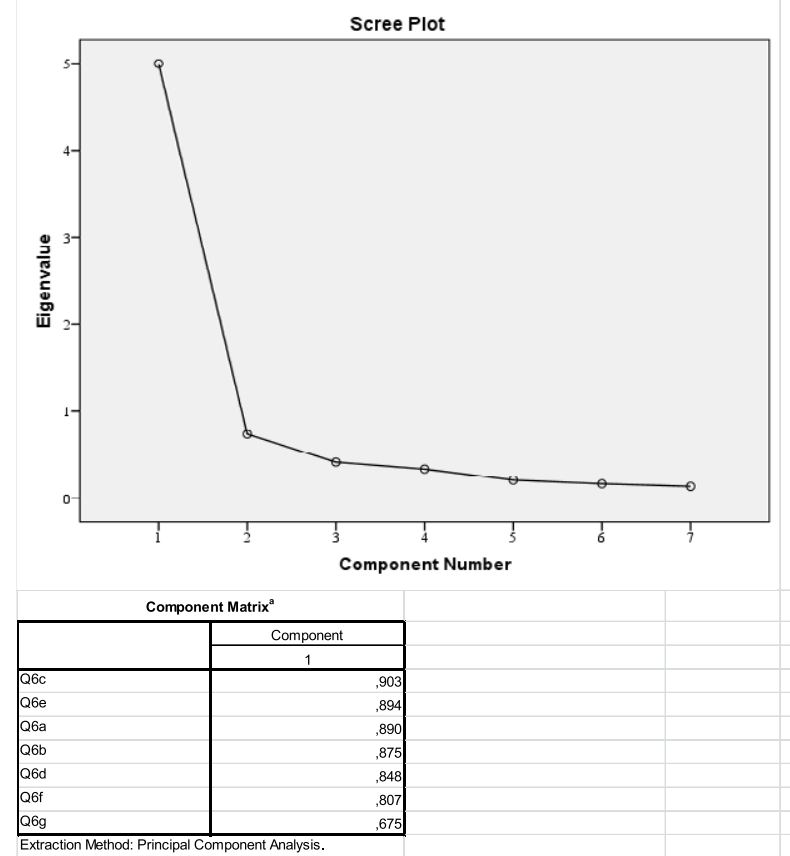

COMPUTE MERJENJE $=(26 \mathrm{a}+Q 6 \mathrm{~b}+Q 6 \mathrm{c}+Q 6 \mathrm{~d}+96 \mathrm{e}+Q 6 \mathrm{f}+96 \mathrm{~g}) / 7$. EXECUTE. 


\section{Procesna organizacijska struktura}
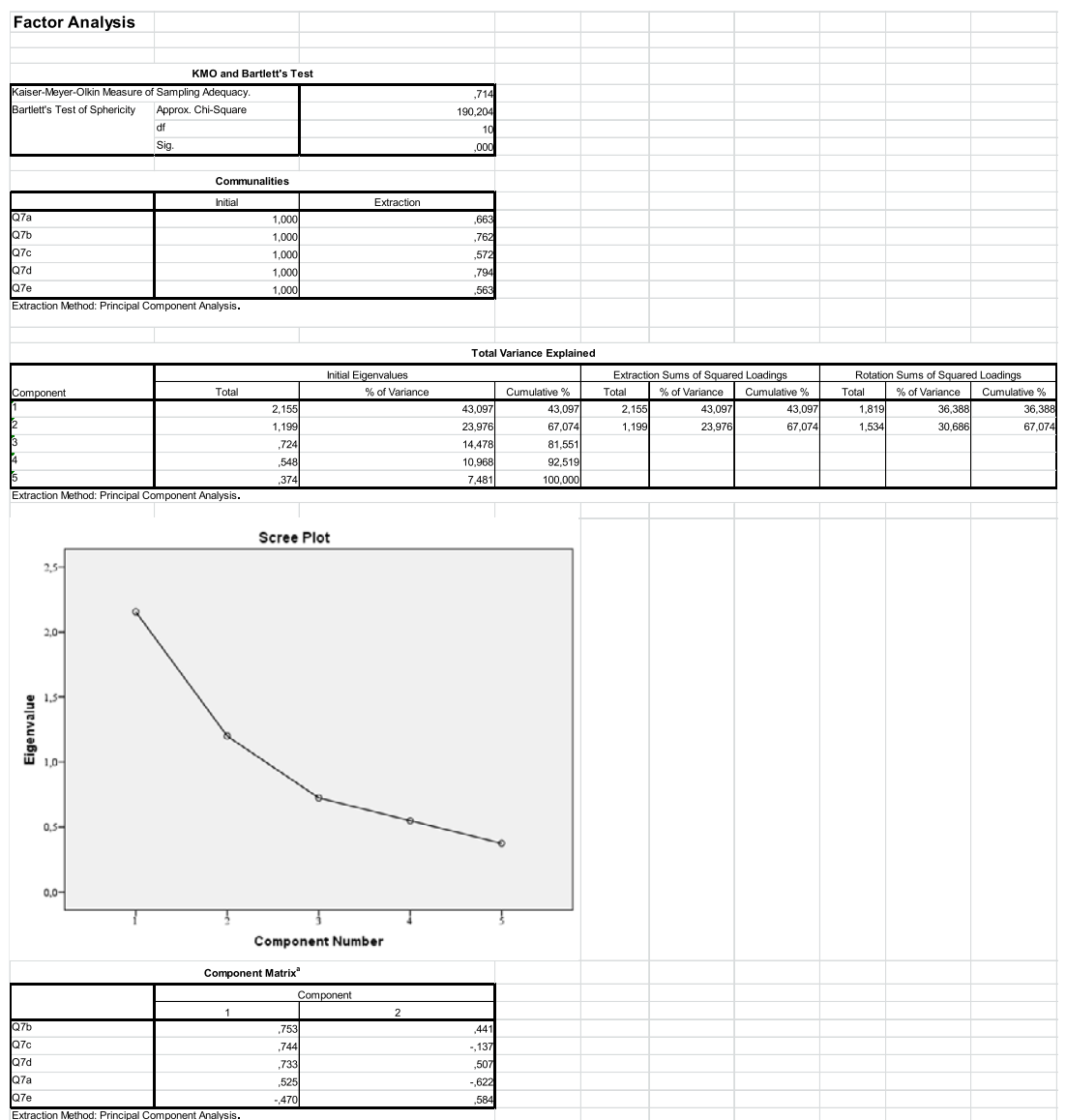

a. 2 components extracted.

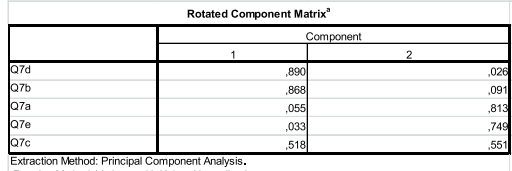

Extraction Method: Principal Component Analysis.
Rotation Method: Varimax with Kaiser Normalization

a. Rotation converged in 3 terations

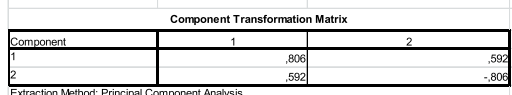

Rotation Method: Varimax with Kaiser Normalization.

COMPUTE STRUKTURAI $=(27 \mathrm{~d}+Q \mathbf{2 7 b}) / 2$.

EXECUTE.

(2)

exccout.

STRIKTURA $=((S T R U K T U R A 1 * 1.819)+($ STRUKTURA2 $* 1.534)) /(1.819+1.534)$ EXFCUTE. 


\section{Upravljanje z zaposlenimi}

\section{Factor Analysis}

KMO and Bartlett's Test

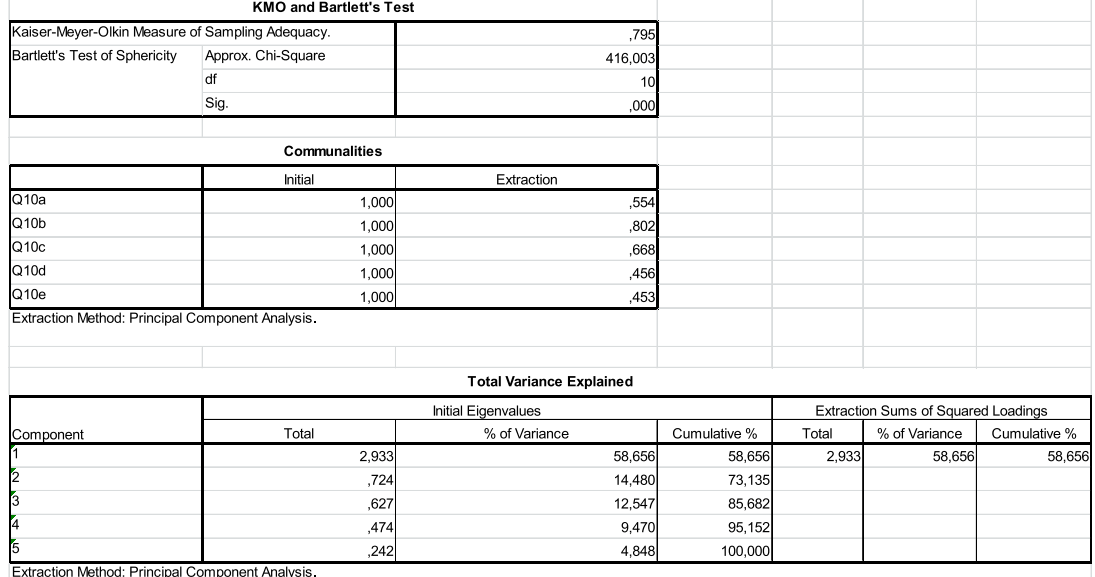

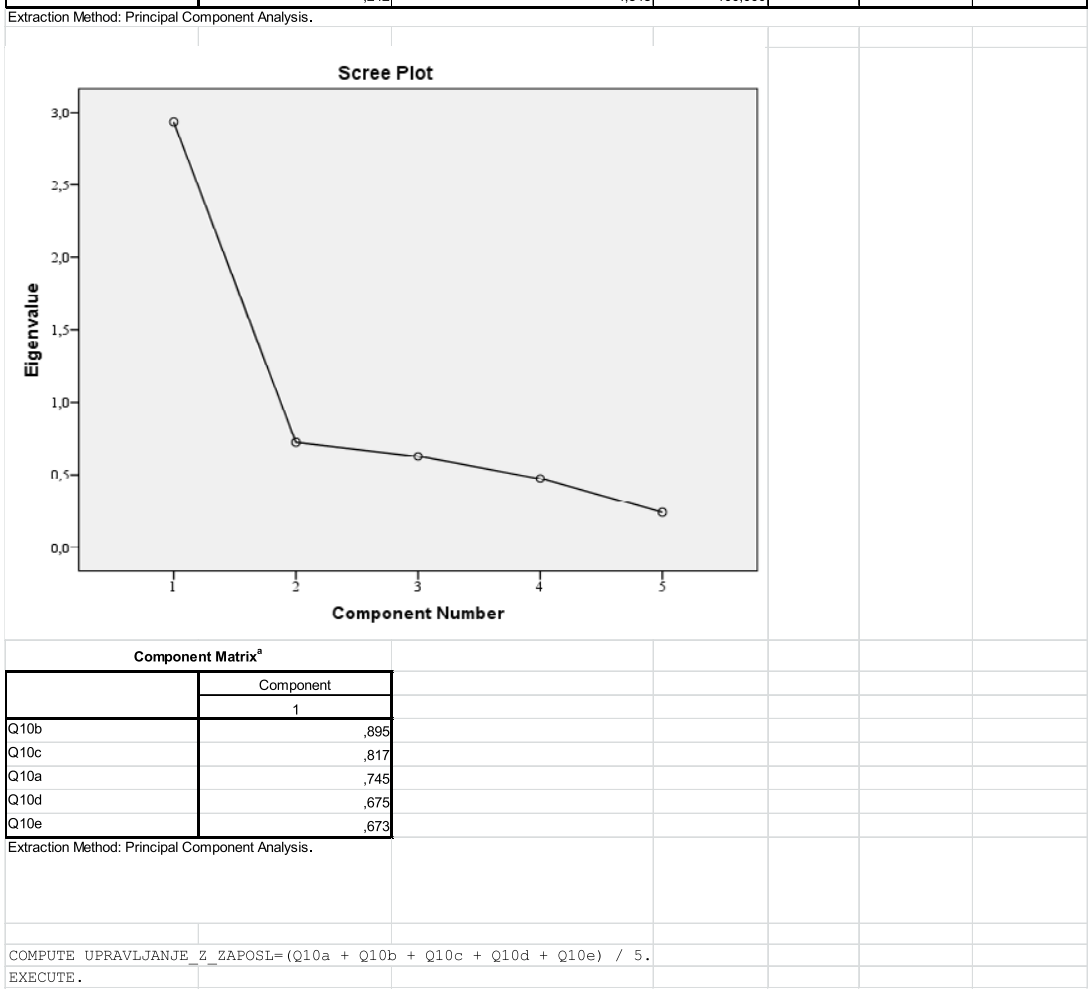




\section{Procesna organizacijska kultura}

Factor Analysis 1

KMO and Bartlett's Test

\begin{tabular}{|l|r|r|}
\hline Kaiser-Meyer-Olkin Measure of Sampling Adequacy. & 791 \\
Bartlett's Test of Sphericity & Approx. Chi-Square & 378,255 \\
& df & 15 \\
& Sig. &, 000 \\
\hline
\end{tabular}

Communalities

\begin{tabular}{|l|r|r|}
\hline & Initial & Extraction \\
\hline Q11a & 1,000 &, 429 \\
Q11b & 1,000 &, 583 \\
Q11c & 1,000 &, 024 \\
Q11d & 1,000 &, 644 \\
Q11e & 1,000 &, 601 \\
Q11f & 1,000 &, 659 \\
\hline
\end{tabular}

Extraction Method: Principal Component Analysis.

Total Variance Explained

\begin{tabular}{|c|c|c|c|c|c|c|}
\hline \multicolumn{7}{|c|}{ Total Variance Explained } \\
\hline \multirow[b]{2}{*}{ Component } & \multicolumn{3}{|c|}{ Initial Eigenvalues } & \multicolumn{3}{|c|}{ Extraction Sums of Squared Loadings } \\
\hline & Total & $\%$ of Variance & Cumulative $\%$ & Total & $\%$ of Variance & Cumulative $\%$ \\
\hline 1 & 2,941 & 49,014 & 49,014 & 2,941 & 49,014 & 49,014 \\
\hline 2 & 1,025 & 17,089 & 66,103 & & & \\
\hline 3 & ,762 & 12,703 & 78,806 & & & \\
\hline 4 &, 543 & 9,056 & 87,862 & & & \\
\hline 5 & ,378 & 6,305 & 94,167 & & & \\
\hline 6 & ,350 & 5,833 & 100,000 & & & \\
\hline
\end{tabular}

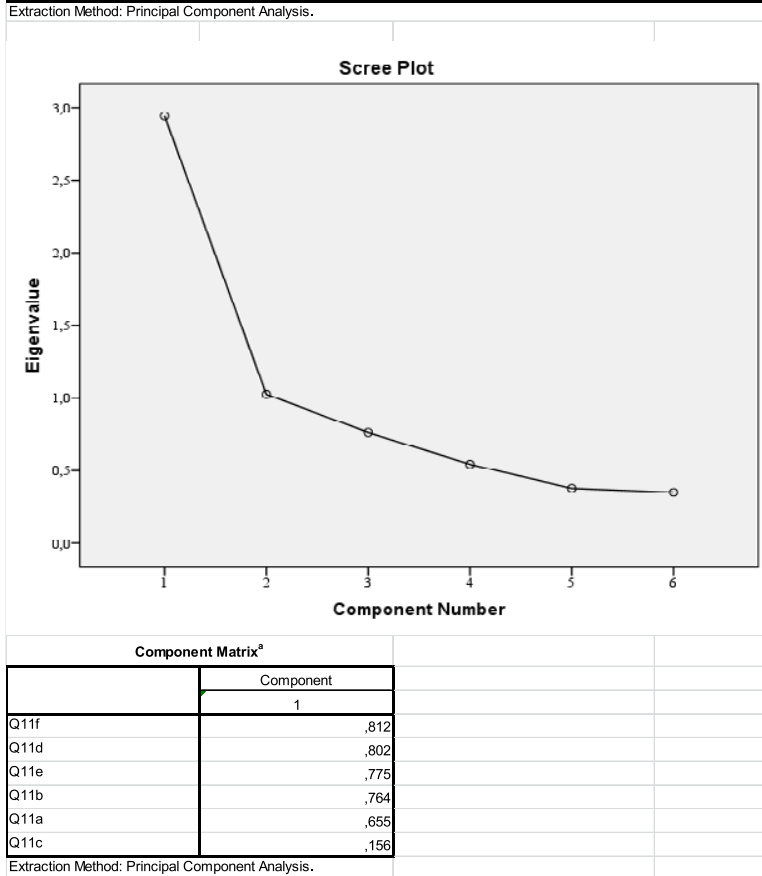


Factor Analysis 2

KMO and Bartlett's Test

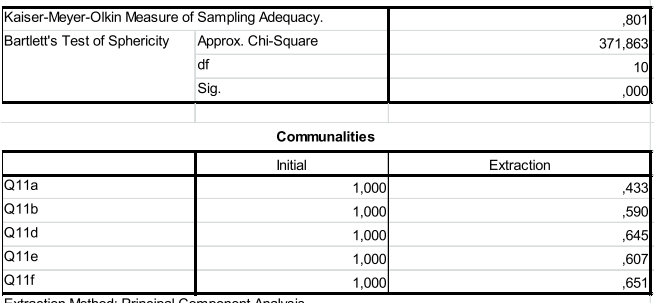

Extraction Method: Principal Component Analysis.

Total Variance Explained

\begin{tabular}{|c|c|c|c|c|c|c|}
\hline \multirow[b]{3}{*}{ Component } & \multicolumn{3}{|c|}{ Total Variance Explained } & \\
\hline & & igenvalues & & Extracti & $n$ Sums of Square & Loadings \\
\hline & Total & $\%$ of Variance & Cumulative $\%$ & Total & $\%$ of Variance & Cumulative $\%$ \\
\hline 1 & 2,927 & 58,536 & 58,536 & 2,927 & 58,536 & 58,536 \\
\hline 2 &, 788 & 15,769 & 74,305 & & & \\
\hline 3 & .543 & 10,852 & 85,157 & & & \\
\hline 4 &, 378 & 7,568 & 92,725 & & & \\
\hline 5 & .364 & 7,275 & 100,000 & & & \\
\hline
\end{tabular}

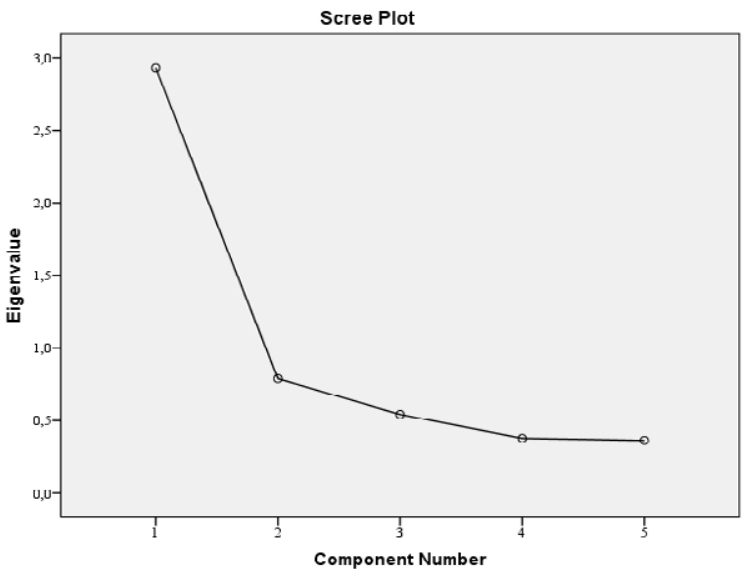

Component Matrix

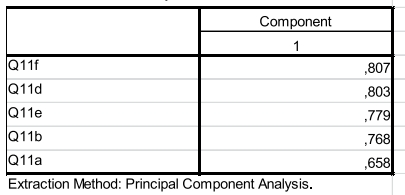

COMPUTE ORG_KULTURA $=(211 \mathrm{f}+Q 11 \mathrm{~d}+Q 11 \mathrm{e}+\mathrm{Q11b}+\mathrm{Q11a}) / 5$. EXECUTE. 


\section{Tržna usmerjenost}

\section{Factor Analysis}

\begin{tabular}{|l|r|r|}
\hline \multicolumn{2}{|c|}{ KMO and Bartlett's Test } \\
\hline Kaiser-Meyer-Olkin Measure of Sampling Adequacy. &, 882 \\
Bartlett's Test of Sphericity & Approx. Chi-Square & 938,171 \\
\cline { 2 - 3 } & df & 21 \\
\cline { 2 - 3 } & Sig. &, 000 \\
\hline
\end{tabular}

\begin{tabular}{|l|r|r|}
\hline \multicolumn{3}{|c|}{ Communalities } \\
\hline & Initial & Extraction \\
\hline Q12a & 1,000 &, 778 \\
\hline Q12b & 1,000 &, 681 \\
Q12c & 1,000 &, 816 \\
Q12d & 1,000 &, 718 \\
Q12e & 1,000 &, 765 \\
Q12f & 1,000 &, 483 \\
Q12g & 1,000 &, 554 \\
\hline
\end{tabular}

Total Variance Explained

\begin{tabular}{|c|c|c|c|c|c|c|}
\hline \multirow[b]{2}{*}{ Component } & \multicolumn{3}{|c|}{ Initial Eigenvalues } & \multicolumn{3}{|c|}{ Extraction Sums of Squared Loadings } \\
\hline & Total & $\%$ of Variance & Cumulative $\%$ & Total & $\%$ of Variance & Cumulative $\%$ \\
\hline 1 & 4,794 & 68,486 & 68,486 & 4,794 & 68,486 & 68,486 \\
\hline 2 & ,918 & 13,120 & 81,606 & & & \\
\hline 3 & ,361 & 5,163 & 86,769 & & & \\
\hline 4 & ,322 & 4,602 & 91,371 & & & \\
\hline 5 & ,275 & 3,929 & 95,300 & & & \\
\hline 6 & 188 & 2,689 & 97,989 & & & \\
\hline 7 & ,141 & 2,011 & 100,000 & & & \\
\hline
\end{tabular}

Scree Plot
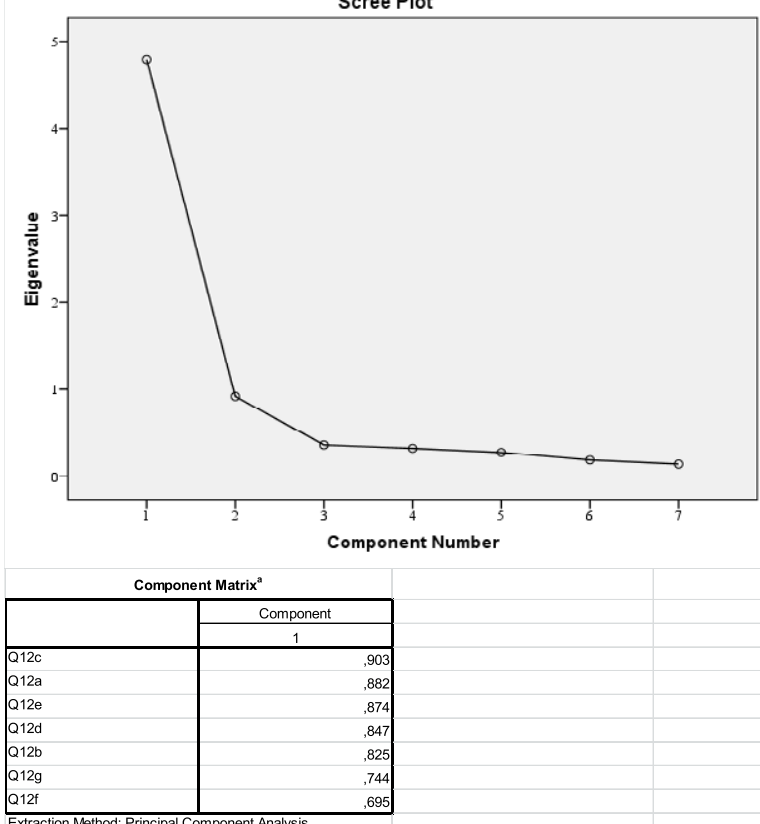

Extraction Method: Principal Component Analysis. 
Vidik (poslovnih partnerjev)

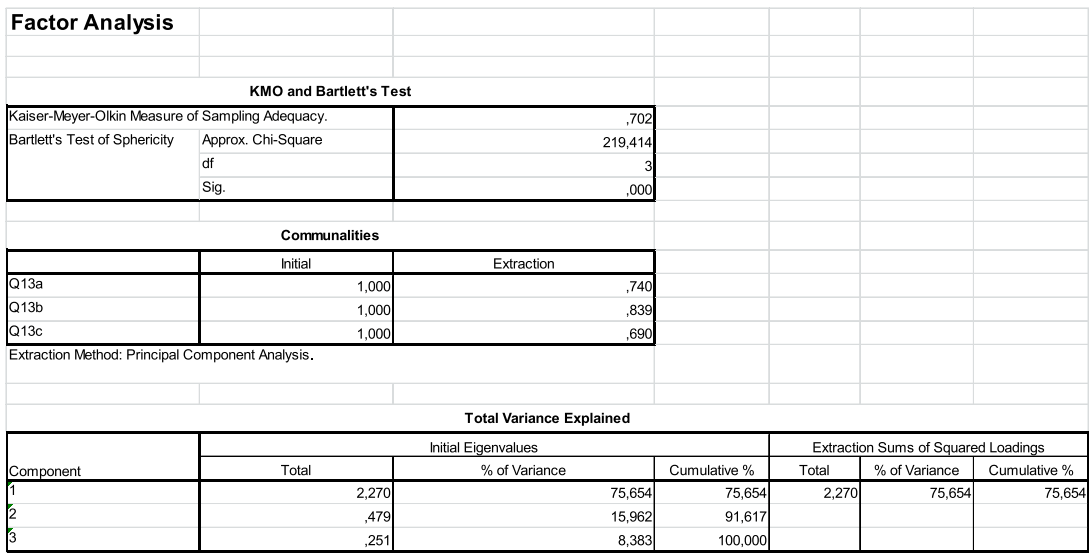

, 251
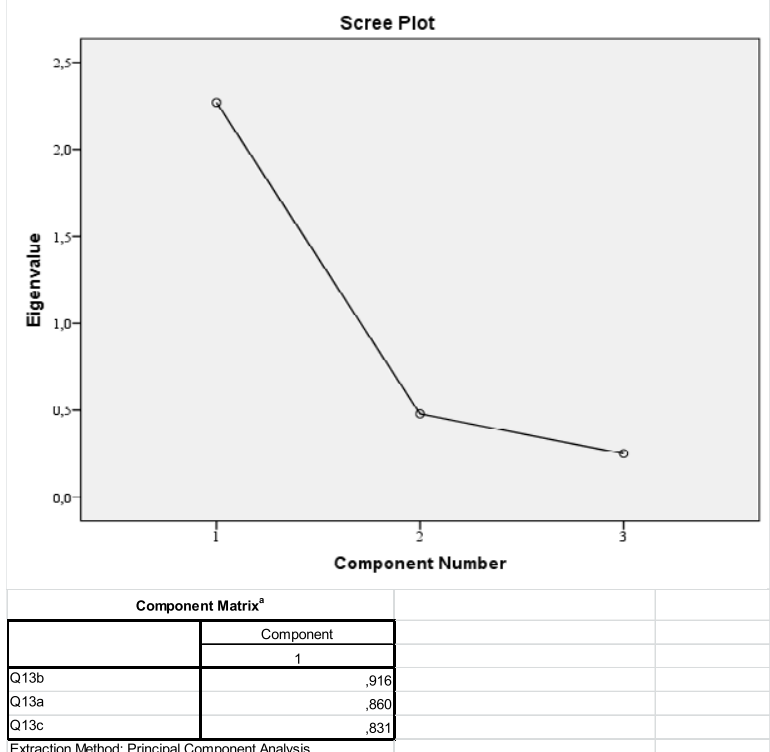

Extraction Method: Principal Component Analysis

COMPUTE VIDIK DOBAVITELJ $=(Q 13 a+Q 13 b+Q 13 c) / 3$.

EXECUTE. 


\section{Procesna informacijska tehnologija}

\section{Factor Analysis}

KMO and Bartlett's Test

\begin{tabular}{|ll|r|}
\hline Kaiser-Meyer-Olkin Measure of Sampling Adequacy. &, 830 \\
Bartlett's Test of Sphericity & Approx. Chi-Square & 351,405 \\
& df & 15 \\
& Sig. &, 000 \\
\hline
\end{tabular}

\begin{tabular}{|l|r|r|}
\multicolumn{3}{c|}{ Communalities } \\
\hline & Initial & Extraction \\
\hline Q14a & 1,000 &, 402 \\
Q14b & 1,000 &, 706 \\
Q14c & 1,000 &, 636 \\
Q14d & 1,000 &, 576 \\
Q14e & 1,000 &, 582 \\
\hline Q14f & 1,000 &, 513 \\
\hline
\end{tabular}

Extraction Method: Principal Component Analysis.

Total Variance Explained

\begin{tabular}{|c|c|c|c|c|c|c|}
\hline \multirow[b]{2}{*}{ Component } & \multicolumn{3}{|c|}{ Initial Eigenvalues } & \multicolumn{3}{|c|}{ Extraction Sums of Squared Loadings } \\
\hline & Total & $\%$ of Variance & Cumulative $\%$ & Total & $\%$ of Variance & Cumulative $\%$ \\
\hline 1 & 3,416 & 56,940 & 56,940 & 3,416 & 56,940 & 56,940 \\
\hline 2 & ,905 & 15,086 & 72,026 & & & \\
\hline 3 &, 557 & 9,282 & 81,308 & & & \\
\hline 4 & ,451 & 7,511 & 88,819 & & & \\
\hline 5 & ,397 & 6,608 & 95,427 & & & \\
\hline 6 & ,274 & 4,573 & 100,000 & & & \\
\hline
\end{tabular}

Extraction Method: Principal Component Analysis.
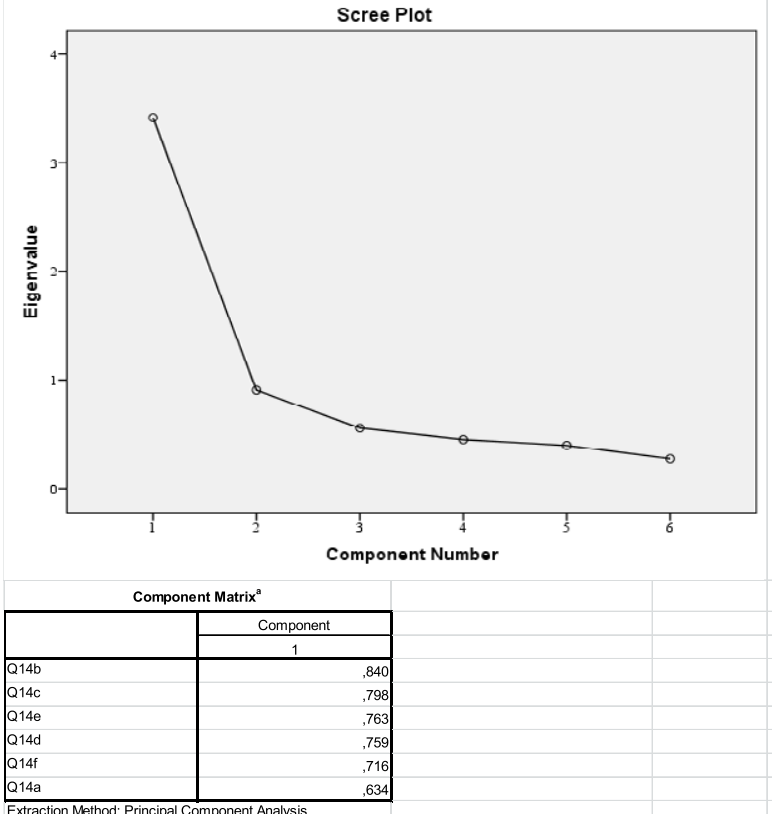

Extraction Method: Principal Component Analysis.

COMPUTE INFORMACIJSKA TEHNOLOGIJA $=(214 \mathrm{a}+Q 14 \mathrm{~b}+Q 14 \mathrm{c}+Q 14 \mathrm{~d}+Q 14 \mathrm{e}+Q 14 \mathrm{f}) / 6$. EXECUTE. 


\section{Regression}

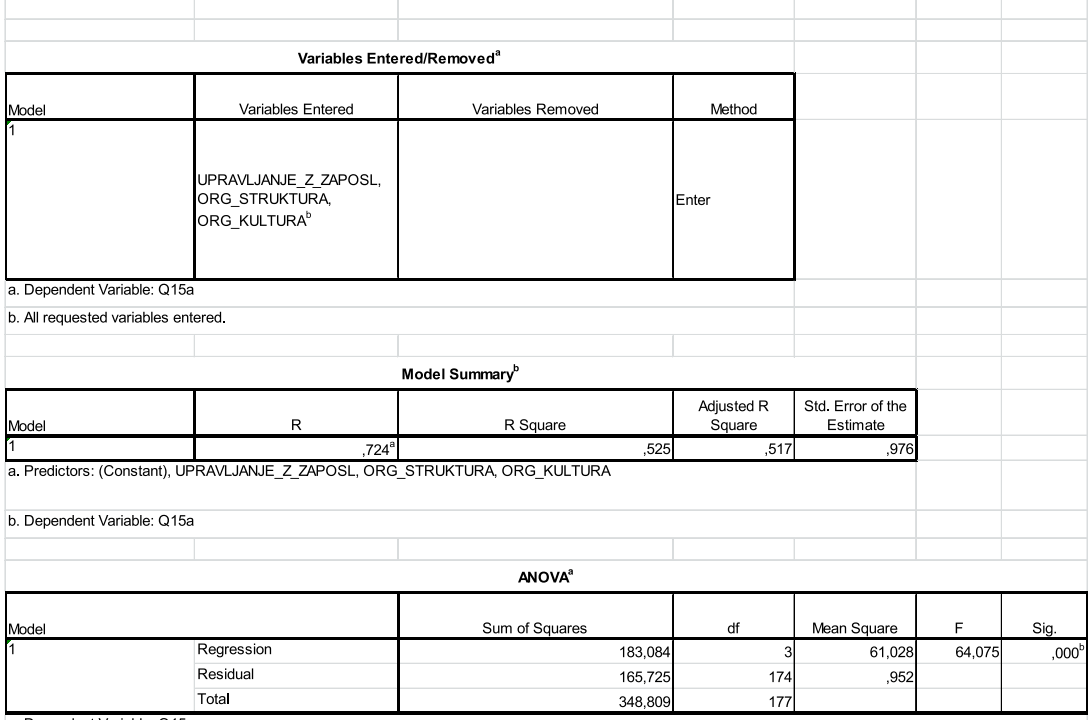

a. Dependent Variable: Q15a

b. Predictors: (Constant), UPRAVLJANJE_Z_ZAPOSL, ORG_STRUKTURA, ORG_KULTURA

Coefficients $^{\mathrm{a}}$

\begin{tabular}{|c|c|c|c|c|c|c|}
\hline \multirow[b]{2}{*}{ Model } & & \multicolumn{2}{|l|}{ Unstandardized Coefficients } & \multirow{2}{*}{$\begin{array}{c}\begin{array}{c}\text { Standardized } \\
\text { Coefficients }\end{array} \\
\text { Beta }\end{array}$} & \multirow[b]{2}{*}{$t$} & \multirow[b]{2}{*}{ Sig. } \\
\hline & & B & Std. Error & & & \\
\hline \multirow[t]{4}{*}{1} & (Constant) &,- 119 &, 396 & &,- 300 &, 765 \\
\hline & ORG_STRUKTURA &, 252 & ,121 & ,164 & 2,081 & ,039 \\
\hline & ORG_KULTURA & \begin{tabular}{c|c|}
.493 \\
\end{tabular} &, 112 & 391 & 4,419 & .000 \\
\hline & UPRAVLJANJE_Z_ZAPOSL & ,298 & ,114 & .236 & 2,616 & ,010 \\
\hline
\end{tabular}

a. Dependent Variable: Q15a

Residuals Statistics ${ }^{a}$

\begin{tabular}{|c|c|c|c|c|c|}
\hline \multicolumn{6}{|c|}{ Residuals Statistics $^{a}$} \\
\hline & Minimum & Maximum & Mean & Std. Deviation & $\mathrm{N}$ \\
\hline Predicted Value & 1,15 & 6,95 & 4,71 & 1,017 & 178 \\
\hline Residual & $-2,530$ & 2,820 & , 000 & .968 & 178 \\
\hline Std. Predicted Value & $-3,493$ & 2,205 &, 000 & 1,000 & 178 \\
\hline Std. Residual & $-2,592$ & 2,890 & .000 & ,991 & 178 \\
\hline
\end{tabular}

a. Dependent Variable: Q15a 


\section{Charts}
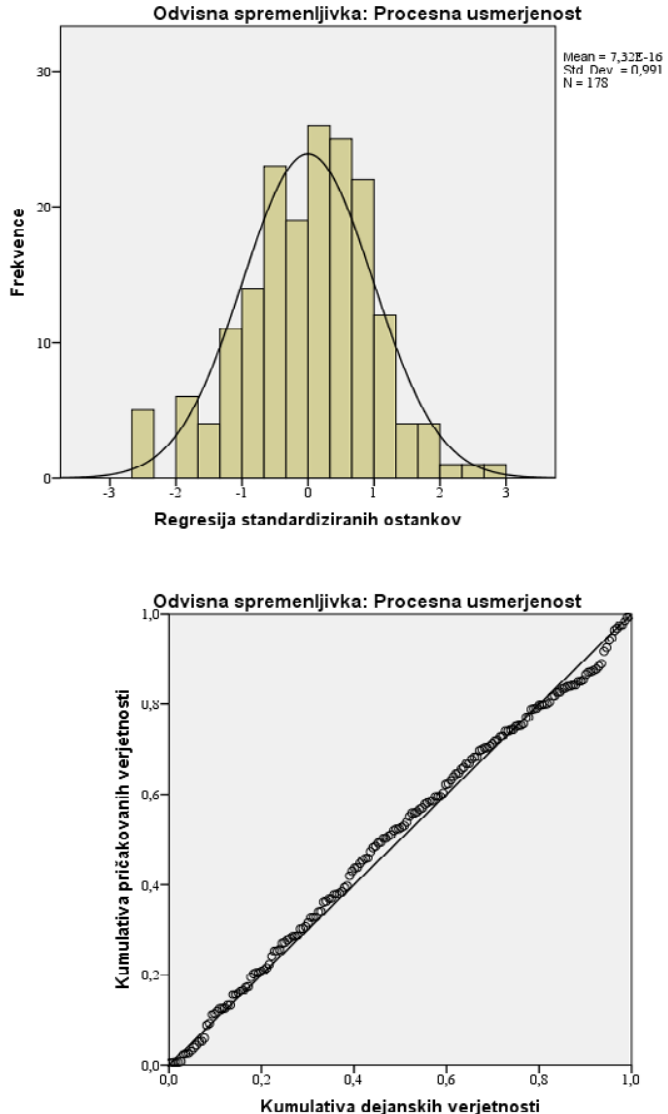

Scatterplot

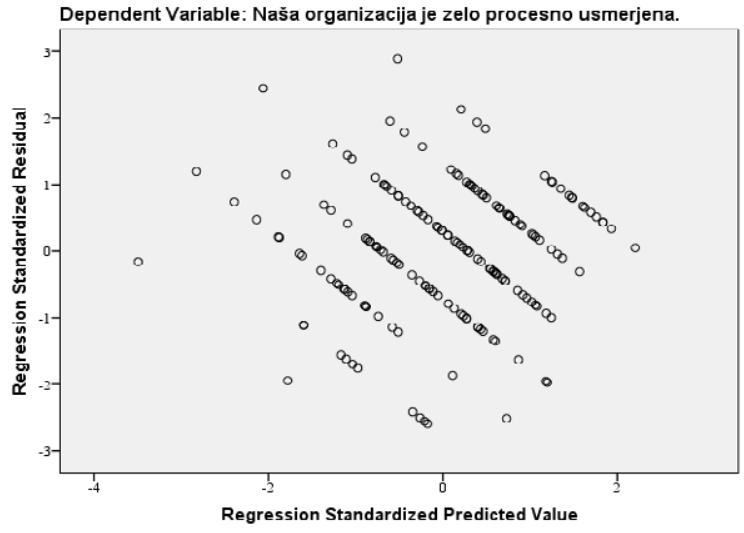




\section{Rangiranje rezultatov}

\begin{tabular}{|c|c|c|c|c|c|}
\hline \multicolumn{6}{|l|}{ ROA (\%) } \\
\hline Elektrodistribucijske družbe & 2012 & 2013 & 2014 & $\begin{array}{c}\text { Povprečna } \\
\text { vrednost } \\
2012-2014 \\
\end{array}$ & Rang \\
\hline $\mathrm{A}$ & 2,9 & 2,1 & 3,4 & 2,80 & 5 \\
\hline B & 1,3 & 1,6 & 2,3 & 1,73 & 1 \\
\hline $\mathrm{C}$ & 1,1 & 1,8 & 2,6 & 1,83 & 3 \\
\hline $\mathrm{D}$ & 2,1 & 2,3 & 2,8 & 2,41 & 4 \\
\hline $\mathrm{E}$ & 1,6 & 2,2 & 1,5 & 1,77 & 2 \\
\hline \multicolumn{6}{|l|}{ ROE (\%) } \\
\hline Elektrodistribucijske družbe & 2012 & 2013 & 2014 & $\begin{array}{c}\text { Povprečna } \\
\text { vrednost } \\
2012-2014\end{array}$ & Rang \\
\hline A & 4,2 & 3,1 & 4,8 & 4,03 & 5 \\
\hline B & 1,9 & 2,3 & 3,4 & 2,53 & 2 \\
\hline $\mathrm{C}$ & 1,9 & 3 & 4,3 & 3,07 & 3 \\
\hline $\mathrm{D}$ & 3,0 & 3,1 & 3,8 & 3,29 & 4 \\
\hline $\mathrm{E}$ & 2,2 & 3,1 & 2,1 & 2,47 & 1 \\
\hline \multicolumn{6}{|c|}{ Koeficient gospodarnosti poslovanja } \\
\hline Elektrodistribucijske družbe & 2012 & 2013 & 2014 & $\begin{array}{c}\text { Povprečna } \\
\text { vrednost } \\
2012-2014 \\
\end{array}$ & Rang \\
\hline A & 1,118 & 1,126 & 1,156 & 1,13 & 4 \\
\hline B & 1,129 & 1,158 & 1,187 & 1,16 & 5 \\
\hline $\mathrm{C}$ & 1,086 & 1,138 & 1,18 & 1,13 & 4 \\
\hline $\mathrm{D}$ & 1,11 & 1,12 & 1,16 & 1,13 & 4 \\
\hline $\mathrm{E}$ & 1,091 & 1,13 & 1,157 & 1,13 & 4 \\
\hline \multicolumn{6}{|c|}{ Dodana vrednost na zaposlenega (EUR) } \\
\hline Elektrodistribucijske družbe & 2012 & 2013 & 2014 & $\begin{array}{c}\text { Povprečna } \\
\text { vrednost } \\
2012-2014 \\
\end{array}$ & Rang \\
\hline A & 69.412 & 73.331 & 77.077 & 73.273 & 3 \\
\hline $\mathrm{B}$ & 83.437 & 87.777 & 90.322 & 87.179 & 5 \\
\hline $\mathrm{C}$ & 67.693 & 78.279 & 83.561 & 76.511 & 4 \\
\hline D & 66.803 & 68.247 & 69.768 & 68.273 & 2 \\
\hline $\mathrm{E}$ & 62.363 & 67.683 & 65.753 & 65.267 & 1 \\
\hline
\end{tabular}


Poslovni prihodki na zaposlenega (EUR)

\begin{tabular}{|l|r|r|r|r|r|}
\hline & & & & $\begin{array}{c}\text { Povprečna } \\
\text { vrednost }\end{array}$ & \\
\hline Elektrodistribucijske družbe & 2012 & 2013 & 2014 & $2012-2014$ & Rang \\
\hline A & 106.686 & 108.909 & 105.452 & 107.015 & 3 \\
\hline B & 121.932 & 128.590 & 131.306 & 127.276 & 5 \\
\hline C & 109.935 & 115.969 & 123.466 & 116.457 & 4 \\
\hline D & 97.086 & 100.505 & 97.545 & 98.379 & 1 \\
\hline E & 99.426 & 102.644 & 101.711 & 101.261 & 2 \\
\hline
\end{tabular}

Čisti dobiček na zaposlenega (EUR)

\begin{tabular}{|l|r|r|r|r|r|}
\hline & & & & $\begin{array}{c}\text { Povprečna } \\
\text { vrednost }\end{array}$ & \\
\hline Elektrodistribucijske družbe & \multicolumn{1}{|c|}{2012} & 2013 & 2014 & $2012-2014$ & Rang \\
\hline A & 11.716 & 8.747 & 12.889 & 11.117 & 4 \\
\hline B & 9.186 & 11.226 & 16.279 & 12.230 & 5 \\
\hline C & 5.778 & 9.321 & 13.479 & 9.526 & 2 \\
\hline D & 8.949 & 9.562 & 11.188 & 9.900 & 3 \\
\hline E & 6.023 & 8.794 & 5.911 & 6.909 & 1 \\
\hline & & & & & \\
\hline SAIDI - nenačrtovane dolgotrajne prekinitve, lastni vzroki (min/uporabnika) & \\
\hline & & & & Povprečna & \\
& & & & vrednost & \\
\hline Elektrodistribucijske družbe & 2012 & 2013 & 2014 & $2012-2014$ & Rang \\
\hline A & 44 & 37 & 30 & 37,00 & 4 \\
\hline B & 15 & 24 & 17 & 18,67 & 5 \\
\hline C & 58 & 50 & 44 & 50,67 & 3 \\
\hline D & 53 & 50 & 77 & 60,00 & 2 \\
\hline E & 60 & 63 & 101 & 74,67 & 1 \\
\hline
\end{tabular}

SAIFI - nenačrtovane dolgotrajne prekinitve, lastni vzroki (prekinitev/uporabnika)

\begin{tabular}{|c|c|c|c|c|c|}
\hline Elektrodistribucijske družbe & 2012 & 2013 & 2014 & $\begin{array}{c}\text { Povprečna } \\
\text { vrednost } \\
2012-2014\end{array}$ & Rang \\
\hline A & 1,1 & 0,9 & 0,8 & 0,93 & 4 \\
\hline B & 0,6 & 0,9 & 0,5 & 0,67 & 5 \\
\hline $\mathrm{C}$ & 1,3 & 0,9 & 0,9 & 1,03 & 3 \\
\hline $\mathrm{D}$ & 2,1 & 1,7 & 2,6 & 2,13 & 1 \\
\hline $\mathrm{E}$ & 1,4 & 1,3 & 2,4 & 1,70 & 2 \\
\hline
\end{tabular}


Primerjava poslovne uspešnosti in procesne usmerjenosti

\begin{tabular}{|c|c|c|c|c|c|c|c|c|c|c|}
\hline \multirow[b]{2}{*}{ Elektrodistribucijske družbe } & \multicolumn{8}{|c|}{ Rang rezultatov } & \multirow[b]{2}{*}{$\begin{array}{c}\text { Povprečna } \\
\text { vrednost } \\
\text { rangov }\end{array}$} & \multirow[b]{2}{*}{$\begin{array}{c}\text { Povprečna } \\
\text { vrednost } \\
\text { procesne } \\
\text { usmerjenosti }\end{array}$} \\
\hline & $\underset{\approx}{\mathscr{\mho}}$ & 崩 & 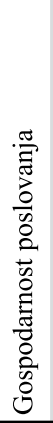 & 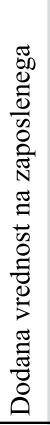 & 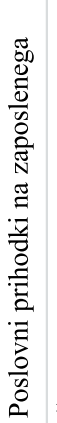 & 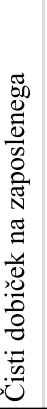 & 客 & 至 & & \\
\hline $\bar{A}$ & 5 & 5 & 4 & 3 & 3 & 4 & 4 & 4 & 4,00 & 5,19 \\
\hline B & 1 & 2 & 5 & 5 & 5 & 5 & 5 & 5 & 4,13 & 5,49 \\
\hline $\mathrm{C}$ & 3 & 3 & 4 & 4 & 4 & 2 & 3 & 3 & 3,25 & 4,91 \\
\hline $\mathrm{D}$ & 4 & 4 & 4 & 2 & 1 & 3 & 2 & 1 & 2,63 & 4,57 \\
\hline $\mathrm{E}$ & 2 & 1 & 4 & 1 & 2 & 1 & 1 & 2 & 1,75 & 4,41 \\
\hline & & & & & & & & & & \\
\hline & & & & & & & & & & \\
\hline & & & & & & & & & & \\
\hline & & & & & & & & & & \\
\hline Elektrodistribucijske družbe & & $\begin{array}{l}\text { vpreč } \\
\text { ednos } \\
\text { angov } \\
\end{array}$ & $\begin{array}{l}\text { čna } \\
\text { ost } \\
\mathrm{V}\end{array}$ & & $\begin{array}{l}\text { vprec } \\
\text { edno } \\
\text { oces } \\
\text { erjen }\end{array}$ & $\begin{array}{l}\text { ična } \\
\text { ost } \\
\text { sne } \\
\text { nosti }\end{array}$ & & & & \\
\hline $\bar{B}$ & & & 4,13 & & & 5,49 & & & & \\
\hline A & & & 4,00 & & & 5,19 & & & & \\
\hline $\mathrm{C}$ & & & 3,25 & & & 4,91 & & & & \\
\hline $\mathrm{D}$ & & & 2,63 & & & 4,57 & & & & \\
\hline $\mathrm{E}$ & & & 1,75 & & & 4,41 & & & & \\
\hline
\end{tabular}





\section{Recenziji}

Znanstvena monografija, Merjenje zrelosti procesne usmerjenosti se osredotoča na ugotavljanje ravni zrelosti procesne usmerjenosti in prepoznavanje priložnosti za nadaljnje uveljavljanje procesnega delovanja organizacij slovenske elektroenergetske verige v podporo uspešnemu uresničevanju njihovih strategij. Ugotovitve raziskave imajo bistveno aplikativno vrednost, saj neposredno podpirajo sistematično oblikovanje, razvoj in nenehne izboljšave sistema poslovanja podjetja.

Monografija bralcem omogoča celovit vpogled v razvoj konceptov procesov, procesne usmerjenosti in managementa poslovnih procesov. Čeprav praksa potrjuje uporabnost zrelostnih modelov za nenehno izboljševanje managementa poslovnih procesov in procesne usmerjenosti, pa še ni celovite primerjalne študije $\mathrm{z}$ vidika koristnosti njihove uporabe pri povečevanju uspešnosti procesov in poslovne uspešnosti organizacij.

Tako je predstavljena raziskava prva, ki predstavlja zrelost procesne usmerjenosti v slovenski elektroenergetski industriji ( 9 organizacij). Eden od pomembnih razlogov za opravljanje meritev zrelosti v elektroenergetski industriji je pomen te dejavnosti za delovanje in razvoj celotne slovenske družbe. Rezultati merjenja zrelosti procesne usmerjenosti v elektroenergetski dejavnosti kažejo, da ta kljub dolgoletnemu ukvarjanju s procesi, uvajanju procesnega pristopa, certificiranim sistemom vodenja in informatizaciji poslovanja, ni visoka.

Merjenje je bilo izvedeno z rabo vprašalnika za razširjen koncept procesne usmerjenosti z devetimi elementi. Glede na statistično ovrednotene elemente procesne usmerjenosti se elektroenergetska dejavnost nahaja na 
drugi stopnji McCormackovega zrelostnega modela. Za to stopnjo (Definirano) je značilno, da so procesi opredeljeni in dokumentirani. Spremembe procesov potekajo na osnovi formalnih postopkov. Delovna mesta in organizacijske strukture že vključujejo procesni vidik, dejansko pa ostajajo funkcijske.

Analiza rezultatov opozarja na potrebo po boljšem komuniciranju z zaposlenimi. Med najnižje ali nizko ocenjenimi trditvami v posameznih elementih so trditve glede seznanjenosti zaposlenih s strateškimi cilji, z rezultati kazalnikov in doseganjem ciljnih vrednosti procesov ter predvidenimi spremembami. Elektroenergetska dejavnost je izrazito tehnična dejavnost, v kateri tudi med managerji prevladuje tehnični kader. $S$ predstavitvijo rezultatov in ugotovitev meritve zrelosti procesne usmerjenosti v izbrani dejavnosti omogoča bralcem uvid $\mathrm{k}$ koristnost merjenja in uporabe zrelostnih model za razvoj posameznih sposobnosti in zrelosti procesne usmerjenosti organizacije $\mathrm{v}$ podporo uspešnemu uresničevanju strategij in trajnostno uspešnemu razvoju.

Boris Bukovec

II

Znanstvena monografija se ukvarja z merjenjem nivoja zrelosti procesne usmerjenosti slovenske elektroenergetske verige. Obenem avtorja skušata najti priložnosti za uveljavljanje procesnega delovanja teh organizacij. V monografiji je obravnavan strateški vidik razvoja elektroenergetske verige v smislu izboljševanja ekonomsko tehničnega sistema, trajnostnega razvoja in posledično zahtevanih organizacijskih sprememb.

Kljub dejstvu, da številni raziskovalci priznavajo pomen procesne usmerjenosti za poslovno uspešnost organizacij, pa še vedno ni celovitih raziskav, ki bi nedvoumno potrjevale pozitivno korelacijo procesne usmerjenosti in uspešnosti poslovanja. Praksa številnih organizacij potrjuje uporabnost zrelostnih modelov za nenehno izboljševanje managementa poslovnih procesov in procesne usmerjenosti, kljub temu pa še ni celovite primerjalne študije $\mathrm{z}$ vidika koristnosti njihove uporabe pri povečevanju uspešnosti samih procesov in poslovne uspešnosti organizacij.

Predstavljena raziskava zato predstavlja noviteto na tem področju. Raziskava obravnava zrelost procesne usmerjenosti v slovenski elektroenergetski industriji. Rezultati merjenja kažejo, da ta kljub dolgoletnemu ukvarjanju s procesi, uvajanju procesnega pristopa, certificiranim sistemom vodenja in informatizaciji poslovanja, zrelost procesne usmerjenosti ni visoka. 
Raziskava je bila izvedena $\mathrm{z}$ vprašalnikom za razširjen koncept procesne usmerjenosti z devetimi elementi. Glede na statistično ovrednotene elemente procesne usmerjenosti se elektroenergetska industrija nahaja na drugi stopnji McCormackovega zrelostnega modela. To pomeni, da so procesi definirani in dokumentirani, zagotovljena je ponovljivost in sledljivost, njihovo spreminjanje pa je standardizirano.

Relativno nizko so ocenjeni elementi seznanjenosti zaposlenih s strateškimi cilji, z rezultati kazalnikov in doseganjem ciljnih vrednosti procesov ter predvidenimi spremembami. Najslabše ocenjeni elementi pa so informacijska tehnologija, upravljanje z zaposlenimi in vidik dobaviteljev.

Zaključimo lahko, da je elektroenergetska dejavnost izrazito tehnična dejavnost, v kateri tudi med managerji prevladuje tehnični kader. Zato ugotovitve raziskave predstavljajo dragoceno povratno informacijo najvišjemu managementu o nujnosti razvoja mehkih veščin pri delu z zaposlenimi, razvoju zaposlenih, o pomembnosti razvoja procesne organizacijske kulture in procesne organizacijske strukture.

Tomaž Kern 


8

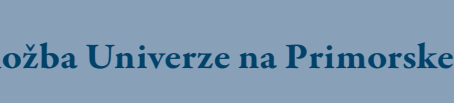

